Historic, Archive Document

Do not assume content reflects current scientific knowledge, policies, or practices. 

C2.

1928

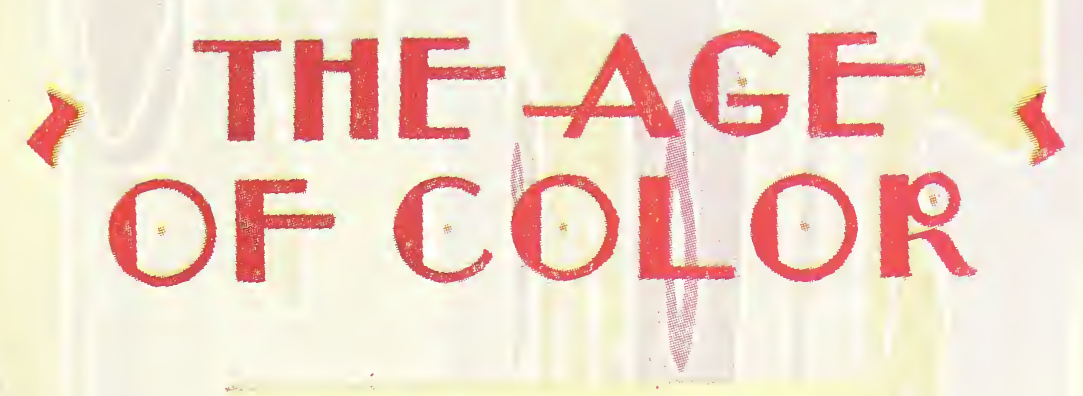

ADPR VED.PEONIES/

INDIAN SDRING FARXY.

- HEORDORATED.

AI WWINRILIE. NEW TORK 
Copyright, 1928

INDIAN SPRING FARMS, INC. 


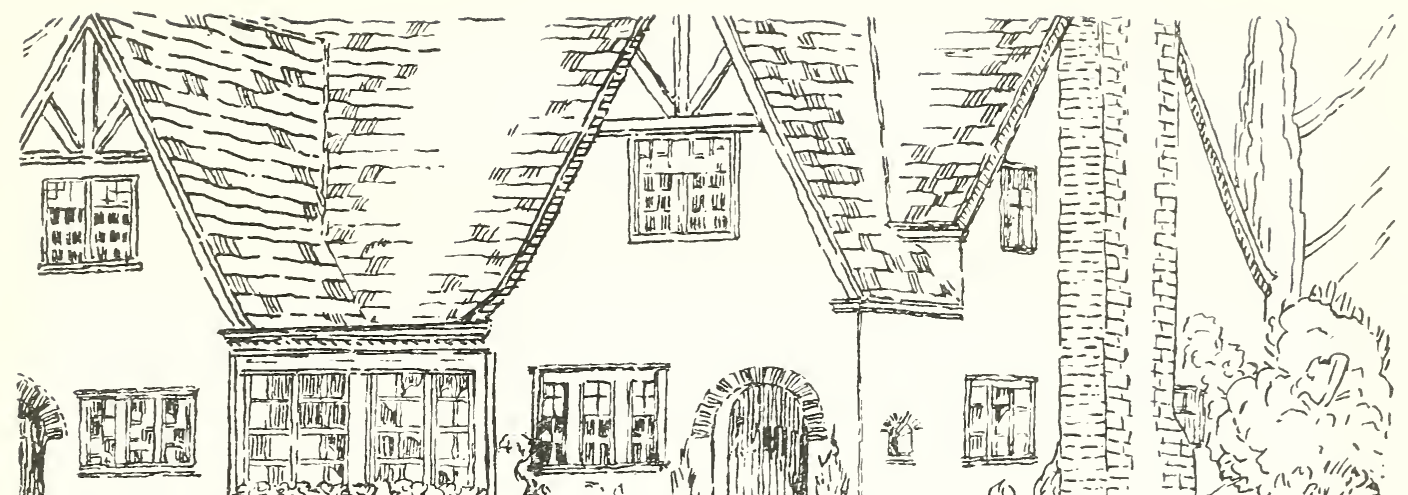

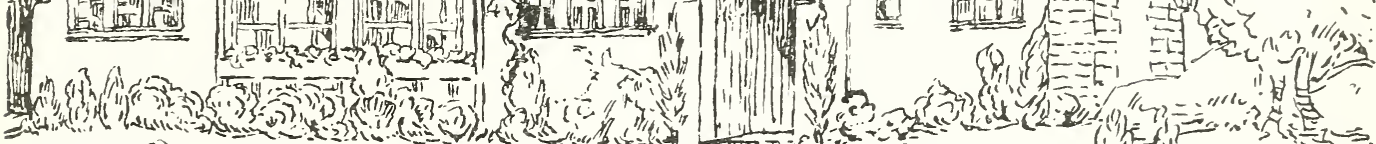

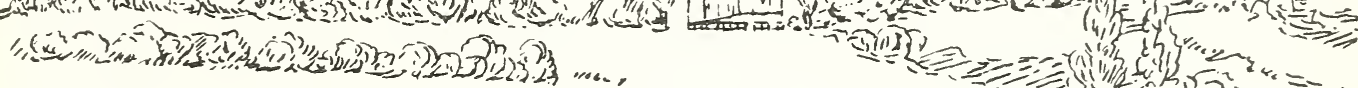
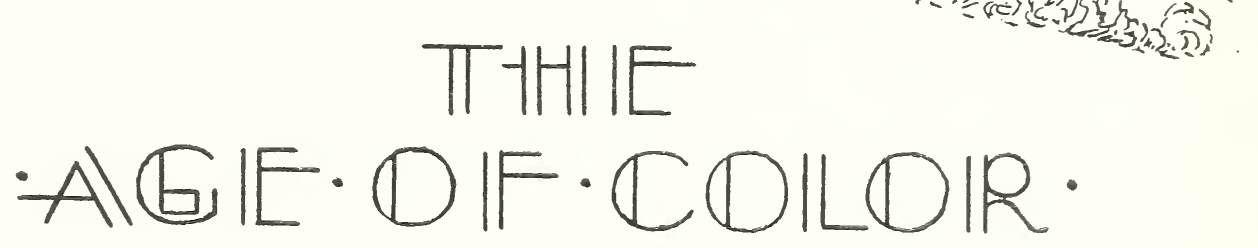

\begin{tabular}{l|} 
We bring to your \\
garden and land. \\
scaping a profusion \\
of floral colors and \\
the fragrance of \\
our fields \\
(0)
\end{tabular}$\|$

INDIAN SPRING FARMS, INC. BALDWINSVILLE, N. Y.

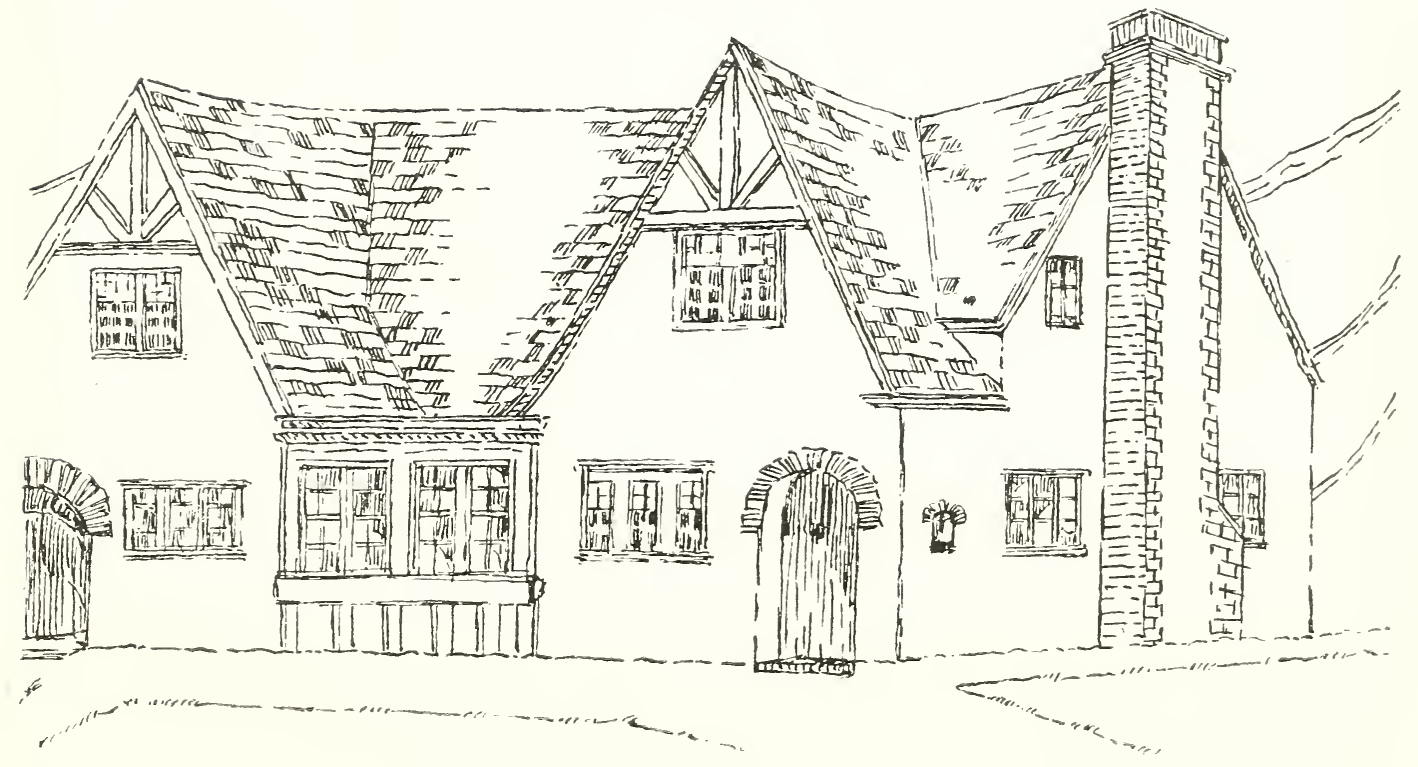




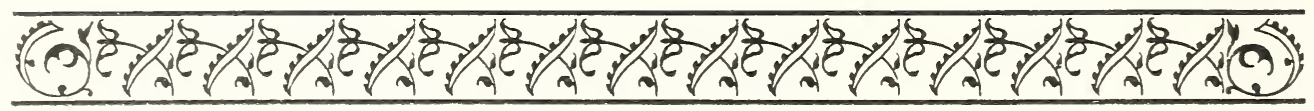

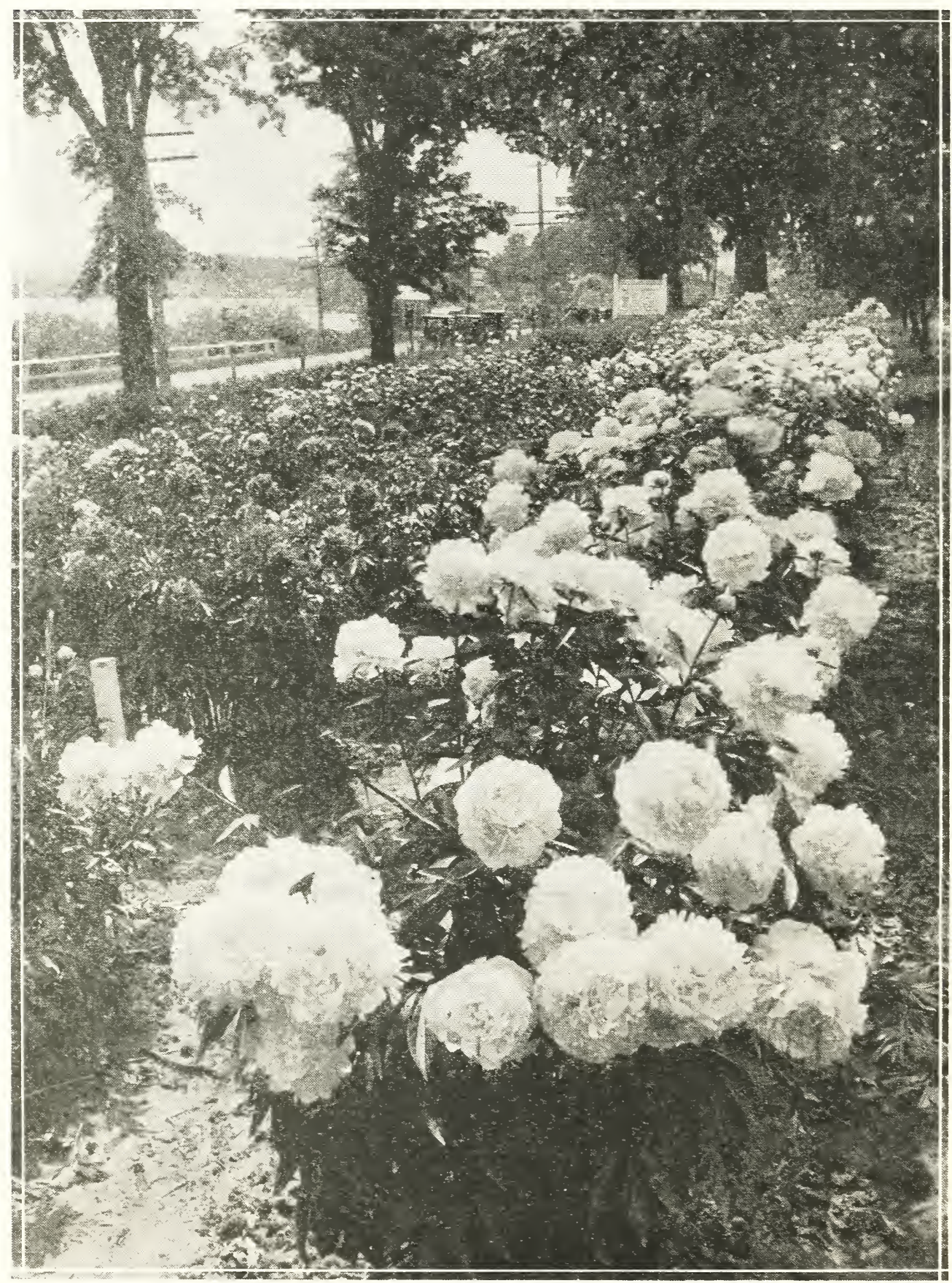

\section{$\llbracket\left[\begin{array}{c}\text { MME. } \\ \text { De VERNEVILLE } \\ \text { A desirable white that } \\ \text { furnishes an abundance }\end{array}\right]$




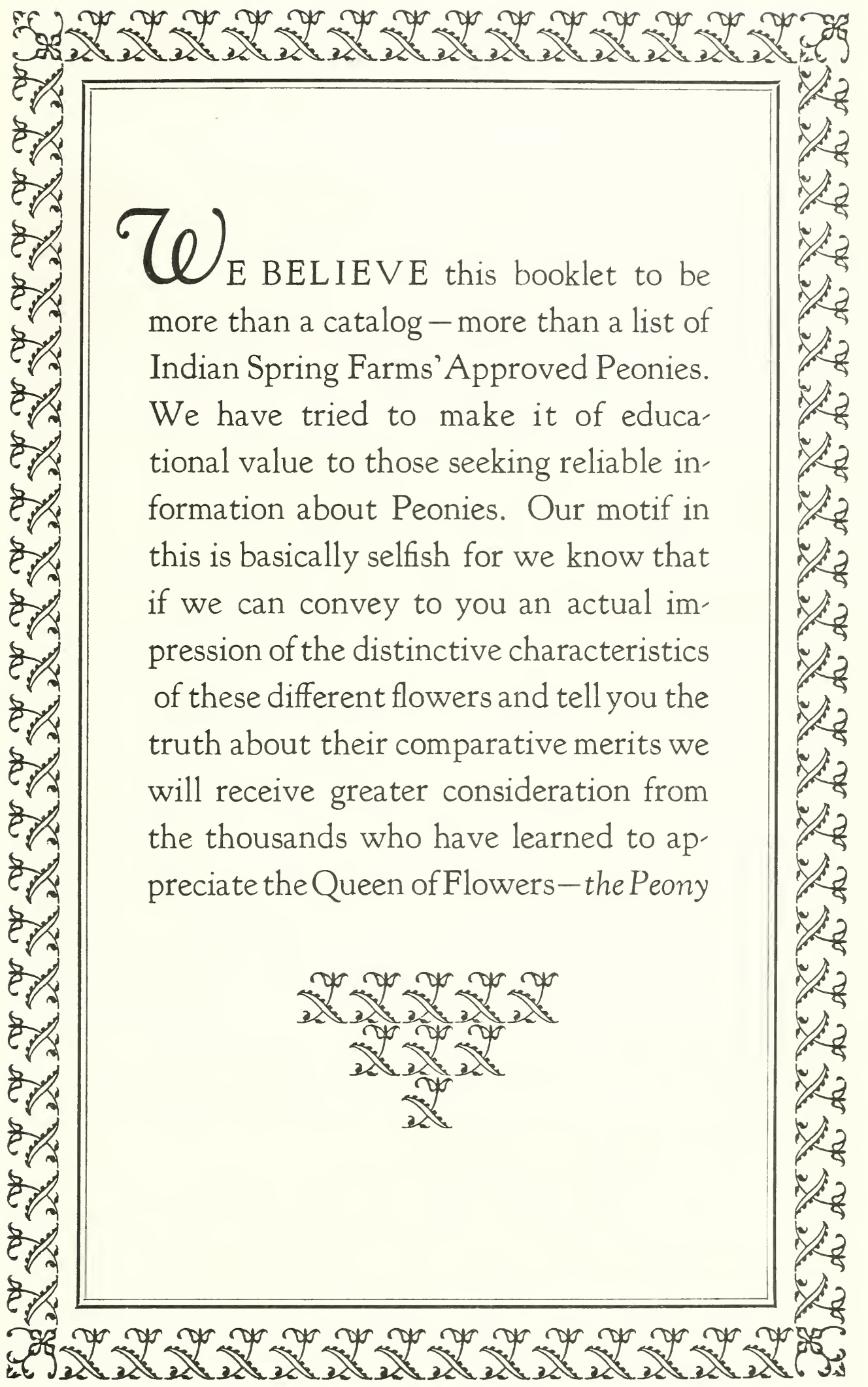



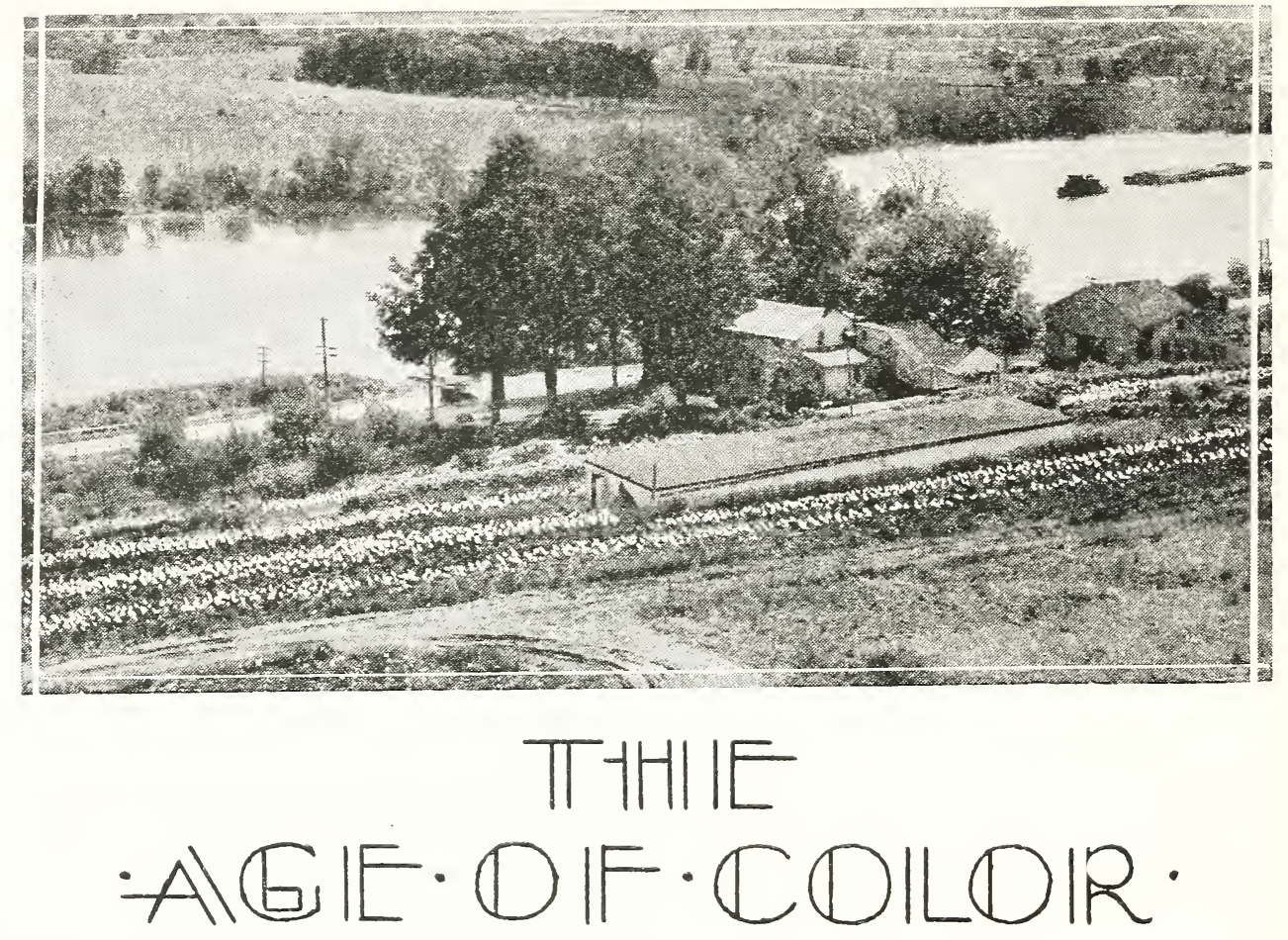

CUDDENLY all America has become color conscious. Red motor cars vie with striped ties for man's favor while cook stoves of vivid hue fight with gaily designed shoes for first esteem in woman's eye. But it is about the home, the garden, the yard, this newly awakened knowledge more forcefully presents itself. Gone are the long bare expanses of green grass from which formerly towered stolid, bare house foundations. Now the modest cottage and the palatial residence, alike, rest in frames of gaily colored flowers. Vines and rose bushes climb artistically planned trellises while motor drives and wide walks porches and alcove windows form backgrounds for many-hued flowers.

Hard, strict regularity in ground layout and in yard planning has given way to nonchalant irregularity. Master and mistress, alike, have learned the secret of the artistically enveloped homes.

So developed has become this feeling that when, in a moment's repose, the cliff-dwelling city worker pictures his retreat of old age, it invariably becomes either a little vine covered cottage in the country or a stately mansion in a suburb. And in either case, he considers neither of these pictures unless the cottage or mansion is bordered by, and set in its frame of flowers with gaily hued plants in their nests of green acting as facets for his home.

When the Sunday motor ride through the country has been completed, some comment will be made by someone in the family of some beautiful home, stately or unpretentious, that has made its mark on the tourist's eye because of its floral setting.

Color in flowers, paint and arrangement can be said to have become dominating things in home attention value. In every community there exists a realtor who has learned this to his own financial benefit. You without doubt will be able to recall in your own section an instance such as this, when a little time, a small amount of money and a great amount of green grass and flowers brought a handsome increment in value.

So every home regardless of its financial worth or its architecture can be made more beautiful through the use and the arrangement of flowers. And this gift of nature - these bright colors and these pleasing floral combinations have become available to everyone for their delight and benefit. 


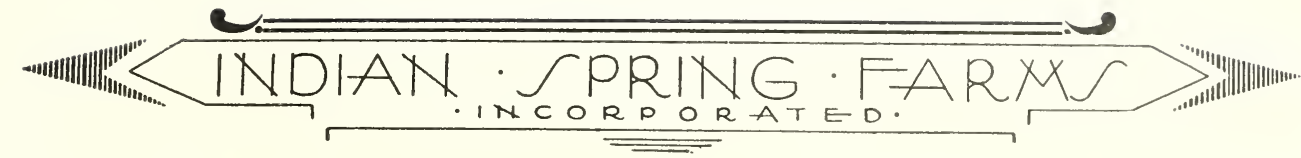

\section{The Flower of the North-the Peony}

$I^{\prime}$ TERESTING, indeed, is the Mythological origin of the Peony. When Hercules, the son of Jove, wounded Pluto during the Trojan war by piercing him with a swift shaft through his huge shoulder, Pluto sought relief from the grievous pain that tortured his soul at the palace of Jove on lofty Mt. Olympus. There wise Paeon, physician of the gods, who had been a pupil under Aesculapius, god of medicine, was called. Thereupon, Paeon called in consultation Apollo, the great god of healing, who was the father of Aesculapius. Apollo, in turn, made intercession with his worthy parents, Zeus and Leto, with the result that Paeon received the first Peony from the hands of Leto on Mt. Olympus. With this pain-assuaging herb he healed the wound of Pluto. This cure caused much jealousy in the breast of Aesculapius and he plotted the death of Paeon. Pluto, however, in great gratitude for what Paeon had done, determined to save him from the fate of mortals and changed him into the living plant that had effected the cure-the Paeonia. Even down to the present this name has endured, and the Officinalis species, found native to southern Europe, is still highly regarded for its medicinal properties.

Of greater interest at the present time is another herbaceous species, $\mathrm{P}$. albiflora, known as the Chinese Peony. It is from this primitive type, found native in the rigorous climate of northern China and Siberia, that the Modern Chinensis Peony varieties have been developed.

So remarkable have been the results accomplished through years of steadfast devotion and untiring effort on the part of the Peony lovers and hybridizers that today the modern Peony is the most superb and outstanding flower that grows in our gardens. In size of bloom and gorgeous color display it has no rival. The iris, the lily, the dahlia and even the rose, as beautiful as it is with its perfection of form and its delightful fragrance, must yield first place to the wonderful coloring and regal splendor of the Peony, which Mrs. Edward Harding in her delightful book has titled the Queen of Flowers.

The fascinating charm of the Peony is enhanced by the wide variation in form of the flowers as well as by their grace and beauty. Starting with the true single form of the primitive species, miracles of transformation have been performed until traces of the elementary stamens, anthers, carpels and stigmas have disappeared and in their stead are perfect petals of delicate texture and enduring substance that make up full double flowers which in symmetry and refinement have no equal. The present list of Peony varieties includes flowers in various stages of this process of development and affords an interesting range of more or less definitely fixed types, which for descriptive purposes have been designated as Japanese, anemone, bomb, semi-double, crown, semi-rose, and rose forms.

In all these different forms a varied color range is afforded. From purest white, the shadings vary through almost innumerable tints of pink, rose and carmine to crimson and darkest red. Certain flowers show hues of silver, lilac and lavender, and many have petals of yellow, or reflect tints of gold, as a remainder of the yellow stamens that once were present. While hybridizers have long been striving to produce a yellow Peony and have approximated their ambitions in such fine flowers as Primevere, Laura Dessert and Golden Dawn, which open a distinct shade of canary yellow and slowly shade to a white, there is yet no true yellow Peony of fixed color.

The modern Peony, being born of rugged parentage, is perfectly hardy and will thrive in the coldest climates without winter protection. It may be grown successfully wherever the ground freezes during any part of the winter, and is at its best in the colder regions where most perennials find it hard to endure. Because of its hardiness the Peony is the ideal Flower of the North. For the 


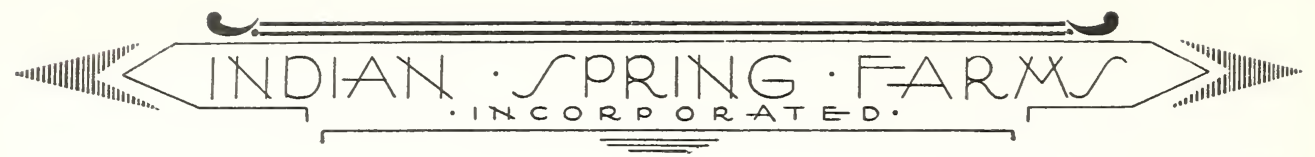

colder sections of the United States-the New England States, New York, the Great Lakes region, the Northwest-and for Canada, it is the most satisfactory outdoor plant, and it is being more widely exploited and planted each season. The Peony is not at home in tropical climates and cannot be grown successfully in Florida or in California south of San Francisco.

\section{Landscape with Peonies}

CS Peony growers, the possibilities of the use of Peonies in landscape design has been forcibly impressed upon us. Of all hardy perennials, the Peony seems best adapted to landscape use. It is a plant of interest and beauty from the day its first shoots appear above the ground in spring until severe freezes lay it low in the fall. Beginning in the early spring, its rapid growth and development effect a constantly changing panorama of Nature's wonders.

Even before the sun can drive away the chills of winter, the Peony breaks through the crust of the earth with a force so strong as often to actually raise up any clods of earth that block the way. The finger-like shoots, varying in color from deepest red through shades of pink and rose to livid green, lengthen out so rapidly that one can almost see them grow. The developing foliage, drawn up loosely about the stems, appears like mysteriously twirled and twisted brushes of mop-like form. These quickly unfold into interesting treelike stems with leaves, sometimes wide and sometimes narrow, attractively colored. Topping each stem a flower-bud is disclosed, already well developed and ready to go. Immediately the bud-stems begin to lengthen and the everenlarging buds are lifted from their nesting places well down in the foliage, until they stand on long, straight stems well above the topmost leaves. Almost before the change can be realized, the tender-appearing colored foliage becomes a vigorous, healthy green, and a well-proportioned, bushy plant stands two to four feet tall, ready to break forth into bloom.

What a glorious plant a well-grown Peony in full bloom is! Its flowers are the largest of all the perennials, and the different varieties afford a range of delicate beauty and gorgeous colorings scarcely equaled in any other flower. For over a week its marvelous flower display holds on.

But the blooming time is not the end of the Peony beauty. When the last petals have fallen, the flower-stems may be pruned back, and there remains a robust and healthy green plant that is attractive throughout the summer and until the first frost again works wonders with the foliage. The dull autumn shades of the fall range from bronzes through the yellows to deepest reds in richness not surpassed by any other plant or tree.

Such is the life of a Peony. Not a day in its history is the plant unsightly or displeasing. Of what other perennial can as much be said?

Unfortunately, all Peonies are not equally adapted to landscape use. The varieties vary much in their habits and growth. Some of the most beautiful show flowers grow on plants of spreading habit; others are produced on weak stems that cannot support the heavy blooms. Likewise there are varieties that open up blooms of delicate beauty, but fade quickly and finish badly. They should not be used for landscape effect.

There are, however, plenty of Peonies that are without faults. Their growth is strong and vigorous, the foliage is heavy and well placed, and they carry their blooms well, even through storm and wind. Such varieties we like to designate as Landscape Peonies.

We especially recommend for landscape uses the varieties designated in our descriptive list as Landscape Peonies. 


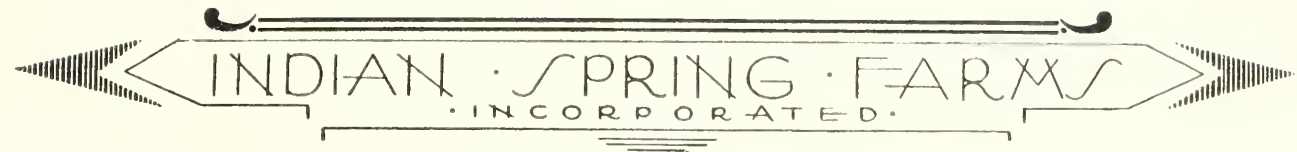

\section{About Approved Peonies}

y EARS of experience with Peonies have impressed upon us the fact that of the hundreds now in commerce, there are scores of varieties, some old and some new, that for one reason or another are not universally satisfactory for the average garden. On the other hand, there are certain varieties that are of outstanding merit and that are as thoroughly satisfactory to the amateur gardener in his first Peony planting as to the more skilled grower. The uninitiated buyer, selecting his first Peonies, is wholly at sea trying to choose from several hundred sorts by mere catalog descriptions, and often finds, after growing his plants for several years, that he has Peonies that never should have been planted in his garden.

While the rating of Peony varieties, as determined by the symposium of the American Peony Society, is a valuable guide to the merits of the different flowers, and is the best information available to the inexperienced grower, there are facts about these Peonies not expressible in rating figures. Good, healthy stock, free-blooming strains, reliability of blooming, and habits of growth-all are features that are important in successful Peony culture.

With these facts in mind, we have given careful consideration to each of the hundreds of varieties of Peonies we have grown, and have so built up what we choose to call our list of Approved Peonies, which is an important and permanent feature of this business.

First of all, an Approved Peony must be one that by actual personal experience we have found to be distinct and of outstanding merit. It must produce a beautiful flower, be a free and reliable bloomer, and have a plant of satisfactory habits. Further than that, it must be one of which we have good, healthy stock, of free-blooming strain, that has been grown to maturity and thoroughly tested out in our own plantings.

In thus presenting our Approved Peonies we do not presume to say that the list includes all the good kinds. It is not offered as a selection of "the best hundred" varieties, and it is not our list of the "highest rates" Peonies. It is, rather, our selection of varieties that actual personal experience has proven to us to be worth-while Peonies, and of which we have acquired and grown sufficient stocks of approved quality so that we can conscientiously recommend and sell them to our best friends with full assurance that e ch is a good Peony and one that they will always be proud to have growing in their gardens. It is not a limited list, but will be added to from time to time as new or untried varieties prove themselves in our gardens to be worthy of our recommendation.

We trust that this Approved Peony List will make a place for itself in the Peony world not yet filled by any other selection of varieties. It is offered as an exclusive list of tried and true "aristocrats" which we hope may establish a new standard of excellence for Peonies. It should be a valuable guide to amateurs in selecting their first Peonies, and should be looked up to as an objective by growers in trying to market new and unknown seedlings.

In the General Price List that follows, all Approved Peonies are underscored thus, ADOLPHE ROUSSEAU. 


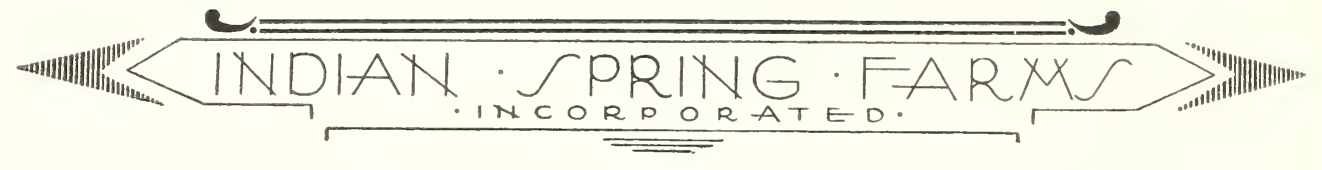

\title{
The American Peony Society
}

The American Peony Society is an organization of Peony growers, both amateur and commercial, who love the Peony and are interested in the betterment of the flower and the fostering of its growth.

Its greatest works have been the straightening out of the Peony nomenclature, through the combined efforts of its committees and the College of Agriculture of Cornell University at the test plantings at Ithaca, N. Y., and the compiling of ratings of hundreds of Peony varieties through symposiums of the votes of the entire membership of the Society, or of juries selected from its members.

These symposium ratings, compiled on a basis of 10 as a perfect flower, express in figures - thus, Avalanche 8.7-the average of the votes on the different varieties and reflect, in a fairly accurate way, the relative merits of the flowers. Such ratings have proved of great value to the Peony industry, and are the best guide for inexperienced buyers in selecting varieties.

In the following lists, the latest official rating of each variety is given next after the name of the originator. Where no rating is given, the variety has not yet been rated by the Society.

\section{Join the American Peony Society}

This is our invitation to you to become a member of the American Peony Society and by so doing help in the work of that organization in fostering the interests of this finest of all flowers. You will enjoy the Official Bulletins of the Society, which are issued several times during the year, and will feel in closer touch with the hundreds of members who love the Peony best.

Application for membership, accompanied by a check for $\$ 3.00$, the annual membership fee, made payable to the American Peony Society, may be sent to us or mailed direct to

\author{
W. W. COOK
}

Treasurer of the American Peony Society, Clinton, Ia.

\section{The New Peony Manual}

The American Peony Society has long been working toward the publication of a new and up-to-date manual of the Peony that would be a fair and accurate treatise of the flower and its culture in America. Much time and labor, as well as money, has been expended in obtaining accurate first hand descriptions of all the worthy peony varieties now in commerce, and especially of the newer introductions on which accurate data has never been available.

This book is now in the hands of the printers and will possibly be announced before this catalogue is distributed. We take this occasion to call attention to the valuable book and to recommend it to anyone who is at all interested in the Peony.

The manual will represent the combined efforts of many of the greatest Peony authorities, and is published solely in the interest of the Peony and not of any individual. In addition to the descriptions of varieties, it contains a complete check list of all the peony varieties now offered in commerce, interesting articles on different phases of Peony culture, and many new illustrations of the outstanding varieties, part of which are printed in color. 


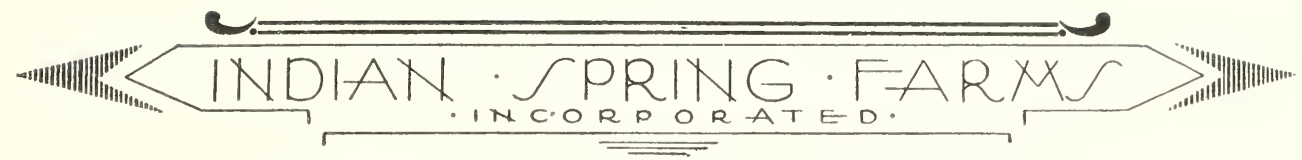

\section{Peonies for Spring Planting}

While Peonies are best planted in the fall because they begin their growth very early, they may be successfully planted in the spring, provided the roots have been dug in the fall and carried dormant in storage through the winter.

For the convenience of customers who find it desirable to make spring plantings, we carry limited stocks of our Approved Peonies in storage for spring sale and are prepared to make shipments as wanted up to May 1. Orders for spring shipments should be placed as early in advance as possible to insure getting all varieties wanted. When the rare and more expensive kinds are wanted, orders must reach us before the close of the fall digging so we can provide for them specially.

All roots in storage will be planted about May 1, and orders received after that time will be recorded for fall shipment unless we are otherwise instructed.

\section{Approved Peony Roots}

Experience has convinced us that the most satisfactory Peony root to plant is the strong natural division from a mature plant such as can be made with the least possible cutting. These natural divisions usually show two to five strong eyes and often have several smaller ones, and are always supported by a well balanced root system. This is the type of root recently adopted by the Commercial Peony and Iris Growers Association as the standard Peony division, and this is the type of root we have chosen to offer to our patrons.

Our years of experience have further taught us that it is not good practice to plant these natural Peony divisions as they are dug from the ground and cut from the parent plant, with the mass of old root growth and the new fibrous growth intact. Such a root planted as a whole will make a stronger showing the first year, but the old root growth, after it is once disturbed, is very slow to become reestablished, if indeed it ever does so. The future vigor of the plant is in proportion to the new root growth developed. For our own plantings, we prune back all the old roots severely and carefully remove the fibrous growth. To the uninitiated gardener, such a pruned root may appear to lack the supporting strength of the mass of roots, but a division so pruned forces new growth and in the end grows a stronger and more vigorous plant. We spend many hours in thus trimming up and properly preparing the Approved Peony roots that we ship to our customers.

\section{How to Grow Good Peonies}

Peonies are easy to grow and will do well in almost any location where they have any reasonable chance. They will thrive with less care and attention than most perennials, yet they are worthy of special care and will repay for special cultivation. Once planted, they will live for years, increasing in beauty and value from season to season. Because they are slow to become established and resent being disturbed, care should be taken that new plantings be suitably located and the planting properly done.

When to plant. Peonies are best planted in the fall after the new eyes for the following season's growth have formed on the roots. Growers begin fall shipping after the eyes are matured, usually about September 15, and planting may successfully be done any time before the ground freezes up for 


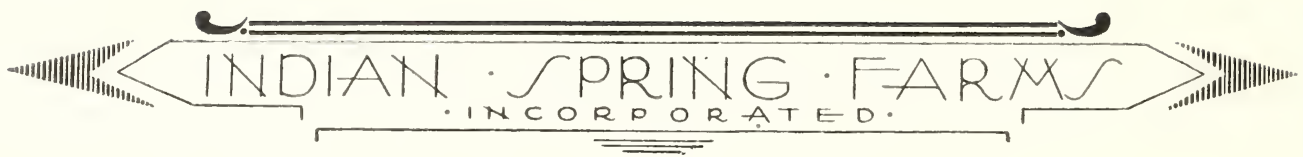

winter. Peonies also may be planted in the spring, if roots are obtainable that have been dug dormant in the fall and carried in storage during the winter. The earlier spring plantings are made the better. As peonies begin their spring growth very early, even before the snows of winter are gone, it is not advisable to dig roots in the spring.

What to plant. The first requisite in growing fine Peonies is to plant good varieties. Those who are not familiar with Peonies will find the ratings of the varieties, as accredited by the symposiums of the American Peony Society, a valuable guide to what kinds to plant. Our Approved Peonies, designated by the underscored names in our catalog lists, are the true Peony "aristocrats" selected after years of comparison and study, and are all varieties that we can conscientiously recommend as being among the best.

It is also important that good roots be planted. The best root to plant for quick and permanent results is a strong natural division from a mature plant that has bloomed satisfactorily. Divisions from young plants lack vigor, and a plant grown from such a root requires more time to regain its strength. Approved Peony roots are all divisions from mature plants.

Where to plant. Peonies should be planted in fertile, well-drained soil, and where they will get the full sun at least half the day. They will not do well in poorly drained ground, or where water stands about their roots during any part of the year; and they will not bloom well, if close under trees or in full shade. Never plant Peonies in soil where Peonies have been grown before.

In garden plantings, they are at their best in separate beds, and are ideal as individual plants, or in groupings, to give permanence to the borders, where they are of value for their attractive foliage effects throughout the summer, as well as for their display of blooms in season. In landscape use, they are admirable for bordering a path or drive, for use as a hedge, or for mass effects in front of shrubbery to give color accent to the vistas. They also work in to advantage in foundation plantings, if located where they are not deprived of the natural moisture or soil fertility.

Preparation of soil. Any good garden soil will grow good Peonies, but the more care that is given to preparing the ground where Peonies are to be planted, the better the blooms will be. For best results, the soil should be deeply prepared, $1 \mathrm{I} / 2$ feet at least, by spading under a compost mixture, or well-rotted stable manure, several weeks before the planting season. Under no circumstances should fresh manure be used around Peonies. If it is not practical to thus enrich the soil in advance, bonemeal may be scattered in the bottom of the hole and mixed with the top-soil at planting time-a good handful to each plant is plenty.

How to plant. Approved Peony roots come to you carefully prepared, with the old root-growth properly pruned back, ready to plant. If old Peony plants are to be moved, they should be washed free of all soil and divided into natural plant divisions of two to five eyes each, with the old root-growth severely pruned back. This induces new root-growth and results in strong, vigorous plants. Old plants, moved and replanted intact, are very slow to reestablish themselves, and often will not bloom normally again for several years.

Set the planting divisions in the prepared soil at a depth so that the new eyes, or buds, will not be over 2 inches below the surface of the ground after the loose soil and the roots have settled. Shallower planting, so the eyes are just covered and protected from the wind and sun, does no harm, but too deep 


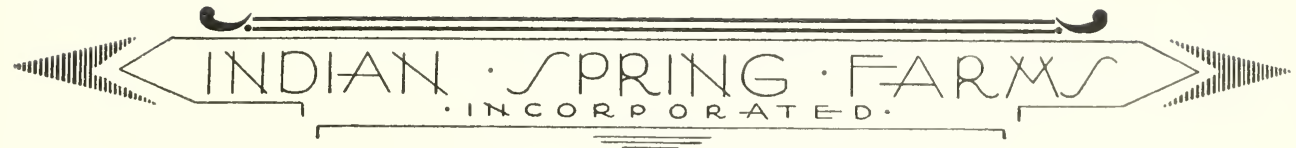

planting results in shy blooming, or no blooms at all. The loose earth should be worked in carefully around the roots and firmly packed to hold them in position. Watering is not necessary unless the ground be very dry, and then only to settle the soil about the roots. Late plantings should be covered with a light mulch of straw or leaves after the ground freezes to prevent the roots from being lifted by the frosts. This should be carefully removed in the spring before the new growth starts. For permanent plantings, Peonies should be at least 3 feet apart- 4 feet is better.

Cultivation. As soon as the new shoots are through the ground in the spring, the soil about the plants should be forked over to a depth of 3 or 4 inches to loosen up the top-soil. Frequent and thorough cultivation should be continued throughout the season, and especially after each rain, to keep down weed growth and to maintain a dust-mulch over the roots. Proper cultivation is the most important requisite in growing fine flowers.

How to water. In dry weather prior to the blooming season, watering the plants is very beneficial. Water is best supplied by removing the nozzle of the hose and allowing the water to run slowly about the base of the plants, until the ground is thoroughly soaked to a depth of at least $1 \mathrm{r} / 2 \mathrm{feet}$, each week or ten days. Mere sprinkling of the top-soil at frequent intervals does more harm than good. After each watering, cultivate to maintain the dust-mulch and hold the moisture.

Fertilizing. Peonies planted in prepared soil need no further fertilization for several years. While they are gross feeders, they are very susceptible to "indigestion," and they will not stand force-feeding. Rich fertilizers apparently may give wonderful results for a single season, but the plants will invariably show ill effects from their use the following year. Endeavor to keep Peony soil in good average fertility, but do not over fertilize.

After plants have grown three or four years in one place, they are benefitted by careful feeding. The best results will be obtained by forking under a light top-dressing of bonemeal about the plants each fall before the ground freezes. This will supply available nourishment when growth starts in the spring. Wood ashes in limited quantity, raked into the top-soil early in the spring, are also beneficial. Sheep manure may be safely scattered about the plants as they make their spring growth. Again let us caution, do not use fresh stable manure about Peonies.

Cutting flowers. In cutting your Peony blooms, remember that the foliage is the lungs of the plant. If you value your roots, always leave at least two leaves remaining on each stem for the support of the root. To obtain the finest cut-flowers, cut the buds just as the outer petals begin to loosen, and allow them to develop in water indoors.

After the flowering season. After the flowers have fallen, promptly prune all the bloom stalks back to the foliage, and shape up the plants. With their heavy, green foliage they will remain attractive throughout the summer and until the frosts cut them down in the fall. After the first severe freeze, cut off the tops close to the ground, and burn them or consign them to the compost pile. Do not leave them in the garden as a harbor for fungus diseases. Do not mulch your Peonies after the first winter. They do not require protection and will bloom all the better for being exposed to the rigors of winter. 


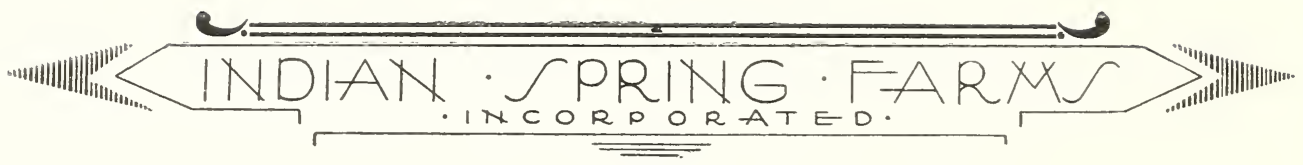

\section{Double Flowered Peonies}

For commercial convenience, all the varied types of Chinensis Peonies are commonly grouped into three more or less distinct classes-the Singles, the Japanese type and the Doubles.

In this Double Flowered list are included all semi-double and double varieties of the various types.

The underscored varieties comprise our Approved Peony List. See page 7.

ADDIELANCHAEA (Brand) 8.8. Large, full, rose-type flower, creamy white with a tint of yellow at the base of the center petals, the guard petals are prominently flecked with crimson and the center petals slightly so. Midseason. This is one of the older generation of Brand Peonies put out by Mr. O. M. Brand. At that time it was considered his best white. For several years it was lost from the Brand collection, but it is now being offered again though the stocks are limited. It is rated by those who are fortunate enough to have it as one of the really desirable Peonies.

$\$ 5.00$

ADELAIDE E. HOLLIS (Hollis 1907) 7.7. This beautiful Peony, as it grows with us, is worthy of a higher rating than it now carries. The flowers are large, high, crown type with the center petals broad and prominent, similar in shape to Venus. The color is uniform lilac-white, changing to almost pure white. The plant-growth is tall and upright with strong stems. Late midseason.

$\$ 3.00$

ADMIRAL TOGO (Hollis 1907) 7.1. A medium-sized flower of compact, flat, semi-rose type. The color is uniform dark crimson-carmine that does not fade or burn in the sun. The plant is medium tall, strong, erect and a free bloomer, with very dark green foliage, veined red. Midseason. $\$ \mathbf{1 . 0 0}$

ADOLPHE ROUSSEAU (Dessert \& Mechin 1890) 8.5. A very large, semidouble, rich dark red that blooms early. It is a tall and vigorous grower, and the flowers are produced on strong stems 4 feet in height. The foliage is a rich dark green, veined red. Even on old and well-established plants, the blooms vary in form from almost single to fuli double. This is one of the best early red varieties, and the healthy growth, together with the rich red color that does not fade, makes it very desirable for landscape use.

See "Backbone" Collection, page 84.

$\$ 1.50$

ALBATRE (Crousse 1885) 8.7. A very refined white Peony that has won its place among the "aristocrats." It is debatable whether this variety is identical with Avalanche. If not, they are so nearly alike that exacting critics cannot see the difference. The average garden has no need of both.

$\$ 1.00$

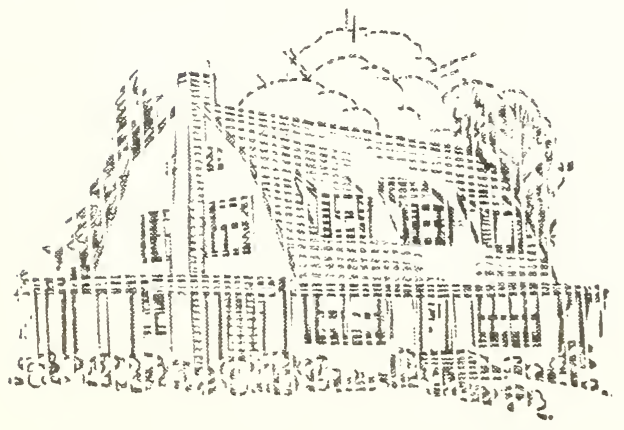

ALBERT CROUSSE (Crousse 1893) 8.6. Large, very full, convex blooms of soft shell-pink. The narrow, compact petalage is so symmetrically arranged that the flowers become very distinctively ball-shaped when fully open. A tall, erect plant that blooms freely near the end of the season and is desirable either for landscaping or 


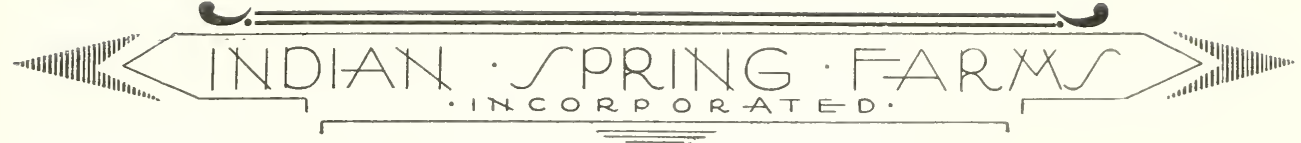

\section{ALBERT GROUSSE (continued)}

for cut-flowers. Fragrant. Certain Peonies have a distinctiveness in form and coloring that cannot be conveyed by words but which makes them stand out in our minds as really "finished" flowers, more beautiful and pleasing than other similar varieties. Albert Crousse is such a Peony.

$\$ 1.00$

ALEXANDRIANA (Calot 1856) 7.1. Very large, full, double, rose type flower of light violet-rose, shaded lighter at the tips of the petals. A strong, upright grower and free bloomer. Early. This is another of the older Peonies not rated high but with some outstanding qualities. While the blooms lack quality in texture, their immense size and pleasing form produced on a plant of desirable habit, make this a better landscape Peony than Monsieur Jules Elie.

$\$ 1.00$

ALEX D. VORIES (Vories 1924). Like the other Vories seedlings, this is a plant of strong, vigorous growth with long, upright stems. The flowers, a pleasing shade of American Beauty red that shades lighter at the edges of the petals, are very large, loose, semi-double, and are borne freely in midseason. A showy variety for landscape use and for those who admire color in quantity.

$\$ 5.00$

ALICE DE JULVECOURT (Pele 1857) 7.2. The flowers are of medium size, globular, crown type, produced freely on a dwarf plant of upright habits. The guards and center are lilac-white, prominently flecked crimson, the collar creamy white. There is a freshness and a fragrance to a newly opened bloom of Alice de Julvecourt that is particularly pleasing to those who know the variety well. Blooming in midseason, its charm is apt to be lost in the wealth of larger flowers in bloom at that time.

50 cts.

ALICE HARDING (Lemoine 1923). A beautiful new variety from France that M. Lemoine is said to regard as the finest peony he has ever introduced. The flower is very large, semi-double rose type, with a beautifully formed cupped center. The outer guard petals are broad and regular, tinted delicate flesh pink and flushed deeper carmine pink on the reverse; center petals are long and irregular with serrate tips, soft white with a creamy glow from the stamens irregularly scattered throughout the collar; center band petals minutely marked carmine. The plant is strong and vigorous with fine, clean foliage and strong, upright stems. Midseason. Blooms from two year plants show marked refinement in color and texture, and established plants will undoubtedly show all the quality that is claimed for the variety. On account of quarantine restrictions, available stocks are still limited.

$\$ 75.00$

ALFRED DE MUSSET (Crousse, 1885) 7.9. A nicely formed flower of large size and typical rose type. The color is flesh-white, with delicate salmon tints and a rose center, flecked crimson. A late variety that is better than its symposium rating indicates. Good healthy plants flower freely, and the blooms are particularly charming when handled as show flowers and opened indoors.

$\$ 1.00$

Of certain Peony varieties, especially some of French origin, a large per cent of the available stock in the country is infested more or less with the nematode disease, which causes.weak growth and shy blooming. This sick stock is responsible for the low ratings accredited to several varieties that would otherwise be classed much higher. 


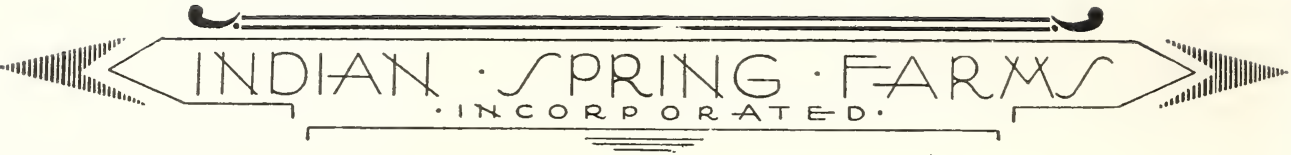

ALSAGE-LORRAINE (Lemoine 1906) 8.8. A late midseason variety that is distinct and beautiful. The flat, semi-rose type flower has petals that are long and slighily cupped at the ends and arranged to radiate symmetrically from the center like a water-lily. In color, it is a rich creamy white, delicately tinted brownish-yellow toward the center-a hint of the same color effect so greatly admired in Solange. The plant itself is attractive, vigorous in growth and free flowering, with the blooms carried gracefully on slender but strong stems that are well set with a distinctive brownish-green foliage. A fine variety that should have a place in every collection.

$\$ 2.00$

A. M. SLOCUM (Franklin 1920) 9.0. A loosely built flower of semi-rose type that is very attractive. White, with an occasional central petal slightly edged crimson, lighted up with a golden reflex from the yellow of the concealed stamens. A strong, upright grower and a free bloomer. The fact that the variety received a rating of 9.0 on the last symposium speaks more for its merits than does our description.

$\$ 7.50$

A. P. SAUNDERS (Thurlow 1919) 8.6. A variety of exceptional beauty. The very large, loose flowers are true rose type with scant rather than full petalage. The outer petals, long and curved, open first showing a large, loose, ball-shaped center that gives a magnolia-like form to the flower that is very beautiful. This center slowly unfolds its broad and somewhat irregular petals, making a wide-open bloom of dainty flesh-white that changes to nearly pure white. In growth, the plant is very tall and strong with broad green foliage. Late.

$\$ 10.00$

ARCHIE BRAND (Brand 1913) 7.5. A very large flower of an even, deep seashell-pink, with a silvery border. The closely massed petals form a true bomb-type bloom, square built and flat across the top, and with broad, drooping guard petals. A profuse midseason bloomer, highly fragrant. The pleasing fragrance and the soft, even coloring make this a desirable variety for cut blossoms. Flowers are heavy and should be planted in a clay soil without manure to grow the strongest possible stems.

$\$ 1.50$

ARLEQUIN (Dessert 1921) 8.1. An interesting variety that produces its flowers in variable forms and tints. On young plants and on the weaker stems, the blooms are of Japanese type, while mature plants and the vigorous stems produce full double flowers of crown shape. The broad guards are deep violet-rose, shaded lighter and splashed silvery white; collar and center lighter violet-rose, shading to salmon at the base of the petals, with a silvery reflex. The strong blooms are very beautiful. Midseason.

$\$ 3.00$

ASA GRAY (Crousse 1886) 8.1. A curiously colored flower that is always in great demand. It is large, semi-rose type, with guard petals salmonflesh and the center of the bloom symmetrically formed of broad petals; pale lilac color, thickly sprinkled with minute dots of deeper lavender. The general color effect is delicate lavender-pink. This desirable variety is almost universally described as a profuse and sure bloomer, but we have not found it to be so. With us it is wonderfully good some seasons, but it is not an extra-good grower. This must be true with others, too, because the stock is scarce, even though it has been introduced for many years.

$\$ 1.00$ 


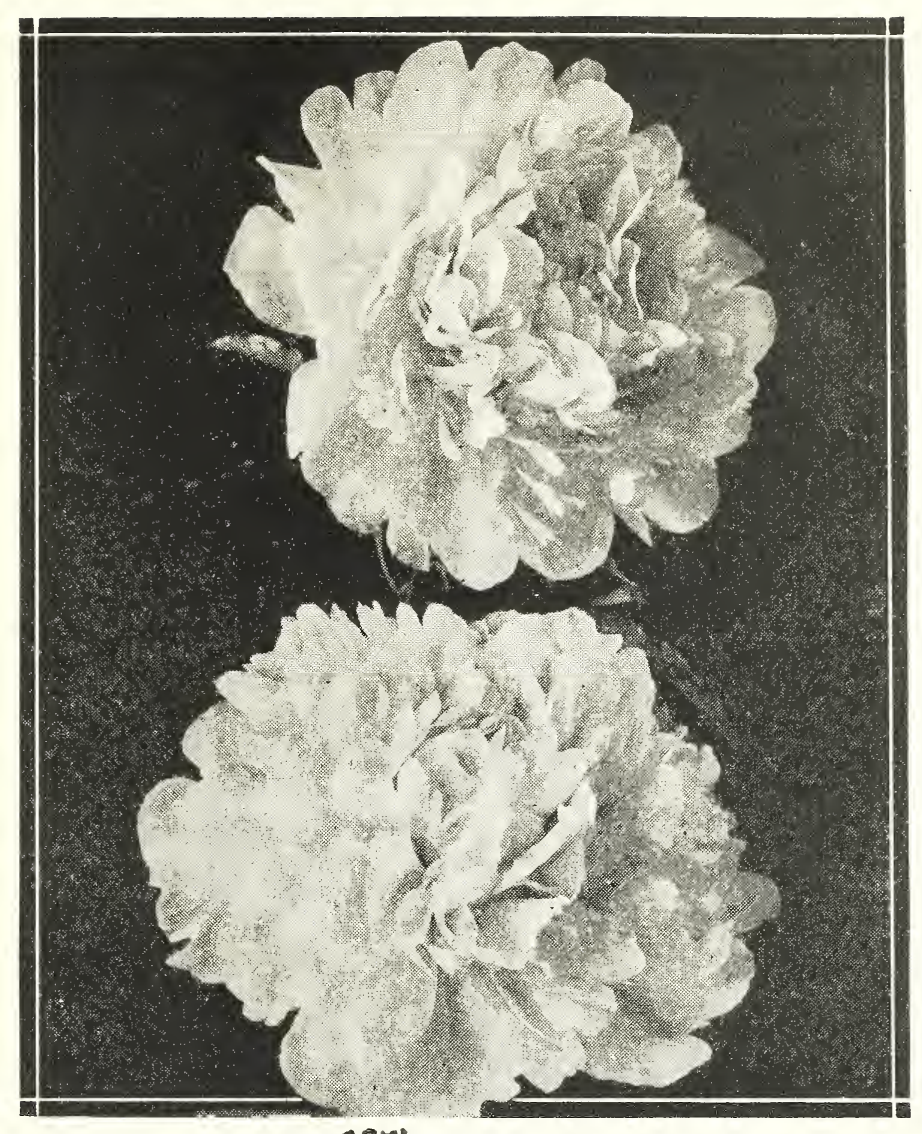

$\left\{\left[\begin{array}{c}\text { ALSACE LORRAINE } \\ \text { A graceful flower of dis- } \\ \text { tinctive character and re- } \\ \text { fined coloring }\end{array}\right]\right.$
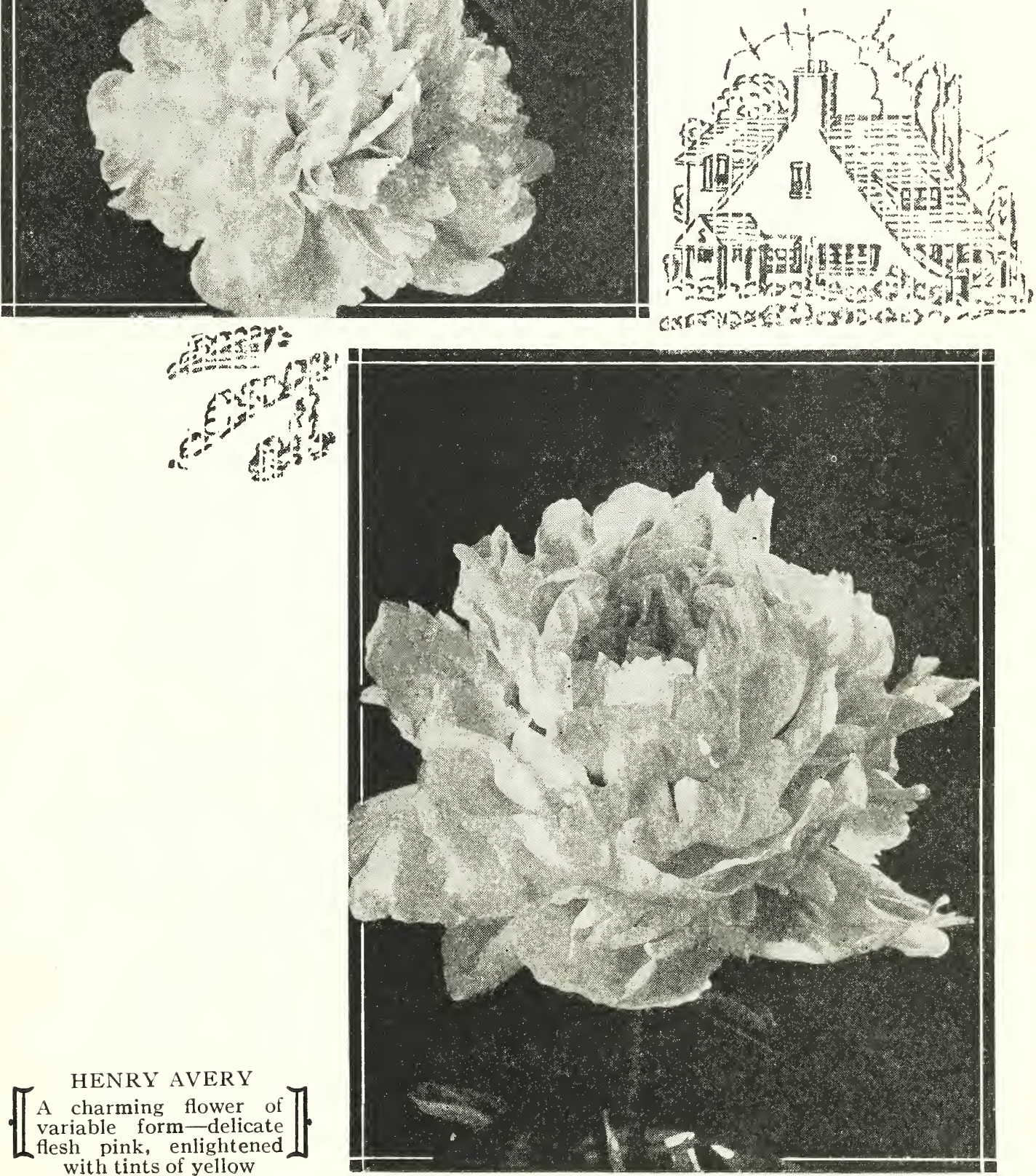


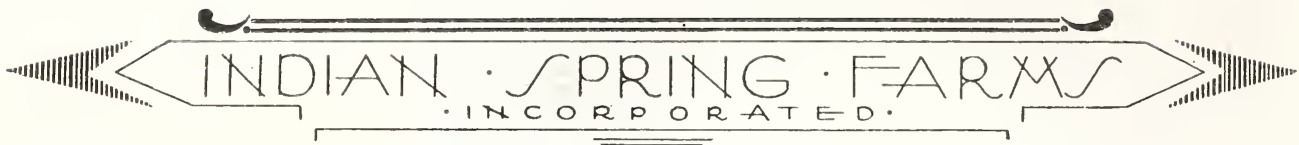

AUGUSTE DESSERT (Dessert 1920) 8.7. A comparatively new French variety that Dessert considered worthy of bearing his own name, but which is just becoming known in this country. From his own description it is a "cup-shaped flower of fine form, with rounded petals, very brilliant, velvety crimson-carmine, with silky reflex and often streaked white, very large silvery border; visible stamens intermixed with the petals in many flowers. A superb variety, awarded Certificate of Merit at the Paris Show, June 2, 1920." The color is absolutely a new shade between a light red and deep pink that is distinct and attractive. On well-established plants the flowers show a symmetry and refinement of petalage that, together with the unique coloring and the desirable habits of the plant, are certain to make this one of the most popular of all Peonies.

$\$ 7.50$

AUGUSTIN D'HOUR. Syn. Marechal MacMahon (Calot 1867) 7.8. The very large, medium-compact flowers of the bomb type are dark, brilliant, solferino-red, with a silvery reflex. The plant is of tall, strong, erect growth, with dark, rich green foliage, and blooms freely in late midseason. In spite of the fact that this is an old variety and sells at a popular price, we find it to be one of the most desirable red Peonies for landscape use.

$\$ 1.00$

AUNT ELLEN (Brand 1907) 7.2. An early red that follows immediately after the very early Richard Carvel. The flower is uniform, rich, purplishcrimson, of a loose, semi-rose type. A free and reliable bloomer that can be depended on.

$\$ 1.00$

AVALANCHE (Crousse 1886) 8.7. Large, compact, globular flower of pure snow-white, with a collar of creamy-white surrounding a center delicately tinted lilac-white in which a few of the wide petals are edged with a minute marking of carmine. A chaste and beautiful variety of perfect form, delightfully fragrant. The plant is medium tall, strong, and upright, and a free bloomer. Coming in late midseason, as the good, early, white varieties are going, this is one of the choicest whites either for landscaping or for cutblooms. We consider the varieties Albatre and Avalanche as identical.

$\$ 1.00$

AVIATEUR REYMOND (Dessert 1915) 8.0. A large, semi-double flower of beautiful, bright cherry-red, shaded garnet and brilliant amaranth. It is a showy variety that attracts attention when well done.

$\$ 2.00$

BALL O'COTTON (Franklin 1920) 8.8. A charming variety. The flowers are globular, perfect rose type, and spotless white. They open in midseason, are delightfully fragrant, and retain their ball form with the same perfect petal arrangement that we have in Le Cygne. The blooms are not as large as Le Cygne, but are more fragrant, and the growth of the plant is not as tall and imposing but the habit is good. When better known we believe Ball o'Cotton will be accredited a place among the finest Peonies. The stock of this fine Peony is still limited.

A few words must be said here in appreciation of the Franklin Seedlings, the originations of Mr. A. B. Franklin of Minneapolis, Minn. By the late symposium of the American Peony Society, nine different varieties, covering a wide range of form and color, are accredited ratings of 8.5 or better. Three, indeed, have reached the coveted 9.0 class. From our own experience we have found these new Franklin varieties all to be good, strong healthy plants without faults. Mabel L. Franklin, June Day, Ball o'Cotton, Mary P. King and Red Bird are all distinctly different flowers of fine quality that will prove worthy additions to any collection. 


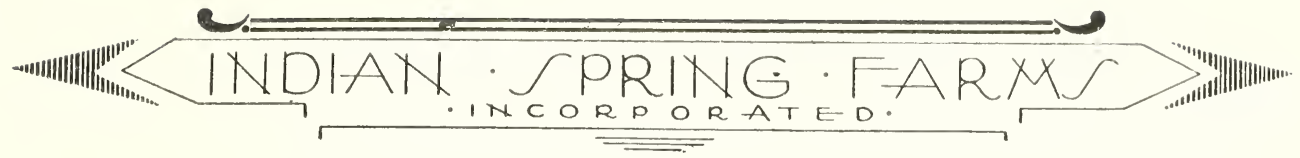

BARONESS SCHROEDER (Kelway 1889) 9.0. One of the finest Kelway Peonies. Its very large, full, globular flower opens a delicate flesh-white, changing to chaste creamy-white. The variety has a bewitching habit of coming, under certain conditions, a wonderful shade of soft baby-pink so deep that one is inclined to class it as a pink Peony. The petals have wonderful substance and fine form, and the delicate rose fragrance is most pleasing. The plant is of strong, upright growth, with a distinctive clean light green foliage. The well-formed buds, as well as the profuse blooms that open in late midseason, are carried with an aristocratic style that makes this one of the most beautiful and desirable plants for landscape plantings.

$\$ 1.50$

\section{See "Backbone" Collection, page 84.}

BEAUTY'S MASK (Hollis 1904) 7.9. A late variety having large, compact, crown-type flowers of clear blush-white, tinted lilac. The collar is lighter than the guards, with creamy-yellow petaloids intermingled, producing a distinctive color effect. Free-flowering and fragrant.

$\$ 1.50$

BELISAIRE (Lemoine 1901) 7.6. Another Lemoine variety that adds variety to the fine flowers to his credit. The large blooms, of globular, semi-rose type, are pale lilac, splashed and stippled with minute dots of deeper lilac, and slightly marked crimson on the guards and center petals. Medium tall, strong, upright growth. Midseason. In flower, the variety closely resembles Asa Gray, but is distinguishable by its red-tinted stems, while those of Asa Gray are green.

$\$ 1.50$

BENJAMIN FRANKLIN (Brand 1907) 8.1. One of Brand's older reds that is now demanding attention. The medium-sized flower, of semi-rose type, is brilliant crimson, with darker shadings at the base of the petals. Blooms that open slowly and hold their form and color much longer than most red varieties are produced singly on very tall, erect stems in early midseason. One of the very best red Peonies, either for landscaping or for commercial cut-flowers. We believe we have the largest stock of this variety outside the Brand Farms.

$\$ 1.00$
Mr. Brand has long insisted that Benjamin Franklin is a Peony not properly appreciated. It now seems that he has been right, for the late symposium boosts the rating from 7.6 to 8.1 . When an originator places eight red Peonies on the market in one year, leading off with such star varieties as Longfellow, Mary Brand and Charles McKellip, and then follows up in succeeding years with six more reds, including Lora Dexheimer, Richard Carvel, Winnifred Domme and Brand's Magnificent, it is little wonder that one good variety gets lost in the shuffle. It takes years for the Peony world to properly digest such a bounteous feast, and we predict that $\mathrm{Mr}$. Brand will see still further revision of the appreciation of his wonderful reds in future symposiums.

BERLIOZ (Crousse 1886) 7.0. A very large, compact, rose-type flower of globular form with imbricated petalage. The tall, strong-growing plant bears its enormous blooms of bright carmine-rose boldly above the foliage in a way that never fails to attract attention. As the blossoms age, the petals become distinctly silvered full half their length, producing a grayheaded effect so well done that it is really phenomenal. On close examination the petals are coarse, and the whole flowers lack the refinement of a really fine Peony.

$\$ 1.00$

BERTRADE (Lemoine 1909) 8.6. A large flower, globular, rose type, with broad, rounded petals of good substance, symmetrically placed. The color is ivory-white, with slight carmine markings on the backs of the guards. The plant, when well established, is of strong, vigorous growth, with stiff 


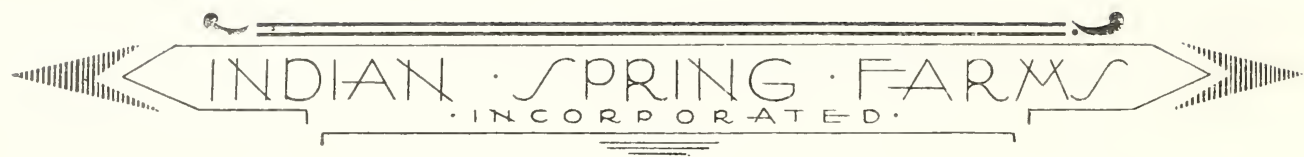

BERTRADE (continued)

stems that are characteristic of most of the Lemoine Peonies. A midseason variety that opens well. This French variety is proving its sterling worth as it becomes better known. Formerly rated at 8.1, it now stands at 8.6. Like many of the Lemoine varieties, it is slow to become established. The roots are clean and healthy.

$\$ 3.00$

BETTY BLOSSOM (Thurlow 1925). An interesting and beautiful new Peony that demonstrates the possibility of an ultimate attainment of that ambition of the hybridizers - a true yellow Peony. The flower is large, crown type, with lovely white guard petal faintly tinted yellow and sometimes flecked crimson on the back, and with a center of clear, almost translucent white, intermingled with a collar of narrow petals heavily edged with gold that gives a distinct yellow effect. The extreme center is composed of short, narrow staminodes of clear yellow. The total color effect is soft yellow that holds well. Awarded a Certificate of Merit by the American Peony Society in 1923.

$\$ 15.00$

BIEBRICH (Goos \& Koenemann 1912) 8.7. A large flower of flat rose type that blooms late. The color is soft flesh-pink, changing to white. A free bloomer on a plant of vigorous growth and strong stems.

$\$ 4.00$

\begin{abstract}
Biebrich is one of an interesting lot of Peonies from Goos and Koenemann that were first sent to his country for the test planting of the American Peony Society at Cornell. For some reason they have not yet become very widely disseminated. They are all highly thought of by those who are familiar with them and the varieties that have been submitted for rating have fared well. Gretchen, Lorch, Koenigswinter and Strassburg are all distinct Peonies that will prove their worth
\end{abstract}

BISHOP BURKE (Vories 1924). This interesting Peony is one of the remarkable "quartette" of seedlings introduced by Judge Vories that has held the attention of the peony world for the past several seasons. It is a distinct red that is different in every way. The flowers are medium to large and are all alike, of perfect rose form with broad, smooth petals symmetrically imbricated. The color is rosy crimson with an effective silvery sheen throughout. The plant is medium tall and erect and of faultless habit. A beautiful garden variety that is adaptable to any decorative planting.

$\$ 20.00$

BLANCHE KING (A. M. Brand 1922). Very large, full, globular rosetype flower, with large, imbricated and incurved petals that open very symmetrically. It is bright, glistening, deep pink in color, with a silvery reflex. The plant is medium tall, with sturdy, upright habit and good stout stems. Foliage a rich, dark green. Granted an Award of Merit by the American Peony Society on its first showing at London, Ont., in 1922.

$\$ 50.00$

BOULE DE NEIGE (Calot 1867) 8.0. Large, cup-shaped, semi-rose type bloom of good form and substance, milk-white, with guards and center prominently flecked crimson. The intermingled yellow stamens reflect a golden tint through the petals. Fine, strong, upright grower with long, stout stems and a heavy dark green foliage. Good for landscape use or cut-flowers, coming into bloom immediately following Festiva Maxima, which variety it strikingly resembles. Strong, sweet fragrance.

$\$ 1.00$ 


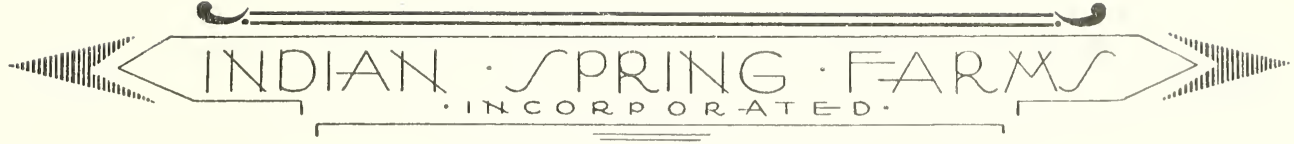

BRAND'S MAGNIFICENT (Brand 1918) 8.2. One of the newest of the Brand reds, and one of the best. A perfectly formed, semi-rose type flower of large size in which all the petals are broad and well rounded and more symmetrically placed in the true rose form than we find in most red Peonies. The color is a rich, dark, velvety red, with a decidedly bluish tone that is very distinctive. It is a profuse and reliable bloomer on a plant of medium height and faultless habits. A strikingly distinct and beautiful midseason red.

$\$ 3.00$

\begin{abstract}
Much has been said in condemnation of blue tones in red Peonies, and there is a tendency to rate as not good any red variety having a bluish cast. We agree that a Chinensis Peony with the clear, pure red color of Officinalis rubra is a worthy ideal, and a thing to be sought after, but, unfortunately as yet, "there ain't no sich animal," and we are loath to judge the best of the red Peonies we do have on a comparative basis with an ideal that does not exist. Such "blue" Peonies as Brand's Magnificent and Dr. H. Bransby are distinct varieties, and beautiful in their class. It seems quite as unreasonable to condemn an otherwise meritorious Peony. because one personally does not admire the blue-reds, as it would be to condemn a deep pink variety because one likes the light pinks best, or to condemn blotched gladiolus because one personally prefers the self colors. Brand's Magnificent was shown at the National Peony Show in Des Moines in fine form in the winning exhibits of at least four of the most important classes. There, in company with all the world's best red varieties, it attracted more attention and brought forth more favorable comment than any other red Peony. The public liked it, therefore we contend that even bluish-red Peonies may be good, and we say that Brand's Magnificent is a far better variety than its present rating of 8.2 would indicate.
\end{abstract}

CANDEUR (Dessert 1920) 8.4. Large, globular, cup-shaped flower of semirose type, with outside guard petals broad and rounded, surrounding a center of shorter petals. The color is delicate silvery pink, slightly tinged lilac-rose, changing to an iridescent white, with center petals flecked with carmine. Tall, vigorous plant with fine, clear green foliage.

$\$ 4.00$

CANDIDISSIMA (Calot 1856) 7.1. One of the older varieties that still has a place because of its earliness, coming about three days before Festiva Maxima. The blooms are large, rose type, opening llat with wide guard petals of creamy-white and a center of sulphur-yellow, the carpelodes in the center tipped green. As the flower develops, the center grows to a globular form of pure white, with the guards reflexed. Tall, vigorous plant that blooms regularly and profusely. The blossoms have a delicious true honey fragrance.

50 cts.

GARNEA ELEGANS (Carlot 1860) 7.8. A beautiful flower of medium size and perfect crown-type form. The guards and center are broad petals of a delicate, clear flesh-pink, while the collar of narrower petals is mixed with small petals of bright, clear yellow. A charming cut-flower variety that is delightfully fragrant. Midseason. This variety has a pink-and-yellow color combination similar to Jeanne d'Arc, but not so large, and is more perfectly formed.

$\$ 1.00$

\title{
GHARLES MCKELLIP (Brand 1907) 7.8.
}

A very large, loosely built flower of typical semi-rose form that is especially beautiful in bud and holds a half-open form that is distinctive. In color, it is rich, bright red of a peculiar American Beauty cast that is different from the other Brand reds. The petals are broad and crinkled, with a silky sheen, and are so symmetrically

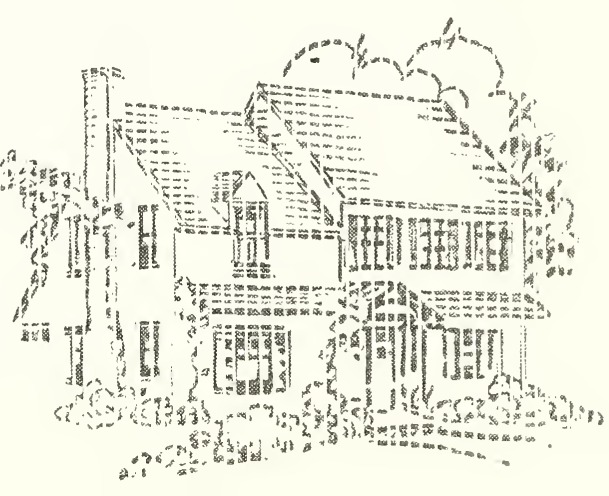




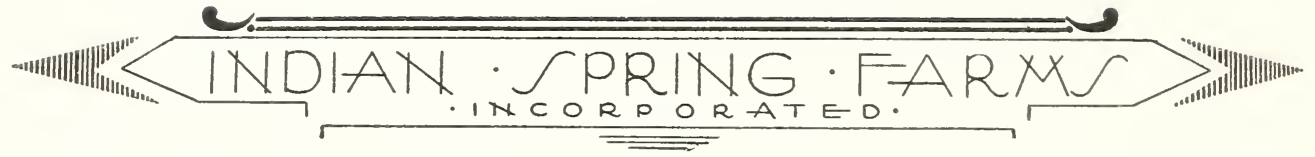

GHARLES McKELLIP (continued)

placed as to give the flower perfect form. In habit and foliage, the plant is good. Midseason. We have watched this variety carefully for several seasons, both in our own plantings and elsewhere, and are convinced that it is entitled to a higher rating than it now carries. At Duluth it is in greater favor than any of the other Brand reds. We recommend it for landscape and cut-flowers.

$\$ 2.00$

CHARLES VERDIER. Large, full, rose type flower of distinct dark ashesof-roses coloring, with wonderful fragrance. It is a medium tall, compact grower, and a free and reliable bloomer. Late. This seems to be sort of a mystery Peony. While it is one of the older varieties, its origin is unknown; it has never been listed for rating. The color may not please everyone, but we like it.

$\$ 2.00$

CHERRY HILL (Thurlow 1915) 8.6. A very early red Peony that is particularly fitted for landscape planting. The flowers are semi-double, deep garnet color, with a sheen that gives a bright, rich appearance. It is one of the earliest red Peonies to open, and the blooms last long in sun or wind, retaining their bright color until the last petals have fallen. The stems are long and very erect. This variety has been criticized on the ground that the flowers are small and not full enough, but on established plants the blossoms are of good size and come almost full double.

$\$ 4.50$

CHESTINE GOWDY (Brand 1913) 8.4. This is undoubtedly the best of the cone-shaped Peonies and the coloring is delicate and beautiful. The broad outer petals are a shade of silvery pink and surround a tier of closely set petals of creamy-yellow, while the center is a prominent ball of pink petals, similar in color to the outer petals, and prominently marked crimson. As a whole, the flower is full and evenly rounded to a symmetrical cone form. The habits of the plant are ideal, with stems that are long and slender, yet sufficiently strong to carry the single blooms gracefully above the foliage. A late midseason variety that is fine for cutting and is very fragrant.

It is unfortunate that the so-called cone-shaped Peonies do not retain their pleasing form throughout the life of the blooms. The flowers open flat and develop rapidly until they reach the stage of the cone formation, which is about the most perfect and pleasing of all the different bloom types. However, this form only holds for a day or so, and then a crown develops which is often more or less ragged, and the flower, as we say, finishes badly.

CLAIRE DUBOIS (Crousse 1886) 8.7. A late flowering variety and one of the very best. Its very large flowers are globular in form, with long, laciniated and incurved petals of uniform, clear violet-rose, tipped silverywhite. The blooms have the same beautiful silvery sheen that is noted on the earlier blooming variety, Monsieur Jules Elie. The plant is medium tall, erect, and strong growing. There is nothing among all the Peonies that is more strikingly beautiful than the immense, soft pink, ball-like blooms of Claire Dubois.

See "Backbone" Collection, page 84.

$\$ 1.00$

CLAUD GELLEE (Lemoine 1904) 7.8. This charming Peony will appeal to those who can appreciate beauty in a Peony even though it lacks size. The flowers are medium size, very flat rose type with perfectly formed petals, graduating in length toward the center and very symmetrically arranged. The color is creamy-white, with a tint of the brownish-yellow that we have in Alsace Lorraine. The plant is medium dwarf in growth, compact and upright and produces a profusion of blooms that are exceptionally uniform in size and shape. A vase of well grown blooms of Charles Gallee is very distinct and beautiful. If stocks of this variety were free from root disease, it would undoubtedly be rated much higher. 


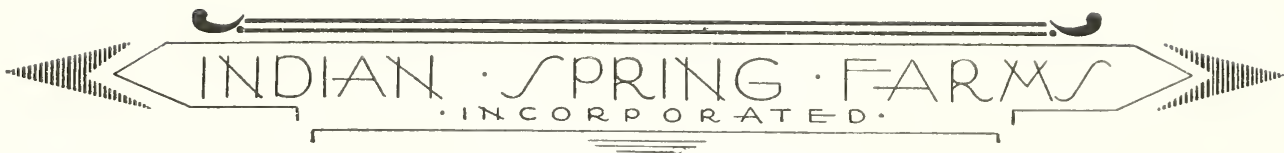

GLEMENGEAU (Dessert 1920) 8.5. A tall, strong-growing plant, bearing very large, imbricated flowers of full, compact petalage, carmine in color, slightly shaded amaranth, with silvery tints and a broad silvery border. A beautiful, very late variety of which the flowers always open well.

$\$ 6.00$

CORNELIA SHAYLOR (Shaylor 1917) 9.1. A large, full, well-formed flower that is "finished" both in shape and coloring. The guard petals and collar are delicate light pink, softening to white, and the center deeper shell-pink. In growth, the plant is strong and clean, and the tall stems carry the flowers like a graceful plume. A late variety that never fails to open well.

$\$ 15.00$

When new and expensive seedlings that have only been introduced for a short time receive high symposium ratings, we cannot but wonder how much the price has influenced the rating, and what the answer will be when the variety is judged on more mature plants and after longer observation. Cornelia Shaylor has now stood the crucial test of a second symposium rating, and we feel that her position is firmly established among the elite along with Georgiana Shaylor and Mary Woodbury Shaylor.

CORONATION (Kelway 1902) 8.5. A beautiful flower of high, flat, crown type. The large buds, delicately tinted pink, open into a compact bloom with broad, rounded guards of pale pink, flushed deeper pink on the back, and with a high, flat center in which the petals are arranged in tufted forms, delicate flesh-white, with golden lights at the base. Late midseason.

$\$ 3.00$

COURONNE D'OR (Calot 1873) 8.1. A pure white flower with bright yellow stamens arranged in a circle around the center in a way to reflect through the clear white petals and give the whole flower a true "crown of gold" halo. It is large, flat, semi-rose form, all white, with carmine tips on a few of the central petals. A splendid grower and a free bloomer in late midseason, coming just before Marie Lemoine.

$\$ 1.00$

CRYSTAL LAKE (Franklin). A large and attractive flower of semi-rose form, with its bright golden-yellow stamens prominently arranged around the center of the flower. In color, it is dark rose-lake that does not fade in the sun. Exceedingly strong and vigorous grower.

$\$ 2.00$

C. W. SCHOCK (Franklin). A full, double, rose-shaped flower of a very unusual shade of red that has no lustre. It is a good, medium-tall grower and a free and reliable bloomer. This is one of the newer Franklin seedlings that has not yet been submitted for rating.

$\$ 2.00$

DAVID HARUM (Brand 1920) 8.4. The latest addition to the long list of Brand reds. In color, it is a distinctive Tyrian-rose shade that is very pleasing. The flowers are very large and are most perfect bomb type, with a prominent collar of broad and rounded guard petals. In growth, the plant is tall and strong, with broad, clean, light green foliage. The stems are strong and carry the heavy blooms in perfect style. A profuse midseason bloomer. David Harum has all the desirable qualities of a landscape variety and is equally good for cut-flowers.

$\$ 5.00$

DE CANDOLLE (Crousse 1880) 7.2. A large, full, imbricated flower of rose form that is distinct in its color tone, a bright currant-red shaded with amaranth. A medium bloomer on a plant of good growth and foliage. Late midseason. 


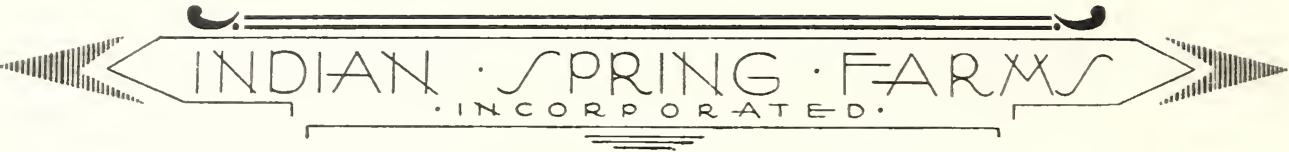

DEEMSTER (Kelway 1909). On paper, this is a very ordinary Peony, but as a garden plant it has so many good qualities that we continue to grow it. The flower is typical semi-double, with several rows of symmetrical, cupped petals surrounding a center of bright gold stamens. The color is dark brownish-red, or chocolate-maroon, that lasts long without burning or fading. The blooms are borne freely on an ideal plant of medium height. As a specimen landscape plant of rich, dark red, it has no superior. $\quad \$ \quad \$ 2.00$

DELACHEI (Delache 1856) 7.1. The large, full flowers are rose type. One of the best of the older red varieties that blooms very freely in late midseason. The color is showy violet-crimson, slightly tipped silver on the edge of the petals. The plant is medium strong and erect in growth. When the blooms are opened indoors away from the sun, the color is good and the flowers compare quite favorably with some of the supposedly better red varieties.

$75 \mathrm{cts}$.

DELICATISSIMA. Syn. Floral Treasure (Unknown) 7.6. A rose type flower of delicate salmon-pink. Its center petals are loose and spread just enough to show the carpels of light greenish-yellow, tipped white, giving a fresh and dainty color effect. The flowers are fragrant and, on strong plants, are very large and perfectly formed. A strong, tall grower, that makes a desirable landscape plant, and has exceptional keeping qualities for commercial cut-flowers. Midseason.

75 cts.

DESIRE (Brand 1922) 8.5. A very large flower of loose, semi-rose form. The petals are long and delicately colored mauve-pink. The plant is medium tall with clean light green foliage. Midseason to late.

$\$ 7.00$

The interesting history of Desire shows how even an originator can be fooled on the merits of his own flowers. As a seedling, the variety seemed to have much merit, and Mr. Brand showed it at the Minnesota State Horticultural Society Show in 1913 where it received an award. In transplanting the stock, it unfortunately was planted in a poor location, and for several years failed to show its true quality. In 1922 it was introduced at $\$ 5.00$, and the following year reduced to $\$ 1.00$. In other gardens, it quickly showed its wonderful quality, and before Mr. Brand realized it, his stock was nearly cleaned out. For the last three seasons, it has been in good demand at almost any price asked by those who have had it to offer, and even now stocks are limited at the price of $\$ 7.00$ per root.

DORCHESTER (Richardson 1870) 7.7. The very compact, rose type flower is a delicate shade of hydrangea-pink. It is one of the very latest Peonies to bloom, and, if it always opened well, it would be one of the outstanding varieties. Like many very late kinds, the buds sometimes water-log and fail to open perfectly. The plant is of medium height, upright, and shapely.

$\$ 1.00$

DUC DE WELLINGTON (Calot 1859) 7.8. Its large, bomb-shaped flowers have large, broad guards of pure white and a spherical center, that opens sulphur and changes to sulphur-white. It is a fine cut-flower variety that blooms in late midseason and is very fragrant. The vigorous, tall-growing plant has good form and habit and holds its flowers in pleasing style. Old Duc de Wellington is always a good variety, and sometimes its blooms, as we see them developed on the show table, compare most favorably with many of the supposedly better whites.

$\$ 1.00$

DUCHESSE DE NEMOURS (Calot 1856) 8.1. An early white of the crown type that opens in a globular, cupped form that is very distinct and beautiful. The color is clear white, with a collar of sulphur-white, and a greenish reflex at the center that is most refreshing. It is a vigorous 


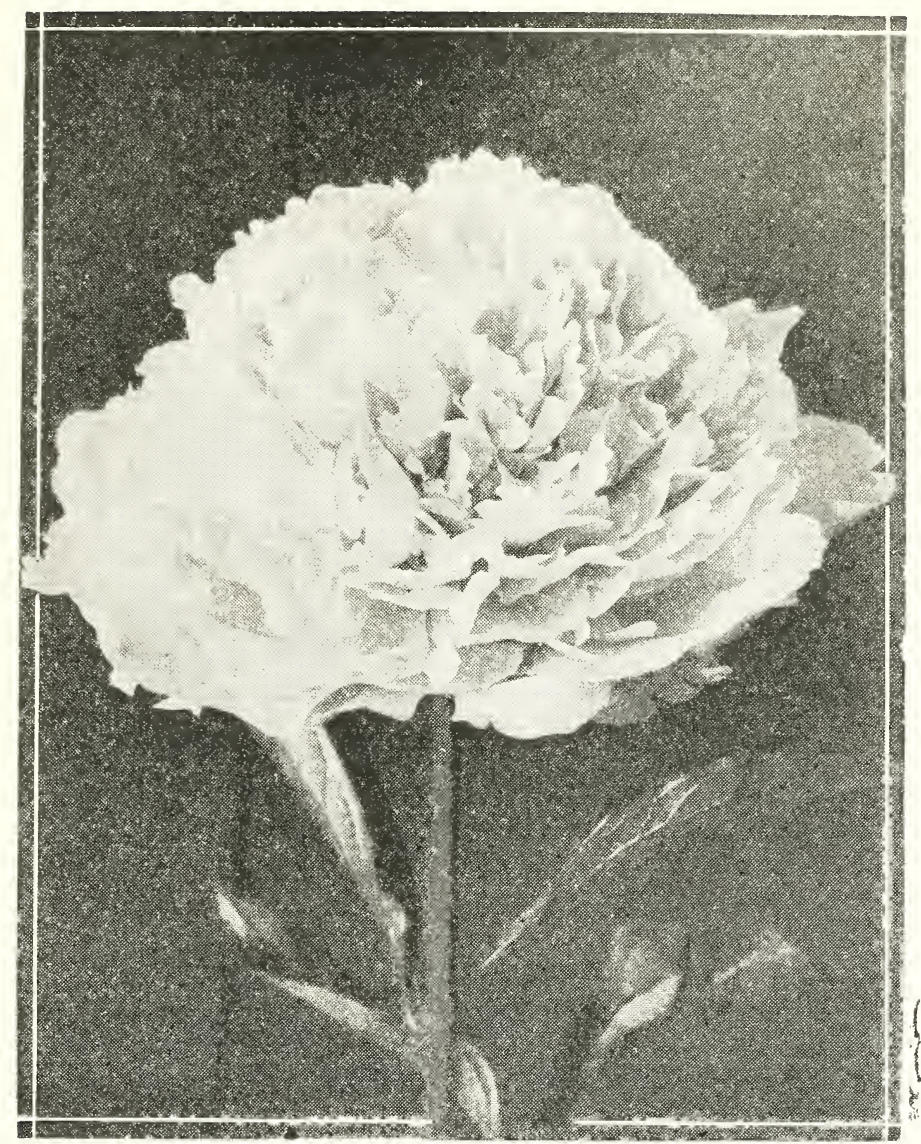
$\left.\left\{\begin{array}{l}\text { CORNELIA SHAYLOR } \\ \text { A refined flower of deli- } \\ \text { cate light pink color- } \\ \text { very beautiful }\end{array}\right]\right\}$

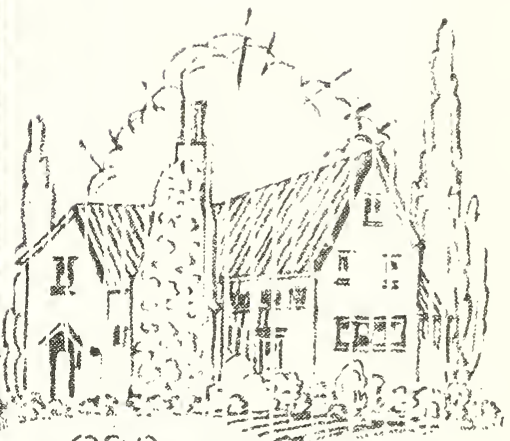

$$
\text { sond }
$$

$\mathbb{\|}$

$\left.\begin{array}{c}\text { E. C. SHAW } \\ \text { A beautiful light pink } \\ \text { Hower of dainty texture }\end{array}\right]$

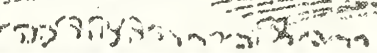

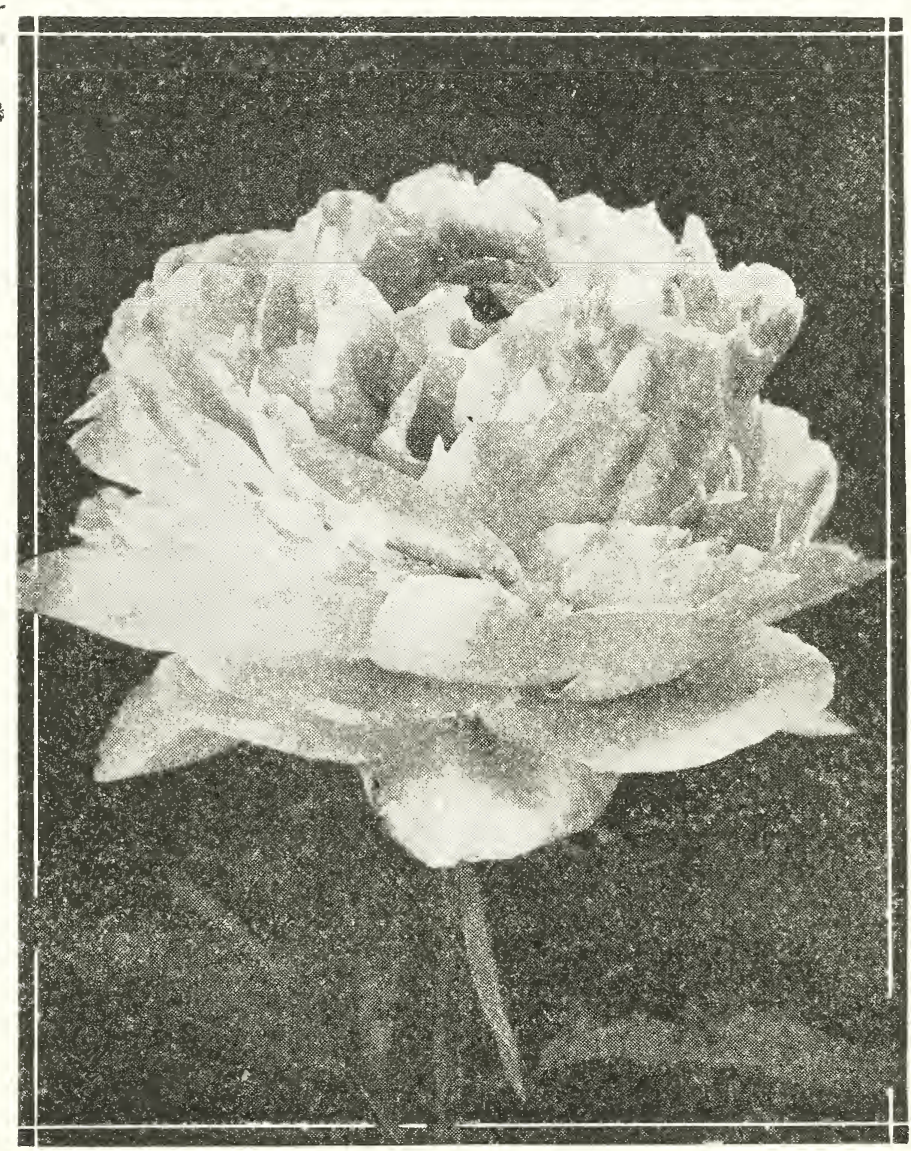




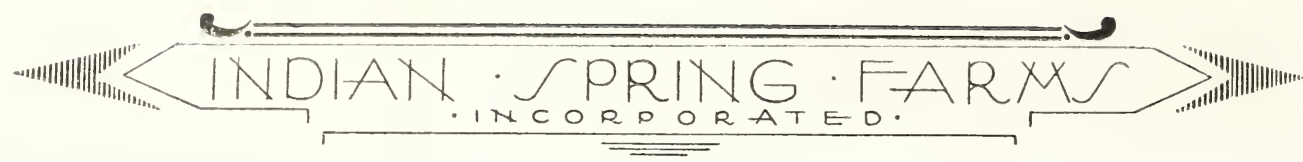

\section{DUCHESSE DE NEMOURS (continued)}

grower, of medium height, a free bloomer, and fragrant. A useful variety, either for the garden or for commercial cutting. This is another one of the older varieties that is distinct and outstanding, even when compared with all the newer and more expensive introductions.

75 cts.

It would be interesting to see as an entry at one of our National Peony Shows in the class of ten varieties, three blooms each, an exhibit all cut from wellgrown plants of these older sorts that can now be bought for $\$ 1.00$ a root. Such an entry, including Peonies like Duchesse de Nemours, Clara Dubois, Avalanche, Felix Crousse, Marie Jacquin, etc., would be hard to beat, even with a selection from the newer varieties. It would also go far in showing the uninitiated public that all the good Peonies are not expensive.

EDULIS SUPERBA (Lemoine 1824) 7.6. A very large, loose, crown-type flower, with guards and center of deep mauve-pink petals and a scant collar of narrow light lilac petals; the center is quite flat when fully open, with a silvery sheen. One of the most fragrant of all Peonies. The plant is vigorous in growth with slightly spreading habit. A very early variety that is usually in bloom for Decoration Day. Widely grown for commercial cut-flower plantings.

See the "Four Veterans" Collection offer, page 84.

EDWARD W. BECKER (Franklin 1920) 8.5. Another Franklin seedling that boasts of a creditable rating from the last symposium. It is a very attractive, semi-rose type flower of large size that opens flat, and in color is white, shaded light flesh. A free bloomer and fragrant.

$\$ 3.00$

EDWIN C. SHAW (Thurlow 1919) 9.1. A large, rose-type flower of dainty texture and refined coloring-a clear shell-pink. Its outer guard petals are broad and rounded, sometimes marked carmine, and the extreme center petals are short, giving the bloom a cupped shape. The plant has good habits and fairly stiff stems. One of the finest of the Thurlow seedlings. We one time asked Mr. W. H. Thurlow how they rated this Peony. His reply was that, in naming their seedlings, they had considered it fully the equal of the one that was eventually named President Wilson, and that they hesitated some time before finally deciding which should be named for the President and which for Mr. Shaw.

$\$ 20.00$

EDWIN FORREST (Hollis 1904) 7.5. This is another late midseason red that flowers when good reds are scarce. The blooms are only medium in size but are a beautiful shade of very dark crimson that does not fade. They are bomb type, with broad, shapely guards and a globular center rather scantily set with long, narrow petals. A strong, tall plant of rather spreading habit. A better variety for cut-flower use than for landscape planting.

$\$ 2.00$

E. J. SHAYLOR (Shaylor 1918) 8.7. The globular, compact bloom is deep rose-pink, shaded lighter at the tips of the petals. It is quite distinct because of the ring of petals, edged and tipped with gold, that surrounds the central petals. This same gold-edged petalage is found in Mr. Shaylor's white variety, Frances Shaylor. The plant is of medium height, strong and upright in habit, and blooms in late midseason.

$\$ 7.50$

ELEANOR ANN SMITH (Franklin). A very large, loosely built, semidouble flower with broad petals of dark violaceous pink that shade lighter at the tips; bright golden stamens showing conspicuously throughout. Fragrant. Midseason. A tall and vigorous plant that makes a striking color spot in the planting. 


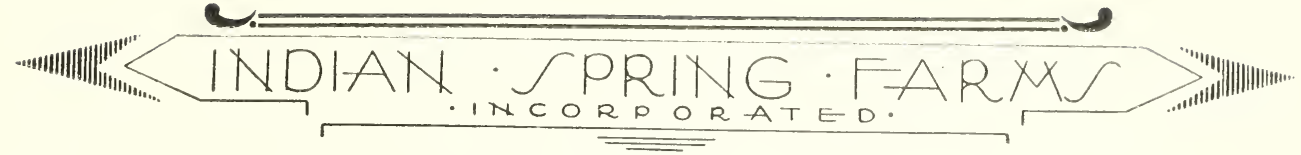

ELIE CHEVALIER (Dessert 1908) 7.3. A large flower of globular bomb form that grows a crown as it ages. The broad guard petals are Tyrianrose, splashed with green; center petals, broad and imbricated, are the same color as the guards and occasionally flecked with scarlet, with a pronounced silvery reflex. A free bloomer on a tall, spreading plant with long stems. The flowers are large and showy but lack the refinement and texture necessary to a real fine Peony. Fragrant. Late midseason. \$1.00

ELISA (Dessert 1922). This French variety, still rare in this country, appears to be worthy of a place among the truly fine Peonies. The flowers are large, rather loose, rose type with long, graduated petals that form a cupped center. The color is bright carmine-pink of soft shade, tinted salmon at the base of the petals, with a silvery reflex. The blooms show a symmetry of form and quality of petalage that is fine, and the coloring is very beautiful.

$\$ 10.00$

ELIZABETH BARRETT BROWNING (Brand 1907) 9.2. A very large, late-blooming, white Peony of semi-rose form. In the bud, the blooms appear glistening white, with the outer guard petals heavily striped crimson. These buds, themselves of very large size, slowly loose and expand until they become mammoth candy-striped balls rather than blooms. After holding this shape for two or three days, the flowers expand. First, the guards roll back, exposing a mass of artistically crinkled petals. These gradually unfurl into a bloom of immense size, white at the outside and deepening toward the center, with tints of blush and canary. When well grown in a rich, well-drained soil, truly wonderful flowers result. The plant is very tall and has a spreading habit that is objectionable for landscape use unless the stems are supported to hold up the weight of the flowers.

$\$ 3.50$

ELLA CHRISTIANSEN (A. M. Brand 1925). A large, loose flower of rose form that comes on a tall, vigorous plant with long, medium-strong stems. Its long, narrow petals graduate shorter toward the middle, forming a cupped center. The color is a soft, medium shade of pink that holds well throughout the life of the flower. A very free bloomer in midseason, with a pleasing fragrance.

$\$ 50.00$

ELLA WHEELER WILCOX (Brand 1907) 7.6. A markedly bomb-shaped flower with interesting variation in details. It is deep shell-pink, shading lighter toward the guards; and a row of irregular petals, edged crimson, surrounds an elevated cup-shaped center. A good, late cut-flower variety that is fragrant.

$\$ 1.00$

ELWOOD PLEAS (Pleas 1900) 8.7. This is a rose-type flower that comes in late midseason along with Couronne d'Or. It is of largest size, flat and full double, and is a shade of light shell-pink, with a lavender tone, that is very delicate and yet does not fade out in the sun. Its flowers last a long time and are fragrant. The plant is medium in height and has stiff upright stems that support the large blooms well. Its foliage is a rich, healthy green color and is set close to the ground, making a plant of pleasing landscape appearance. Mrs. Pleas considered Elwood Pleas her most valuable seedling. In favorable seasons it is truly a wonderful flower, and we have had it when we thought it the finest thing in the garden.

$\$ 3.00$

EMPEREUR NICHOLAS (Crousse 1897) 7.1. Large, ball-shaped flowers of semi-rose type. Color, brilliant amaranth, with a purple reflex. A very effective flower for landscape planting because of its brilliant coloring and desirable habits of growth. Midseason. 


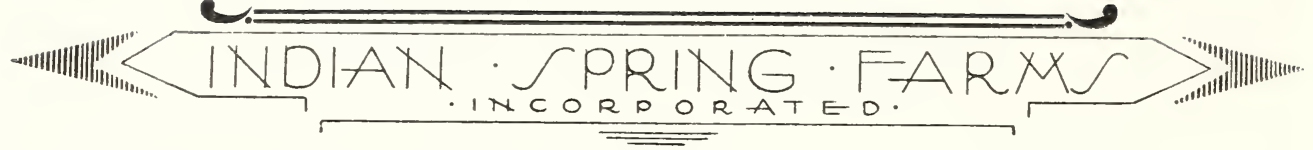

ENCHANTERESSE (Lemoine 1903) 8.9. A very large, globular, rose type flower of great beauty. In color, it is pure creamy-white, with guards splashed crimson, and the center of the flower sometimes faintly flecked crimson. The plant is very tall, strong growing and very late, and the immense blooms, held erect on tall, stiff stems, are slow in opening. The large buds loosen into big white balls, then develop to a half-open state that is beautiful. In time, the compact petals unfold into mammoth blooms of most perfect form and delightful fragrance. The variety is so very late that in hot weather the flowers do not always develop perfectly. It is, however, one of the finest white Peonies and a wonderful show flower. At the National Peony Show at Des Moines, six magnificent blooms of Enchanteresse were awarded the prize for the best six flowers in the show, a prize that only a real Peony can win.

$\$ 4.00$

ESTAFETTE (Dessert 1910) 7.9. A very early variety that is free flowering and showy. The flowers are large, globular, semi-rose form, and, in color, are purplish-carmine with a distinct silvery border. A medium tall plant of good habit. As a cut-flower, it lacks quality, but as a specimen plant it is most attractive.

$\$ 2.00$

ETTA (Terry) 8.0. A very large, flat, rose-type flower that blooms late, along with Grandiflora. It is a uniform shade of delicate hydrangea-pink. Very fragrant. One of Terry's best varieties that is proving its merit. It is rather a slow multiplier and the available stock is scarce. If this variety had stem enough to support the large, flat flowers in full bloom, it would be rated higher than it now is. For cut-flowers, it is very beautiful.

$\$ 1.50$

EUCHARIS (Lemoine 1909) 7.6. We had grown this variety four years and had just about made up our minds to discard it when we went into the garden one morning late in the blooming season, and discovered the plants loaded with about the most charming flowers we ever had seen on a Peony. They were high, globular, rose type, similar to a Baroness Schroeder bloom. The petals were rich creamy-white, of unusual substance, and so perfectly formed that they seemed moulded of wax. The fragrance was most delightful. As the plant has good form and habit and supports the blooms well, we marked the variety in our notes as being very good, and we have had no reason since to change our minds.

$\$ 2.00$

The longer we grow Peonies the higher regard we have for the introductions of M. Lemoine. In the varieties Le Cygne, Solange, La France, Mme. Emile Lemoine, La Fee, Alsace-Lorraine, La Lorraine, Bayadere, Enchanteresse, Lamartine and Sarah Bernhardt, we have a uniform standard of excellence not yet attained by any other hybridizer. The flowers have color, texture, symmetry of petalage, and refinement, and the plants have vigor and habits that are ideal. When we note such quality, we wonder if we are not overlooking like qualities in the other Lemoine kinds, some of which are badly infested with disease. Mr. Farr once made the statement that one who grew Lemoine Peonies must have much patience. If he was right, and patience is needed to wait for such varieties as Bertrade, Eucharis, and the others to become established, let us all have patience, for the results are worth the waiting.

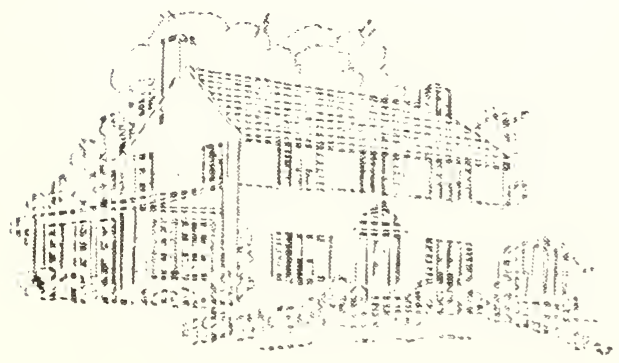

EUGENE BIGOT (Dessert 1894) 8.3. A typical, compact, semi-rose type flower of medium size that blooms in late midseason. In color, it is a brilliant, deep, Tyrianrose, with petals slightly tipped silver, and the scattered stamens are usually visible in the center. The plant is medium strong and upright in growth.

$\$ 1.00$ 


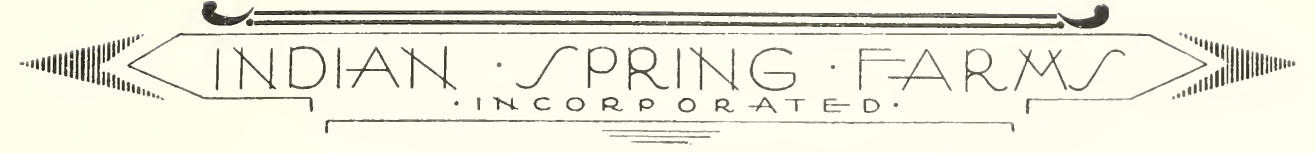

EUGENE REIGNOUX (Dessert 1905) 7.3. Where lots of color is wanted this is an effective landscape plant. The blooms are very large, globular, semi-double, with broad petals of deep carmine pink shaded silvery at the edges. The plant is vigorous and upright and literally covers itself with its large flowers in midseason. While the color does not meet the approval of all exacting critics, the variety has many friends.

$\$ 1.00$

EUGENE VERDIER (Calot 1864) 8.3. This is a very beautiful, cup-shaped flower of crown type, flesh-pink, with collar shaded yellow and salmon, and outer guard petals lilac-white. It is a late midseason variety, rather dwarf, of very upright habit, a free, reliable bloomer, and fragrant. The stems are straight and extra strong. This Peony is greatly confused, due to the fact that certain growers have failed to comply with the findings of the Nomenclature Committee of the American Peony Society, and are still selling the tall, strong-growing variety, recognized by the Peony Society as L'Indispensable, as the true Eugene Verdier at the higher price. The varieties are distinctly different. Eugene Verdier is rather dwarf and very erect in habit, with coarse, heavy foliage, and its buds open well. L'Indispensable is tall and spreading in habit, with dark green foliage and very distinct, flat, door-knob like buds that split underneath near the stem, water-log, and seldom open perfectly, except in the cooler climates.

$\$ 2.00$

EUGENIE VERDIER (Calot 1864) 8.6. This flower is very large, flat semirose type, a light hydrangea-pink, lighter at the outer petals, with center deeper, lightly flecked crimson. The blooms hold on a long time and finish paper-white at the circumference. Its delicately colored petals of fine, lacy texture make this a most beautiful variety for cut blooms. The stems are long and drooping. Fragrant. As a show flower there are few Peonies, if any, more attractive than a well-done bloom of Eugenie Verdier, with its very large size and soft pink coloring.

$\$ 1.00$

EUNICE SHAYLOR (Shaylor 1919) 8.9. A medium-sized, loose, semidouble flower that is very beautiful when grown on well-established plants. The outer petals are light flesh-pink, and the center, made up of broad, notched petals occasionally marked crimson and arranged in tufted form, is flesh-white, with a distinct salmon or golden reflex from the yellow stamens that are arranged in a circle around the center tuft and in the middle. The plant is medium tall and upright and holds its blooms in an erect position. Midseason.

$\$ 6.00$

EXQUISITE (Kelway 1912) 8.5. Very large flowers of loose, semi-double form in which the stamens are prominently displayed, adding a golden hue to the bright cherry-rose coloring of the long petals, tipped silvery white. The plant is strong and healthy, with a pleasing foliage, and the stems are strong, carrying the large, airy blooms in a graceful manner. Flowers in midseason. This is one of the finest landscape varieties, and is equally good for cut-flowers.

$\$ 3.00$

FANNY CROSBY (Brand 1907) 7.7. An early variety of crown type that comes as near being a true yellow as any Peony yet produced. The prominent guard petals are a lovely shade of sof $t$ pink, surmounted by a dome of true lemon-yellow incurved petals that are more or less heavily tipped white. As the flower finishes, it develops a crown and changes to white. It holds its yellow color longer than does either Laura Dessert or Primevere. The plant has good, strong, upright habits, and is a free bloomer. Its seeds are being widely planted in the hunt for a yellow Peony. 


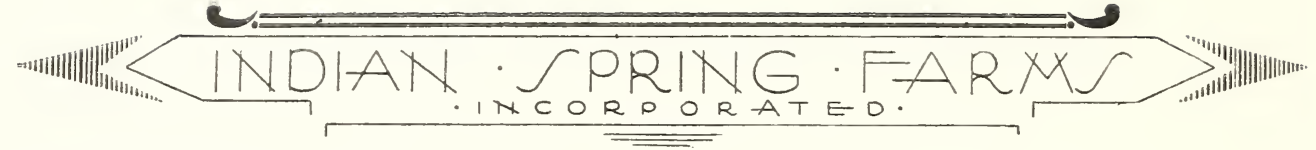

FANNIE LEE (Vories 1924). This well-shaped plant bears its medium-sized flowers freely on good, strong stems. The color is a distinct shade of American Beauty red, rich and velvety, that is very attractive and distinct. Midseason.

$\$ 6.00$

FARIBAULT (Brand 1918) 7.8. A deep pink flower with a silvery sheen, so distinct as to make it strikingly attractive. The blooms are large, rose type, and come late, along with Marie Lemoine. In color, it is a peculiar rose shade, changing to silver-white at the tips of the petals. The habits of the plant are good, and it is a free bloomer, making a showy plant in the garden.

$\$ 1.50$

FELIX CROUSSE (Crousse 1881) 8.4. One of the "Four Veterans" that has stood the test of years and is still one of the foremost Peonies, both for garden plantings and for commercial use. It is a large, typical bombtype flower of clear, brilliant red, coming in late midseason. The guard petals are prominent, surrounding a large, globular center of even coloring. It is a strong, vigorous plant of spreading habit, with stems that can hardly support the heavy flowers. By far the most popular of all the red Peonies for commercial cut blooms.

See the "Four Veterans" Collection offer, page 84.

FESTIVA (Donkelaer 1838) 8.0. A rose type flower, pure white with crimson markings, coming about a week later than Festiva Maxima. In color, it is more of a creamy-white than Festiva Maxima, and to many it is a more pleasing shade. The fragrance is strong and pleasant. Plant is dwarf and of drooping habit. The variety has been much used for commercial cutflowers under the names Edulis Alba and Drop White.

$\$ 1.00$

FESTIVA MAXIMA (Miellez 1851) 9.3. The highest rated of all the older varieties, and one of the most widely grown. Its very large, full blooms are true rose form, with very broad petals of purest white, and center petals irregularly flecked with carmine. It is a very vigorous grower, with splendid stems and handsome dark green foliage, and is an early bloomer, having pleasing fragrance. On first opening, the flowers sometimes show a delicate rosy tint in the center that is very beautiful. Festiva Maxima should be one of the first Peonies planted in any garden.

75 cts.

See the "Four Veterans" Collection offer, page 84.

FLORAL TREASURE (Rosenfield 1900) 7.5. See Delicatissima.

FLORENCE MACBETH (Sass 1924) 9.2. A new seedling of much promise that was awarded a First Class Certificate by the American Peony Society on its first showing at the 1924 Exhibit at Des Moines. It is an immense rose type flower that opens flat, and is soft La France pink, shaded lighter. The petals are very broad, of much substance, and have a crinkled effect that is very distinct and beautiful. Plant of strong, vigorous growth, with strong stems. From the short time we have been able to observe this variety, we consider it a most worthy addition to the list of high-rated Peonies.

$\$ 20.00$

FLOW'RET OF EDEN (Neeley 1924) 8.9. A large flower of the high-built rose form that develops and finishes in true crown type. The coloring is the soft, elusive, pink-and-white effect that we find so appealing in Peonies. On opening, the outer petals and center are delicately tinted baby-pink, and the collar is a soft creamy-white. As the flower ages, all change to almost clear white. The plant is medium tall and vigorous, with stems that droop gracefully under the weight of the heavy flowers. Midseason. 


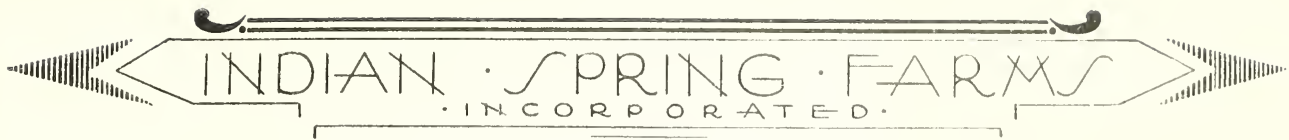

FONTENELLE (Rosenfield 1915). An early flowering red that is desirable for cut-flower planting on account of its season and its long, strong stems. The bloom is medium size, semi-rose type of good form. The color is clear, brilliant crimson.

$\$ 2.00$

FRAICHEUR (Lemoine 1914) 8.2. This medium-sized, semi-rose type flower has fine form and is creamy-white, with the guard petals delicately tinted flesh. Like many of the Lemoine varieties, the plants are slow to become established and do not show the real quality until well matured. Flowers in late midseason.

$\$ 3.00$

FRANGES SHAYLOR (Shaylor 1915) 8.6. A yellow and white flower of globular crown type that is quite distinct. The prominent guard petals of pure white are surmounted by a symmetrical dome of narrow, incurved petals of iridescent white in which are mingled at the collar partially transformed petals having a distinct edge of rich gold that light up the flower with a golden glow. This form of petalage is distinct and is also found in the variety, E. J. Shaylor. Dwarf; blooming freely in midseason.

$\$ 4.00$

FRANGES WILLARD (Brand 1907) 9.1. A very large, semi-rose type, pure white flower, that opens in a flat form, showing the golden stamens, and develops, as the petals grow, to a rounded form with a cupped center in which occasional petals are marked with carmine. On first opening, the flower is suffused with a delicate blush tint that changes in the sun to creamy-white. The plant itself is ideal, of strong, healthy growth, with sturdy stems and heavy, dark green foliage. It is a late midseason variety that is very fine, either for landscape planting or for cut-flowers. This is probably the most universally satisfactory of all the Brand Peonies. It does well in all localities, is a free bloomer, and is one of the finest white varieties.

$\$ 2.00$

FRANGOIS ROUSSEAU (Dessert 1909) 8.2. A really fine red Peony that is not yet known as well as it should be. In form, the flower is semi-rose type, and the stamens are symmetrically arranged in a ring, surrounding a tuft of central petals, and show in bright contrast against their brilliant red. On mature plants, the blooms become quite full, concealing the stamens. The color is lively, velvety red. It blooms early and the flowers hold their perfect form and brilliant color many days before falling. This variety, formerly rated at 7.5 , was boosted to 8.2 in the last symposium, and we confidently believe it will be rated still higher when its true merits are better known.

$\$ 5.00$

FRANKIE CURTIS (Vories 1924) 9.3. This new seedling was awarded a First Class Certificate of Merit by the American Peony Society at its first showing at the National Show at Des Moines, also the J. A. Taylor Prize for a new seedling of special merit. It might well be described as a white Monsieur Jules Elie. The flower is very large, bomb type, with a collar of large, prominent guard petals that is surmounted by a perfect chrysanthemum-like center. At first glance, the color appears pure white, but on close inspection it has light pink shadings on the center petals. A tall, strong-growing plant that holds the blooms upright. medium early.

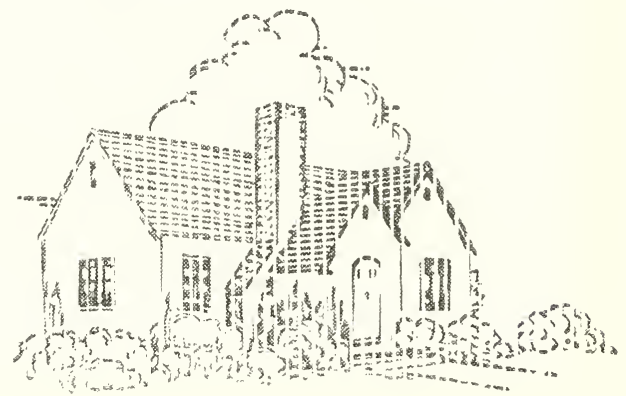




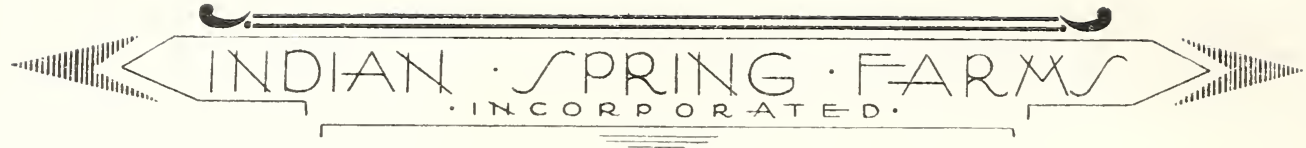

GALATHEE (Lemoine 1900) 8.1. A full, rose-type flower of very perfect form. The color is flesh-white, with a deeper pink center. One of the very latest varieties which develops slowly yet usually opens well. A tall, strong plant of good habit, as are most of Lemoine's productions.

$\$ 3.50$

GENE STRATTON PORTER (Rosefield 1925). This new Peony that flowered for the first time in our plantings last season showed all the quality requisite to a first class variety. The blooms are large and true rose form, with the guard petals broad and differentiated from the irregular petals of the collar that graduate to beautiful cupped center. The color is purest white throughout. The plant is strong and upright and flowers in late midseason.

$\$ 25.00$

GEORGIANA SHAYLOR (Shaylor 1908) 8.9. An exceptionally large, flat, semi-rose type flower of pale rose-pink; guards and center petals slightly splashed crimson. The petals are very broad and of fine texture and the color is so delicately shaded lighter as to make this one of the most refined light pink varieties. It is a medium-tall grower of sturdy habit, and the large blooms are carried well. Late midseason bloomer. It is one of the best of the Shaylor seedlings that has thoroughly proved its worth. $\$ \mathbf{\$ 3 . 0 0}$

GERMAINE BIGOT (Dessert 1902) 8.5. Large, full flower of the crown type that opens in a flat, compact form, developing a crown as the bloom grows. The general color effect is pale lilac-rose, tinted lighter salmonflesh in the center. The guards and center are splashed crimson. Growth strong, erect, and of medium height. A desirable variety for landscape use. Midseason.

$\$ 1.50$

GIGANTEA. Syn. Lamartine (Calot 1860) 8.2. Very large, rose type flowers, pale lilac-rose in color, shading darker toward the center. The blooms have an agreeable, spicy fragrance, distinct from that of any other variety. The plant is tall, but the stems are weak at the base, giving it an undesirable spreading habit. As cut-flowers, the blooms are very beautiful. The variety is in good demand and the stock is scarce. Lamartine (Calot) is undoubtedly the correct name, but as such it is confused with Lamartine (Lemoine), from which it is entirely different. To avoid error, it seems better to use the name Gigantea for the Calot variety.

$\$ 1.00$

GINETTE (Dessert 1915) 8.6. Large, imbricated, cup-shaped flower of semirose form, deep flesh in color, tinted salmon at the base of the petals, with the center petals frequently flecked with deep crimson. A fragrant variety and a free bloomer in midseason. The plant is dwarf in growth with strong upright stems. A good landscape variety where a low-growing plant is wanted.

$\$ 2.00$

GISMONDA (Crousse 1895) 8.2. A charming flower with a distinct pink and white coloring, and globular rose type form. The broad guards of rosy-white enclose a zone of narrower petals of like shade, and the center is a delicate pink of decidedly deeper shade, so distinctly divided as to give the appearance of a pink flower within a whiter one. Growth tall and strong, with stout, erect stems. A late variety and very fragrant. Very desirable.

$\$ 1.50$

GLOIRE DE CHARLES GOMBAULT (Gombault 1866) 7.9. A crown type flower of medium size that comes in midseason. The guards and crown are light rose; collar of narrower cream-white petals widening toward the center, center petals flecked carmine. A free bloomer on very long, strong stems. This is one of the best tri-colored Peonies. 


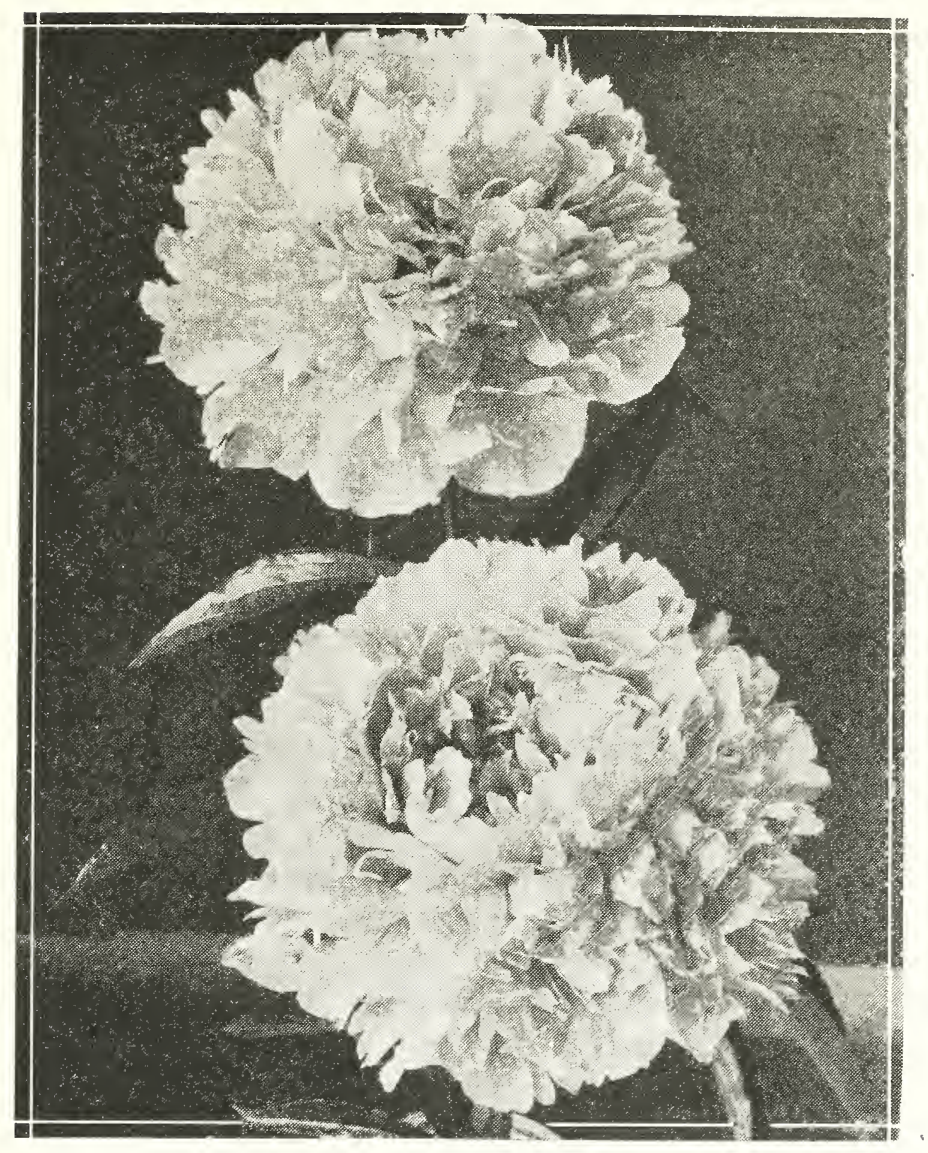

$\left\{\begin{array}{c}\text { LILLIAN GUMM } \\ \text { A delightful flower of soft } \\ \text { apple-blossom pink. One } \\ \text { of the finest }\end{array}\right]$

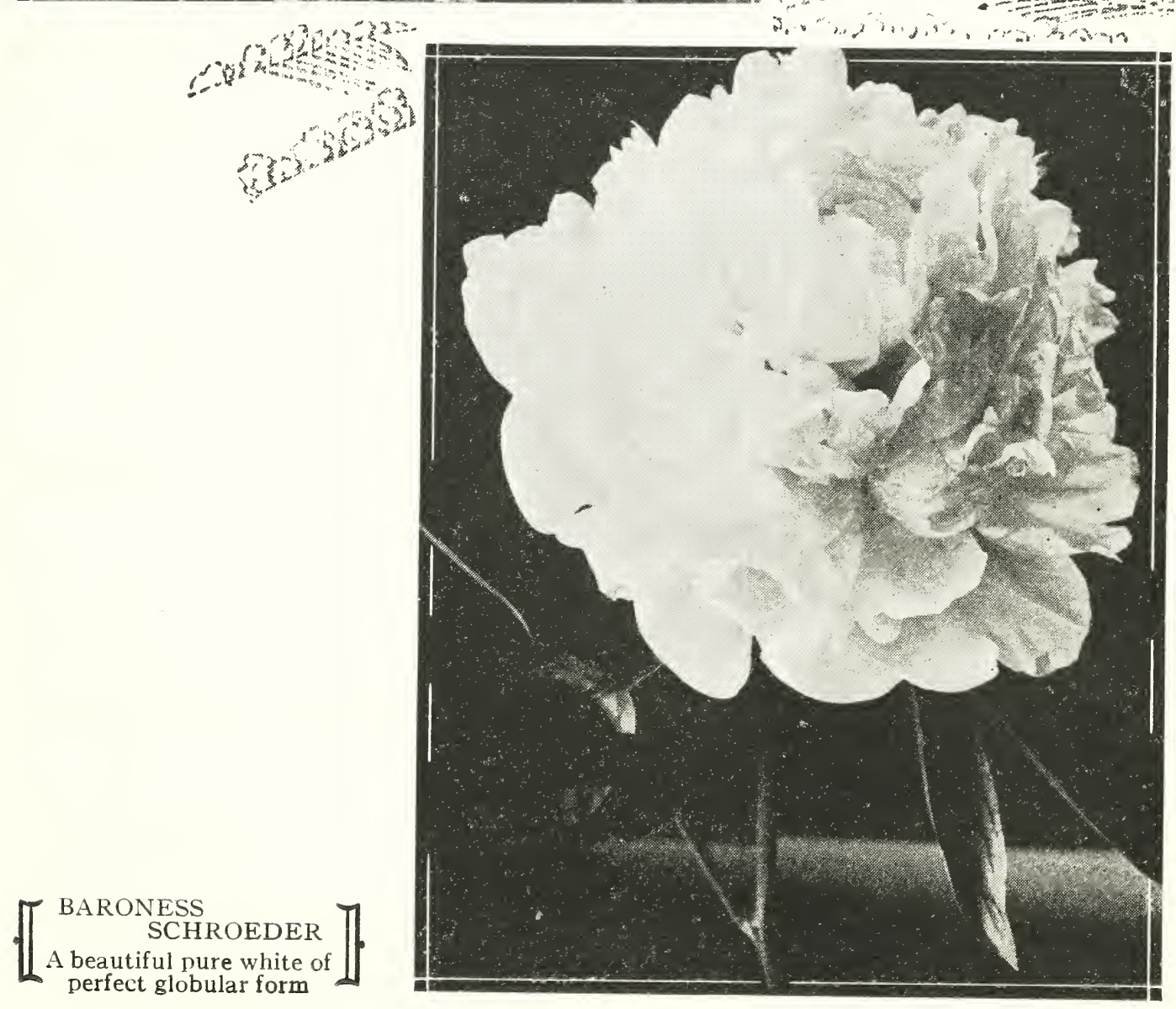




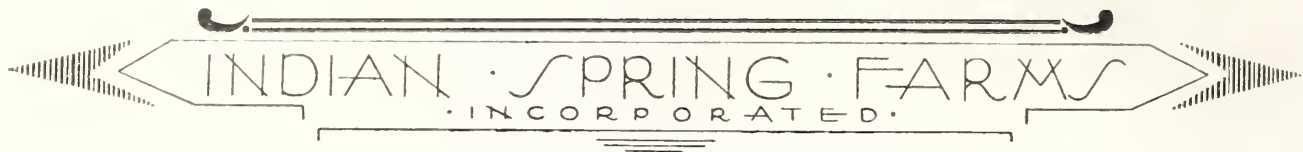

GLOIRE DE TOURAINE (Dessert 1906) 7.6. Large, very full, compact, semi-rose type flower in which the stamens are concealed. It is a very late variety, brilliant velvety red, with a purplish reflex. The buds are distinct, marked green. Plant is tall and upright, with strong, erect stems. Good landscape habits. There are two different flowers now being sold under this name. One, imported from Holland growers, is deep rosycarmine and comes into bloom two days earlier than the deeper crimson variety from France. We believe the darker red variety from France is the true one.

$\$ 1.50$

GOLDEN DAWN (Gumm 1923). A delightfully dainty blending of soft white and gold best describes the color of this attractive new seedling, that comes as a welcome addition to the class of so-called yellow Peonies. The flower is medium size, bomb type, and the broad, round guard petals are clear ivory-white, surrounding a symmetrically shaped dome of rather evenly formed petals, slightly incurved, that, when freshly opened, appears to give off a distinct golden glow like the rays of the morning sun. As the bloom ages, the color effect changes till we have the delicate blending as of new honey in its wax-like comb. When cut and opened indoors, the golden effect holds well, and we have, perhaps, the nearest approach to the much-sought-for yellow Peony. Delightfully fragrant. The plant has pleasing habits, erect, medium height, clean foliage and is a free bloomer. A very attractive variety.

$\$ 6.00$

GRACE LOOMIS (Saunders 1920) 9.2. Large, full, compact semi-rose type flower, clear white, with a reflected golden tint such as we note in a wellgrown flower of Marie Lemoine. The plant is medium tall and strong in growth, with stout stems. Blooming season late. A very fine variety suitable for any planting. This is undoubtedly the best of Professor Saunders' seedlings now introduced.

$\$ 15.00$

GRACE OTT (Gumm 1923). Very large, compact, semi-rose flower. In color, a brilliant, dark crimson, with occasional bright yellow stamens showing among the broad, well-rounded petals. It is a very tall, erect, strong grower and a free bloomer. Midseason. As a cut-flower, it lasts well, and on the plant it holds its form and color against sun and wind better than any red Peony we know. It has been our privilege for several seasons to watch this seedling, both in Mr. Gumm's plantings and our own, growing along with all the world's best red Peonies, and we are convinced that it is a distinct and worthy flower that will be rated high when known.

$\$ 10.00$

GRANDIFLORA (Richardson 1883) 8.8. The very large, flat, rose type flowers have a fine lacy petalage, refined in texture and, in color, soft shellpink, shading to rosy-white. In season, they are very late, and when one beholds the immense disc-like blooms of delicate beauty, even after a full season of beautiful flowers, it seems that Grandiflora makes a fitting climax to all that has gone before. The plant is of strong, healthy growth, with medium-strong stems.

$\$ 1.50$

GRANDIFLORA NIVEA PLENA (Lemoine 1824) 8.1. This is one of the very old Peonies that still has a place in every collection of any size. The flowers open in very large, compact, rose form and develop to crown type. The guards, milk-white, are broad and well differentiated, and the center is composed of large petals that are tinted salmon and sulphur-yellow on first opening, changing to pure white, and surrounded by a narrow collar 


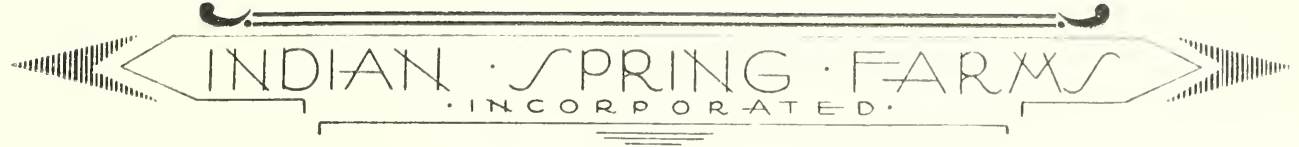

GRANDIFLORA NIVEA PLENA (continued)

of smaller petals of clear white. The center petals are flecked crimson. Very fragrant. The plant is strong and vigorous, with broad, deep green foliage. Very early. The stems are not sufficiently strong to make it an ideal landscape Peony, but it is desirable for cut-blooms because it comes so early.

$\$ 1.00$

Too often a Peony planting is planned with a view to having all high rated varieties, and certain kinds that would actually give the greatest pleasure are overlooked. Umbrellata Rosea, though rating only 7.4 , is always pleasing because it is the first of all the double Chinensis Peonies to bloom and comes when we have been waiting so impatiently for flowers. Grandiflora Nivea Plena blooms the next morning after Umbellata Rosea, and is the earliest large white. These two Peonies add at least two or three days to the length of the Peony season

GRETCHEN (Goos \& Koenemann 1911). A delicate and beautiful flower that opens in flat, rose form and then develops to crown type. The broad guards are notched at the ends and are well differentiated from the narrow collar of smaller petals which surrounds a full crown of broad petals that graduate to a deep, cupped center. The guards and center are soft flesh-pink, and the collar lighter. The plant is medium tall and upright. Late midseason. A fine flower and a very desirable variety.

$\$ 5.00$

GROVER GLEVELAND (Terry 1904) 8.2. This very large, compact flower of rose form is rich, dark crimson and blooms in late midseason. The plant is medium tall, and is a strong grower with rich green foliage and stout stems that support the heavy blooms well. If this variety were a free and reliable bloomer, we would accord it a place among the very finest reds. Either because it is naturally an erratic doer, or because the stock is partly sick - we have been unable to satisfy ourselves whichthe variety does not bloom well in many gardens. In our own plantings, it has bloomed freely, and we consider it our finest late red.

$\$ 1.50$

H. A. HAGEN (Richardson) 8.2. A large, compact, globular, rose type flower that comes late, as do so many of the Richardson varieties. It is a distinct shade of bright, clear pink, or deep violet-rose, that is uniform throughout - a beautif ul color that makes the variety a valuable addition to the limited list of good deep pinks. The plant is medium tall, with very erect, compact habit and good stout stems. Fragrant. A good landscape variety and an attractive show flower.

$\$ 3.00$

It is interesting to note how some of the older Peonies that were accorded low ratings in the earlier symposiums are now working their way to more prominent positions, for it is far harder for a Peony that has once been rated 7.7 to win its way up to a rating of 8.2 , as has $H$. A. Hagen, than it is for a supposedly good variety to slip down five points.

HANSINA BRAND (A. M. Brand 1925). Its large, very compact, rose type flowers open in a deep, flat form. The blooms are deep flesh-pink, shading darker at the base of the petals, with a salmon reflex-the most distinct in coloring of all the new seedlings. The plant is strong and upright, with very stiff stems that hold the flowers erect. Received an Award of Merit from the American Peony Society, London, Ont., 1922.

HARRIET BEEGHER STOWE (Hollis 1907). A very large flower of loose, flat, semi-double form with large irregular shaped petals of hydrangeapink that fade to milk-white. Plant tall, strong and vigorous. Early. This is the true variety and should be distinguished from the other variety in commerce under the same name, which is also a Hollis seedling that was introduced by Miss Anderson. 


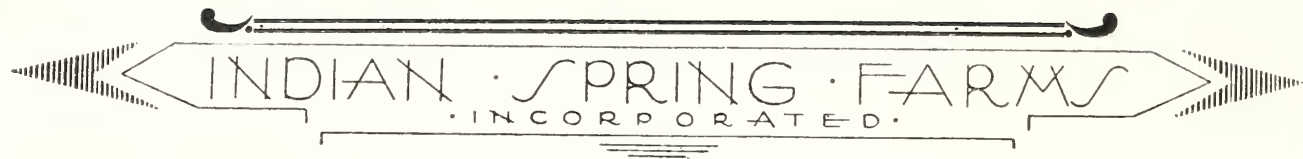

HARRIET FARNSLEY (Brand 1916) 7.9. Very late, rose type flower of light flesh-pink, similar in color and style to Mme. Emile Galle, but later and of better substance. Blooms large and borne one to a stem. One of the last varieties to bloom.

$\$ 1.00$

HAZEL KINNEY (A. M. Brand 1925). A large, deep, rose type flower with broad petals symmetrically arranged. The color is uniform hydrangea-pink, very delicate and clear. It has a plant of medium height, with clean, light green foliage. A profuse midseason bloomer and a beautiful flower of fine form.

$\$ 50.00$

HELEN WOLAVER (Brand 1918) 7.9. This is the most unique and, at the same time, one of the most fascinating flowers that grows. There is no other Peony anything near like it. The form is true rose type, and the guard petals are prominent, stiff, and of a seashell-pink, shaded with a deeper pink, or old-rose color. The flowers do not open fully, but the outer petals draw away, leaving a rosebud-shaped mass of petals in the center of the same deep rose color. The whole flower has such remarkable substance that it seems to be a creation made from wax rather than a living flower. It is highly rose-scented, and a very late bloomer. The plant is strong and thrifty and has good landscape habits. This variety is slow to establish and does not usually bloom typically until the fourth year. Unfortunately, it does not bloom well every year. We recommend it, not for a first Peony planting, but to the Peony lover who wants a novelty that is both interesting and beautiful.

$\$ 2.00$

HENRY AVERY (Brand 1907) 8.8. This is another Brand Peony that is growing in favor as it becomes better known. The flowers are large to very large, crown type, and, in general effect, light pink. The guard petals are prominent and the same shade of light flesh-pink as the center that is made up of large, rose type petals. Narrow petals of clear, bright yellow form the collar making a striking contrast, yet delicately beautiful. Very pronounced and pleasing fragrance. A plant of good, upright habit and fine stems. Midseason. A refined and beautiful variety.

$\$ 5.00$

HENRY M. VORIES (Vories 1924). A very large, flat, rose type flower, shaped somewhat like La France, with petals of wonderful substance, delicate light pink in color, darker in the center. The growth is tall and strong, with good stiff stems that support the flowers well. A distinct variety that blooms very late.

$\$ 15.00$

H. F. REDDICK (Brand 1913) 7.7. The brilliant, dark crimson flower is large, semi-rose type, and the bright yellow stamens are attractively intermingled with the red petals, tending to accentuate the brilliancy of the color effect. Plant is medium height, upright in growth, and a free bloomer. Midseason.

$\$ 1.00$

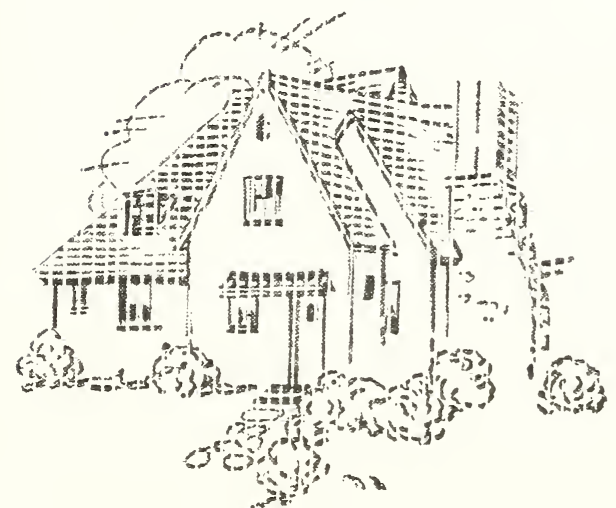

ISOLINE (Lemoine 1916) 8.3. A mediumsized flower of flat bomb type. The broad guard petals are clear white, and the center of narrower petals is sulphur-yellow on opening, changing to white. A distinct variety of symmetrical form and very fragrant. Plant growth medium tall and vigorous with stiff, straight stems. 
JAMES BOYD (Thurlow 1919) 8.9. A beautiful flower of very compact, globular, rose form, with long, narrow petals, flesh-pink, changing to nearly white, tinted at the base with a yellowish-salmon. The guard petals are notched at the tips, giving a fringed effect. One of the most delightfully fragrant Peonies. Late.

$\$ 7.50$

JAMES KELWAY (Kelway 1900) 8.7. Large, semi-rose type flower that comes in fine form in early midseason. The color on opening is a dainty flesh-pink, changing to flesh-white, and the stamens, almost entirely concealed in the large, rounded petals of translucent texture, reflect a golden glow that is very effective. A very tall, vigorous plant that produces flowers of immense size. The variety gives best results in a clay soil. It has been sold under the names Lady Derby, Kelway's Queen and Lady Carrington.

$\$ 1.50$

See "Backbone" Collection, Page 84.

JAMES R. MANN (Thurlow 1920) 8.7. The large flower is semi-rose type, having a few stamens in the center around the carpels, and the color is a deep, rosy-pink, with occasional crimson streaks in the center and on the back of the guard petals. Plant is strong and upright, with broad foliage. Blooms in midseason.

$\$ 15.00$

JEANNE D'ARC (Calot 1858) 7.9. Large, crown type flower, with guards and center soft pink, and a collar of intermingled petals of pink, salmon, and yellow color that makes a beautiful effect. The center petals are spotted carmine. Midseason. This variety is very similar to Golden Harvest, but the plant is a little taller and the flowers larger.

75 cts.

JEANNE GAUDICHAU (Millet 1902) 8.3. This large, compact flower of semi-rose form has petals beautifully laciniated, and the center ones bordered carmine. When the bloom opens, it is a delicate shade of pink, changing to white with a pinkish reflex. The fully developed flower is very dainty and beautiful, but the buds have a habit of opening with a water-logged appearance, as the color first shows, that is anything but promising. If the variety had a more pleasing bud development, it would surely bear a higher rating. The plant is medium tall, with strong upright stems. Blooms in late midseason.

$\$ 1.50$

JEANNOT (Dessert 1918) 9.2. One of the very finest of the recent varieties. The high-built, globular, rose type flower, with a cupped center is a delicate shade of flesh-pink with a tinting of lavender, lighted salmon-pink at the base of the petals. Plant is free and upright in growth, with slender but strong stems. Late. A fine landscape plant. This is another Feony that has been raised by the new symposium to the "nine" class. $\mathbf{\$ 1 0 . 0 0}$

JENNY LIND (Parsons 1860) 7.8. An old-timer that still has many faithful admirers. It is a strong, tall-growing plant, with upright stems that bear very large flowers of bomb shape. The color is light hydrangea-pink, with a silvery reflex, and narrow white petals are interspersed with the center petalage. Midseason. A free-blooming variety that has desirable landscape habits and makes a fine showing where an abundance of flowers is wanted.

$\$ 1.00$

JESSIE SHAYLOR (Shaylor 1916) 8.6. A large, midseason variety of flat, semi-rose form. The color is a delicate shade of deep cream, with a reflexed glow from the golden stamens that produces a distinct tea-rose coloring that is very beautiful. Plant grows medium tall, with good foliage and sufficiently strong stems to support the blooms well.

$\$ 5.00$ 


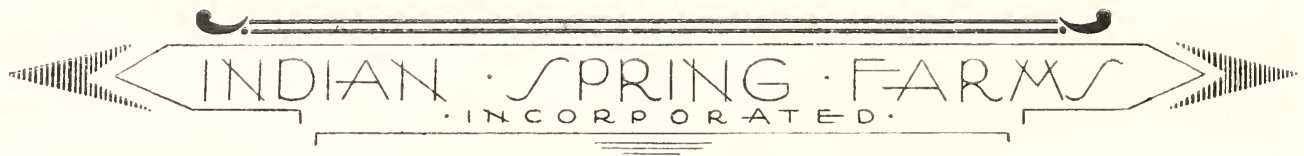

JOHN M. GOOD (Good \& Welsh 1921) 9.3. A late midseason variety that produces wonderful, large, full flowers of purest white. The blooms are true rose type with large, imbricated petals that build up into a symmetrical globular form that is almost perfect. It has ideal habits, tall and vigorous and very upright. The center stems grow taller than the outer ones, forming a beautiful dome-shaped plant as perfect in form as the blooms themselves. Stems are strong and support the large flowers perfectly. Foliage is distinctive light green color. Like many of the finer Peonies, the young plants are slow to establish themselves and do not bloom at their best until the third or fourth year. This wonderful Peony is one from a number of very fine seedlings raised by the late John M. Good and Ward Welsh. It was chosen as the finest of the lot by Mr. Good to bear his name, and it now remains as a most worthy tribute to the memory of one of the best Peony authorities this country has ever known.

$\$ 25.00$

JOHN RICHARDSON (Richardson) 8.2. A large, flat flower of compact rose type. The color is soft lilac-rose, shading lighter at the tips. Very fragrant. A strong plant of erect growth and compact habit. Late midseason.

$\$ 2.00$

JUBILEE (Pleas 1908) 8.9. A wonderful white Peony of largest size, often measuring 8 to 9 inches in diameter. It is flat, rose type, very full, with long, lacy petals of delicate texture that give the flower a refined appearance, yet last long, either as a cut-flower or on the plant. The buds are distinctly long and pointed and very large, and, on first opening, are white with a blush tinting that quickly changes to chaste snow-white. At first, the blooms are cup shaped but develop very broad and flat. The plant is tall and robust, with a peculiar and distinctive ruffled foliage. Unfortunately, the stems are long and willowy and incapable of supporting the mammoth blooms, so that the plant must be well supported to keep the flowers from trailing on the ground. We do not recommend Jubilee for landscape planting, but we consider it one of the finest of all Peonies for cut blooms or show flowers.

$\$ 2.00$

JUDGE BERRY (Brand 1901) 8.6. The very large flower is semi-rose form, and the petals are long and open back flat, forming a perfect disk-like bloom. Its season is early, being the first large pink variety to bloom. On opening, the color is soft light pink, changing to white and white, flushed pink, making a delicate pink and white effect. It is medium tall, and a free and reliable bloomer. The large size of the flowers and the early season of blooming make this one of the most desirable Peonies, worthy of a place in any planting.

$\$ 4.00$

JUNE DAY (Franklin 1920) 9.0. This new Franklin seedling has shown such remarkable quality in our own plantings and everywhere we have seen it growing that we unhesitatingly add it to our Approved Peony List. The large flower is rose type, a pleasing color, and deliciously fragrant. In color, it is light flesh with a lavender shading on the edges of the center petals. The plant is ideal in growth, strong, upright and has broad, leathery, dark green foliage. A free and reliable bloomer in midseason. We recommend June Day as being worthy of a place in the most exclusive collection.

$\$ 12.00$

KARL ROSENFIELD (Rosenfield 1908) 8.8. About the best all-round red Peony. The large, semi-rose type flower is rich velvety crimson and has a perfect ball-like form when fully open. Plant is tall, strong, and upright in growth, and bears a large, strikingly brilliant flower on every 


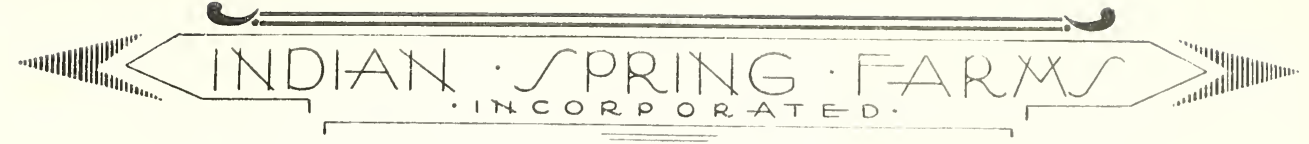

\section{KARL ROSENFIELD (continued)}

stem. The foliage is rich dark green and very heavy. Midseason. An ideal variety for landscape planting and equally good when cut. At a certain stage of development, a bloom of Karl Rosenfield is almost identical in form and color to a bloom of Mary Brand.

See "Backbone" Collection, page 84.

KATHARINE HAVEMEYER (Thurlow 1921) 9.0. A large, pleasingly formed bloom of the pyramidal crown form. The guards are a soft shade of lilac-pink, broad, rounded, and somewhat notched at the ends; the center petals, the same color, are broad and serrated, forming a high cupped center; collar of irregular narrow petals lighter in color. A flower of refined form and texture, and very fragrant. The plant is medium tall and vigorous, with good habits and strong graceful stems. Blooms in late midseason.

$\$ 20.00$

It is interesting to note that, by the last Rating List of the American Peony Society, twelve new seedlings, all the products of American growers. have been added to the exclusive list rating 9.0 or over. While it is probable that some of these, af ter further trial, will drop below the coveted 9.0 mark, none of them are likely to fall very far. There is still another dozen or more, yet too new to be rated, that have quality enough to assure them places near the top. This is conclusive evidence of the great interest now taken in Peony culture in America. It also means that many older varieties, now considered very fair Peonies, are due for discard as soon as stocks of these newer seedlings can be worked up to warrant reasonable prices.

KELWAY'S GLORIOUS (Kelway 1909) 9.8. A really glorious white flower that is rated next to Le Cygne as second best of all the white Peonies. The blooms are very large, full, double, rose type. They open white, with a suffusion of delicate flesh-pink and change to purest iridescent-white, and the guard petals are tinted pink and slightly streaked carmine on the back. The central petals are long and laciniated in well-developed blooms, forming a high, globular flower with a cupped center. Plant is medium tall, upright in growth, with strong stems that support gracefully the very large blooms. A good landscape plant that blooms in midseason. It is a free and reliable bloomer and usually flowers on young plants. This is, undoubtedly, the best of the many good varieties from Kelway. $\quad \$ \$ \mathbf{7 7 0}$

KELWAY'S QUEEN (Kelway 1909) 8.8. The true variety is one of the most beautiful Peonies. Its large, globular, rose type blooms, similar in form to Solange, have the center high-built and cupped. In color it is a uniform mauve-rose, with the broad center petals tipped carmine, and a tinting of carmine-pink deep down in the petals that livens up the bloom wonderfully. Fragrant. Midseason. The growth is medium tall, strong, and upright, with distinctive stems and broad, rounded foliage of a characteristic green color. Even well-established plants, make but few eyes and put up but few stems, and these branch close to the ground, sending off foliage stems that give the plant a large, bushy appearance. The plant is free flowering and each true stem produces a perfect bloom that always opens well. There is much confusion over this variety, Kelway having sent at least four different flowers to this country under the name of Kelway's Queen. This is, undoubtedly, the reason for the present low rating of the true variety.

$\$ 12.00$

KOENIGSWINTER (Goos \& Koenemann 1912). A very full and compact flower of semi-rose type that is high class both in its perfection of form and beautiful coloring. Soft lilac-pink with silvery shadings. The plant is strong and upright, and the flowers are borne on long, strong stems. Late midseason. 


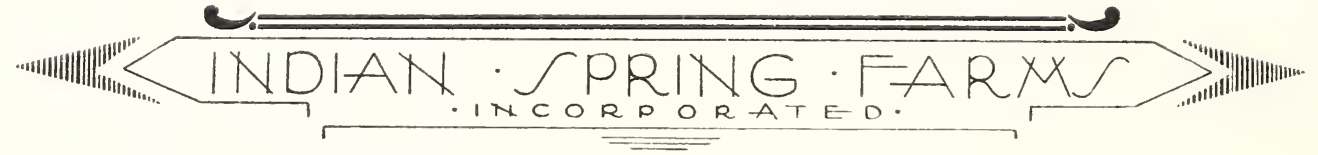

L'ECLATANTE (Calot 1860) 7.7. A free-flowering red of loose bomb type that makes a very satisfactory cut-flower in midseason. The broad guards are distinctly differentiated from the narrower petals that make up the center, and both are a uniform shade of bright Tyrian-rose. A strong plant of medium height.

$\$ 1.00$

L'INDISPENSABLE (Unknown) 7.2. Large, very compact, rose type blooms that open in late midseason. In color they are pale lilac-white, shading to light violet-rose in the center. The flowers are very large and globular and the petalage is so compact that the mammoth buds, which are of a distinct door-knob shape, do not always open well. In the cooler climate of the North and on the Pacific coast, the variety does well and is a very desirable flower. It is not recommended for planting where hot weather is liable to effect the blooming. L'Indispensable is being widely sold as Eugene Verdier at a higher price. L'Indispensable is a very tall, vigorous grower, while the true Eugene Verdier is more dwarf.... 75 cts.

LAFAYETTE (Dessert 1904) 7.8. An early and free flowering variety that is valuable for landscape use. The blooms are large and of flat rose form. The color is a medium shade of pink, or light violet rose, shading at the tips of the petals to silvery white. The plant is vigorous and upright, and bears its showy blooms on graceful stems.

$\$ 2.00$

LA FEE (Lemoine 1906) 9.2. A very large, compact, globular crown type flower that is delightfully colored, airy, and beautiful. It is rightfully named "The Fairy." The flower opens in a globular rose type form, with guards and center of soft mauve-rose, then develops to crown form showing a narrow collar of lighter petals. It is very fragrant. The plant is tall, vigorous, with long willowy stems that support the flowers with a plumelike air, and the foliage is distinctly ruffled. Blooms in early midseason. The true variety is justly rated 9.2, yet we find many good Peony authorities who are at a loss to know the true La Fee. Growers' plantings are mixed and much of the true stock is affected with nematodes. From good healthy roots the variety is a free and reliable, early-midseason bloomer, and is regarded by those who know it as one of the very finest Peonies.

$\$ 10.00$

LA FONTAINE (Lemoine 1906) 8.4. This is one of the Lemoine Peonies that is not properly appreciated. The flower is large bomb type, with broad, prominent guard petals surrounding a compact center, globular in contour with a flat top. The color is light violet-rose that is nearer a true lavender than any other Peony, and the center petals are tipped carmine. A flower of distinct, delicate color and very fragrant. The plant is typically Lemoine, tall, upright, compact in growth, with very strong stems. Foliage broad, heavy, and a distinct light green color. Blooms in late midseason. In both plant and flower La Fontaine is a distinct and worthy variety desirable for either landscape use or cutflower plantings.

$\$ 3.00$

LA FRANCE (Lemoine 1901) 9.0. Very large and compact rose type blooms of uniform rose-white, or apple-blossom-pink, with guard petals splashed crimson. A late midseason bloomer and fragrant. The plant is tall, strong, and upright, with long, stiff stems that hold the very large blooms in good form. One of the finest French varieties that blooms freely even on young plants. Desirable for landscape planting and wonderful as a show flower. 

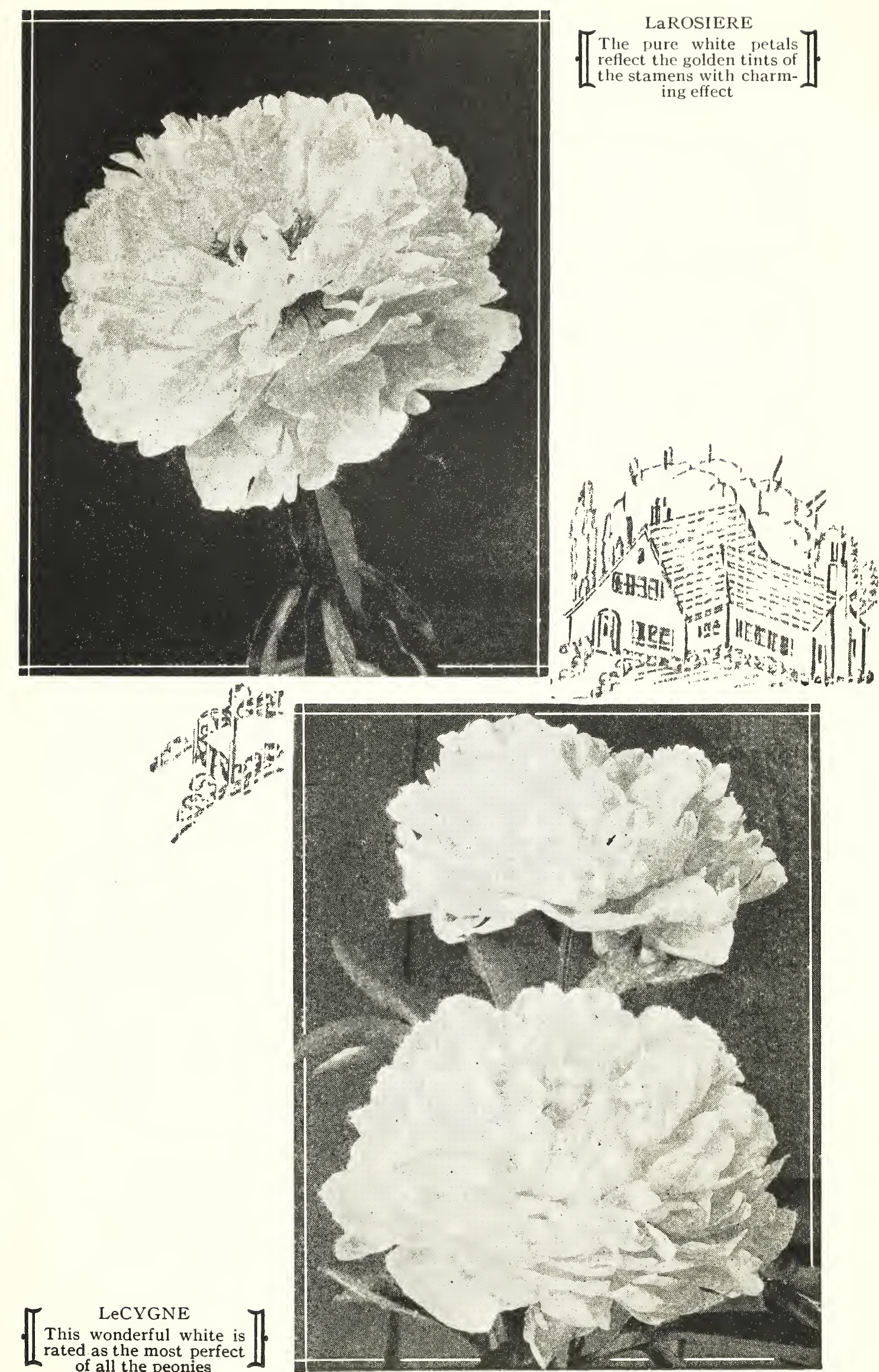


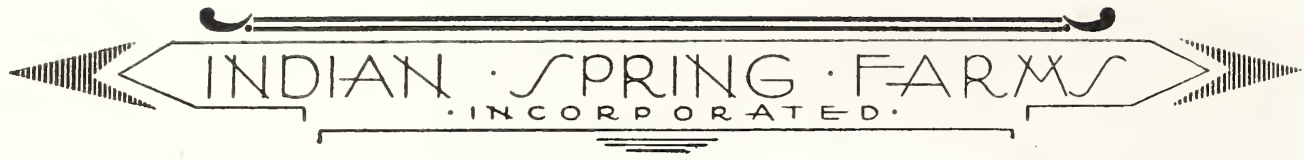

LA PERLE (Crousse 1885) 8.5. A truly fine Peony that is greatly undervalued. The flowers are very large, globular, compact rose type, with a color scheme that is quite distinct and very beautiful. The broad outer petals are delicate lilac-white and inclose a compact, globular center of wide petals that are deeper color-a soft violet-rose. The center band petals are flecked crimson. Very fragrant. The plant is extra strong with sturdy, upright stems. Late midseason. A fine cut-flower variety and a perfect landscape plant.

$\$ 1.00$

LA ROSIERE (Crousse 1888) 8.3. A beautiful midseason white of distinct form. The large, semi-double flowers have several rows of long, laciniated petals of purest white surrounding a disc-like center of bright golden-yellow stamens. They are borne in huge clusters of five or more on a stem, all open at one time. For the most striking effect the plant should not be disbudded. The plant has good habits with stems sufficiently strong to support the blooms. A wonderful landscape variety.

$\$ 1.00$

LA TENDRESSE (Crousse 1896) 8.1. An early white variety with large, flat, rose type flowers that have a compact, creamy-white petalage, changing to pure white. The guards are striped and the center petals more or less flecked crimson. The plant is tall, vigorous, and upright with good stout stems. Good blooms of this variety are very lacy and beautiful. Unfortunately, the buds sometimes water-log and do not open well, so that the variety cannot be classed as a sure and reliable bloomer.

$\$ 1.00$

LA TULIPE (Calot 1872) 7.5. This very large, semi-rose type flower expands from a tight bud into a very large, globular ball of blush-white, artistically streaked carmine; in certain seasons these usually distinctive stripes may be missing. At length these huge balls burst open into flat flowers of rather scant petalage showing stamens. Fragrant. The plant is tall and vigorous with long, strong stems. Midseason bloomer.

75 cts.

LADY ALEXANDRA DUFF (Kelway 1902) 9.1. The "Lost Peony" about which so much has been written. It is a very distinct and beautiful variety, with very large, flat, semi-rose form flowers that vary under different conditions from loose semi-double to quite full rose type. The guard petals are very broad and rounded, surrounding a center of irregularly arranged petals of varying size. On first opening the color is soft flesh-pink, changing to French-white suffused blush, making the flower neither true white nor pink. The terminal blooms come quite full and the lateral blooms, opening at almost the same time, come as saucershaped disks of pink and white that are very beautiful. The petalage is delicate in texture and the center petals are slightly marked carmine. The buds are large, pink, and distinctly striped carmine. It is a strong, upright, and vigorous grower, and flowers profusely in mid-season. One of the very best Peonies; desirable for both landscape use and garden planting.

LADY CARRINGTON (Kelway) 7.6. A very free-flowering variety that produces a wonderful landscape effect. The flowers are large, loose, flat, semi-rose type of variable form, borne on a plant of desirable habits. The color is pale silvery rose, shading to white at the ends of the petals. Fragrant. The plant is medium tall and flowers in midseason. We have found this variety mixed in commerce with James Kelway.

$\$ 1.50$ 


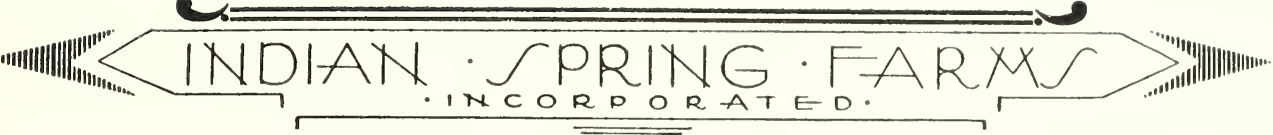

LADY IRIS (Pleas 1907) 7.9. A large, loose, semi-rose type flower in which the petals are long, broad, and silky. The color is a delicate salmon-pink, shading deeper toward the center. Established plants produce very large, full blooms that are fragrant and very beautiful. The growth is strong and healthy, and the stems are strong enough to support well the flowers that are produced in clusters. Midseason bloomer.

$\$ 2.00$

LADY KATE (Vories 1924). The large, rather flat, rose-formed flowers are perfect in shape, and the color is a uniform light mauve-pink that is distinct and beautiful. The plant is very tall, with strong stems and desirable landscape habits. One of the latest varieties to bloom. This new seedling won two prizes on its first showing at the National Peony Show in Philadelphia.

$\$ 25.00$

LAKE O'SILVER (Franklin). This large flower is semi-rose form, light pink, with golden stamens prominently intermingled with the petals. The central petals are darker, and all the petals are markedly silver tipped. A plant with good habits that blooms freely.

$\$ 3.00$

LAMARTINE (Lemoine 1906) 8.4. A flower that in its form and coloring is different from any other Peony we have. It has a perfect rose type bloom of high, globular form, with broad, imbricated petals that roll back like those of a rose, and the color is a deep carmine-rose, with each petal widely bordered silvery white. The plant is tall and vigorous with good stems. A late midseason bloomer and very fragrant. This is a good variety, very distinct, and worthy of a place in any coliection.

$\$ 5.00$

LAURA DESSERT (Dessert 1913) 8.8. This variety vies with Primevere for the honor of being the best yellow Peony yet introduced. The flower is globular rose type, with a collar of creamy-white guard petals surmounted by a symmetrical dome of lively canary-yellow petals. It is a perfectly formed bloom that, like all the other near-yellows, is delightfully fragrant. The plant is medium tall, with vigorous, upright habit and good, strong stems. As a landscape plant, it is better than Primevere which has a more spreading habit. Between the two flowers there is little to choose. An early midseason bloomer.

$\$ 7.00$

LAURA VORIES (Vories 1924). This new seedling has the same strong, vigorous habits that characterize all the Vories Peonies. The flowers are large, semi-rose form with their stamens intermingled in the collar petals. The color is delicate flesh-white, shading deeper pink at the center, with center-band petals irregularly edged crimson. The perfect form and dainty coloring make this a variety of much promise. It is somewhat similar in flower to Mignon.

$\$ 15.00$

LAVERNE GHRISTMAN (A. M. Brand 1925). A very large, loosely formed flower of rose type, similar in shape to a good Therese. The coloring is deep rose-pink, shaded lighter, and the petals are of refined texture, making a flower of delightful charm. Tall habit and vigorous in growth. $\$ \mathbf{\$ 5 0 . 0 0}$

LE GYGNE (Lemoine 1907) 9.9. This Peony, according to the votes of the members of the American Peony Society, comes the nearest to being a perfect plant and flower of all the hundreds of varieties. It is appropriately named "The Swan"-a wonderful flower of purest white, embodying 


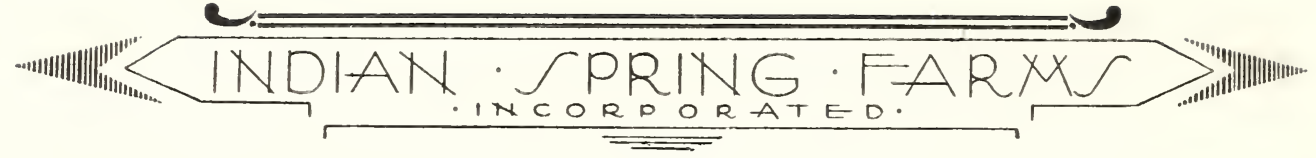

\section{LE GYGNE (continued)}

grace and beauty to the highest degree. In form, it is perfect rose type, large and globular, with broad, imbricated petals symmetrically arranged, that grow shorter toward the center. The color is creamy-white with a greenish luminosity at the heart, changing to pure white. Plant is of ideal growth, medium tall, with comparatively few stems, but each one equally strong and each supporting a perfect bloom most gracefully. The foliage is dark, rich green and heavy. It blooms in midseason and the flowers are fragrant. Desirable for either landscape planting or garden use, and well deserves the high rating accorded it.

$\$ 6.00$

LIBELLULE (Dessert 1922). An interesting new French variety that shows a variation of form ranging from loose Japanese type on young plants to full bomb type when fully established. The guard petals are flesh-white, and the center of narrower petals is soft flesh, occasionally marked with carmine and shaded straw-yellow and salmon at the base. Pleasantly fragrant. Stocks are yet very limited.

$\$ 7.50$

LIBERTY (Hollis 1905). A somewhat rare variety that produces a profusion of blooms of medium size, globular, rose type. Its color is uniform, dark magenta, shading to silver at the tips. Plant of medium growth. Midseason.

$\$ 1.00$

LILLIAN GUMM (Gumm). This comparatively new seedling has already proven its worth both in the garden and on the show table, and is destined to become one of the outstanding varieties of the future. The flower is very large, globular, rose type, with broad, laciniated petals that grow shorter toward the center of the flower, forming a huge, ball-shaped bloom with a cupped center. In color, it is the same apple-blossom pink that we have in La France, shading lighter at the tips of the petals and with a fiery carmine-pink tint at the base that lights up the otherwise delicate pink color effect most gloriously. The plant is medium tall, and vigorous with upright stems that amply support the large blooms. A very reliable, free bloomer in late midseason, and very fragrant. The flowers last long and hold their color better than most of the light pink varieties, even in the bright sun. Handled as show blooms, they may be developed to wonderful flowers, both in size and coloring. We recommend Lillian Gumm as being one of the most promising new seedlings we know.

$\$ 10.00$

LIVINGSTONE (Crousse 1879) 8.1. This large, very compact flower is perfect rose type; and the imbricated petals are uniform, pale lilac-rose, silvery tipped; center petals flecked with carmine. The plant-growth is strong and vigorous, with good sturdy stems. Both the buds and flowers are of large size and good form. A free bloomer and late. One of the best late varieties available at a popular price.

$\$ 1.00$

LONGFELLOW (Brand 1907) 9.0. Most keen color critics agree that in Longfellow we have the nearest approach to the desired pure red Peony. The flower is high, compact, semi-rose form in which the center petals are symmetrically arranged and the guards slightly reflexed. In color, it is the brightest crimson with a cherry tone and without the violet hues that are objectionable to so many. When planted with all the best red Peonies, Longfellow stands out distinctly as the most brilliant of them all. The plant is tall and vigorous with strong, upright stems and pleasing foliage. Late midseason. A desirable variety for landscape use as well as garden planting. We quite agree with Mr. George $\mathrm{H}$. Peterson, who values Longfellow along with Karl Rosenfield as the most desirable reds now in commerce at reasonable prices. 


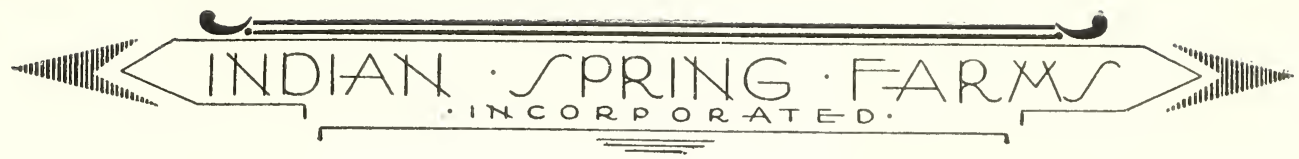

LORA DEXHEIMER (Brand 1913) 8.4. Each year this variety stands higher in our estimation, and we now rate it close to Longfellow as one of the most desirable of the Brand reds. It is an early midseason bloomer of flat, semi-rose form in which the petals are so arranged as to almost completely conceal the stamens. The flowers are symmetrically formed and have a refined and finished style that is rare in the red varieties. In color, it is intense crimson, shading darker at the base of the petals. A free and reliable bloomer on established plants, but does not come in best form until three or four years old. Medium tall, upright habit.

$\$ 2.00$

LORCH (Goos \& Koenemann) 8.7. This desirable Peony is not yet widely known, but we believe it will soon be recognized as one of the very finest late whites. The flowers are very large and high built and are true rose type with the outer petals broad and imbricated. On opening, it is beautifully flushed blush-pink, but changes to purest white. It blooms late, along with Enchanteresse, and opens more reliably. The plant is medium strong and vigorous.

$\$ 5.00$

LORD KITCHENER (Renault 1916) 7.8. Its large, loose, bomb-type flowers are bright cherry-red, with broad guard petals prominent and reflexed. The center petalage is typical bomb form but rather scarce, and the center opens loosely. A very free bloomer on a plant of medium tall growth and good habits. As a landscape plant, it is a brilliant and pleasing variety. An early description of this flower stated that it is an early variety - the earliest of all the Chinese Peonies to bloom-and this has been promiscuously copied into many later descriptions. As a matter of fact, it is a midseason bloomer, coming after many early varieties are gone.

$\$ 1.50$

LOVELINESS (Hollis 1907) 8.8. These large, flat, rose type flowers come very late instead of in midseason as frequently stated. The well-formed buds open slowly into perfectly formed blooms of uniform hydrangea-pink, changing to lilac-white. Fragrant. The growth is medium tall and upright with good strong stems. A beautiful flower that opens at the very close of the season along with Dorchester and Galathee.

$\$ 2.50$

LUELLA SHAYLOR (Shaylor 1917). A large flower with broad, differentiated guard petals of pure white enclosing a dome-like center of white petals that are distinctively tinted yellow on the midribs, giving the blooms an effect of creamy yellow. A free bloomer in midseason on a plant of excellent upright habits. On well grown plants the flowers are very beautiful.

$\$ 10.00$

LUETTA PFEIFFER (Brand 1916) 8.7. This large, semi-double flower has its broad petals loosely arranged and intermingled with stamens in such a way that the golden reflection through the white flower, suffused blush-pink, creates a charming color effect. The plant is tall and vigorous in growth, and the stems are long and strong. An early bloomer. How Mr. Brand, after trying out this variety in his seedling beds for several years, finally sold the entire stock of it, then later bought back plants when he realized he had let a valuable seedling get away from him, makes an interesting story in his own catalog description.

$\$ 5.00$

MABEL L. FRANKLIN (Franklin 1920) 9.0. The large, globular, crowntype flower has a refined style and delicate coloring-outer petals soft light pink, center of longer petals of deeper pink slightly edged lavender. 


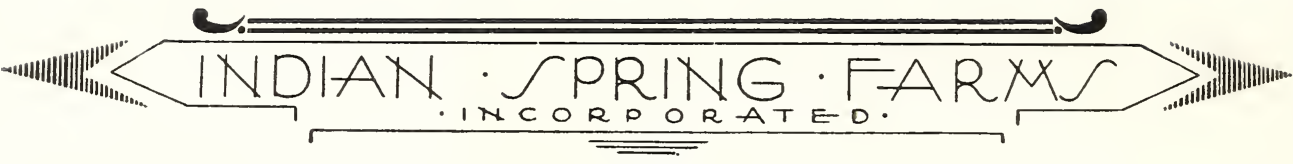

MABEL L. FRANKLIN (continued)

A collar of short, creamy petals surrounds the center and adds to the delicate color effect. Delightfully fragrant. The plant is medium tall, upright in habit, with good stems that gracefully carry the large flowers. This has, so far, proved to be the most popular of the Franklin seedlings.

$\$ 7.50$

MARCELLE DESSERT (Dessert 1899) 8.2. A refined flower that has fine form and unusual beauty. It is large in size, with broad, prominent guards, and the center is built into a high, conspicuous crown. The color is uniform milk-white, minutely spotted lilac, with the extreme center flecked crimson. A midseason variety, a free bloomer, and very fragrant. The plant-growth is strong and upright, with good stems.

$\$ 1.50$

MARECHAL VAILLANT (Calot 1867) 7.5. Syn. Souvenir de Auguste Miellez. This old Peony does not measure up in quality with the more recent introductions but is still widely grown in cut-flower plantings. The blooms are large and compact and of globular rose form, with heavy petals symmetrically placed. The color is deep mauve pink. The growth is tall and vigorous but the immense flowers that open late, are too heavy for the long stems, and the plants need support.

75 cts.

MARGUERITE GAUDICHAU (Millet 1903) 8.1. A beautiful late variety that produces delicate shell-pink flowers of fine form. The petals are slightly incurved and are interspersed with an irregular ring of partially transformed yellow staminodes. Fragrant.

$\$ 2.50$

MARGUERITE GERARD (Crousse 1892) 8.4. This large flower opens in semi-rose form, very broad and flat, with a conspicuous ring of stamens that blackens and mars its beauty for a time. As the bloom develops, the petals lengthen and a crown is formed that completely conceals the stamens, making a most pleasing bloom. The color is pale hydrangea-pink, changing to creamy-white, with central petals minutely flecked dark carmine. A free bloomer in late midseason and a strong grower of medium height and spreading habit.

$\$ 1.00$

MARIE (Calot 1868) 8.1. A semi-rose type flower with compact petalage and flat form. The color is lilac-white, changing to milk-white, tinted yellow at the base of the petals. A ring of interspersed, narrow golden petals gives life to the coloring. Fragrant. The plant is very tall, medium erect, with strong, upright stems, and blooms late.

$\$ 1.00$

MARIE CROUSSE (Crousse 1892) 8.9. This large, loose, bomb-shaped flower has a place among the finest Peonies on account of its delightful color-a most exquisite shade of uniform salmon-pink with a life and freshness about it that is not equaled in any other Peony. The plant is medium tall, with slender but strong stems. Midseason.

$\$ 2.00$

There are a number of Peonies that are healthy and vigorous in growth and flower well, yet seem to lack the rugged constitution that we have in such varieties as Le Cygne or Festiva Maxima. This is evidenced by their more slender stems, smaller and more thinly set foliage, smaller bud formation, etc. We have a habit of thinking of such varieties as "effeminate" Peonies. Marie Crousse is such a variety and Tourangelle is another.

MARIE JACQUIN (Verdier) 8.3. To those who know it well, this is about the most interesting and most charming Peony in the world. It is distinctly different from any other and has a way of coming in a variety of forms that is most bewitching. It is best described as a large, globular, semi-double flower, but on young plants it often comes as a cup-shaped 


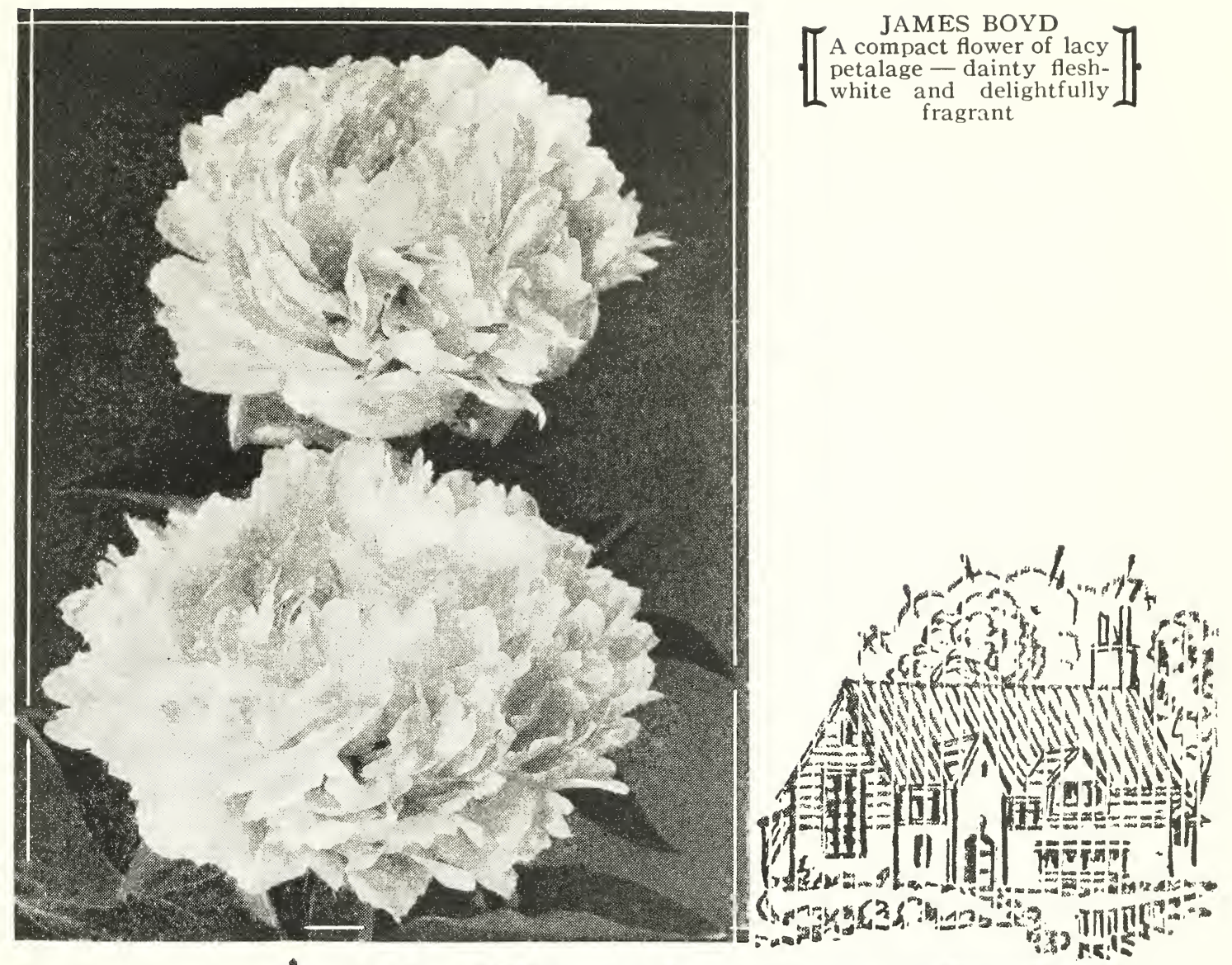

$\llbracket\left[\begin{array}{c}\text { MME. EMILE GALLE } \\ \text { A beautiful flower of deli- } \\ \text { cate tints; medium tall } \\ \text { and a strong grower }\end{array}\right\rceil$

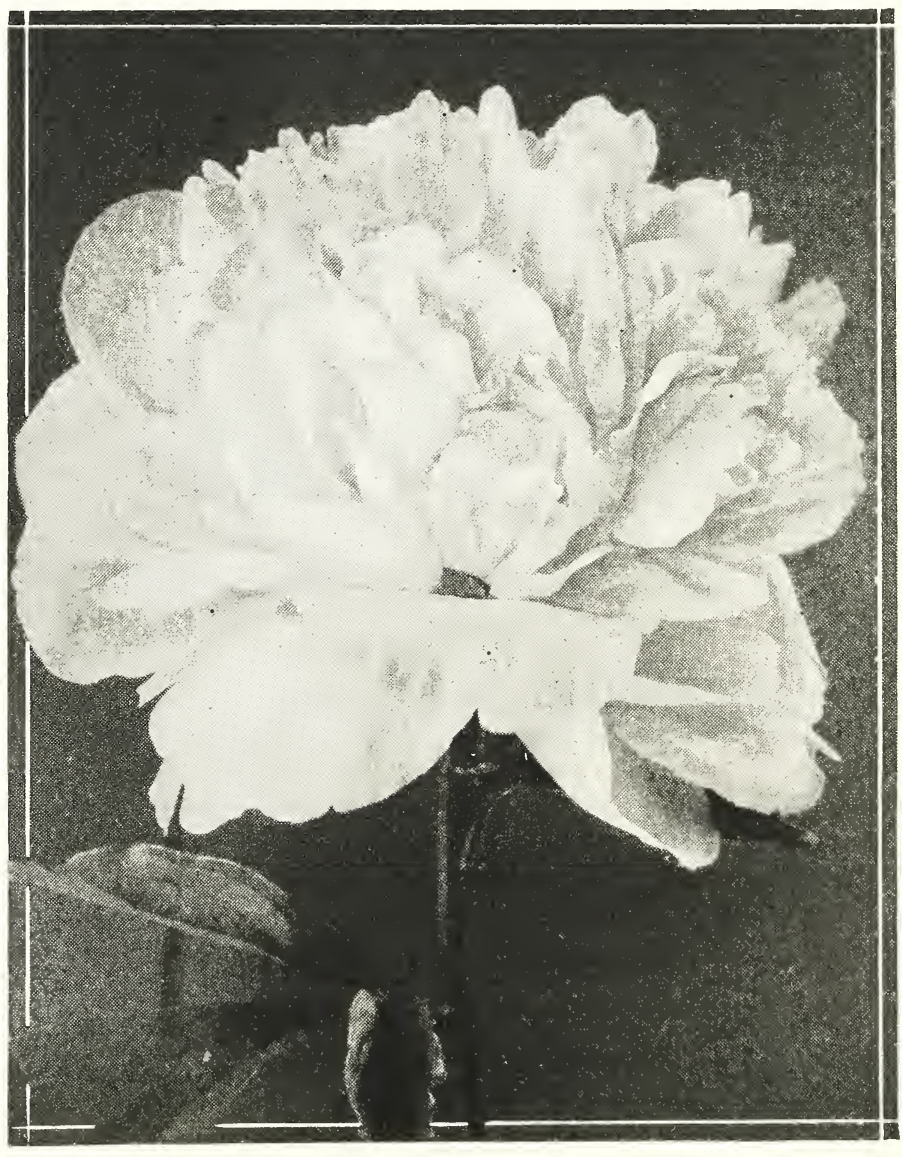




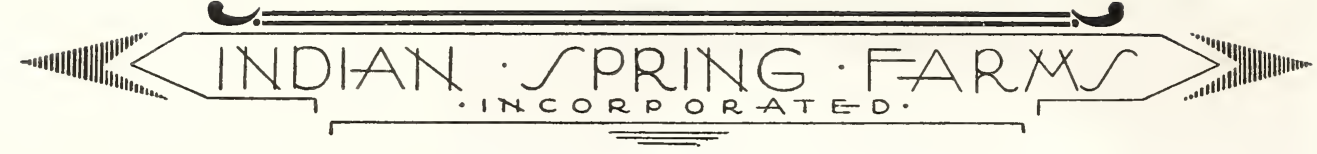

\section{MARIE JACQUIN (continued)}

single. Again, on mature plants and under good cultivation, it develops to a very large, flat, rose-formed flower with a petalage of the finest texture we ever have seen in a Peony. It is a free and reliable midseason bloomer on a plant of perfect habits and strong stems. The flowers come in clusters and, when not disbudded, the laterals open before the terminal flowers fall, literally covering the plant with the profusion of blooms. When disbudded, the flowers become very large and full. On first opening and for several days they hold a cupped form that is very pleasing, and from which the variety derived its name "Water-lily Peony." The color is a most delicate flesh tint that gives way to lilac-white as the flowers age.

See "Backbone" Collection, page 84.

MARIE LEMOINE (Calot 1869) 8.5. A very late flowering variety that is accepted as a standard by which the merits of many newer Peonies are gauged. It is a wonderful flower of large, very compact, rose form. The color is pure white, shading to cream-white in the center, with slight carmine markings on occasional petals. Its long, laciniated petals grow shorter toward the center; concealing short linear petals of sulphuryellow that light up the cupped center of the flower with a yellowish reflection. Fragrant. A rather dwarf plant with extra-strong stems.

$\$ 1.00$

MARIE STEWART (Calot 1856) 7.8. This is one of the old varieties so often found in old homestead plantings along with Fragrans, Humei and Whitleyi. A medium-sized flower of crown type; guard petals pale pink, well differentiated; collar of narrow yellowish petals, widening toward the center; crown of wider petals, flecked with crimson, that surround the narrower short petals in the center of the bloom. A plant of weak growth and spreading habits. Midseason.

75 cts.

MARTHA BULLOCH (Brand 1907) 9.1. One of the very few Peonies in which we find fine quality and texture, together with large size. This flower is cupped rose type, often measuring 9 to 12 inches in diameter. In color it is a silvery shell-pink at the edges, shading to deep rose-pink in the center, making a color effect that is delicate yet strong enough to be in keeping with the immense size of the bloom. The plant is tall, vigorous, and strong, and the stout stems hold the heavy flowers well above the foliage. A fine landscape variety and one of the greatest show flowers. The demand usually exceeds the supply.

$\$ 7.50$

MARY BAKER EDDY (Hollis 1910) 7.5. A large flower of flat rose type that is borne on a dwarf but sturdy plant. The color is soft rose-pink that changes to white with heliotrope shadings. A free bloomer in midseason.

$\$ 3.00$

MARY BRAND (Brand 1907) 8.7. This large, semi-rose type flower comes in midseason, and is a vivid crimson with a silvery sheen that gives it

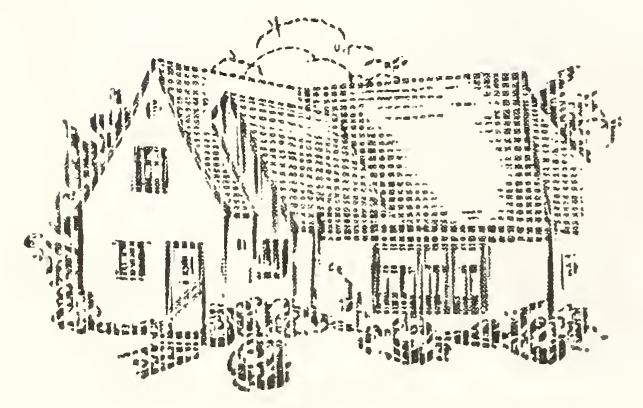
great brilliance. In color, it is not as bright as Longfellow, but the flower is larger. The blooms last long both on the plant and as a cut-flower. It is a medium-tall grower, with good habits and good strong stems. A good landscape plant as well as a good cutting variety.

$\$ 1.50$ 
MARY B. VORIES (Vories 1924). This large, semi-rose type flower opens in globular form with a flat top, like Mignon, and is pure white. It is a late bloomer on fine, strong stems. Judge Vories describes the variety as similar to his Laura Vories, except that it is white and more open in form.

MARY P. KING (Franklin 1920) 8.7. A large, globular, semi-double crown type flower; guards broad and well differentiated; collar of irregular, narrow, laciniated petals with intermingled golden stamens surrounding a high cupped center of broad petals. The color is uniform light rosepink, shaded deeper at the center, with crimson markings on the broad petals of the center band. It is a free bloomer; mildly fragrant. A plant of good upright habit with strong stems and attractive foliage. We can recommend this new seedling either for landscape or garden planting. $\quad \$ \mathbf{5 . 0 0}$

MARY WOODBURY SHAYLOR (Shaylor, 1916) 9.0. A dwarf-growing variety that is a real aristocrat. It rarely grows over 2 feet high, is very erect, and has heavy, dark green foliage set low upon very strong stems. Its flowers are very large, flat, semi-rose type, with broad, incurved guards of soft shell-pink. The center is flesh, shading to creamy-yellow at the heart, with golden lights at the base of the petals reflected from concealed stamens. Midseason. A very beautiful variety desirable for any planting.

$\$ 6.00$

MASTERPIEGE. Syn. Mr. Manning (Kelway 1895) 7.4. A large, freeblooming variety that furnishes a profusion of blooms in early mid-season. The flowers are semi-double, dark Tyrian-rose in color, with the stamens intermingled throughout, and slightly fragrant. A fine, tall plant with good stems. This is one of the reds that cannot stand the hot sun. $\mathbf{\$ 1 . 0 0}$

MATHILDE DE ROSENEGK (Crousse 1883) 7.9. A late-blooming variety with large, full, double flowers of globular form. The broad outer petals are pale lilac-rose, and the center petals narrower, shading to deep carminerose. Delightfully fragrant. The plant is very tall and vigorous in growth, with long stems that have a habit of coming crooked and spreading. The flowers are very pleasing but we cannot say as much for the habit of the plant.

$\$ 1.00$

MATILDA LEWIS (Saunders 1921) 9.0. This is a worthy red Peony that is not yet widely known. The flower is compact, semi-double type of rich dark crimson color, nearly as dark as M. Martin Cahuzac but with a redder color tone. The blooms open in late midseason on a plant of pleasing growth and habits.

$\$ 25.00$

MAUD L. RIGHARDSON (Hollis 1905) 8.5. This Hollis variety seems to be growing in favor and is in greater demand each year. The flower is large, medium compact, flat, rose type, with good even color and pleasing petalage. Its guards and outer petals are clear lilac-rose, shading lighter toward the center. A late, free bloomer and very fragrant. The growth is tall, strong, and vigorous, with good stems.

$\$ 2.00$

Peonies are naturally slow in growth, and new varieties in the hands of commercial growers are so divided for intensive propagation that it is sometimes many years before really good sorts are given opportunity to become thoroughly established and prove their merits. So it happens that in the flood of new varieties that have been introduced in the past decade, certain fine Peonies have been lost, so to speak, and have not received the recognition they deserve. Only by unbiased study of the older varieties are these "lost jewels" being rediscovered and brought to their own. 


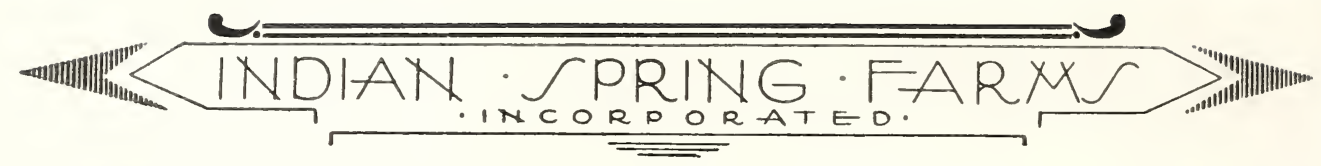

MIDNIGHT (Brand 1907) 7.3. If this red peony had substance enough in its petals to better endure the hot sun, it would be one of the most popular varieties. The flowers are very large, semi-double, with broad petals of rich, dark red. They open early on a tall, graceful plant and always attract much attention, but unfortunately they do not hold well in the sun and wind.

$\$ 1.00$

MIDSUMMER NIGHT'S DREAM (Pleas 1906) 8.2. A medium to large flower of crown form, with ivory-white guards and center petals of good substance. The wide collar of narrower petals is primrose-yellow, which produces a charming color effect. It is of healthy, vigorous growth but of spreading habit, and the plant must be amply supported to protect the blooms.

$\$ 1.50$

MIGNON (Lemoine 1908) 8.7. One of the most charming of all M. Lemoine's wonderful varieties. The large, compact flower is of globular, semi-rose type and the petals are broad, imbricated, and symmetrically arranged. They open into large, flat-topped, ball form, developing to a flat flower, and the color is lacy white, changing to amber-cream, with the center petals flecked carmine. The plant is medium tall, very erect, well set with luxuriant light green foliage, and the stout stems support the flowers perfectly. Midseason. This variety has a reputation of being a shy bloomer, but that is because much of the stock is diseased. On healthy roots it blooms freely and each year it develops perfect flowers on almost every stem.

$\$ 4.00$

MILTON HILL (Richardson) 9.0. This late-blooming variety is one of the very finest Peonies. Its flowers are very large, delicately colored, and have refined texture. The broad petals are slightly incurved and open in globular, cupped form, developing to a large, flat flower of perfect roseshape. It is pale lilac-rose, or flesh, with opalescent tints of delicate salmonpink. The plant is strong, medium height, with sturdy stems, and is desirable for landscape or garden. To those who appreciate perfect form, delicate beauty and refinement in a flower, we cannot recommend it too highly. At the Des Moines National Peony Show, a fine bloom was awarded the prize for the finest flower in the show.

$\$ 3.50$

MIREILLE (Crousse 1894) 7.7. A very large, compact, globular, rose type flower, and one of the very latest whites to bloom. The color is milkwhite, with the broad center petals edged crimson. It is a very fine cutflower and very fragrant. The plant is tall, strong, and vigorous. In the cool climate of the North, this is a desirable variety, but in the South it is not reliable and does not open well.

$\$ 1.00$

MISS SALWAY (Kelway) 7.8. This is one of the most beautiful Peonies we have, yet because it has been unfortunately mixed in commerce with the variety Solfatarre, it is accredited with a low rating. The true variety is typical crown type. The guards and the center are delicate flesh-pink and the collar of irregularly notched smaller petals is creamy white. Delightfully fragrant. The plant is medium tall and vigorous, with sufficiently stiff stems to carry the flowers gracefully. A desirable variety for either landscape or cut-flower planting. Midseason.

$\$ 5.00$

MLLE. JEANNE RIVIERE (Riviere 1908) 8.2. A perfectly shaped flower of medium bomb form. The light flesh-pink guard petals are broad and prominent, and the center is a medium-high dome of narrower incurved petals that open a light canary, changing to sulphur-white. 


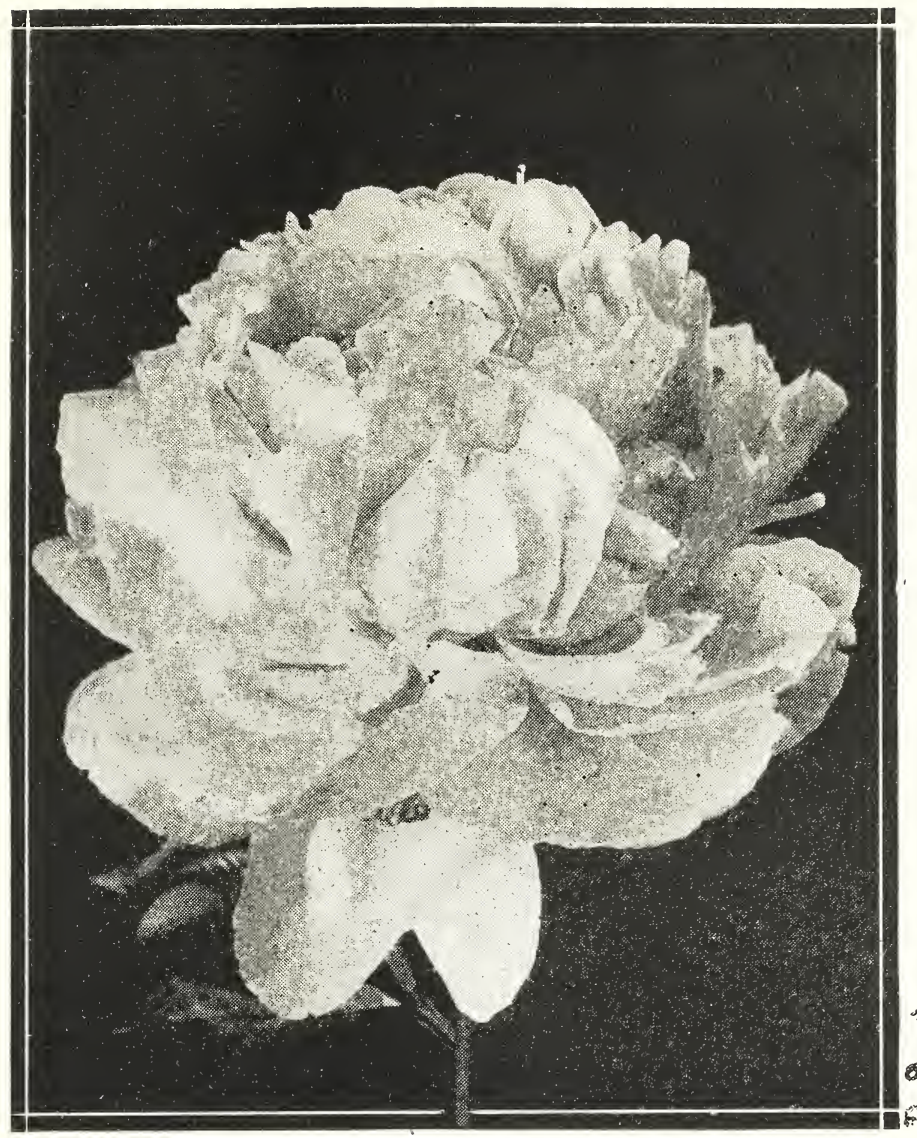

$\llbracket\left[\begin{array}{c}\text { KATHARINE } \\ \text { HAVEMEYER } \\ \text { A soft lilac pink. A large } \\ \text { flower of refined form, } \\ \text { very fragrant }\end{array}\right\rceil$
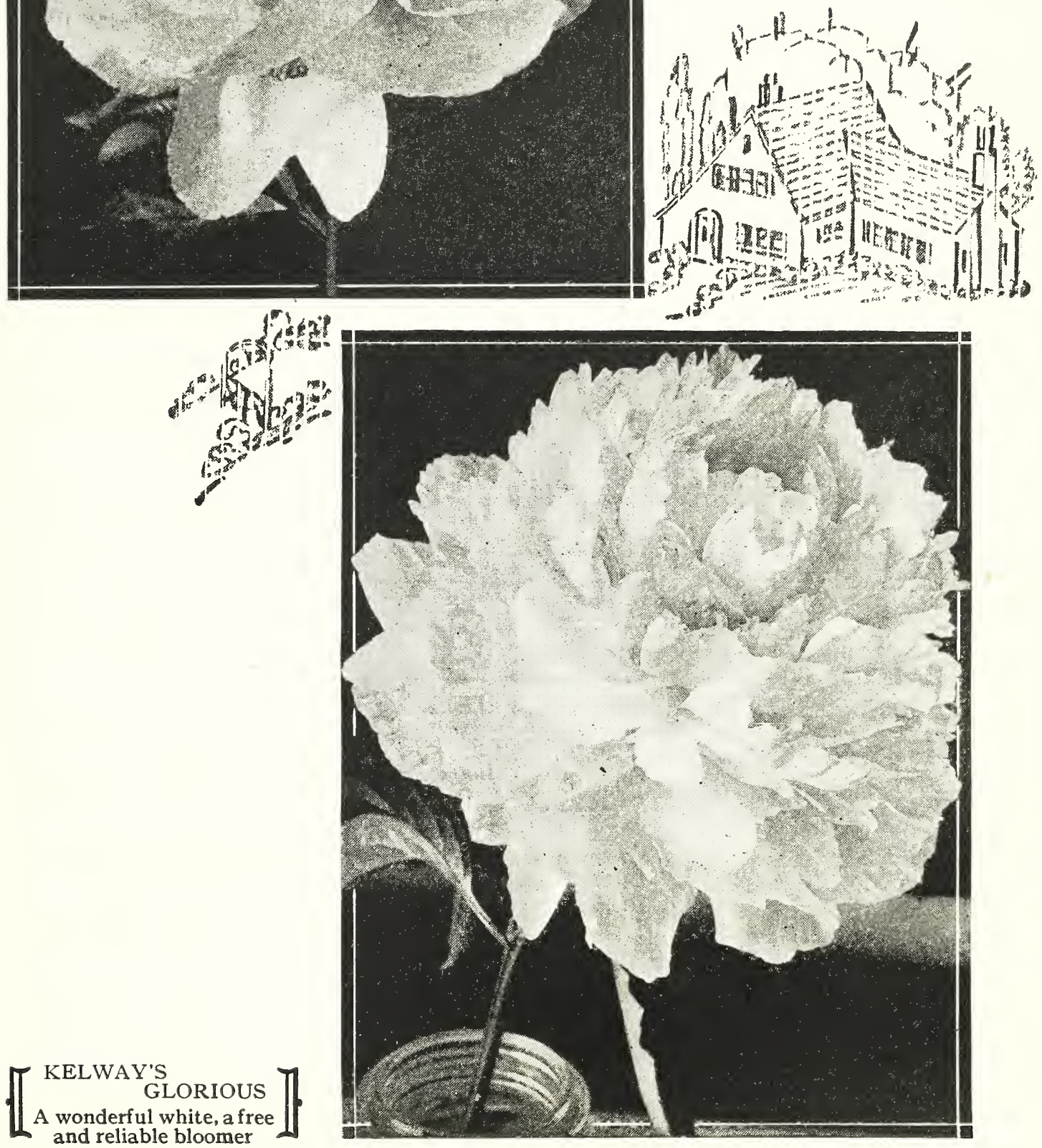


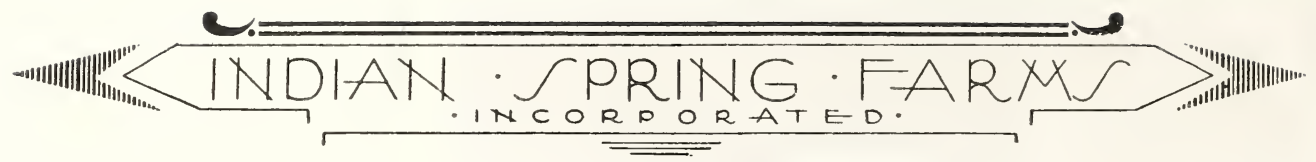

\section{MLLE. JEANNE RIVIERE (continued)}

Delightfully fragrant. The plant is a tall grower, upright, and with strong stems that support the flowers in a way that makes this a desirable landscape Peony as well as a garden plant. Its blooms are frequently seen on the show table, and the variety is gaining in popularity as it becomes better known.

$\$ 2.00$

MLlE. LEONIE GALOT. Syn. M. Charles Leveque (Calot 1861) 8.1. This Peony will appeal to those who appreciate real beauty in a flower rather than size. It is a true rose type bloom of medium size, very delicate rose-white, shaded deeper lilac-pink toward the center, with center petals slightly tipped carmine. A delicately colored flower with a charm that is irresistible. The plant is medium tall, with stems that droop gracefully under their burden of blooms. A delightful cut-flower variety but hardly robust enough for the landscape.

$\$ 1.00$

MLLE. ROUSSEAU (Crousse 1886) 8.1. Its large, full, semi-rose type flowers have fine form and substance. The guard petals are milk-white, splashed carmine, center of broad petals sulphur-white flushed lilac, and there are a few carmine markings on the extreme center petals. Plant is medium tall, strong and upright in growth, and has good sturdy stems. A free midseason bloomer.

$\$ 1.50$

MME. AUGUSTE DESSERT (Dessert 1899) 8.6. Its large, semi-rose type flowers open flat, with a conspicuous ring of golden stamens, then develop to a semi-globular form. In color, it is a uniform violet-rose with guards and center marked with carmine. An erect plant of medium height with strong stems and well-set foliage. A good, free-blooming, early-midseason variety, desirable either for landscape or for the garden.

$\$ 1.50$

MME. BARILLET DESCHAMPS (Calot 1868) 7.8. A large, semi-rose type flower with wide, imbricated petals. The color is clear violet-rose, changing to a delicate silvery-pink. Fragrant. The plant is of medium height with strong stems and coarse, heavy foliage. Early midseason.

$\$ 1.00$

MME. BENOIT RIVIERE (Riviere 1911) 8.0. Medium to large flower of high crown form, with guards that are broad, rounded, and very prominent, surrounding a high tufted center of broad petals of the same rosewhite color as the guards. Around the center is a very distinct collar of long, narrow, hair-like petals of clear light yellow, unlike any other petalage we know in a Peony. When opened indoors, or before the sun has opportunity to spoil the delicate color effect, the flower is wonderfully beautiful and quite distinct from any other variety. The plant is spreading in habit and should be supported.

$\$ 3.00$

MME. BOULANGER (Crousse 1886) 7.8. Very large, flat, rose type flower that comes in late midseason. The color is soft glossy pink, shaded lilac, with a silvery flesh border. A plant of sturdy, upright habit, with good, stiff stems. The lilac-pink, or heliotrope, coloring in this flower is quite distinct and greatly admired by those who know it well.

$\$ 1.00$

MME. BUCQUET (Dessert 1888) 7.3. A medium-sized, loose, semi-double flower in which the stamens are scattered throughout the center petals. Its color is uniform, dark crimson-amaranth that makes a very brilliant garden effect. The plant is a vigorous and strong grower, and flowers freely in midseason. 
MME. CALOT. Syn. Leonie (Miellez 1856) 8.1. The very large, rose type flower globular in form, and the broad guard petals, which stand out prominently, are surmounted with a dome-shaped center of smaller petals. The general color is pale hydrangea-pink, shaded darker toward the center, with a slight collar tinted silver. It is an early bloomer that comes along with Edulis Superba. The plant is strong and vigorous in growth, slightly spreading in habit, and the stems are long and strong, each bearing a cluster of flowers that are delightfully fragrant. A very valuable cutflower variety that is worthy of a place in any garden. The old variety Queen Victoria has been widely sold as Mme. Calot, and many very good collections do not have the true variety.

$\$ 1.00$

MME. CAMILLE BANCEL (Crousse 1897) 7.9. A tall, strong variety that bears its large, globular, rose type flowers on long, stiff stems. The color is uniform deep pink, or solferino-red, with a silvery reflex. Very fragrant. Late.

$\$ 1.00$

MME. CROUSSE (Calot 1866) 7.9. Its flowers are medium to large in size, globular crown type, and the prominent guard petals and a few of the collar petals reflex to the stem on well-developed blooms. In color, it is uniform pure white, with the center petals occasionally flecked crimson. The plant is of medium height and slightly spreading habit, with strong stems. One of the best of the older white Peonies that is worthy of a place in any garden and suitable for landscape use.

$\$ 1.00$

MME. DE GALHAU (Crousse 1883) 7.5. A medium-large, compact, rose type flower of globular form, with guards rose-white and center pale lilac-rose. It is a late variety and very fragrant. The buds are poor and often become water-logged, making the plant unsightly for a time, but the well-developed flowers are very beautiful.

$\$ 1.00$

MME. DE VERNEVILLE (Crousse 1885) 7.9. This early white variety is very sweetly fragrant and of pleasing form. It is very full bomb type, pure white, with center delicately tinted blush when the flower first opens, changing to all pure white except for four distinct crimson marks on the tips of the center petals. The plant is medium in height, a medium-strong grower, and an extra-free and reliable bloomer. In the cool climate at Duluth, this variety is at its best, being one of the largest and most perfectly formed of all the white Peonies.

$\$ 1.00$

MME. D. TREYERAN (Dessert 1899) 8.2. The very large, flat flower of compact semi-rose form is rose-white, thickly speckled with minute dots of lilac, and has the center petals marked crimson. It has the same speckled appearance we have in Asa Gray, and is very fragrant. A free bloomer in midseason. The plant is very erect in habit, medium tall, with good, strong stems. Good either for landscape effects or general garden planting.

$\$ 2.00$

MME. DUCEL (Mechin 1880) 7.9. A typical bomb-type flower of perfect form, coming in midseason. The guard petals are broad and prominent, surmounted by a chrysanthemum-like center of narrow, compact, incurved petals, and the whole flower-both guards and center-is light mauve-rose with a silvery reflex. It is a

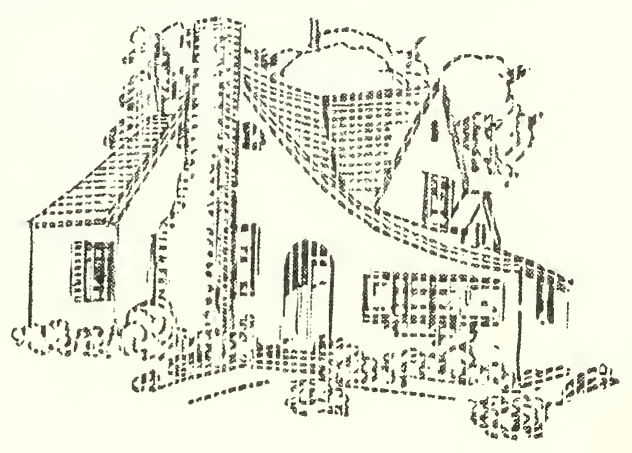




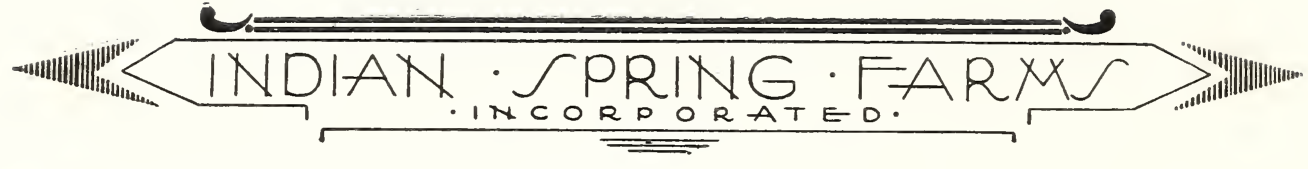

\section{MME. DUCEL (continued)}

vigorous, upright grower of medium height and is very floriferous. The blooms hold their color and perfect form to the end. A good variety for either cut blooms or landscape use.

$\$ 1.00$

MME. EMILE GALLE (Crousse 1881) 8.5. Its large, flat flowers are rose type and open in late midseason with about the daintiest colorings to be found in a flower-translucent lilac-white, with an opalescent shading of shell-pink, changing to milk-white in the center. The outer petals are broad and imbricated, with a center of broad petals very delicate in texture. It is medium tall and a strong grower, with good stems. A very free and reliable bloomer.

$\$ 1.00$

The first time we ever met the late Mr. Bertrand Farr, we called on him in his office at Wyomissing. On his desk, that afternoon, was a very fine single bloom of Mme. Emile Galle, which was about the most delicately beautif ul flower we had ever seen. We later came to know Mr. Farr quite well, and we now like to remember him as a man who could best express his appreciation of beauty by the selection of a Peony of such ethereal loveliness.

MME. EMILE LEMOINE (Lemoine 1899) 8.9. One of M. Lemoine's varieties that deserves a place among the very finest of his wonderful Peonies. It is a very large flower of full, semi-rose type that develops to a flat, saucer-shaped bloom. The buds are very large and distinctively striped carmine. On first opening, the broad, imbricated petals of purest white are suffused with a sheen of soft pink that is most delightful, but as the flower ages they become clear white. Center petals are irregularly marked carmine. The plant is vigorous in growth, with good strong stems, and is a free and reliable bloomer. Midseason. There is a delicacy of charm about a fine, well developed bloom of Mme. Emile Lemoine that cannot possibly be expressed in words.

$\$ 1.50$

MME. FOREL (Crousse 1881) 7.7. If size were everything, this Peony would rate near the top. The flowers are very large, compact, rose type, with wide imbricated petals of violet-rose having a silvery sheen and tipped silver. It is a late bloomer that does not come good every year. In growth, it is medium tall, strong, and vigorous, but with a spreading habit and with stems that cannot support the mammoth blooms when they open well. The blooms are very fragrant and are very good for cut-flowers.

$\$ 1.00$

MME. GAUDICHAU (Millet 1902) 8.8. This is a most interesting Peony that would be worth growing for its foliage alone, even if it never bore a flower. As the young plant comes out of the ground in the spring, it is very dark red and holds this distinct red color even after the leaves unfold, and until the flower-buds are well developed. Again in the fall, the plant turns red even before the frosts change the other vegetation. The flowers are large, loose, semi-double, of irregular form, and are a shade of very dark maroon that does not burn or fade. A medium bloomer in late midseason.

$\$ 5.00$

MADAME GEISSLER (Crousse 1880) 7.9. A very large flower of compact globular, rose form. The imbricated petals are deep violet rose, shaded to silver at the tips, making a bloom of pleasing form and dark pink color that appeals to those who admire big flowers. A free bloomer in midseason on a plant of spreading habit. A desirable cut-flower variety and very fragrant. 


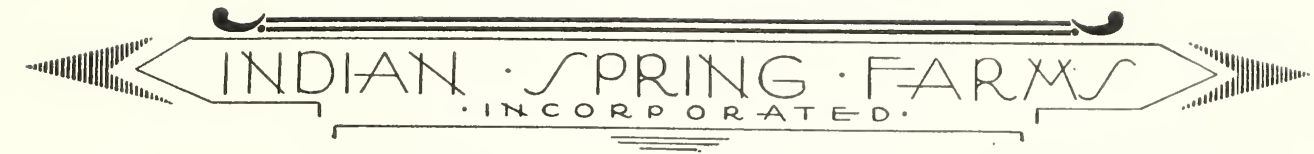

MME. JULES DESSERT (Dessert 1909) 9.4. When we describe this as a very large, flat, semi-rose type bloom, the words inadequately convey an impression of it. It is a flower that is hard to do justice to in words. The tall, vigorous plant blooms freely in late midseason on strong stems, and the flowers invariably open perfectly. In general effect, the large, flat, saucer-shaped flowers are delicate flesh-pink, shading to straw-white, with a golden glow in the center reflected from the golden stamens. The broad petals are imbricated and undulated in a distinctive style, and the center petals are occasionally marked carmine.

$\$ 2.50$

MME. LEMOINIER (Calot 1865) 8.0. This is another of the older Peonies that still rates well as a landscape plant and is also desirable for cutting. Its blooms are large, compact rose type, pale lilac-rose that fades to lilacwhite as the flowers age. The center petals are almost as wide as the guards, and are occasionally flecked with crimson. A tall, vigorous grower of fine habits. Late midseason.

$\$ 1.00$

MADAME MANCHET (Dessert 1913) 8.5. This is a desirable deep pink that blooms at the very close of the season. The flowers are large, full, rose type, with the petals perfectly imbricated. The color is similar to Sarah Bernhardt, a soft mauve pink that shades lighter to silvery lilac at the tips of the petals. A vigorous plant with medium stems.

$\$ 2.00$

MME. MECHIN (Mechin 1880) 7.3. A dark red variety that affords a show of brilliant color early in the blooming season. The flowers are medium size, compact semi-rose form, with the stamens almost wholly concealed in well developed blooms. Deep purple-garnet. The plant is medium tall with slender but strong stems.

$\$ 1.50$

MME. SAVREAU (Savreau 1906) 7.7. All early flowering Peonies that give a profusion of blooms when they are most wanted are very desirable. Mme. Savreau is a desirable Peony on that account. The flowers are large, globular, crown type, with guards and center lilac-white and the collar deep cream-yellow. The guards are broad and well differentiated, and the center petals are broad and long and arranged in tufted form, making a bloom of pleasing style. The plant is tall, upright and compact.

$\$ 2.00$

MODELE DE PERFECTION (Crousse 1875) 7.8. A large, compact flower of pyramidal rose form, very symmetrical. The guards and collar are the same shade of light violet-rose, silvery tipped, and the center of very wide, high petals is shaded darker. A medium dwarf plant and a free bloomer.

$\$ 1.00$

MODESTE GUERIN (Guerin 1845) 7.8. A typical bomb-type flower of light solferino-red that comes in early midseason. Fragrant. A strong plant of medium height with good stems that hold the blooms well upright. This is the best of the early deep pink varieties. Equally good for the landscape or for cut-flowers.

$\$ 1.00$

MONSIEUR DUPONT (Calot 1872) 8.3. This large, flat, semi-rose type flower is quite similar to Boule de Neige, but later. The well-formed cupshaped bloom is cream-white, with the center petals conspicuously splashed crimson, and with golden stamens lighting up the base of the petals. It is a tall, vigorous plant with good strong stems, and a free bloomer in midseason. One of the thoroughly good Peonies that has a place in every wellselected collection. 
MONSIEUR JULES ELIE (Crousse 1888) 9.2. Next to Festiva Maxima, this is the highest rated of all the older varieties. It is truly a sensational flower - the largest and the most striking of the pink Peonies. Its enormous, very full flower is globular crown type. The guards are large and prominent, and the center is an immense ball of imbricated petals incurved like a chrysanthemum. In color, it is a clear, pale lilac-rose with a silvery sheen, the collar of narrow petals being lighter, tinted amber at the base. An early bloomer with pleasing fragrance. The plant is medium tall and medium strong, with a distinctive light green foliage. While the stems are not strong enough to support the immense blooms unassisted in a landscape planting, it is one of the very best for cut-flowers and keeps long when cut in bud.

See the "Four Veterans" Collection offer, page 84.

MONSIEUR KRELAGE (Crousse 1883) 7.7. This large, compact flower of semi-rose type is a distinct shade of solferino-red, with the ends of the petals tipped silver. There is no other Peony of the same shade. A strong, upright grower with good stems. Late.

$\$ 1.00$

MONSIEUR MARTIN GAHUZAC (Dessert 1899) 8.8. A large, massive semi-rose type flower of very full petalage that is outstanding on account of its dark, rich coloring and its distinctive foliage. If it is not the darkest Peony in existence, it is the darkest good one, and for that reason it is in great demand. The flower is very dark purple-garnet with a black reflex and prominent bright yellow stamens. It is medium in height, strong and vigorous, with sturdy, upright stems. The foliage is very dark, rich green, veined red. In bloom in early midseason. A striking variety for landscape planting.

$\$ 2.50$

MONT BLANG (Lemoine 1899) 8.4. This Peony has been badly mixed in commerce and many collections do not have the true variety. The flower is very large, very compact rose type, with laciniated petals giving the bloom a lacy effect. Well-developed flowers are distinctly thick and flat, of so-called "plug-hat" shape. The color is milk-white with the center slightly tinted rose. Very fragrant. The plant is medium in height and erect with stems that, though strong, are not always sufficient to support the mammoth blooms. An early midseason bloomer.

$\$ 2.00$

MOSES HULL (Brand 1907) 8.2. A large, crown-type flower with the prominent guards and the broad center petals deep rose-pink, and a conspicuous collar of cupped petals and petaloids of creamy-white. An attractive flower with delicate and pleasing fragrance. A medium tall, upright grower, with strong stems, and a free bloomer in midseason. $\mathbf{\$ 1 . 0 0}$

MRS. A. G. RUGGLES (Brand 1913) 8.3. A large flower of flat, semi-rose form. The petals are long and fringed and give the wide-open blooms a pleasing lacy finish. The color is delicate lilac-white that shades to almost pure white as the flower ages. A strong plant of good habits that flowers late. Fragrant.

$\$ 3.00$

MRS. A. M. BRAND (Brand 1925) 9.6. This beautiful Peony is the most remarkable of all the recent introductions and has been honored with the Gold Medal of the American Peony Society for its superior merit. The flower is very large, of perfect rose form, and is pure white throughout. The petals are large and uniform and of remarkable substance. The plant, itself, is as perfect as the flower, medium tall and vigorous with strong, upright stems and beautiful dark green foliage. A reliable variety that blooms very late. 
MRS. CHARLES GILBERT (Shaylor 1916). A large flower of loose, semidouble form that has the same delicate pink, or light violet rose, coloring as Therese. The blooms are gracefully carried on a pleasing plant of desirable habits. Midseason.

\begin{abstract}
There is a certain pleasing charm to peonies of the loose, semi-double form, when they are well done, that we do not find in the more compact flowers. Their delicate coloring is greatly enhanced by the reflected glow from the golden stamens, and their scant petalage lends a careless air to the flower that is appealing. Phyllis Kelway is such a peony, Shaylor's Dream, Mrs. Shaylor Force, and Mrs. Charles Gilbert are others. Such peonies only reveal their true beauty on mature plants.
\end{abstract}

MRS. C. S. MINOT (Minot 1914) 9.2. A very beautiful Peony of dwarf growth that makes a fitting companion to Mary Woodbury Shaylor. The flowers are very large and of semi-double rose form. The outer guard petals are large and uniformly shaped, tinted delicate pink, and surround the center of irregular petals of creamy-white that is lighted up with the golden lights from the concealed stamens. The center band petals are lightly marked with crimson. Growers' stocks of this fine variety are very limited.

$\$ 35.00$

MRS. EDWARD HARDING (Shaylor 1918) 9.3. A large, pure white flower of semi-rose type, having close-set petals of fine quality and pleasing form. The color is clearest white, suffused with a delicate golden reflection from the concealed petals. It is a plant of ideal habit, strong, upright and vigorous, with good stems. This Peony was awarded a prize at the $\mathrm{Na}$ tional Peony Show in Cleveland as a seedling of exceptional merit. Being high in price, the variety has suffered from over-propagation, and a portion of the stock has become weakened and diseased. It is naturally a free and reliable bloomer, and on well-established plants it shows the quality to merit the reputation it has attained.

$\$ 12.50$

MRS. F. A. GOODRICH (A. M. Brand 1925). A large, very bright pink flower of beautiful rose type form, with long, narrow petals of great substance. The plant is strong and vigorous with good upright stems. A very refined and beautiful flower that appears at its best on the show table.

$\$ 50.00$

MRS. FRANK BEACH (A. M. Brand 1925). This very large, flat, rose type flower has laciniated and lacy petals of Jubilee form. The color is purest creamy-white throughout. While the plant is dwarf in growth, it has good strong stems that hold the flowers very erect. Blooms late. Received an Award of Merit from the American Peony Society at London, Ont., in 1922.

$\$ 50.00$

MRS. HARRIET GENTRY (A. M. Brand 1925). Another fine white that is worthy to be classed with Mrs. A. M. Brand and Mrs. Frank Beach. It has a full, compact, rose type flower, with laciniated and lacy petalage, all pure white, with a greenish reflection from the heart and at the base of the petals. A strong-growing, free-blooming plant. Late flowering.

$\$ 50.00$

MRS. JENNIE R. GOWDY (Brand 1920) 7.9. Its large flowers are high, globular, rose type, and the petals are pinkish white, minutely flecked with red, like Asa Gray, and with heavy blotches of carmine on the central petals. Owing to the somewhat ruffled appearance of the petals, Mr. Brand describes it as a ruffled Peony. The plant is vigorous in growth but is unfortunate in being spreading in habit, with weak stems that detract much from an otherwise distinct variety. 


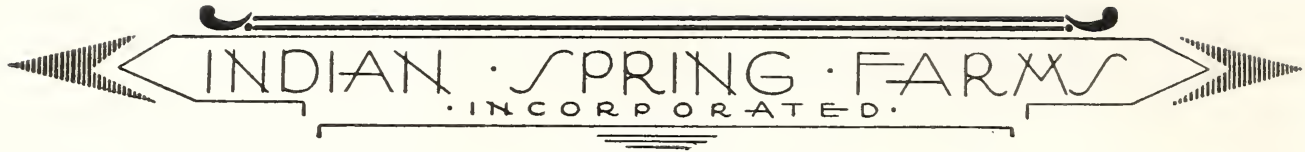

MRS. JOHN M. KLEITSCH (A. M. Brand 1925). A very fine and beautiful flower of large rose type, with petals fine in texture, long and pointed, and so arranged as to form a cupped center to the flower of fine form. The color is light violet-rose with a distinct lavender cast, and the plant is of medium tall habit and strong in growth, with good stems holding the blooms erect above the foliage. This has proved to be one of the best and most popular of this lot of remarkable seedlings.

$\$ 50.00$

MRS. JOHN M. LEWIS (Lewis 1920) 8.2. A distinct variety of exceptional merit. The large flowers of semi-rose type are variable in their development, sometimes coming with many rows of petals surrounding a center of yellow stamens, and at other times coming almost full double with the stamens mingled throughout and almost wholly concealed. An attractive shade of deep, velvety, oxblood-red that holds without burning in the hottest sun. A medium tall plant with strong, upright stems. Midseason. $\$ 3.00$

The Peony, Mrs. John M. Lewis, is a distinct and desirable variety that has proved disappointing to many because it was inaccurately described when first introduced. Growers who bought it at a high price expecting a "compact rose-type" bloom have never been able to flower it true to description. We have grown the variety since 1921, and once were privileged to see a planting of several hundred mature plants in the originator's garden. It grew there as a true semi-double flower of uniform form and rich color, showing the bright yellow stamens in brilliant contrasting effect. Had the original description been accurate when the variety was introduced, we believe it would now carry a much higher rating. The first description of a new seedling should always convey an accurate conception of the flower.

MRS. ROMAINE B. WARE (A. M. Brand 1925). In coloring, this is about the most dainty Peony we know. It is a medium-large, rose formed flower of fine texture, delicate flesh-pink, shading lighter, with a beautiful rose-bud effect in the center, shading deeper. Delicate rose fragrance. The plant is of medium tall growth but is nevertheless vigorous, producing slender and strong stems in perfect keeping with the dainty flowers they carry.

$\$ 50.00$

MRS. SHAYLOR FORCE (Shaylor 1919). This beautiful Peony is fast coming to the fore as its merits are known, and it is now recognized as one of the very finest of the Shaylor introductions. The flowers are true rose type, with long, loosely arranged petals that graduate in length to a cupped center. Its color is pure white with a light margine of carmine showing on an occasional petal and a yellow reflex at the heart from an occasional yellow petaloid. On young plants, the flowers are loose semi-double. The plant growth is strong and vigorous with good landscape habits. Midseason.

$\$ 15.00$

MYRTLE GENTRY (A. M. Brand 1925). The immense flowers are borne on a plant of ideal habits, for stiff stems hold the beautiful blooms proudly aloft. It is of perfect rose form, with broad, rounded petals, perfectly imbricated, forming a flower of pleasing symmetry with a beautiful cupped center. The color is rose-white, suffused with tints of flesh and salmon, such as we find in Tourangelle and Sarah K. Thurlow. Very pleasing fragrance. This fine flower was awarded a Silver medal by the American Peony Society at St. Paul in 1923.

$\$ 50.00$

NANGY DOLMAN (Vories 1924). This wonderful seedling of Judge Vories was awarded the Silver Medal of the Garden Club of America as the best new seedling on its first showing at the National Peony Show at Des Moines, and also second prize for the best specimen bloom in the show. It is an extremely large flower, so full and compact that it usually takes ten days to develop after the bud begins to open. The color is a beautiful soft pink, and the plant is very large and strong, with exceedingly long, stiff stems. It will, undoubtedly, prove to be one of the really fine Peonies.

$\$ 25.00$ 


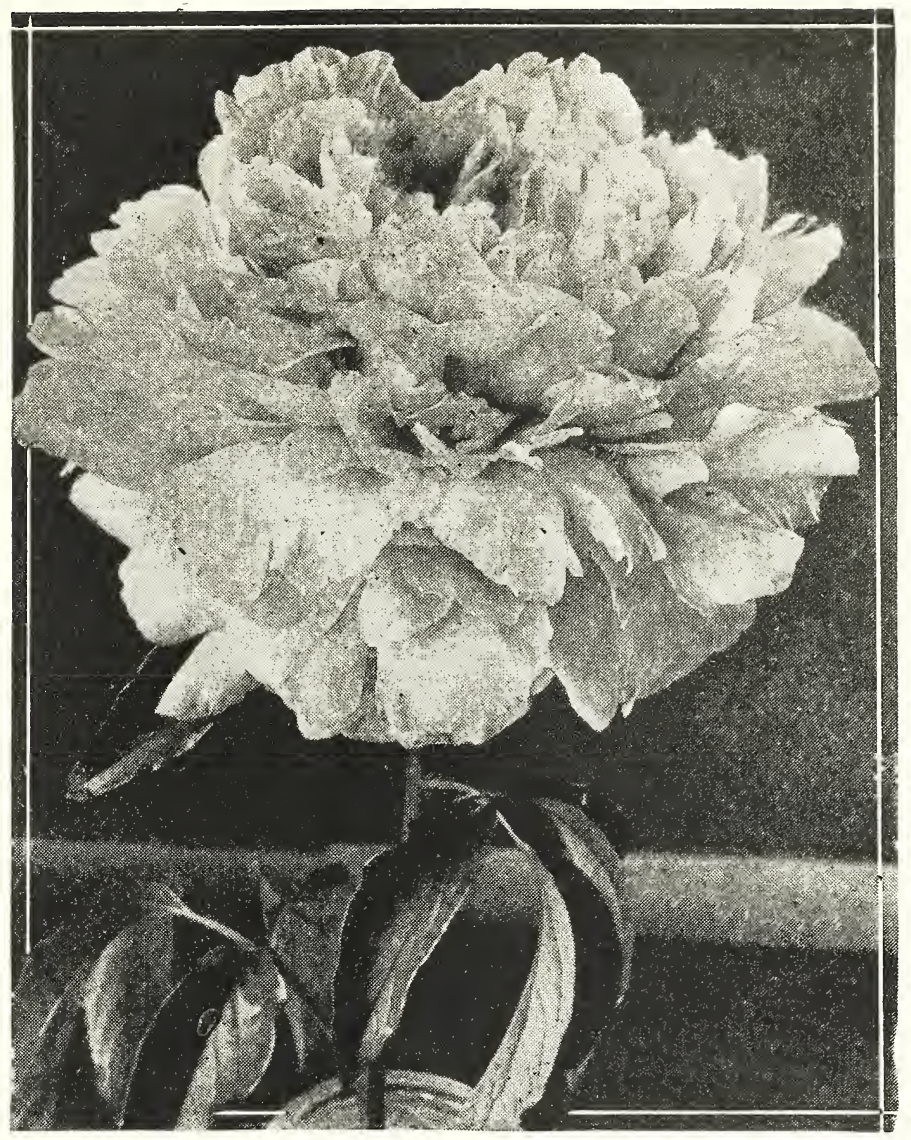

$\left\{\begin{array}{c}\text { MARTHA BULLOCH } \\ \text { A mammoth flower of } \\ \text { fine quality and texture. } \\ \text { Soft, medium pink }\end{array}\right]$
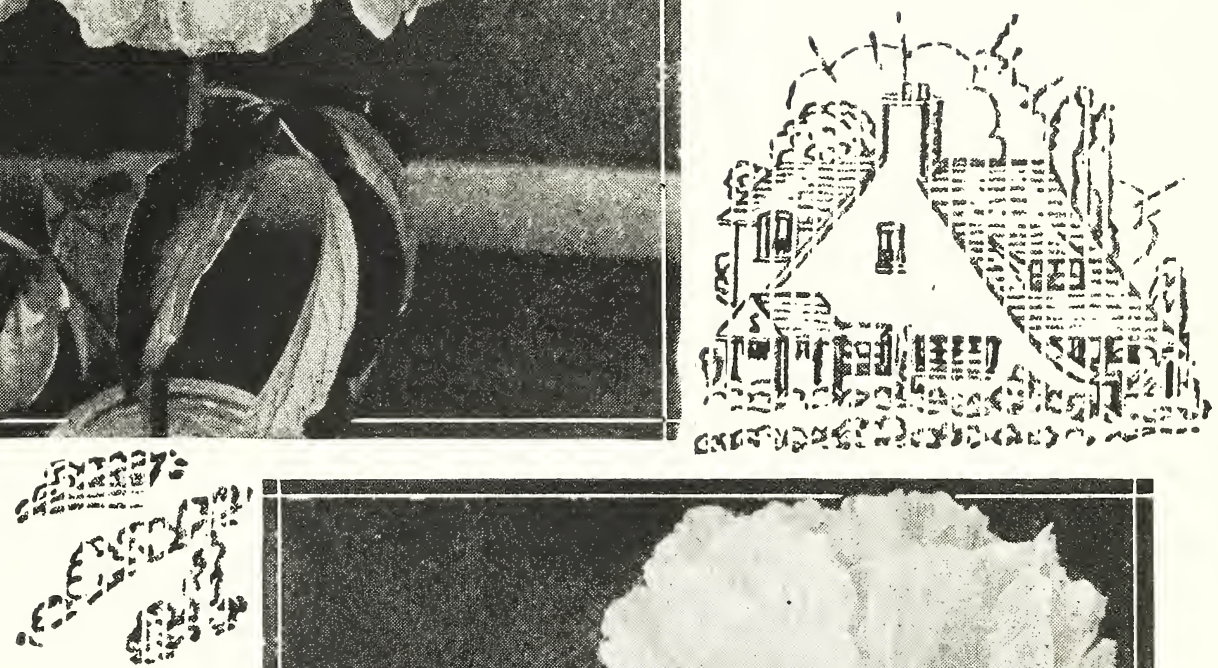

$\llbracket\left[\begin{array}{c}\text { PHOEBE CAREY } \\ \text { A delicate lavender-pink } \\ \text { of perfect }\end{array}\right\rceil$

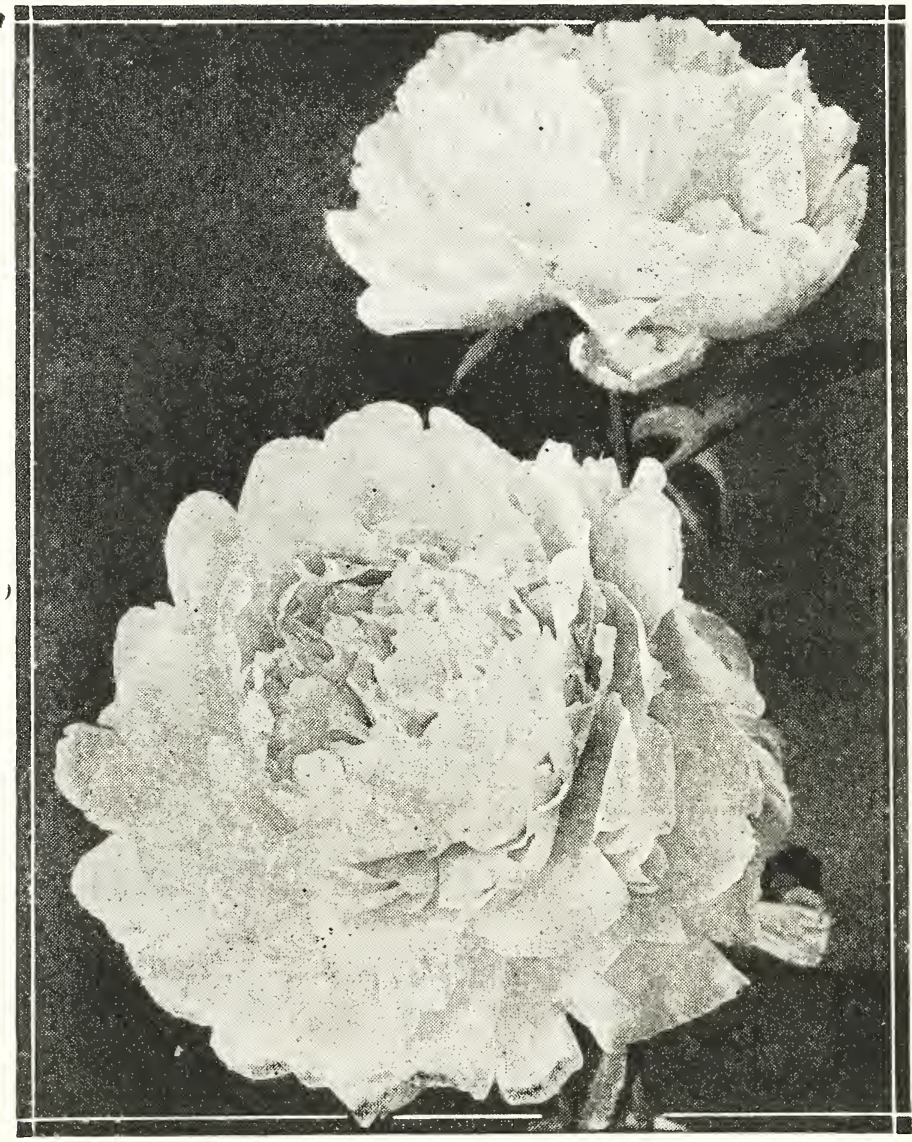
the best 


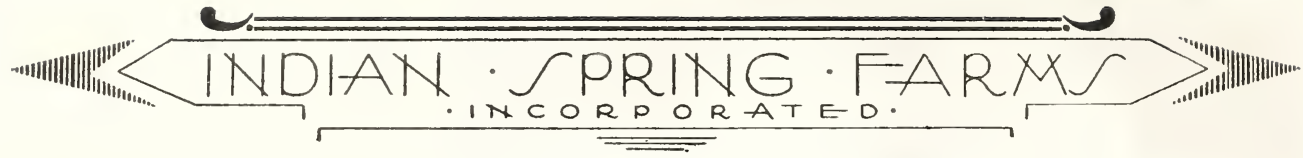

NELL SHAYLOR (Shaylor 1920. A medium-sized flower of semi-rose form that shows a few stamens and some partially transformed, gold-edged petaloids, arranged as a collar surrounding the center of broad petals. The general color effect is white, with a tint of light pink on the outer petals and a distinct golden glow reflected from the heart. The broad center band petals are distinctly marked red giving the flower a decided white, crimson and gold effect. On established plants, the petals have much substance. The plant is medium tall and vigorous with good upright stems. First descriptions classed this as a pink Peony but we find it more nearly a white than a pink flower.

$\$ 9.00$

NINA SECOR (Secor 1922) 9.0. A grand flower of purest white that has all the requisites of a first-class variety. The blooms are very large and are perfect rose form with broad, imbricated petals of much substance-very similar to the flowers of Enchanteresse. The season is a full week earlier than that fine variety and the flowers open more reliably under all weather conditions. The plant is tall, strong and vigorous.

$\$ 7.50$

NOKOMIS (Franklin). An attractive and striking flower of semi-rose form with the stamens mingled throughout the center of broad, imbricated petals. The color is light pink, with prominent markings of dark vermilion-red on the band petals. Fragrant.

$\$ 3.00$

NORFOLK (Richardson) 7.6. Very large flowers of compact, flat rose type. The color is light lilac-rose, very similar to Grandiflora. Fragrant. The growth is medium tall and upright, making this a desirable late-flowering variety.

$\$ 1.00$

NYMPHÆA (Thurlow, 1919) 8.8. This large, creamy-white flower is semirose type and has wide, silky petals, notched at the tips, and somewhat incurved. The yellow stamens in the center reflect a golden light through the whole flower. Fragrant. It is a tall, erect grower with good, long stems that support the blooms gracefully. A profuse midseason bloomer, and a desirable landscape white that may be depended on for a display of flowers each season.

$\$ 5.00$

OCTAVIE DEMAY (Calot 1867) 8.5. A delightful variety of dwarf growth that blooms early, just when the flowers are most appreciated. The blooms are large, crown type, with guards and center pale hydrangea-pink and the collar almost white. The guard petals reflex to the stem. A free bloomer on strong, upright stems.

$\$ 1.00$

We think so well of this Peony that we accord it a place in our "Backbone" Collection. See Page 84.

OLD SILVER TIP (Brand 1918) 7.4. The name itself aptly describes this flower. Its semi-rose type blooms of large size are produced in great profusion in midseason. The color is madder-red with a distinct silvery edge to the petals as the flower opens, and a marked silvery sheen over the whole petalage as it ages. It is a medium high, compact-growing plant, with good, strong stems. Even if you do not care particularly for the class of "grayheaded" Peonies, you cannot but admire Old Silver-tip-the shading is so artistically done.

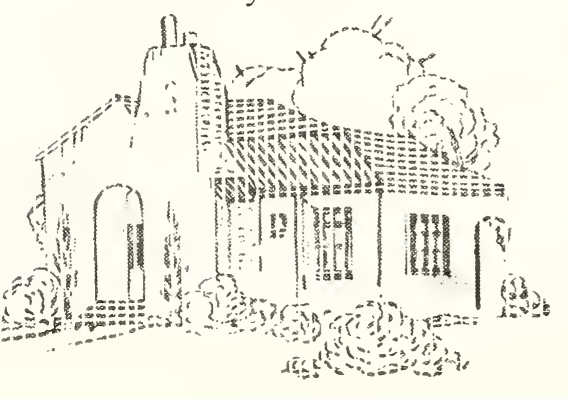

OPAL (Pleas 1908) 8.5. This really good Peony, originated by Mrs. Pleas, deserves consideration along with her Jubilee and Elwood Pleas. The flower is true rose type, without stamens or markings of any kind, and the petals are long, pointed, and 
OPAL (continued)

symmetrically imbricated, and just enough incurved to form a chalicelike cup of great beauty. On opening, it is a dainty baby-pink, changing to an opalescent French-white, and reveals the same delicate shadings at the heart that we find in the variety Mme. Emile Galle. The plant is medium tall, with good habits and medium strong stems. A free and reliable bloomer in late midseason. The Peony formerly listed as The Jewel is identical with Opal.

PASTEUR (Crousse 1896) 8.4. A very large flower of compact, flat rose type. The petalage is fine in texture, long and laciniated, making a lacy bloom of refinement and beauty. The color is delicate, soft pink, shading lighter at the center with a yellowish tint at the base of the petals. A strong, vigorous plant of good, upright habits. Late midseason. The variety might be described as a pink La Tendresse, or as a pink Jubilee with strong stems. In our opinion it is better than either of them. On account of diseased stock it has proved disappointing in many plantings, but with good healthy stock it is, indeed, a fine variety.

$\$ 2.00$

PAUL FISGHER (Richardson) 7.2. This old variety from the garden of John Richardson is worthy of a place in any extensive collection, and it is of particular interest to those who are making plantings of the Richardson Peonies. A large, globular flower of rose form, pale lilac-rose, fading to flesh-white. A tall, erect plant of medium habit that bears blooms of pleasing fragrance in midseason.

$\$ 1.50$

PERRETTE (Dessert 1921) 8.3. A loose, semi-double variety, white, slightly tinged flesh and straw-yellow, the central petals marked carmine. It is a free bloomer on good, strong, upright stems. Fragrant.

$\$ 4.00$

PETAGRA (Franklin). The very large, loose, light red flower has a circle of golden stamens surrounding the center petals, and the guard petals show light green stripes on the lower side. A tall, strong grower. Fragrant.

PETER PAN (Hollis 1907) 8.6. A large, flat, semi-rose type flower with rather loose petalage. Soft lilac-rose, changing to lilac-white as the flower ages; center petals marked crimson. A strong, vigorous plant of upright habits. Midseason.

PETITE RENEE (Dessert 1899) 6.9. A vigorous-growing variety that probably should be classed as anemone type, but produces a profusion of blooms in clusters that vary in form. The terminal bloom is usually semi-double, with prominent guards and narrower center petals of purplish carmine, loose and irregular in form. The lateral blooms are nearly always Japanese type, with the narrow, center filamental petals light purplish carmine, streaked white and tipped gold. A free, midseason bloomer. As a landscape plant this is an interesting variety. The light, airy blooms fairly float above the foliage, more like huge butterflies than Peony blooms. As cutflowers they do not last well.

PHILIPPE RIVOIRE (Rivoire 1911) 9.2. According to the decree of the American Peony Society, this is the best red Peony in the world. The flower is not large, as compared with some other red varieties, but is very symmetrical and "finished" in form, true rose type without any sign of stamens. It opens flat, with perfectly imbricated pointed petals. The color is bright, velvety crimson that holds without fading or burning 


\section{PHILIPPE RIVOIRE (continued)}

throughout the life of the flower, and it has a delightful rose fragrance that is rare in the red varieties. The plant is medium tall, healthy in growth, with strong slender stems. A fine Peony, equally good for landscape or garden plantings.

$\$ 12.50$

PHILOMELE (Calot 1861) 7.7. A very distinct flower of crown type, with a striking color scheme. It is medium size, with broad, prominent guards of bright violet-rose. The center is of deep golden yellow, ligulated, narrow petals that change to amber-cream, from the midst of which grows a small crown of bright rose petals edged dark crimson. The growth is medium tall and upright, with good strong stems. A splendid landscape plant and a popular cut-flower variety. Midseason.

$\$ 1.00$

PHOEBE CAREY (Brand 1907) 8.8. This late variety, that blooms with Marie Lemoine, is very beautiful and thoroughly reliable. It has a full, rose type flower, slightly cup-shaped, with large, broad petals of fine texture and good substance. It is a soft rose-pink, tinted lavender, shaded deeper at the center. Tall, strong growth, with an abundance of light green foliage. Delicately fragrant and lasts well when cut. The stock has always been scarce. One of the most desirable of all the Brand Peonies.

$\$ 5.00$

PHYLLIS KELWAY (Kelway 1908) 9.0. This large, loose, semi-double flower is strikingly beautiful and has a style about it that cannot be described. Outer petals are very large and broad and open in flat, cupped form, with a center of narrower petals loosely arranged, intermingled with bright golden stamens. Light pink, shading to flesh-white in the center. Strong, upright, and vigorous, with good stiff stems. A free bloomer in midseason. We like Phyllis Kelway and so will you.

$\$ 7.50$

PIERRE DESSERT (Dessert \& Mechin 1890) 7.6. An early dark red that gives a profusion of blooms just when they are most appreciated. The flowers are large, flat, semi-rose type, with wide, uniform petals throughout, and with the stamens arranged about the collar and scattered through the center. It is dark crimson-purple in color, with petals silvery tipped. When opened indoors, the blooms are very large and are uniform in color, making an unusually attractive show flower. The plant-growth is medium strong and healthy.

$\$ 1.00$

PIERRE DUGHARTRE (Crousse 1895) 8.2. This late-blooming variety is one of the most desirable Peonies. It has very large, compact, globular rose type flowers, with broad, rounded petals, uniform lilac-pink in color. The plant is medium tall, with strong, upright stems. A good landscape variety.

$\$ 2.00$

POMPONETTE (Dessert 1909) 7.3. A dwarf-growing variety that is especially adapted to landscape planting. The flowers are semi-rose type, large and full. Its color is a dark, velvety pink, shading to lively carmine-red at the base of the petals, and bordered silver. A very free bloomer in clusters. Midseason.

$\$ 1.00$

PONEMAH (Franklin). A very large, semi-rose type flower that opens flat. It is an even shade of soft pink, shading lighter at the edges of the petals. The outer petals are broad, and the center petals narrower and laciniated. A strong, sturdy grower and a free bloomer. Delightfully fragrant. 
PRESIDENT ROOSEVELT (Warnaar 1905) 7.7. A desirable red Peony that originated in England but was introduced from Holland. The flower is medium size, globular, semi-rose type, with compact petalage and with stamens irregularly scattered throughout the flower. The color is a distinct shade of brilliant dark red, different from any other red Peony we know. A medium tall, erect plant with slender but stiff stems. Midseason. Good either as a landscape plant or for cut-flowers.

$\$ 1.00$

PRESIDENT WILSON (Thurlow 1918) 9.3. This comparatively new Peony grows in favor with each succeeding season. It has a full rose type flower that opens soft rose-pink, changing to shell-pink. The guard petals are broad and sometimes striped crimson, and the center petals are short and somewhat laciniated, gradually increasing in length toward the outside, producing a cup-shaped flower of delicate beauty. Upright, graceful habit with strong stems. Late and very fragrant. One of the best landscape varieties, and the flowers hold well in the hottest sun.

$\$ 30.00$

PRIDE OF ESSEX (Thurlow 1916) 8.9. A fine variety that is in the same class with Lady Alexandra Duff and which it resembles both in color and form. The flower is large, loose, rose type with broad, rounded petals of perfect form. The color is delicate light pink, shading lighter as the flower develops. The buds are very large and delicately tinted pink, and open by expanding into immense pink spheres from which the outer petals unfurl first, leaving a globular center that is very charming. The plant is tall and vigorous and very free flowering. A fine variety for landscape use or garden planting. Midseason.

$\$ 5.00$

PRIMEVERE (Lemoine 1907) 8.6. A large, medium compact, flat, bomb type flower that is the nearest a true yellow of all the Chinensis varieties. The guards are creamy-white, splashed scarlet; the center a deep canaryyellow on opening, changing to sulphur-yellow. As cut-flowers, when kept away from the sun, the yellow color holds long. Very fragrant. The plant is a tall, strong grower, rather spreading in habit. Free midseason bloomer. Laura Dessert is very similar in color and form of bloom.

$\$ 2.50$

PRINGE OF DARKNESS (Brand 1907) 7.5. A large, loose, semi-rose type flower of rich, dark maroon color, shaded darker at the edges of the petals. It is a free-blooming variety that opens early and lasts long. The tall, strong plant is good for landscape effect. In color, it is almost as dark as Mons. Martin Cahuzac and very similar to Midnight, and like the latter variety, the flowers cannot stand too much sun without burning. $\quad \$ \mathbf{1 . 0 0}$

QUEEN (Kelway). An interesting flower of rose type that opens to a flat bloom of large size. The petals are long and irregular in shape and give a shaggy effect that is quite distinct. The outer petals are light pink, and the color shades deeper to bright carmine-pink at the center. A strong and vigorous plant of good habits that is very effective in landscape plantings. This is the "false Kelway's Queen" that has caused so much confusion as to the true variety of that name. It is easily distinguishable from Kelway's Queen, being an entirely different formed flower and having a very distinctive bud of peculiar, greenish, "pineapple" shape. Late midseason.

$\$ 1.00$

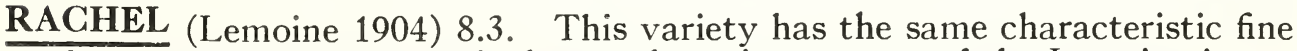
form and vigorous growth that we have in so many of the Lemoine introductions. The large, compact, rose type flower is globular in shape; and the color is soft flesh, or apple-blossom pink, such as we have in Sarah Bernhardt. A strong, medium-tall plant with upright stems. Late midseason

$\$ 4.00$ 


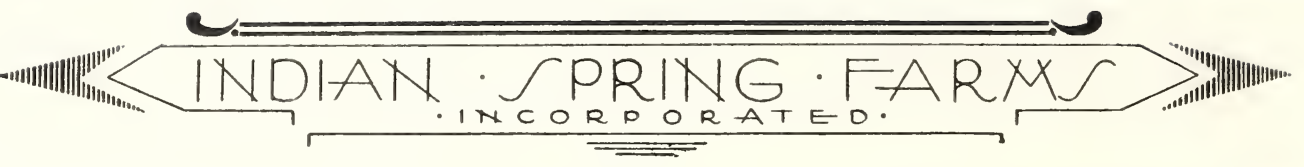

RACHEL (Terry 1900) 7.9. A good, free-blooming, reliable red that is fine for either landscape or cut-flower purposes, and can be had at a reasonable price. The flowers are medium size, semi-rose type, produced on a plant of good upright habit and pleasing foliage. In color, they are bright garnetred, shaded darker. Late midseason.

$\$ 1.00$

RAOUL DESSERT (Dessert 1910) 9.0. This is a very large, high, globular, rose type flower with a cupped center. The color is a distinct shade of mauve, shaded carmine-pink and silvery tipped; and the flowers are perfect in form and of pleasing fragrance. It is a medium tall grower, strong and upright, with good stout stems. In the bud, we find the same distinct old-rose coloring that characterizes the variety Helen Wolaver. This is one of Dessert's finest varieties, and we rate it very close to his famous Therese.

$\$ 7.00$

RAUENTHAL (Goos \& Koenemann 1913). A large flower of flat, semi-rose type. The petals of heavy substance are soft violet-rose with a delicate lilac tint, shading to silvery white at the tips. Like most of the German introductions, the plant is strong and vigorous, upright in habit with strong stems. A very desirable variety that blooms in late midseason.

$\$ 5.00$

RED BIRD (Franklin 1921) 8.6. This red Peony is distinct, both in form and color. The flower is medium large, flat, bomb type, with broad, prominent guards rose-red, surmounted by a loose dome of narrow, laciniated petals distinctly deeper red. Delicately fragrant. It is a medium tall, vigorous grower, with stems that carry the rather light blooms in good style. Midseason. No matter how many red Peonies you may have, there is still a place for Red Bird.

$\$ 2.50$

REINE HORTENSE. Syn. President Taft (Calot 1857) 8.7. The very large, flat, compact, semi-rose type flower is uniform hydrangea-pink with the color minutely flecked on a white ground, and the guards and center petals marked carmine. Slightly fragrant. The plant is tall, vigorous, and medium strong, with good stems. A free, midseason bloomer, and a good, reliable variety that is worthy of a place in any garden.

$\$ 1.50$

RENEE MARIE (Dessert 1920) 8.4. A very large flower of loose, semi-double form. On first opening, the bloom is tinted light pink, but quickly shades to white at the center. The guard petals are light pink and sometimes marked with red, and the center band petals are conspicuously streaked carmine. The plant is tall and vigorous, and the flowers are borne on long, erect stems. A free bloomer in midseason.

$\$ 5.00$

RICHARD CARVEL (Brand 1913) 8.8. A very large, bomb-type flower that is the first of all the reds to bloom. The prominent guard petals and the high, globular center are of a uniform bright crimson that holds well in the sun. Fragrance pleasing. It is a tall, strong, upright grower, and a free bloomer. The ideal habits of the plant and the early season of bloom make this a most desirable variety for commercial cut-flower purposes, and each year the demand exceeds the supply.

$\$ 3.00$

ROSA BONHEUR (Dessert 1905) 9.0. This is a very large, rose type flower with a delicate coloring and fine texture that has won for it a permanent place among the "Aristocrats." The broad, imbricated petals are slightly laciniated, giving a fringed effect that combines with the light violet-rose coloring in making a flower of refinement and beauty. The guard petals are flecked crimson. It is medium in height, erect and strong, with good stout stems. Late midseason. 


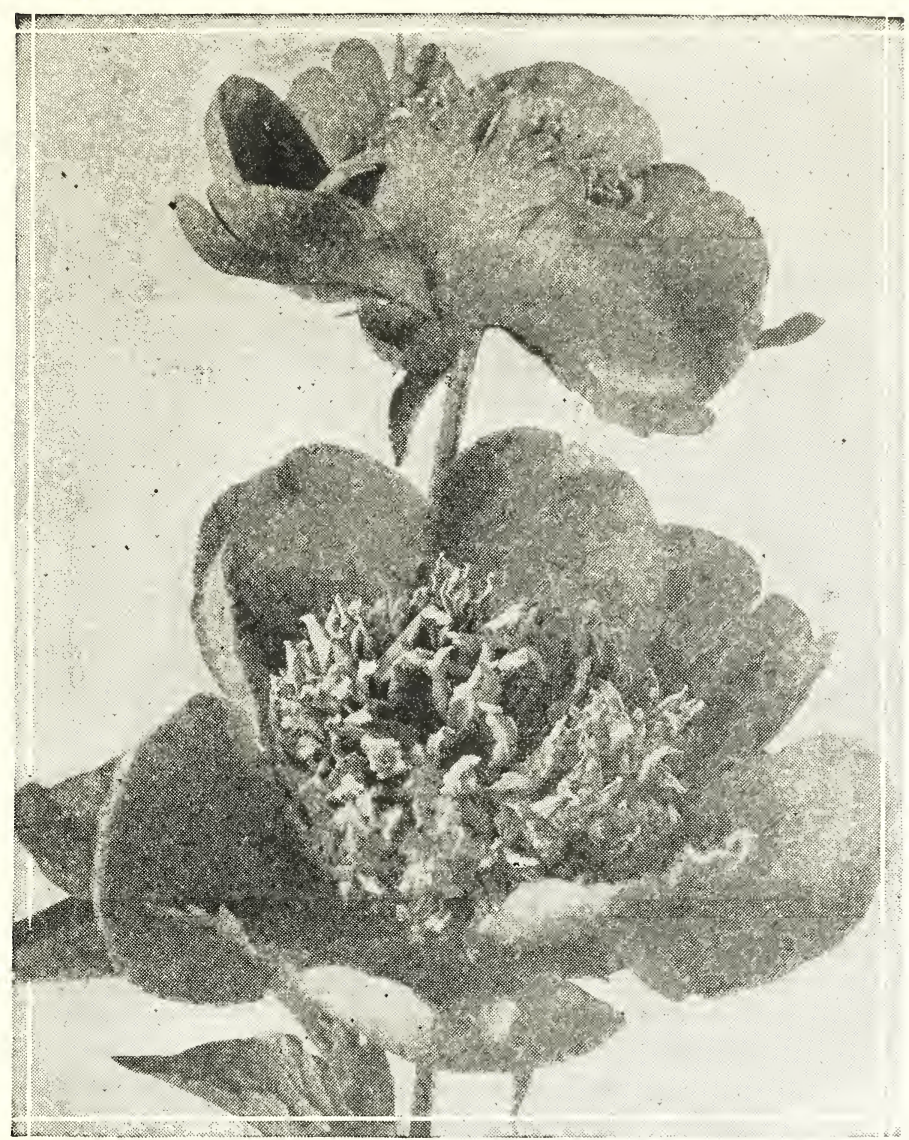

$\left[\begin{array}{c}\text { MIKADO } \\ \text { One of the finest Japanese } \\ \text { Peonies. An artistic flow- } \\ \text { er of crimson and gold }\end{array}\right]$
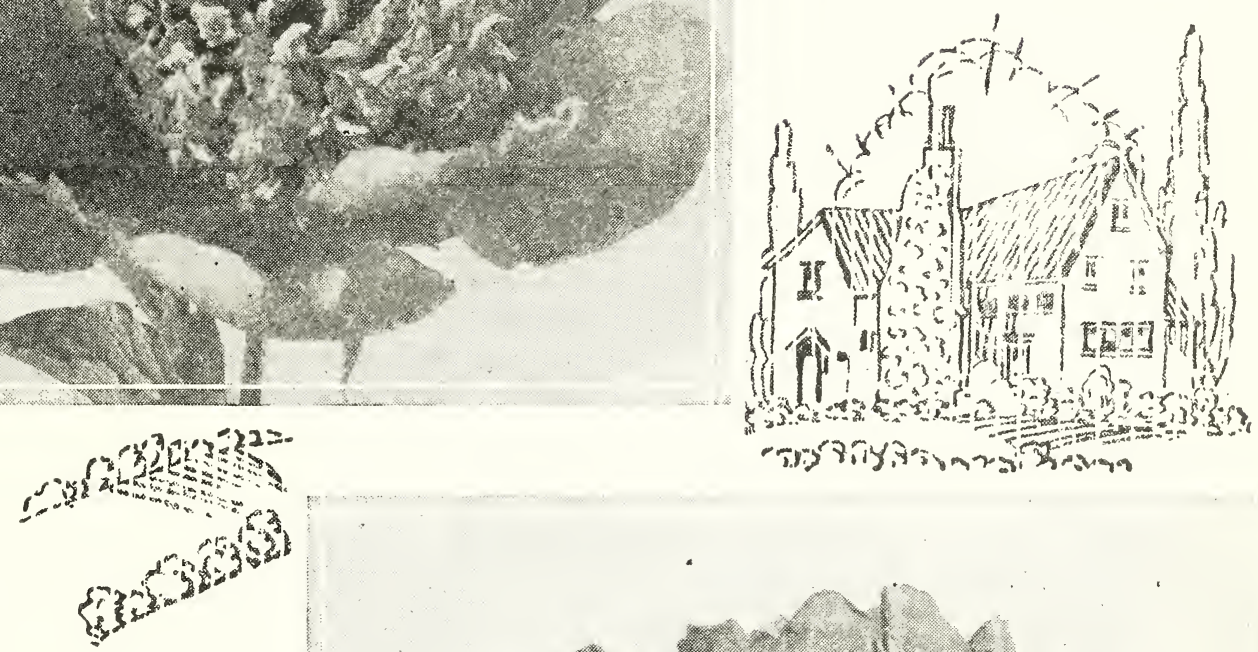

$\left[\begin{array}{c}\text { PHILLIP RIVOIRE } \\ \text { A rich, velvety crimson } \\ \text { that holds without fading }\end{array}\right]$

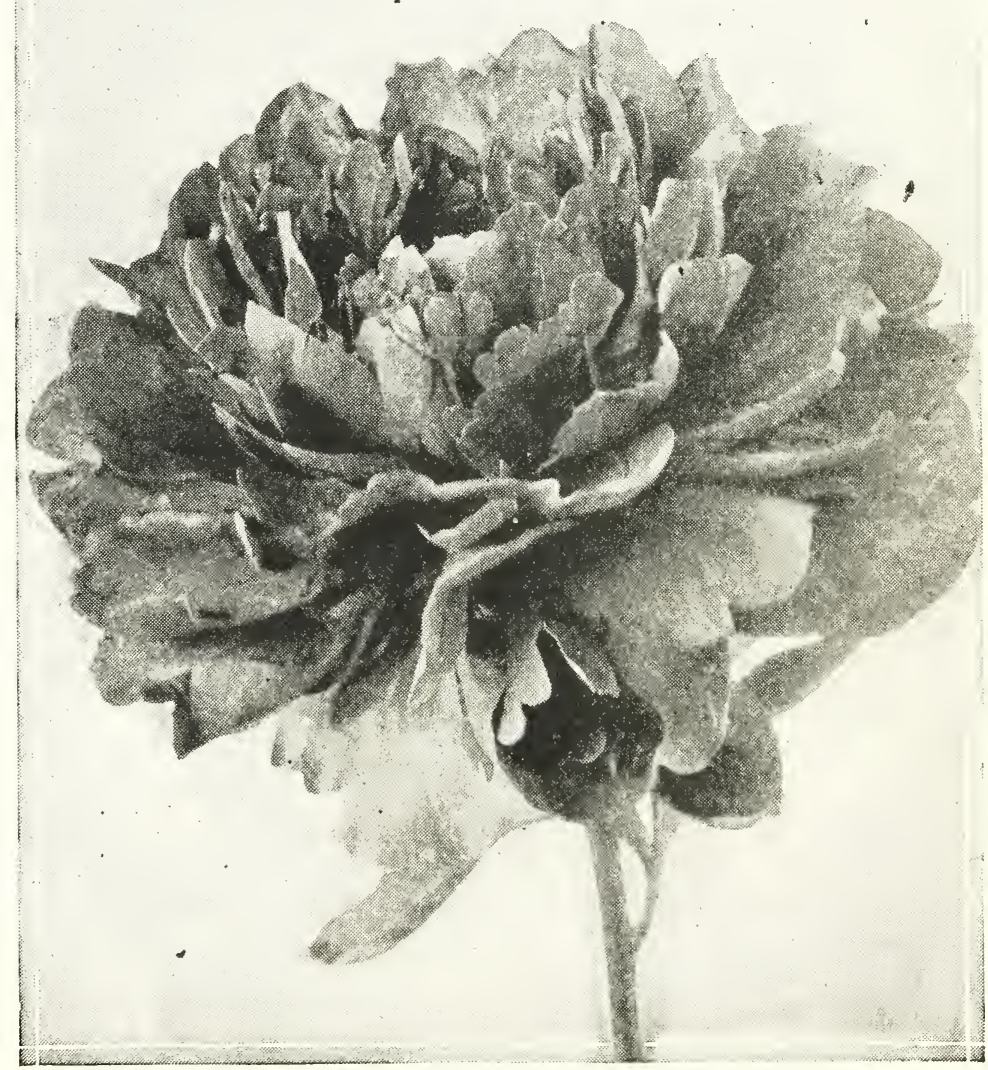




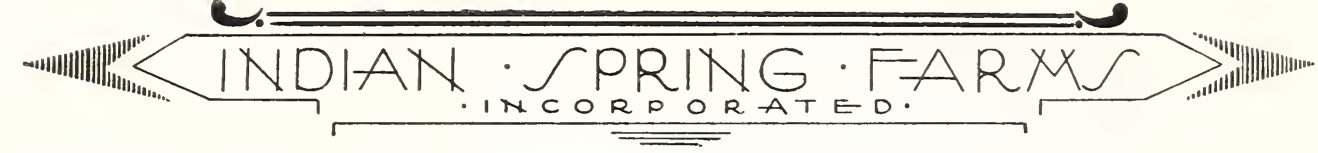

ROSE HERE (Brand 1907) 7.4. An attractive flower of medium size, loose semi-rose type, with two rows of broad guard petals and center of wide and narrow petals intermingled. A narrow white stripe runs through the center of many of the dark rose-red petals. A plant of good habits, blooming in late midseason.

$\$ 1.00$

ROSE SHAYLOR (Shaylor 1920) 9.1. This new Shaylor Peony well deserves a place in the "nine" class. The flower is very large, flat, rose type, with broad outer petals, and with the center nicely formed of loosely arranged petals of varying size. In color, it is delicate flesh-white, changing to almost pure white. Its dainty coloring and fine texture make a flower of exquisite beauty and great refinement. The plant is tall, vigorous, and strong, and the stout stems hold the flowers well up. A free, midseason bloomer with flowers of delicate fragrance. The stocks of this fine variety are very limited.

$\$ 20.00$

ROSETTE (Dessert 1918) 8.8. The large, loose, semi-rose type flower is distinct and attractive in form, with outer petals broad and rounded, surrounding a ring of stamens from which protrudes a center tuft of long petals. In color, it is silvery flesh, shading to salmon at the base of the petals, with center petals flecked crimson on the edges. It is an early bloomer on a plant of strong upright habit, and is a good landscape variety.

$\$ 5.00$

ROSY DAWN (Pleas 1909) 7.1. This large, loose, semi-double flower is irregular in form, with an attractive coloring of rosy pink, shading lighter. The plant is strong, upright in growth with free-blooming habit that makes it a desirable landscape plant. Midseason.

$\$ 1.00$

RUBRA SUPERBA (Richardson 1871) 7.2. A very late, dark red flower of informal rose type. The color is a deep rose-carmine that does not fade. Fragrant. The growth is medium strong and medium tall. This variety is slow to become established and does not usually bloom until the third or fourth year, and then is not always reliable. When it does come good, it is fine, and very desirable because of the late-blooming season.

$\$ 1.00$

RUTH BRAND (Brand 1907) 7.9. Where a good, free-blooming variety of pleasing color is wanted, this Peony is hard to beat. The flowers are large, compact, bomb type, uniform soft lavender-pink, shaded with deeper tones, and have a pleasing fragrance. It is a strong and vigorous grower with rather a spreading habit. Blooms freely in midseason.

$\$ 1.50$

SARAH BERNHARDT (Lemoine 1906) 9.0. This fine Peony stands out among all the rare and fine varieties as one of the universally satisfactory kinds. It has a refined flower, beautiful in color, and is a strong, vigorous grower, a free and reliable bloomer, and a rapid propagator. The flowers are very large, semi-rose type, with large, compact, imbricated petals of mauve-rose tipped silver. It is a late midseason bloomer; delightfully fragrant. At Duluth, where all Peonies seem to try to outdo each other in vigor, size, and floriferousness, Sarah Bernhardt is the largest and strongest of them all. At their fine Peony shows, competition for the best single bloom in the show usually becomes a contest as to who can bring in the best Sarah Bernhardt.

$\$ 2.00$

See "Backbone" Collection, page 84.

SARAH CARSTENSON (Terry 1901) 8.5. This fine variety is probably the best of the Terry introductions. The flowers are large, globular, rose type with wide, imbricated outer petals and a band of irregular narrower petals 


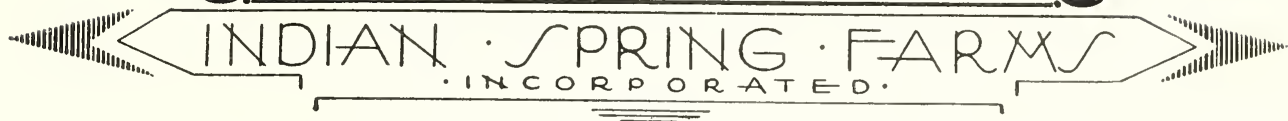

\section{SARAH GARSTENSON (continued)}

surrounding a ball center. The color is soft violet-rose, or deep shell-pink, that shades to flesh-white. The center-band petals are conspicuously marked oxblood-red. The plant growth is medium to dwarf with strong upright stems that amply support the heavy blooms. Midseason. Being a slow propagator the stocks are always limited.

$\$ 5.00$

SARAH K. THURLOW (Thurlow 1921) 9.1. A large rose-type flower with broad, rounded outer petals flesh-white, streaked crimson, and center petals broad and graduated toward the center, forming a cupped flower. The center petals are soft blush-pink, deeper than the guards, with an opalescent salmon shading. Fragrant. It is a medium tall, upright grower, with stems that support the flowers. Late midseason. In form and coloring, the flower resembles Tourangelle, and the variety may be aptly described as "a Tourangelle with better stems." This is considered by good Peony judges to be one of the best of the Thurlow introductions.

$\$ 15.00$

SECRETARY FEWKES (Shaylor 1916) 8.6. The very large, high, globular, rose type flowers, with broad, rounded petals of good substance, are deep creamy-white on the outer petals, shading lighter toward the center. A tall vigorous plant with good strong stems that support the blooms well. It flowers abundantly in midseason.

$\$ 5.00$

SERENE (Franklin 1921) 8.6. This full rose type flower is medium size, pure white in color, with an edging of carmine on the central petals. The plant is medium tall, with good sturdy stems and rich, dark green foliage. A midseason bloomer with pleasing fragrance, and a desirable landscape plant, equally good for cut-flowers.

$\$ 3.00$

SHAYLOR'S DREAM (Shaylor) 8.5. A very beautiful Peony that is not always appreciated because of its variable habits. On young plants, or when not thoroughly established, the flowers come almost true singles, but on mature plants the blooms are very large, semi-double, with a fine texture and are exquisitely beautiful. The outer petals are light fleshpink, broad and well differentiated; and the center petals are cream-white, long and irregularly fringed, and show a reflected golden tint from the conspicuous yellow stamens. A strong, vigorous plant of desirable habits. Midseason.

$\$ 6.00$

SILVIA SAUNDERS (Saunders 1921) 8.7. A charming little flower that is more like a wild prairie rose, both in form and coloring, than a Peony. The semi-double blooms open in flat, or slightly cupped, form with a double row of wide and rounded petals surrounding a center of short stamens and delicate light green carpels, tipped bright pink. The uniformly symmetrical flowers are produced in profusion on a plant of rather dwarf growth with strong, upright stems. Midseason. A fine and distinct landscape variety.

This Peony was originally introduced under the name "Silvia," but to $\$ \mathbf{\$ 1 2 . 0 0}$ avoid confusion with another variety of that name Professor Saunders has asked that it be known as Silvia Saunders.

SIMONNE CHEVALIER (Dessert 1902) 7.9.

This flower is very large in size and is medium compact crown type, with the guards and center pale lilac-rose and collar lighter. It is a tall, strong-growing plant, spreading in habit, that blooms early and freely. While this variety lacks the refinement in form and petalage of a real fine flower, its immense size and early blooming time makes it worth while for cutflowers.

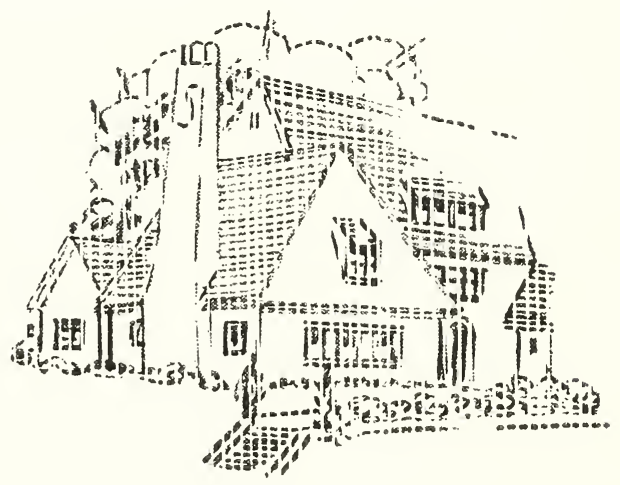




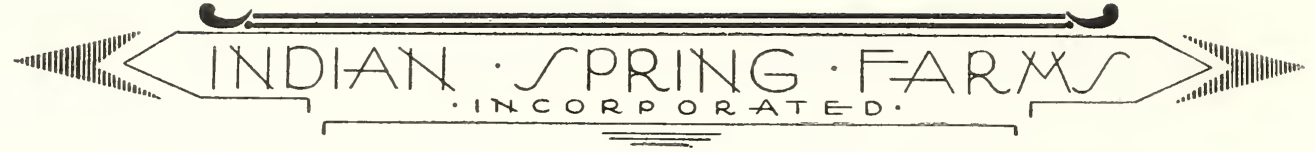

SISTER ANNIE (Brand 1907) 7.7. Its large, flat, semi-rose type flower is delicate shell-pink, heavily suffused with a deep rose. The edges of the petals are laciniated, giving a fringed effect to the flower that is very attractive. The plant is tall and strong and a free bloomer in midseason.

$\$ 1.00$

SOLANGE (Lemoine 1907) 9.7. It is hard to convey by words a proper conception of the beauty of this wonderful Peony which rivals Le Cygne for the distinction of being the world's finest variety. The form is perfect rose type, with broad, imbricated petals symmetrically placed, building up into a high, globular flower with a cupped center. In color, it is a deep creamywhite, shaded orange-salmon at the heart and suffused with a hue of reddish, or Havana, brown. The whole effect is similar to that known in the millinery trade as "tea shade." It is a medium tall, strong, vigorous grower, with good stems, blooming in the late season. The perfect form and distinct coloring make this one of the most sought-after varieties, and many of the most critical judges place it first on the list of the fine Peonies. $\$ 3.50$

SOLFATARE (Calot 1861) 7.6. This old variety was, until the introduction of Primevere, the nearest approach to a yellow peony. The flowers are medium in size and open up flat with a bomb center. In a fresh flower, the guards are clear milk white, and the center a pale sulphur yellow, but changes to sulphur white. The plant is vigorous and upright and flowers freely on every stem. Midseason. The variety has been widely distributed under the name Mont Blanc, but is very different from the true Mont Blanc originated by Lemoine. It, also, has been confused in commerce with Duc de Wellington and Miss Salway.

75 cts.

SOUVENIR DE FRANCOIS RUITTON (Riviere 1908) 7.8. Its mediumsized flower is a distinct, compact, rose type. The outer petals reflex back almost to the stem, and the compact center of narrow petals builds up in an irregular tufted form, making a high flower of much substance. In color, it is brilliant Tyrian-rose that does not fade or burn. The plant is tall, strong and erect, and the flowers are produced freely in clusters on very long stems. Late midseason.

$\$ 2.50$

SOUVENIR DE L'EXPOSITION UNIVERSELLE (Calot 1867) 7.6. The large flower is very flat rose form, with uniform, long, narrow petals, bright violet-rose with a silvery reflex, tipped silver. It is a free bloomer, in clusters; pleasingly fragrant. The plant is medium tall and vigorous of growth, with spreading habit and rather weak stems. Late midseason. The flat form and the bright pink at the base of the petals distinguish this flower from the other pinks. It has been sold by wholesale growers under the name Murphy's Pink.

$\$ 1.00$

SOUVENIR DE LOUIS BIGOT (Dessert 1913) 9.1. This is one of the most distinct and beautiful of all the pink varieties. The flowers are very large, convex, rose form, with fringed petals bright Bengal-rose, slightly tinged carmine at the base, changing to salmon-pink with a silvery reflex. It grows medium tall and upright, with medium-stiff stems. A free bloomer in midseason. There is a fiery brilliancy glowing from the heart of this flower that is wonderfully attractive. It is often described as being of the Walter Faxon coloring, but that is hardly true. Souvenir de Louis Bigot has deeper carmine shading at the heart, while Walter Faxon is bright salmon-pink. Both have a glow from the depth of the petals that is soft, yet brilliant. 
SPLENDIDA (Kelway) 8.3. This is a fine Peony and we cannot account for its comparatively low rating unless it is confused with the variety of the same name introduced by Guerin in 1850 , which is quite a different flower and much inferior. The true variety is a very large, globular flower of symmetrical, true rose form that opens in late midseason. The color is light violaceous-pink with a silvery sheen, uniform throughout, and the petals are broad, evenly rounded and perfectly imbricated, graduating to a cupped center. Delightfully fragrant. A free bloomer on a strong, upright plant of good habits. A fine cut-flower variety and equally good for landscape use.

$\$ 2.00$

STEPHANIE (Terry 1891) 8.0. A free-flowering variety that produces its very large, loose blooms in profusion on a tall, strong plant of good landscape habits. The flowers are pure white, with a band of conspicuous yellow stamens that reflect a golden tint throughout the center. Midseason.

$\$ 2.00$

STRASSBURG (Goos \& Koenemann 1911) 8.4. A very strong and vigorous variety that bears immense, flat, semi-rose type blooms on strong stems. The flower is bright violet-rose, shading lighter at the edges of the petals, which are long, evenly rounded and uniformly notched, and graduate toward the center. The stamens are concealed throughout the petals and show conspicuously in the center. A very distinct and desirable variety. Midseason.

$\$ 3.00$

SUZETTE (Dessert 1911) 8.2. The large, loose, semi-double flower has long, pointed petals intermingled with the golden stamens in a way that makes an attractive bloom of fine form. In color it is Bengal-rose, shaded deeper carmine-purple, with a silvery reflex. It is a free bloomer in midseason on a plant with fine habits and good strong stems. One of the best varieties for landscape planting.

$\$ 2.00$

THE GEM (Pleas 1909) 8.0. One of the tallest growing Peonies. The compact, rose-type flowers are brilliant dark crimson, produced on upright stems that stand over 4 feet high. Young plants are slow to become established and are not at their best until their third or fourth year. Midseason.

$\$ 2.00$

THERESE (Dessert 1904) 9.8. This is a wonderful pink that rates with Le Cygne and Solange as one of the three greatest Peonies. When one beholds for the first time a well-grown plant of Therese, with its wealth of immense flowers so imposing and yet so delicate in texture and coloring, it seems that perfection in flowers has surely been attained. The blooms are very large, full rose type that later develop a high cupped center, and the color is uniform, light violet-rose, shading to lilac-white at the center. The plant itself, as perfect in habit and form as the flower, is medium tall, strong, and vigorous, with sturdy, upright stems and heavy-set, rich green foliage. A free, midseason bloomer with delicate fragrance. For landscape or for show blooms it is equally fine.

$\$ 3.00$

THOMAS C. THURLOW (Thurlow 1919) 9.0. Another fine seedling that the Thurlows considered worthy of carrying the family name. The first rating places it in the "nine" class, and it will undoubtedly be rated higher when better known on established plants. Its flowers are large, semi-rose form, delicate salmon-flesh in color, changing to flesh-white. The guard petals are broad and reflexed; surrounding a heavy collar of wide petaloids with laciniated tips, some of which are edged with yellow. The center 
THOMAS G. THURLOW (continued)

petals are broad and quite long, giving a crown effect, with some of the tips marked carmine. The extreme center is made up of short yellow petaloids, surrounded by a ring of cup-shaped petals, edged yellow. The plant is vigorous and upright, with good strong stems. Midseason.

$\$ 20.00$

TOURANGELLE (Dessert 1910) 9.4. A large, rose type flower that opens in flat form and develops higher, with a cupped center. Its color is opalescent, pearly white, suffused with shades of delicate salmon and La France-rose. In texture and coloring, this is one of the most delicate and beautiful of all Peonies. The blooms come late and are very fragrant. The plant is medium tall and healthy, yet has an "effeminate" growth that is in keeping with the delicacy of the flowers it bears. The stems are slender and willowy and droop gracefully under the weight of the flower.

$\$ 2.50$

TRAGEDY (Hollis 1909) 8.0. A medium-sized flower of true bomb type that is of value because of its beautiful and brilliant color. The guard petals are broad and evenly rounded and surround a globular center of medium compact, narrow, pointed petals. The color is intense dark crimson that does not fade or burn. The plant is vigorous in growth with slightly spreading habit and should be supported for best effect. A free bloomer in late midseason.

$\$ 3.00$

TRIOMPHE DE L'EXPOSITION DE LILLE (Calot 1865) 7.8. This is a very large, compact, semi-rose type flower of the same flat-topped, pyramidal form that we have in Modele de Perfection. On opening, the color is pale hydrangea-pink with the petals minutely flecked with violetrose. As the flower ages, the guard petals change to nearly white. The plant is vigorous in growth, with spreading habit. A free and reliable bloomer in late midseason, and a favorite variety for cut-flowers. $\quad \mathbf{\$ 1 . 0 0}$

UMBELLATA ROSEA (Dessert 1895) 7.4. A medium-sized flower of informal rose form, with broad, cupped guard petals violet-rose, surrounding a center of amber-white narrower petals in which is found an occasional broad petal the same violet-rose color as the guards. The growth is strong and vigorous, and the flowers are borne freely on stiff, upright stems well above the foliage. This is the very first of all our hundreds of Chinensis Peonies to bloom, and the fragrance is delicate and agreeable. A desirable landscape plant, especially valuable because of its early blooming. The variety, unnamed, was found by Dessert in $M$. Mechin's collection and was introduced as Sarah Bernhardt until he learned its true name. It is distinctly different from Lemoine's Sarah Bernhardt.

$\$ 1.00$

VENUS (Kelway 1888) 8.3. This very beautiful flower is high crown type. The broad, well-differentiated guards are clear hydrangea-pink, with a collar of flesh-pink petals surrounding a compact center of broad petals arranged in tufted form, the same shade as the guards. Delightfully fragrant. A free midseason bloomer. The plant is very tall, strong, and upright, with a distinct, broad, light green foliage. This variety is confused in commerce and the rating has undoubtedly suffered on that account. The true Venus has also been freely sold under the name of Marie Stewart. Those who know the true variety consider it one of finest Peonies both for landscape use and for cut-flowers.

$\$ 1.50$

We regard this variety as worthy of a place in our "Backbone" Collection. See page 84. 


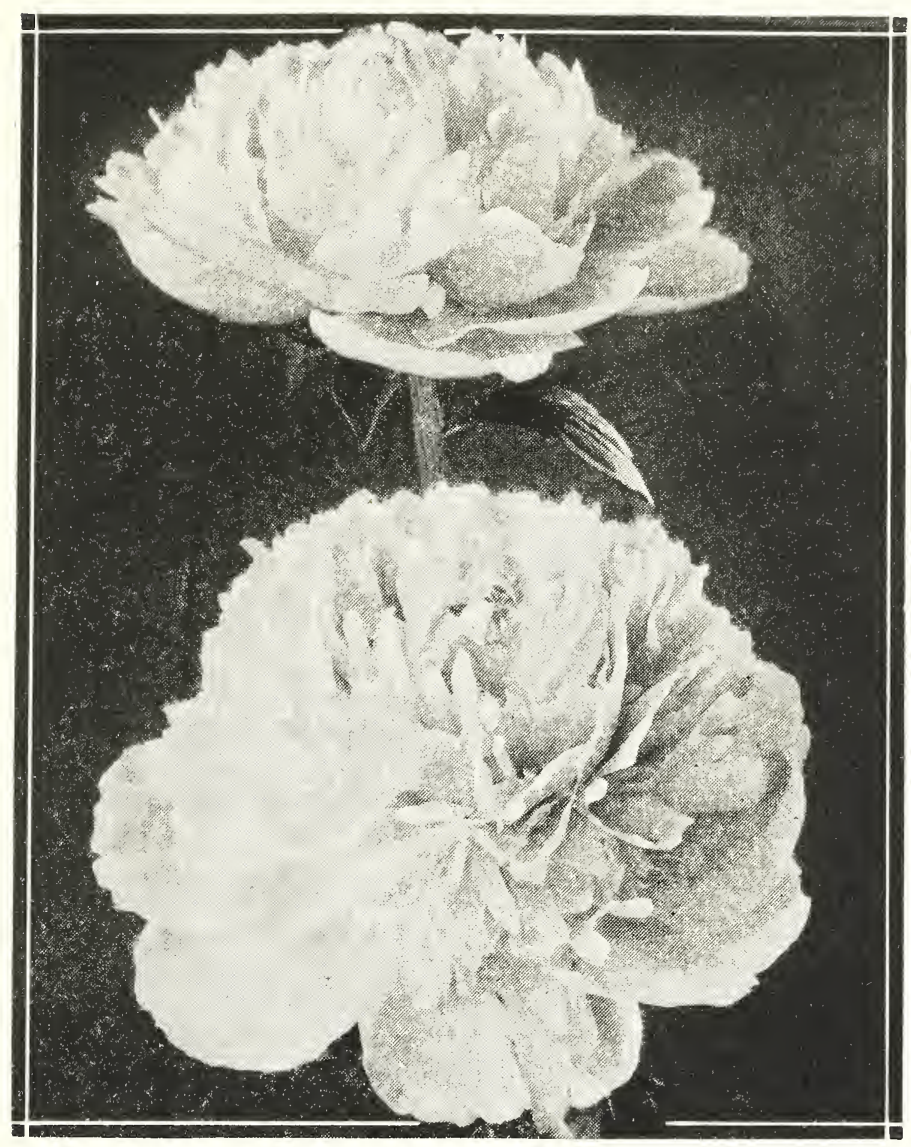

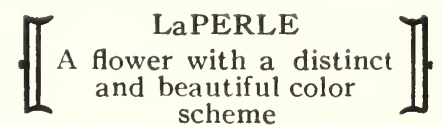
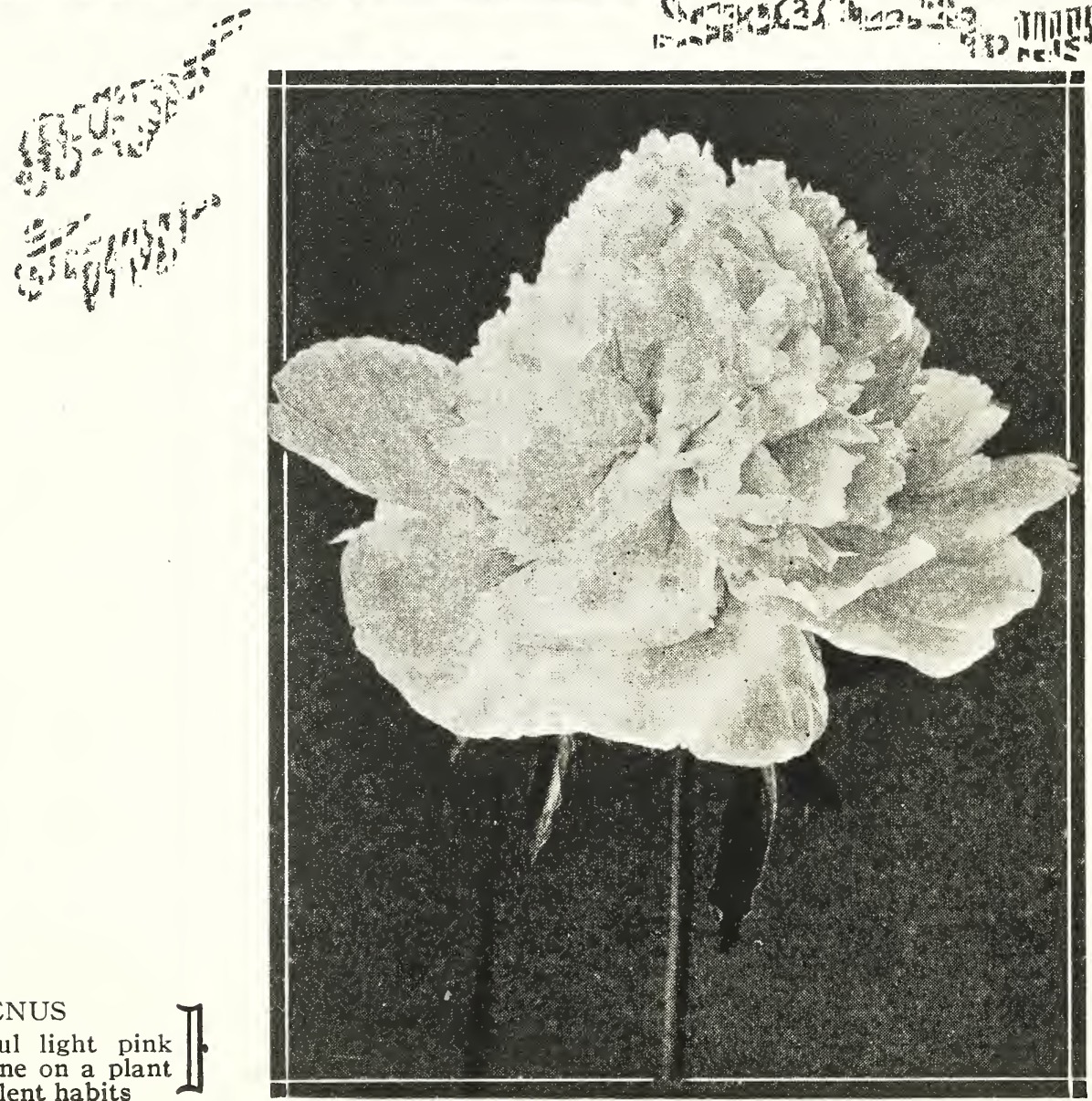


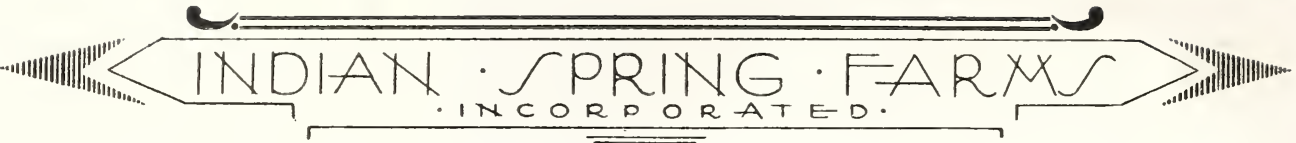

VICTOIRE DE LA MARNE (Dessert 1905) 8.2. This stunning flower is one of the very largest Peonies. The blooms are loose rose type, globular in form, made up of broad petals of velvety amaranth-red with silvery reflex. It is a very bright flower that commands attention in the garden or on the show table. The plant is medium tall, strong, and vigorous, and a free bloomer. Midseason.

$\$ 2.50$

VICTORY CHATEAU THIERRY (A. M. Brand 1925). A very large flower of perfect rose form. The wide, rounded petals are arranged in a symmetrically imbricated form that is very finished. Bright, clear pink in color and pleasingly fragrant. The plant is rather dwarf in height with strong, erect stems. Midseason.

$\$ 50.00$

WAH-WAH-TAY-SEE (Franklin). This new variety with its curious Indian name is very attractive. The flowers are very large, semi-double with golden stamens showing prominently in the center. The color is uniform deep mauve-pink, shading to silvery pink at the edge of the petals. A strong plant, desirable for landscape use.

$\$ 3.00$

WALTER FAXON (Richard 1904) 9.3. When all the finest pink Peonies are set up together on the show table, Walter Faxon seems at its best, and stands out like a light in the dark as the one real pink. It is a mediumsized flower of semi-rose type, globular in form, with a cupped center. The petals are of delicate texture that fags in the sun, yet comes back fresh and fine in the cool of the evening, or when handled indoors. In color, it is a soft coral-pink, shaded lighter at the ends of the petals and deeper rosepink at the base. The concealed golden stamens add a salmon reflection through the pink of the petals. It is medium tall and vigorous. Midseason. As a show flower, it is one of the most distinct Peonies and should possibly rate at the top of all pinks. As a garden variety, it lacks substance and must stand back for Therese and President Wilson.

$\$ 3.00$

W. F. GHRISTMAN (Franklin 1921) 8.8. This full rose-type flower is of large size and delicate flesh-pink color, changing to flesh-white. The guard petals are broad and of splendid substance, and the center petals narrower and laciniated, forming a cupped center. A strong, upright grower and a free and reliable bloomer. Midseason.

$\$ 6.00$

WILLIAM F. TURNER (Shaylor 1916) 8.4. The only double red introduced by Mr. Shaylor. It has a large flower of very dark crimson, with a velvety sheen, and blooms in early midseason, lasting without fading until the last petal has fallen. The form is loose, semi-double, with the broad petals intermingled with the golden stamens. It is a strong, vigorous grower with rich dark green foliage. A fine landscape variety.

$\$ 3.00$

WILLIAM MESMAN (Kernberger 1914). A beautiful white flower on the order of Festiva Maxima that, when well grown, is even a larger bloom than that grand variety. The broad petals of good substance are white throughout with an occasional touch of red on the center band petals. A free bloomer in midseason.

$\$ 2.00$

WILTON LOCKWOOD (Shaylor 1915) 8.8. A fine variety that commands attention by its wonderful plant-growth as well as by its attractive flowers. It is very tall, often reaching a height of 5 feet, with strong, upright stems that hold the blooms perfectly. The flowers are large, loose, flat, semidouble with broad, rounded petals which wholly conceal the stamens. The color is soft rose-pink with conspicuous crimson markings on the center-band petals. Midseason.

$\$ 10.00$ 


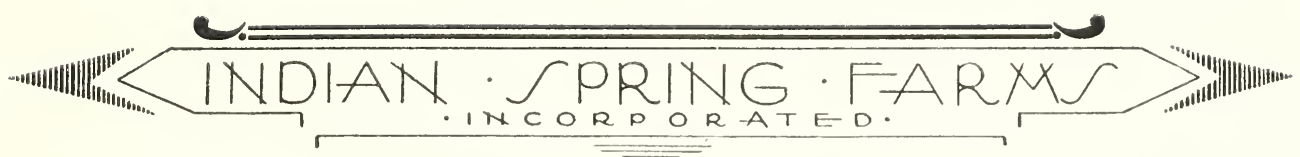

WINNIFRED DOMME (Brand 1913) 8.3. This is another of Mr. Brand's reds that has climbed up five points on the rating scale as it has become better known. Of all the reds, this is the brightest and clearest. The plant is rather dwarf in height and produces its flowers on very strong, upright stems. The blooms are large bomb type, with broad reflexed guards and a compact, globular center. It blooms in early midseason. For a brilliant landscape plant of low stature, Winnifred Domme is best of all.

$\$ 2.00$

\section{Single Peonies}

The increasing interest in Peonies for landscape plantings has created a demand for the better single varieties. The very large flowers, borne singly or in clusters, on shapely, upright plants, come in a range of pleasing colors and give an effect, when used either in mass or as specimen plants, that cannot be equalled by the finest of the double varieties. They hold well both in wind and sun, and their habit of closing in the cool of the evening, like immense rosebuds, is most pleasing.

The following list includes most of the best singles now offered in commerce.

ALBIFLORA. See The Bride.

BLACK PRINGE (Thurlow 1915) 8.5. A finely formed flower, very dark garnet-red in color, of a flat, velvety quality instead of the usual glossy appearance. The center is a clear mass of golden stamens that do not turn black. A strong, upright plant of fine landscape habits. One of the best of the single red varieties.

$\$ 3.00$

CELESTE BROCHET (Brochet.) This desirable single Peony is little known in this country and is seldom seen except in the gardens of collectors. The large, handsome flowers have long and rounded petals of milk-white, minutely flecked with lilac, giving a total effect of soft flesh-pink. The growth is medium tall, vigorous and free flowering. Early midseason. Similar in coloring to Marguerite Dessert and Kelway's Wild Rose, it appeals to those who admire the unusual.

$\$ 2.50$

CLAIRETTE (Dessert 1905) 8.1. In bud, this good variety appears lightly tinted pink but opens to a clear white of large and perfect form, with a pleasing center tuft of golden stamens. The flowers are borne in clusters on strong stems. A first-class variety.

$\$ 2.00$

DARKNESS (Brand 1913) 8.2. This fine single has all the qualities necessary to make the variety desirable for either landscape use or garden planting The flowers are large, well formed, have good substance, and are produced freely on a plant of good habit and appearance. The color is very dark maroon with darker markings on the lower half of the petals, which surround a bold cluster of golden stamens. Very early.

$\$ 2.00$

\section{DEPARTING SUN (Wilkus). A very large} flower of fine form and enduring substance. The petals are uniform deep cherry red that hold their color well and show in charming contrast with the bright lgolden stamens of the center. The plant is upright and graceful. A midseason variety that is very decorative in landscape use. Not to be confused with the Japanese variety of the same name.

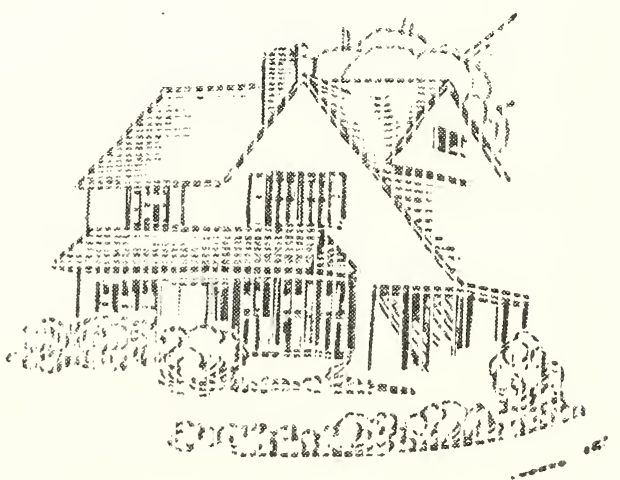




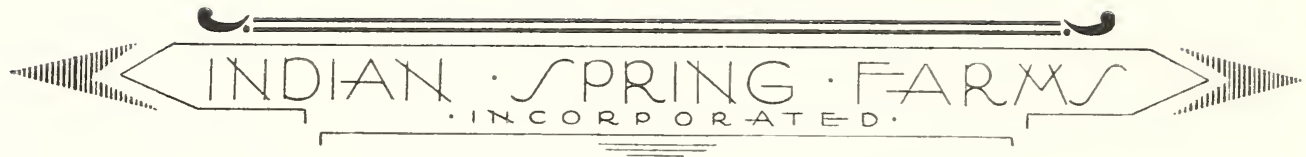

DOROTHY ALLISON (Shaylor). Mr. Shaylor's own description briefly describes this variety, "very fresh pink with petals splashed with carmine." The plant is attractive and makes a grand display when in full flower. \$2.50

From all his seedlings, Mr. Shaylor selected eight singles that he considered distinct and worthy of a place in commerce, - three whites, three pinks and two reds. Of the eight, Le Jour has met with greatest favor and now is honored as the highest rated white single. Dorothy Allison, Shirley Walker, L'Innocence and Deborah Sayles have never received ratings, but all are good Peonies, well worth growing.

EMILY (Kelway) 7.4. A very early single of medium size having a double row of petals. Color bright violet-rose, shading lighter at the edges. Medium tall, straight stems. Its chief value is for use as a very early landscape plant.

$\$ 1.00$

FLAG OF TRUCE (Kelway 1900) 6.8. One of the many singles introduced by Kelway that is so nearly like many other white singles that its outstanding feature is its attractive name. The flowers are large, lilac-white, and produced in profusion on a medium dwarf plant of strong, erect growth. An inexpensive variety that will furnish a quantity of flowers.

$\$ 1.00$

HELEN (Thurlow 1922). This new pink variety from Thurlow's is still so rare that it will command a high price for some years to come. The flower has a double row of broad, deep shell-pink guard petals of great substance that for several days hold a half-open cupped form, surrounding a pleasing center of golden stamens and carpels of clear light green tipped pink. The plant is very tall, strong and upright, and is usually the first of the Chinensis Peonies to bloom.

$\$ 10.00$

LE JOUR (Shaylor 1915) 8.6. This highest-rated white single gains in popularity each year. The flower is very large, with perfectly formed, long, rounded petals of remarkable substance, surrounding a center of golden stamens in the midst of which is placed the carpels of green, tipped bright carmine. A strong, upright plant of good form and habit. Midseason bloomer.

$\$ 3.50$

LE NOIR (Shaylor 1915) 7.4. Medium-sized flowers with evenly rounded petals of good form. The color is very dark crimson with a glossy finish. A good landscape plant of medium height.

$\$ 2.00$

L'ETINCELANTE (Dessert 1905) 8.4. The flowers are very large and cup shaped, with broad petals of bright pink distinctly margined with silver; center stamens bright yellow. A tall, fine plant that commands attention in any planting.

$\$ 2.50$

L'INNOCENCE (Shaylor). A beautiful single variety with satiny, white petals of good substance. The center tuft of light yellow stamens surround the stigmas of light amber, producing a color effect of distinctive purity. \$3.00

In our observation of both the single and Japanese type Peonies, we find that the shape and color of the stigmas play an important part in the attractiveness of the flowers. The coloring of the stigmas varies much from light greenish-white to yellowish and reddish-green. In some varieties, the stigmas darken as the flowers age, and produce a very unattractive appearance. In others, the coloring is delicate and clear so that they are inconspicuous, or make a pleasing addition to the color scheme of the bloom. The bright carmine tips of the stigmas in Le Jour are conspicuous and attractive in their contrast; the soft yellowish tint of the stigmas in

L'Innocence adds to the daintiness of the flower

LUCIENNE (Dessert 1908) 7.7. A tall, vigorous variety, bearing large flowers of white, flushed purplish-carmine; center of bright yellow stamens. The pleasing habits of the plant make this a most desirable landscape variety. 


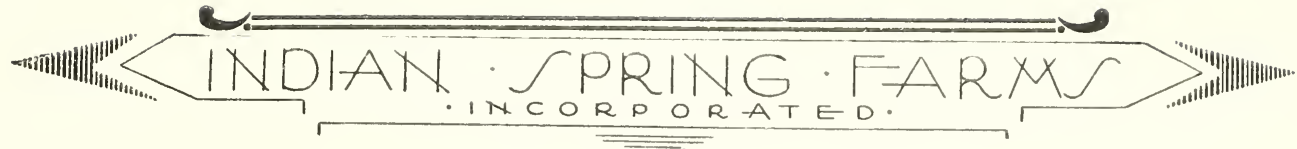

MADELEINE GAUTHIER (Dessert 1908) 8.5. Words cannot convey the distinctive beauty of some of the different single Peonies. To say that this flower is perfect in form, with petals of silvery flesh-pink surrounding a nice clean center of golden stamens, is a cold description to convey the delicate beauty of the bloom. The exquisite flowers are freely borne on a plant of most desirable form and habit.

$\$ 3.00$

MARGUERITE DESSERT (Dessert 1913) 8.5. This is another variety that has to be seen before its delicate beauty can be appreciated. The petals are white, evenly and entirely powdered with minute carmine dots, producing an effect of soft pink; center of bright yellow stamens. An established plant of this variety makes a truly wonderful display of blooms.

$\$ 4.00$

MARJORIE ALLISON (Shaylor) 8.3. An attractive white single with long petals, slightly cupped, that have a beautiful satiny sheen. A free bloomer on a plant of medium growth. Midseason.

$\$ 3.00$

MELLEN KNIGHT (Brand 1920). A flower of medium size and wonderful color. The petals are of good substance, rich dark red, surrounding a center of golden stamens and reddish-green carpels. Its plant is very tall and erect, and the flowers are held upright at all times on stiff, reddish stems. A very attractive landscape variety.

$\$ 3.00$

MINNEHAHA (Pleas). This bright single variety from the garden of Mrs. Pleas has never received the recognition in the Peony World that it deserves. Those who know the variety will bear us out in the statement that as a landscape Peony it adds a splash of color that is distinct and pleasing. The large flowers that are borne in great profusion are a uniform shade of bright cherry-red that contrasts with the center tufts of clear gold stamens, producing a color effect that is really gorgeous. If you like single Peonies, plant Minnehaha.

$\$ 2.00$

MISCHIEF (Auten 1925). This charming single peony has attracted much favorable comment at recent exhibits on account of its perfect form and pleasing color. It is a uniform soft pink that blooms late after most of the single flowers have passed. The blooms last well, and are borne freely on a plant of excellent habits.

$\$ 5.00$

NELLIE (Kelway) 8.6. A very large flower of uniform shell-pink. The petals are long and rounded, symmetrically arranged around the center of yellow stamens. It is a medium-tall grower, with strong, upright stems that support the flowers well. A fine plant for landscape use.

$\$ 3.00$

PRIDE OF LANGPORT (Kelway 1909) 8.9. This fine variety carries the highest rating of all the pink singles. The guard petals are large and well rounded, surrounding a center of long yellow stamens; carpels light green, tipped pink. It is a tall and vigorous grower, with small, wiry stems that carry the flowers in clusters. The soft, pleasing pink color and the delightful habit of growth make this a very desirable variety.

$\$ 5.00$

PRINCESS OF WALES (Barr). A vigorous-growing and free-flowering variety that produces large single flowers of soft pink, shading lighter at the edges of the petals. The wide-open flowers resemble immense wild roses in their form and color. An old variety that is still scarce. 


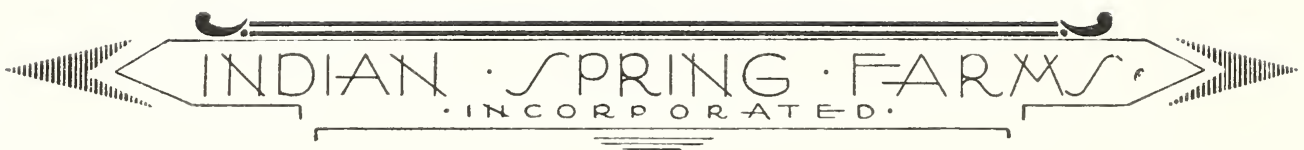

ROSY DAWN (Barr) 8.5. A very desirable single flower that is tinted soft pink as the bud opens, changing to pure white as it develops. A strong, vigorous plant with branching stems that bear a prof usion of blooms which show in rich contrast above the heavy dark green foliage. Midseason. \$1.50

SCHWINDT (Goos \& Koenemann). A tall, vigorous plant with heavy foliage and strong stems that bear immense saucer-shaped blooms of light violet-rose, shading lighter at the borders. An early variety that is desirable more for its massive garden effect than for its individual flowers.

$\$ 3.00$

SHIRLEY WALKER (Shaylor). A beautiful light pink single of exquisite coloring and delicate texture. The long, oval petals have a peculiar crepelike appearance with a sheen like satin. To appreciate all the beauty of this variety the flowers should be cut in bud and opened indoors away from the sun.

$\$ 3.00$

SILVER CUP (Kelway). This large pure white single resembles Albiflora in its form and habit of growth. The flowers are symmetrically formed and have the habit, like most of the singles, of drawing up in the cool of the evening to a half-open, or cupped, form. The plant is medium strong and very free flowering. Early midseason.

$\$ 3.00$

THE MOOR (Barr) 8.0. A showy flower of medium size. The petals are dark purple-garnet, almost as dark as Mons. Martin Cahuzac, surrounding a pleasing center of yellow stamens. Plant is medium tall, vigorous, and very upright. An early and prolific bloomer.

$\$ 2.00$

THE QUEEN (Kelway 1902) 8.3. This white single is said to be the parent of many of the Pleas introductions. In both flower and plant it is similar to The Bride. The large, smooth petals open with a delicate flush of pink and change to clear white throughout; the center stamens are clear, bright yellow.

$\$ 1.50$

VELOUTINE (Dessert 1908) 7.3. This tall, vigorous variety bears its large flowers in cupped form, like immense tulips, on strong, upright stems. The color is bright Tyrian-rose with velvety reflex. A charming single that makes a beautiful specimen plant.

$\$ 2.00$

VERA (Gumm). This new and rare variety will be rated very high when it becomes sufficiently well known to acquire a rating. Its immense flowers have large, well-rounded guard petals of dark crimson, sometimes streaked white on the reverse side and in the center is a thick ball of bright golden stamens that do not turn dark with age. The blooms last long and hold their color until the last petal has fallen. It is medium tall, strong and upright, with a pleasing dark green foliage that makes it a plant of great beauty.

$\$ 12.00$

Nothing reads more prosaic than an attempted verbal description of a single Peony. One who has seen a planting of several thousand seedling Peonies, a majority of which are singles, each one different from all the others, and every one beautiful with its "single row of well-formed petals surrounding a center cushion of bright gold stamens" can best realize the futility of trying to express the difference between single Peonies in mere words. There is character, charm, or something in the flowers that we have no adjectives to describe and which makes varieties distinctly different even though their descriptions read alike. To fully appreciate just what makes such varieties as Vera, Le Jour, Harriet Olney, Helen and Pride of Langport outstanding and superior, one must grow them in his own garden, or see mature plants in all their glory.

WHITLEYI MAJOR. The flowers of this variety are large, evenly formed, of purest white, similar in appearance to Albiflora. The plant is vigorous and of slightly spreading habit and produces blooms in great profusion. 


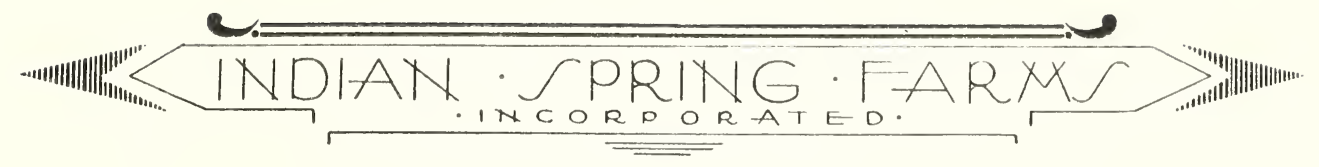

\section{Japanese Type Peonies}

The Japanese type Peonies comprise a class of flowers that are as yet little known as compared with the usual semi-double or full-double varieties. The name "Japanese" is somewhat misleading inasmuch as they are not necessarily of Japanese origin. The name merely refers to the type of the bloom that is next in the process of doubling above the true single form in which the pollenbearing stamens are more or less transformed into staminodes or narrow petaloids, showing traces of the yellow of the stamens. This type of Peony has long been admired by the Japanese people and hence their name is used to designate that distinct type.

Much confusion exists in the nomenclature of the Japanese Peonies, particularly those whose origin is traceable to Japan. It seemingly has been impossible to obtain these Peonies from the Japanese growers true to name. Different foreign growers have received assorted shipments from Japan under numbers, and after accumulating stocks of the desirable kinds, have sent them out under names of their own choosing. We now find identical varieties from France, England and Holland under sometimes as many as three different names. This matter is now being taken up by the American Peony Society, in co-operation with the leading foreign growers, and a test planting is to be established under the auspices of the University of Illinois at Champaign, Ill., through which it is hoped to clear up the identity of these varieties as was done for the double Peonies at Cornell some years ago.

We have given careful attention to our plantings of the Japanese Peonies. The varieties here listed are all distinct and different, and we believe they are true to name as given. While increasing demand that exceeds each season the available supply will maintain the comparatively high prices on many of the varieties for several years to come, we are able to offer the following comprehensive list of the better kinds in limited quantities for shipment in the fall of 1927.

AKALU (Japan) 8.1. Medium-sized flowers of bright rose-red or carminered petals, surrounding a center tuft of half transformed staminodes of gold, faced rose-red; carpels light green tipped cream. The plant is medium tall, upright in habit and carries its blooms gracefully on strong stems. Midseason.

$\$ 3.00$

AKASHIGATA (Japan). A single row of broad, rounded, evenly formed petals of bright carmine-rose surrounds a center full of partially transformed staminodes edged with chamois and faced deep pink. The plant is medium tall and upright in growth, with heavy, dark green foliage that is very attractive. A fine landscape plant.

$\$ 3.00$

ALMA (Shaylor 1916) 8.5. A single row of more or less irregularly formed petals delicate rose-pink surround a heavy center of partially transformed petaloids of bright yellow, edged and tipped gold. The center carpels are light green, tipped pink. An occasional "feather" petal appears among the yellow petaloids on well-established plants. Medium tall and graceful.

$\$ 2.00$

ALTAR CANDLES (Pleas 1908) 8.0. The evenly formed row of flesh-pink guard petals surround a center of fully transformed narrow filamental petals that are uniform cream-white when the flower opens. As the bloom ages, the tips of the center petals become carmine-tipped, like minute wax can dles, making a flower of distinct and attractive appearance. 'The carpels are reddish-green, tipped red. In growth, it is medium tall and upright. 


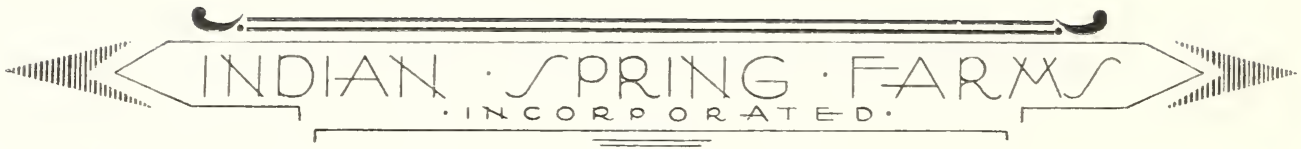

AMA-NO-SODE (Japan) 9.2. One of the best of the Japanese Peonies. The single row of petals are long, evenly rounded, and uniformly cupped, forming a perfect saucer of bright rose-pink, holding a globular center of halftransformed staminodes, yellow at the base, with the flattened upper half chamois-yellow, edged gold and faced with pink of the same color as the petals. Carpels light green. tipped pink. The plant is tall and vigorous with heavy, rich green foliage.

$\$ 10.00$

AUREOLIN (Shaylor) 8.9. This beautiful variety comes very near being the long-sought-for yellow peony. The single row of guard petals are broad and evenly rounded and surround a center of fully transformed petaloids of deep sulphur-yellow that hold their yellow color well. Either much of the stock of the variety has been weakened from over-propagation or it is not naturally vigorous in its habits for we have often seen it not doing well. When well grown, it is very beautiful-more desirable than Alma.

$\$ 3.50$

CATHEDRAL. Syn. Hana-no-Sato (Japan) 8.1. The guard petals are deep violet-rose, surrounding a center of fully transformed, pointed, filamentous petals of creamy-white, unevenly suffused violet-rose. A distinct color effect that is very effective. The plant is medium tall, vigorous, and has good, upright stems. Midseason.

$\$ 2.50$

DAWN (Wallace). A charming flower of fine form and firm texture. The single row of guard petals is soft pink, and the heavy center is made up of broad, irregular, partially transformed staminodes of clear sulphur-yellow, edged at the ends, with the gold of the anthers. The carpels are yellowishgreen, tipped bright red. Established plants produce very large flowers that are very beautiful and that last well as cut-flowers.

$\$ 3.00$

DISTINCTION (Dessert 1895). A large flower with broad petals of clear violet-red, surrounding a center of fully transformed, narrow filamental petals of the same color as the outer petals, irregularly striated with golden lines.

$\$ 2.00$

EXQUISITE (Japan 1912) 8.9. This truly "exquisite" variety has very large flowers with cupped guard petals of purest white enclosing a center of short filamentous petals that are pale sulphur-yellow as the flower opens, changing to white. The exposed carpels are light green, tipped white. The plant is slow but strong in growth with long, upright stems.

$\$ 5.00$

FLAMBOYANT. Syn. Kame-no-Kegoromo (Japan) 8.5. Uniformly shaped petals of violet-crimson, a shade lighter than King of England, with center a full ball of half-transformed staminodes, chamois-yellow edged gold and faced with red of the same shade as the outer petals. The carpels are reddish-green, tipped rose-red. Tall, strong, vigorous, with rich green foliage slightly ruffled.

$\$ 2.50$

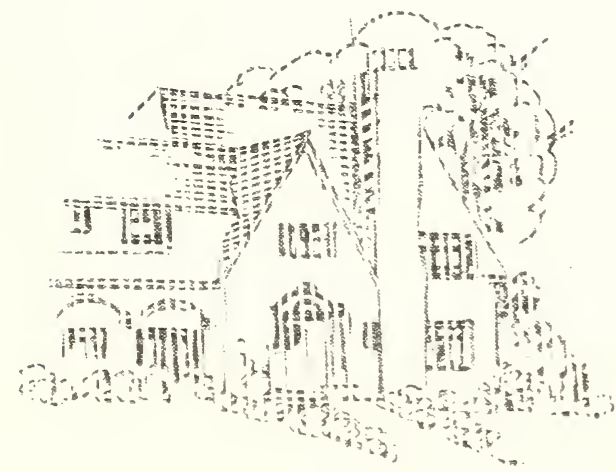

FUYAJO (Japan) 9.2. One of the most distinct and desirable of all the Japanese varieties. The single row of outer petals is dark, rich, mahogany-red, surrounding a full center of almost fully transformed, broad, flat petaloids of the same dark red as the outer petals, veined on the reverse side and tipped chamois. Carpels uniform light green. The plant is very tall and vigorous, with attractive foliage slightly ruffled and veined red.

$\$ 6.00$ 


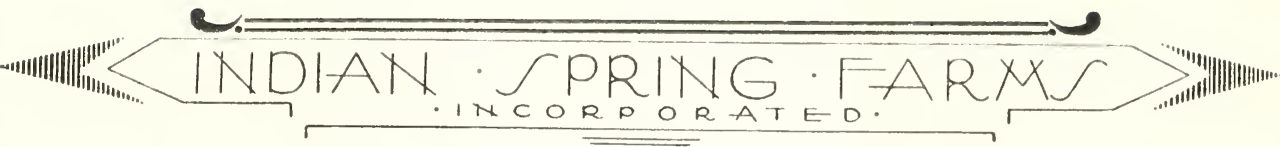

GINKO NISHIKI (Japan). A curiously colored flower that is nearly a true single in form but distinctly "Jappy" in appearance. The petals are white and artistically streaked and striated with crimson carmine. A desirable plant with clear green foliage.

$\$ 4.00$

GOLDEN NUGGET (Pleas 1913) 7.4. An interesting landscape variety that produces a striking deep orange-yellow effect when the flowers are freshly opened. The guards are rosy-lilac and the center a mass of fully transformed, narrow petaloids that are rich orange-yellow on first opening, changing to creamy-white. Deliciously sweet scented.

$\$ 4.00$

ISANI GIDUI (Japan) 9.3. Both in plant and flower, this is a variety of great beauty. The flowers are very large, with a single row of perfectly rounded, pure white petals of remarkable substance. Its center is a globular ball of narrow, incurved staminodes, white, edged and tipped with gold. It is medium tall and vigorous in growth, with gracefully curved stems that carry the large blooms in pleasing style. The foliage is distinctly ruffled.

$\$ 10.00$

KAME-NO-KEGOROMO. See Flamboyant.

KING OF ENGLAND (Kelway 1902). The broad, rounded petals of uniform dark madder-red are arranged in a single row around a center of partially transformed staminodes which are chamois-yellow, slightly streaked red. The plant is of tall growth, with small, dark green foliage.

$\$ 5.00$

KUKENU JISHI (Japan). This comparatively new variety is one of the finest introductions of recent years and is one of the most beautiful of all the Japs. When rated, it will undoubtedly stand at the head of the list of pink Japs along with Tamatbako. The delicate flesh-pink guard petals are large. smooth and evenly rounded, of unusual substance and have a satiny sheen that is very beautiful. They are arranged in cupped form and the edges are gracefully ruffled, or fluted. The center is a perfect sphere of half transformed staminodes of clear straw-yellow, faced flesh-white and edged with gold. The carpels are clear light green, set in a base of creamwhite, and tipped yellow. These unusual flowers are borne on a plant of good, upright habits that has the characteristic ruffled foliage of many of the Japanese Peonies.

$\$ 15.00$

MIKADO (Japan) 8.6. The original plant of this fine Peony came to America with the Japanese exhibit at the World's Columbian Exposition in Chicago in 1893. The outer petals are a uniform shade of crimson and surround a center of broad, partially transformed staminodes of chamois-yellow, faced crimson. It is an ideal landscape plant, strong and upright, with foliage so placed that it forms a distinct dome-shaped plant from which the flowerstems protrude, holding the blooms well above the foliage. If only one Japanese Peony is bought, let that one be Mikado.

$\$ 2.00$

NAUBUNISHISKI (Japan). A curious and interesting variety, introduced by Dessert, which is a true single rather than Japanese type. Evidently Mr. Dessert classed it as Russian, judging from the name he gave it. The irregular shaped white petals are grotesquely striated and streaked carmine, and the center stamens have the golden hue of a Cossack's whiskers. $\$ \mathbf{\$ 1 . 0 0}$

O-FUGI (Japan) 6.9. A strong-growing variety that produces its flowers of medium size on strong, upright stems. The cupped guards are delicate flesh-pink, and the center of fully transformed filamentous petals is white, tinted straw-yellow, surrounding the inconspicuous carpels of light green, tipped white. 


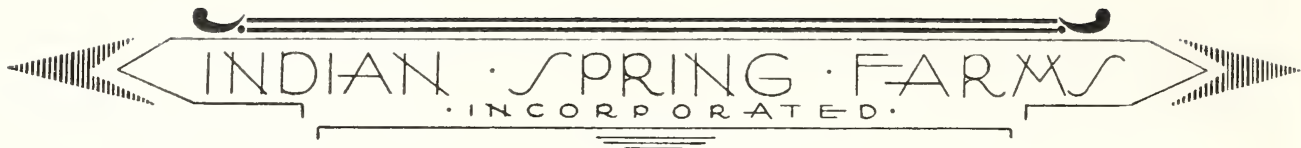

ONAHAMA (Gumm 1923). A distinct and desirable variety that is destined to win a place among the finest of the Japanese Peonies. The flowers are very large and uniform with a single row of smooth petals, cupped at the tips, of brilliant bluish crimson and a full, rounded center of partially transformed staminodes, faced with crimson and heavily bordered chamois. Tall, upright plant of imposing growth that is desirable in decorative plantings. Midseason.

$\$ 10.00$

ORANGE PRINCE (Pleas 1909). Guards deep rose-red; center, narrow filamentous petals, bright golden orange. A showy variety particularly desirable for landscape effect. A plant of vigorous growth and good habits.

$\$ 2.00$

PRINCESS DULEEP SINGH (Kelway) 8.7. This desirable variety is rated as one of the best deep pink Japanese Peonies. In both flower and plant, it is quite similar to Ohirama and Dog Rose but differs from either in its center. The guard petals are broad, evenly rounded and cupped, a soft shade of deep violet-rose that shades lighter at the edges of the petals; center, a spherical tuft of partially transformed staminodes, faced rose and irregularly edged gold. The flower has much substance, is large in size and holds well on the plant or when cut. The plant itself is tall, strong and well set with rich dark green foliage.

$\$ 3.00$

PURITY (Bunting). A charming flower with a single row of guard petals of pure white, cleft at the ends and cupped. The center is filled with short, partly transformed petaloids that are pale sulphur-yellow on opening, changing to white; carpels pinkish-green, tipped coral. The flowers are held erect on a plant of compact, upright growth.

$\$ 2.50$

RASHOOMAN (Japan) 8.7. By those who know this beautiful Peony, it is regarded as one of the best of the red Japs. The flowers are well formed and have a bright color that holds in the sun. The plant itself is most desirable because of its perfect habits and its beautiful, rich green foliage. The guard petals are a shade of bright crimson, between that of Mikado and King of England; center partially transformed staminodes, long and incurved, deep chamois color, faced crimson the same shade as the guards.

Red Peonies are always popular and the red Japs are particularly so. $\$ 5.00$

Nothing is more gorgeous in a garden than a well-established plant of one of these varieties in full bloom with a large flower of red and gold on every stem, held gracefully above the rich green foliage. Akashagata, Mikado, Rashooman, King of England and Some Ganoko all are good reds, each different in color and plant.

RUTH FORGE (Shaylor 1924). A true Japanese type flower of bright coloring that holds well until the petals fall. The broad guards are bright cerise pink, surrounding a ball center of partially transformed staminodes of yellow, edged with the same bright pink of the petals. Late midseason.

$\$ 4.00$

SIR MADHO SINGH (Kelway) 7.8. A well formed flower of medium to large size with guard petals of bright china pink that shade lighter at the edges and a center of partially transformed staminodes edged with bright gold. A desirable variety of bright pink color.

$\$ 3.00$

SNOW WHEEL. A medium-sized flower with broad, waxy guards of clear white and a center of loose filamentous petals, fully transformed, long and irregularly pointed, giving a distinct feathery effect. Carpels dark, tipped reddish. 


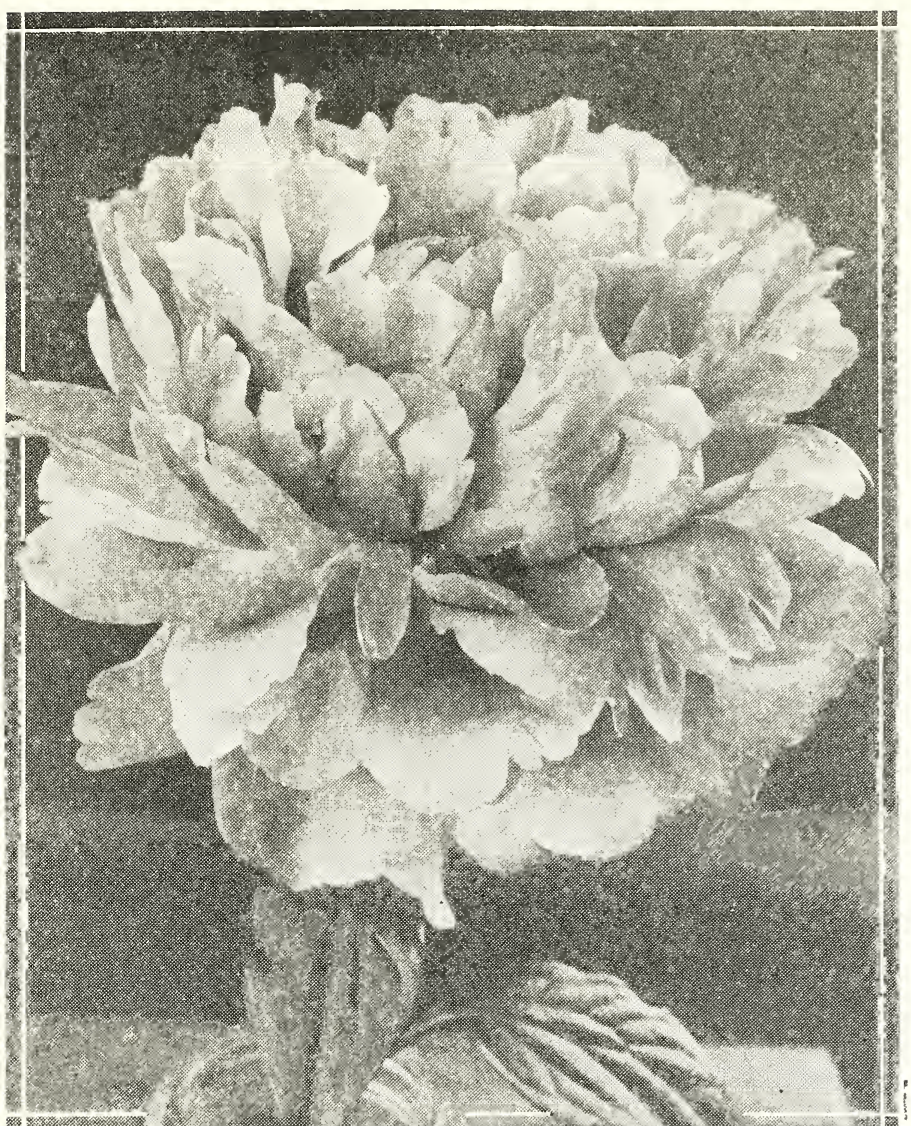

$\left.\left\{\begin{array}{c}\text { H. A. HAGEN } \\ \text { A good deep pink flower, } \\ \text { borne on a plant of ex- } \\ \text { cellent habits }\end{array}\right]\right\}$

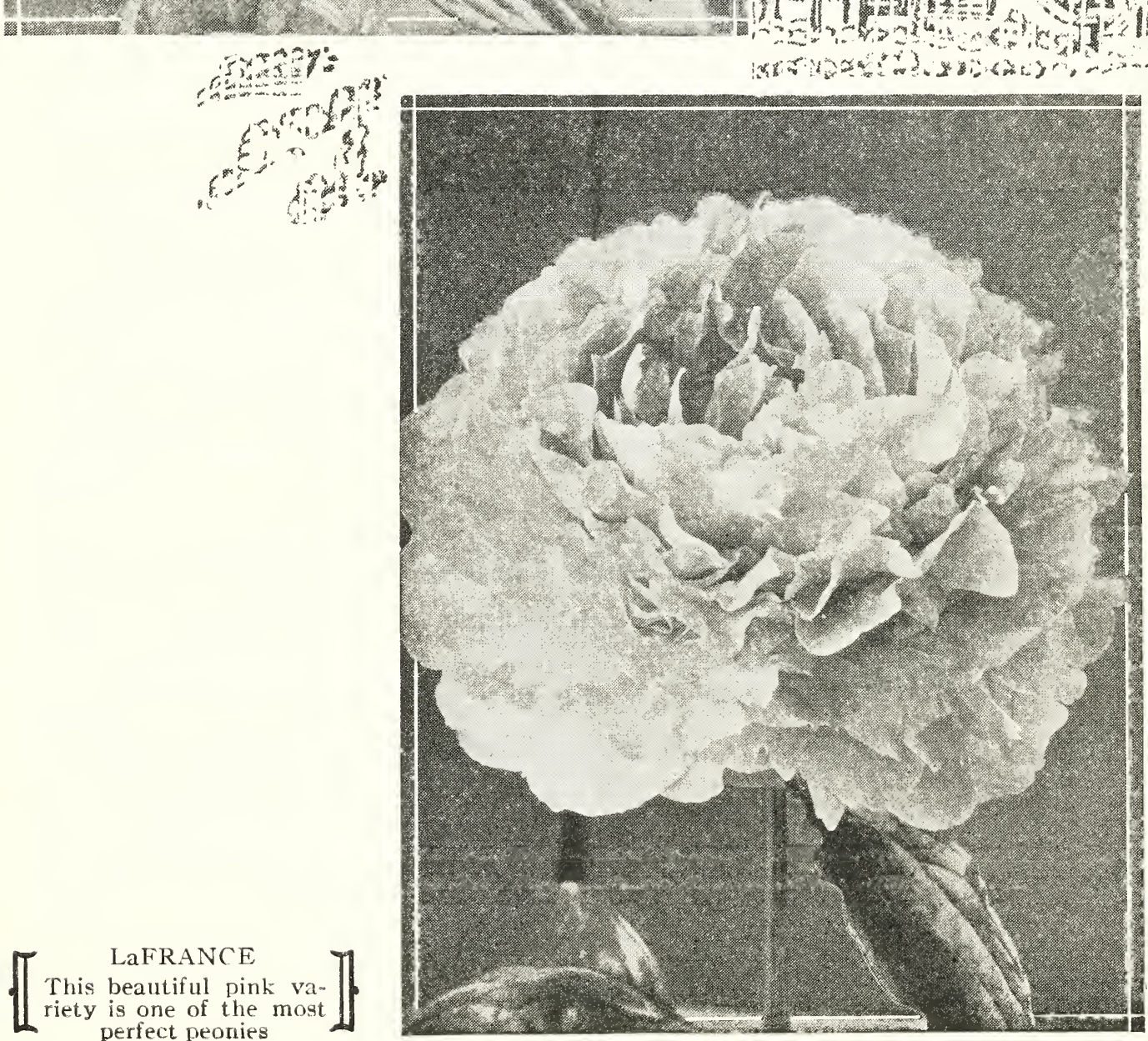




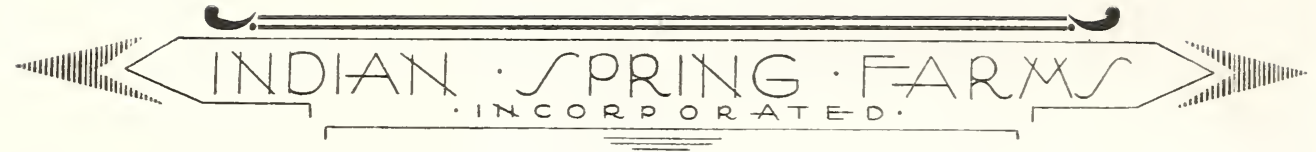

SOME GANOKO (Japan) 9.0. Judged from the ratings, this is the best red of all the Japs. The large, uniformly shaped guards are a rich shade of velvety, dark madder-red, a little darker than King of England. The center is a shapely cushion of incurved, partially transformed staminodes of golden-yellow, slightly streaked red. The plant is medium tall with graceful, upright stems well set with distinct, ruffled foliage.

$\$ 5.00$

TAMATBAKO (Japan) 9.4. Of all the Japs, this beautiful variety is held in the highest esteem. Unfortunately it is a slow grower and comparatively hard to propagate so that even at the present price it will be some years before the supply will equal the demand. It is the largest of all in size of the flower, and blooms very late, along with Marie Lemoine. The uniformly shaped petals are long and cupped at the tips, forming a flat dish of bright carmine-pink in which is placed an attractive center of partially, transformed staminodes, yellow at the base, shading lighter, and light pink at the ends irregularly crinkled and margined gold. Carpels conspicuous, light green, tipped light red and set in a base of coral-pink. The whole flower has much substance and is borne erect on stems of medium height that are furnished with heavy, dark green foliage.

$\$ 25.00$

TOKIO (Japan) 8.9. A fine pink flower of a shade slightly lighter than Amano-sode. The guards are broad and rounded, and the center is made up of half transformed staminodes, broad and crinkled, faced light pink. The growth is strong and vigorous, making a plant that is very attractive.

TORO-NO-MAKI (Japan) 9.0. This variety opens with its perfectly formed guard petals a delicate flesh color that changes quickly to lilac-white. The center is a pleasing ball of partially transformed staminodes, white edged yellow. Good, upright growth.

$\$ 10.00$

The three white Japs-Isani Gidui, Margaret Atwood and Toro-no-Makiare very similar in flower, but are distinctly different in their plant growth. All are good. White Lady is also in the same quality class but is dwarfer in growth and a slower propagator.

TORPILLEUR (Dessert 1913) 8.0. A distinctly Jappy variety that is quite different in color from all the other varieties. The well shaped guard petals are uniform deep bluish red, or wine color, and surround a center of almost completely transformed petaloids of the same color, minutely tipped with yellow. The carpels are greenish, tipped bright red. Strong plants frequently throw a fully developed "feather" petal among the center petaloids.

$\$ 4.00$

WHITE QUEEN (Wallace). A fine, all-white variety that is not as well known as it deserves to be. The flowers are very large size with broad guards of good substance and a full, ball center of wholly transformed filamentous petals that open light canary-yellow and change to clear white. Carpels are light green, tipped cream and are inconspicuous. On established plants the flowers are large, perfect in form and very beautiful.

$\$ 5.00$

YESO (Japan) 7.7. A charming variety of medium size in which the guard petals open flesh-white, quickly changing to pure white. The center is a cushion of fully transformed petaloids of sulphur-yellow, changing to pure white and finishing with distinct carmine tips similar to the petals of Altar Candles. Carpels light green, tipped pink. Vigorous and very upright, carrying its flowers on stems of uniform height. A good landscape variety. 


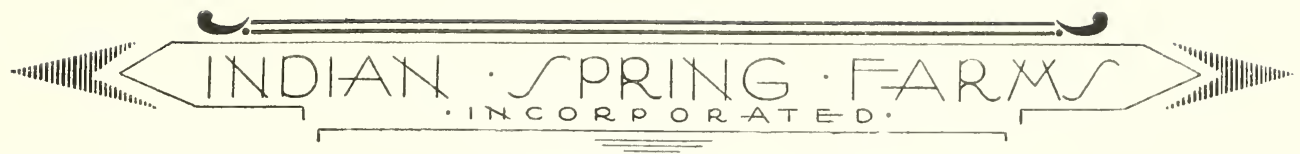

\section{Early May-Flowering Peonies}

In this group, we offer the Tenuifolias and the Officinalis species which bloom from one to three weeks earlier than the Chinensis Peonies. The plants and the flowers are very attractive and they are desirable because they add to the length of the Peony season.

OFFICINALIS ROSEA PLENA. This is the pink form of the Officinalis family. The large blooms of bomb form have broad, rounded guards well differentiated from the globular center of irregular formed petals. The flowers open a uniform shade of deep carmine-rose and shade lighter in the sun. A desirable variety for early cut-flowers that blooms ten days before the earliest Chinensis Peony.

$\$ 1.00$ each

OFFICINALIS RUBRA PLENA. The old-fashioned red "Piney" that has been grown in the door yards for years to keep the witches away. The flowers are large, bomb type, of a brilliant amaranth-red not equalled in any of the newer varieties. A dwarf plant of spreading habit with distinct Officinalis foliage. In flower ten days before the Chinensis varieties.

$\$ 1.00$ each

TENUIFOLIA FLORA PLENA. A very attractive species that blooms very early. The flowers are small to medium size, full double, a brilliant dark crimson. A dwarf plant that has distinct, finely laciniated foliage. In early spring the plant forms a perfect globe of green that is very effective in the garden, and then dies down in early summer as the plant becomes dormant. This is commonly known as the "fern leaved" Peony.

$\$ 3.50$ each

TENUIFOLIA LATIFOLIA. A single form of the Tenuifolia species. The large, single flowers come several days earlier than the double variety, a bright rose-red color, in brilliant contrast to the centers of yellow stamens, and literally cover the plant, making a brilliant landscape effect. The foliage is laciniated, but somewhat coarser than that of the double variety, and dies down in midsummer.

$\$ 2.00$ each

\section{An Invitation}

Visitors are welcome at Indian Spring Farms. We extend a cordial invitation to you to visit us at your convenience and to enjoy with us the different flowers as they bloom in season. Many rare and interesting varieties will bloom in our test plantings this year that possibly can not be seen elsewhere.

One mile west of the village of Baldwinsville on the RochesterSyracuse highway. 


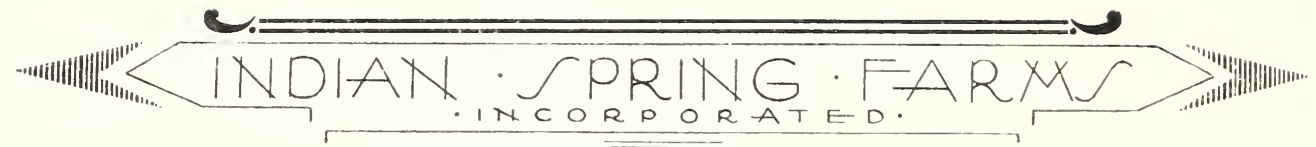

\section{Recommended Peonies for Landscape Use}

\section{WHITE VARIETIES}

Alsace Lorraine

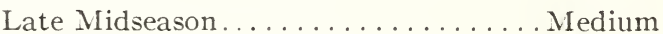

A. M. Slocum

. Midseason....

Medium

A. P. Saunders

Avalanche

Late Midseason

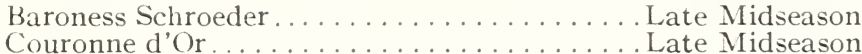

Couronne d'Or.

Enchanteresse.

Frances Shaylor

Late

... Tall

Frances Willard

Late Midseason.

Medium

Medium

Frankie Curtis.

Midseason.

Tall

Golden Dawn

Kelway's Glorious

La Rosiere.

Midseason.

Dwart

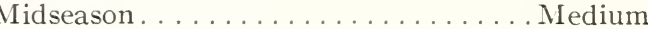

Laura Dessert

Le Cygne.

Early Midseason

Midseason.

Midseason.

Medium

Medium

Marie Jacquin

Marie Lemoine.

Midseason

Midseason .

Late

Medium

Midseason.

edium

Mlle. Jeanne Reviere

Midseason

Dedium

Marcelle Dessert

Late Midseason

Early Midseason

Medium

Monsieur Dupont

Mrs. Edward Harding .

Midseason.

Tall

Nymphaea

\section{ARIETIES}

Albert Crousse

Alexandriana

Charles Verdier

Chestine Gowdy .

Coronation.

Cornelia Shaylor

E. J. Shaylor

Edulis Superba.

Edwin C. Shaw .

Elwood Pleas. .

Eugene Verdier

Exquisite (Kelway)

Georgiana Shaylor.

Germaine Bigot.

Ginette.

H. A. Hagen

Jeannot. . . .

June Day

Kelway's Queen

Katharine Havemeyer

La Fee.

La Fontaine.

La France.

La Perle.

Lady Alexandra Duff

Lillian Gumm .

Loveliness

Mabel Franklin

Mary P. King .

Mary Woodbury Shaylor

Mignon

Milton Hill

Miss Salway

Martha Bulloch

Mme. Auguste Dessert

Mme. Calot

Mme. D. Treyeran

Mme. Ducel.

Mme. Emile Galle.

Mme. Jules Dessert

Octavie Demay.
Late Midseason

Early ............

Late Midseason

Late Midseason

Late.

Late Midseason

Early

Late Midseason

Late Midseason

Late Midseason

Midseason.

Midseason.

Midseason.

Midseason.

Late

Late.

Midseason.

Midseason.

Late Midseason

Early Midseason

Late Midseason

Late Midseason

Late Midseason

Early Midseason

Late Midseason.

Late

Midseason

Midseason

Midseason

Midseason.

Late.

Midseason.

Late.

Midseason

Early

Early Midseason

Midseason.

Late Midseason

Late Midseason

Early.
Medium

Medium

Medium

Tall

Medium

Tall

Medium

Medium

Medium

Medium

Medium

Tall

Medium

Medium Dwarf

Medium

.Tall

Medium

Medium

Medium

Tall

Medium

Tall

Medium

Medium

Medium

Tall

Medium

Medium Dwarf

Medium

Medium

Medium

Tall

Medium

. Tall

Dwart

Medium

Medium

Tall 


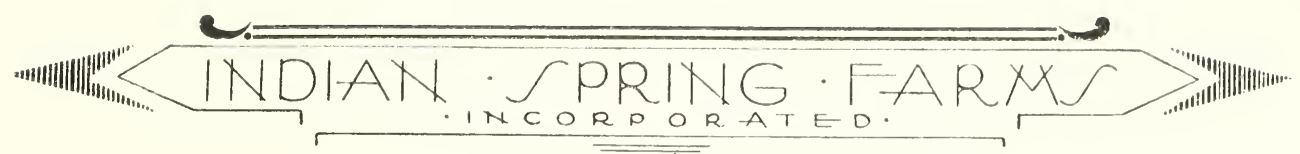

Opal

Late Midseason

Medium

Pasteur

Late Midseason

Tall

Phoebe Carey

Late.

Tall

Phyllis Kelway

Midseason

Medium

Pierre Ducharte.

Late.

Medium

Pride of Essex.

Midseason .

Medium

Raoul Dessert.

Midseason

Medium

Rosa Bonheur

Midseason

Medium

Rose Shaylor.

Late

Medium

Rosette. .

Midseason

Medium

Early ....................... Medium

Silvia Saunders. . . . . . . . . . . . . . . . Early

Dwarf

Souvenir de Louis Bigot................ Midseason

Medium

Suzette

Midseason

Medium

Therese . Midseason

Medium

Umbellata Rosea . . . . . . . . . . . . . . . . Early .... .

Medium

\section{RED VARIETIES}

Adolphe Rousseau

Early

Tall

Auguste Dessert.

Midseason

Medium

Augustin d'Hour

Late Midseason

Medium

Midseason . Medium

Brand's Magnificent

Midseason

Medium

Cherry Hill

Midseason

Tall

Midseason . . . . . . . . . . . . . . . .

Charles McKellip

Early

Medium

Midseason . . . . . . . . . . . . . . Medium

Midseason.................... Medium

Karl Rosenfield.

Midseas

Medium

Mary Brand

Midseason .

Medium

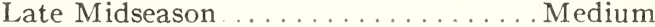

Philippe Rivoire.

Rachel (Terry)

Midseason . . . . . . . . . . . . . . Medium

Early....................................

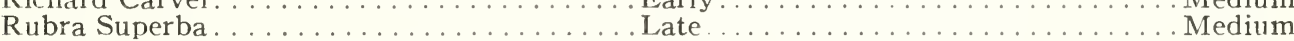

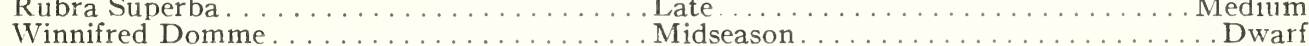

William F. Turner. . . . . . . . . . . . . Early.................... Medium

\section{Approved Peony Collections}

As an aid to beginners in Peony growing and those busy people who haven't time to study catalog descriptions, we have assembled the following collections. We offer them with our assurance that each variety is a good one, selected from the hundreds of different Peonies, on its merit alone, as one of the best for the purpose mentioned.

These named collections are permanent features of our business, and years of understanding love for Peonies have guided us in their make up. Each is intended to reflect a lasting credit to the good will of Indian Spring Farms.

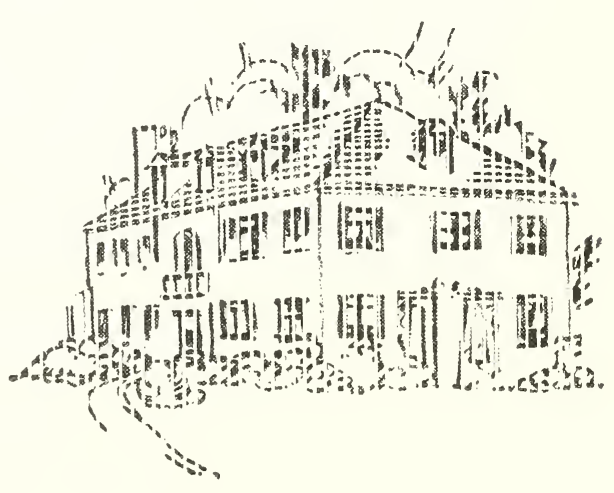




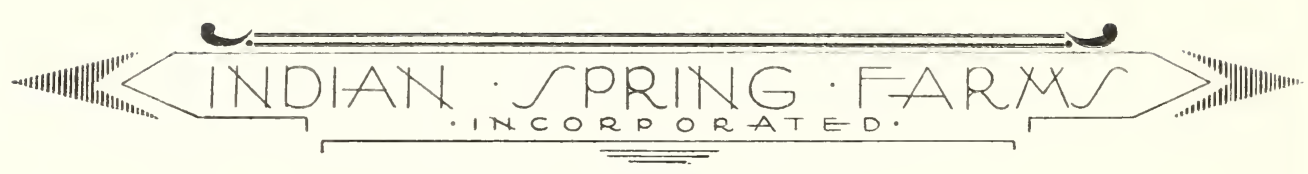

\section{The "Four Veterans"}

In all the peonies, four varieties stand out with distinction as worthy veterans of the battle for the survival of the fittest. These are old varieties that have stood the test of time, and of which there has accumulated sufficient growing stocks to warrant low prices. Each is rated high in its respective color class, and together they form the profitable basis of most commercial plantings. As first choice, plant these "four veterans."

Festiva Maxima. A wonderful, large, full double flower of clearest white, with occasional markings of bright crimson on the central petals, as though to accentuate by contrast the marvelous purity and beauty of the bloom. Delightful June rose fragrance . . . . .

Edulis Superba. The Great Decoration Day Peony! A very large, loose, deep mauve-pink variety that blooms early and freely. One of the most delightfully fragrant of all the peonies. Valuable for early cut flowers

Monsieur Jules Elie. One of the largest and most perfectly formed flowers yet produced. The immense, globular, chrysanthemum-like blooms of silvery rose-pink are freely produced on a plant of vigorous growth and fine foliage. A wonderful show flower and a truly great peony

Felix Crousse. A red that is a worthy companion to these other fine peonies. The large, globular, bomb-type flowers are symmetrical in form and have a brilliant ruby-red, or Tyrian-rose, color that is most attractive. Midseason

This "Four Veterans" Collection - a white, two pinks and a red, for $\$ 3.00$

\section{The "Backbone" Collection}

Here is our selection of the dozen best peonies for a first-garden planting. We call it the "Backbone" Collection because each variety is of outstanding merit and will always have a place in every well selected peony planting. It is an ideal foundation around which to build. For your own garden, or as an appreciative gift to a friend, you will find this "Backbone" Collection a most appropriate purchase. Each is an Approved variety.

\section{The Twelve Best Peonies at Reasonable Prices}

James Kelway. Fine flesh-white. Early

Marie Jacquin. The water-lily peony. White. Midseason . . . . $\mathbf{1 . 5 0}$

Mme. Emile Lemoine. A wonderful white. Midseason . . . . . . 1.50

Baroness Schroeder. Beautiful rose-white. Late . . . . . . . . . $\mathbf{1 . 5 0}$

Octavie Demay. Dwarf light pink. Early . . . . . . . . . . . . $\mathbf{1 . 0 0}$

Venus. Refined shell-pink. Midseason . . . . . . . . . . . . . . 1.50

Reine Hortense. Very large pink. Midseason . . . . . . . . . . $\mathbf{1 . 5 0}$

Mme. Emile Galle. Delicate flesh-pink. Late midseason . . . . . . 1.00

Claire Dubois. Large, deep violet-rose. Late . . . . . . . . . . 1.00

Sarah Bernhardt. A divine pink. Late . . . . . . . . . . . . . 2.00

Karl Rosenfield. King of the reds. Midseason . . . . . . . . . . $\mathbf{1 . 0 0}$

Adolphe Rousseau. Gorgeous dark red. Early midseason . . . . $\quad \mathbf{1 . 5 0}$

This "Backbone" Collection, $\$ 13.50$ 


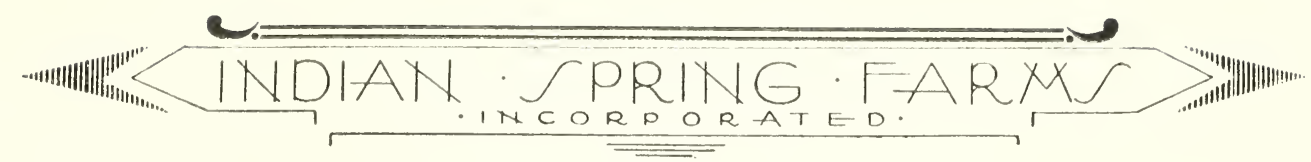

\section{The "Good Ten" Collection}

Here are ten good peonies that have proven their worth. We regard them as the best of the standard varieties now obtainable at reasonable prices. All are free and reliable bloomers that are sure to please.

Mme. de Verneville. Early white

La Rosiere. Midseason white

Monsieur Dupont. Late midseason white

Marie Lemoine. Late white

Asa Gray. Early light pink.

Mme. Ducel. Midseason deep pink

Marguerite Gerard. Midseason light pink

Livingstone. Late medium pink

Benjamin Franklin. Midseason dark red

\section{The "Six Favorites"}

These six desirable peonies are admirably adapted for a small garden planting and will return heavy dividends of pleasure on the modest capital investment. Combined with the "Four Veterans," they will afford a pleasing variety of flowers throughout a long blooming season.

Avalanche. Large globular flowers of purest white with a charm enhanced by minute tracings of red on occasional center petals. A free blooming and reliable late midseason variety

Couronne D'Or. A charming white variety distinguished by a ring of yellow stamens partially concealed among the clear white petals reflecting a true "Crown of Gold."

Ruth Brand. A vigorous and free flowering variety that affords a wealth of refreshing light pink blooms in midseason. Delightfully fragrant.

Albert Crousse. The distinct ball-like flowers of refined texture and soft shell-pink color make this an outstanding late peony. Equally desirable in the garden or for cutting.

La Perle. An interesting peony done in two-tone pink. A broad zone of soft lilac-white petals surround a globular center of deeper rosepink petals on which is found an occasional mark of red. Very beautiful.

Lord Kitchener. Bright cherry-red flowers of loose bomb shape that will enliven the color effect of any planting. A desirable variety that is somewhat rare. 


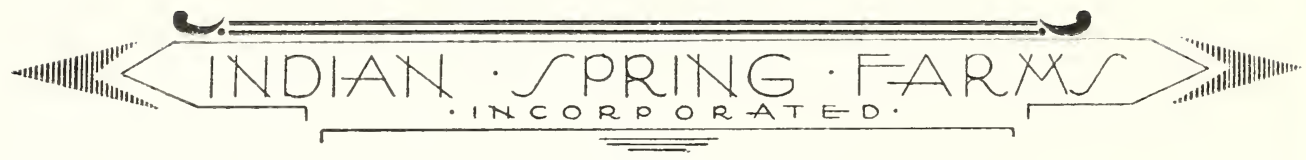

\section{The "High-Nine" Sextette}

In this collection, we offer six of the very finest peonies in the world. Not only do they rate high in the American Peony Society Symposium, but they are among the prize-winners in every Peony Show. Our enlarged plantings enable us to offer these desirable varieties during 1928 at a pleasing reduction from their former prices.

Rating

9.9 Le Cygne. The world's finest white peony

9.8 Kelway's Glorious. A wonderful white, distinctly different from Le Cygne and equally as good

9.8 Therese. The largest and finest of all pinks

9.3 Walter Faxon. A beautiful flower of distinct bright pink color .

9.7 Solange. Deep cream with a salmon reflex from the depth of the petals

9.0 Longfellow. A brilliant red that outshines all others in that color class

Special “High Nine” Collection, \$22.50

Total $\$ 26.00$

\section{"Six-of-the-Best" Collection}

Certain Peonies are of such distinct and outstanding merit that they are essential in every garden that pretends to have the best. Six such peonies have been selected to make up this collection. Each holds a prominent and undisputed position in any list of the finest varieties, and we can conscientiously recommend them to anyone who wants a few of the best.

Frances Willard. A magnificent white flower that pays worthy tribute to that grand character whose name it bears

Mme. Jules Dessert. This delightful flower has an ethereal coloring that is hard to describe. Its opalescent tints are both white and pale pink with a dash of straw-yellow that is bewitching

Lady Alexandra Duff. The famous "Lost Peony." A very large flat flower of variable form and a delicate pink coloring that changes to white

Milton Hill. A fine late variety of large size and delicate beauty. A very remarkable show flower.

Richard Carvel. The best early red. Large, bomb shaped flower of uniform bright crimson

Monsieur Martin Cahuzac. The "black" peony. A striking flower of very dark purple-garnet coior that is very distinct.

This "Six-of-the-Best" Collection, $\$ \mathbf{1 3 . 5 0}$ 


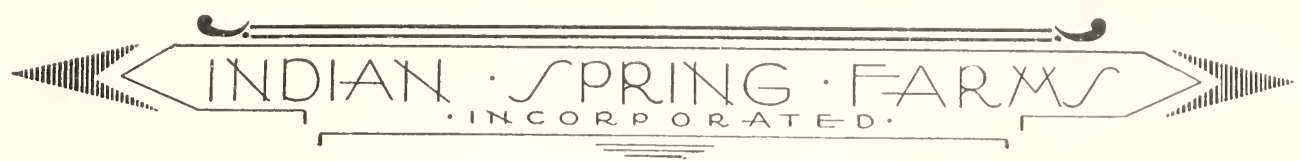

\section{The "Bargain Dozen"}

\section{Twelve Beautiful Peonies for $\$ 5.00$}

This special offer is made as an inducement to beginners to plant peonies. From our surplus stocks of our catalog list and from the numerous small lots in our plantings, which for one reason or another we do not wish to propagate further, we will select twelve good varieties that will afford as wide a color range as possible and give an extended season of bloom. Each root will be a strong division having two to five eyes, separately labeled and true to name. As these collections will be assembled on a quantity basis at digging time and will not all be alike, we cannot give names of the varieties or make special color selections other than the regular packing. Shipment by express after September 15. If wanted by parcel post, add 50 cents.

\section{Single Early Tulips}

These gay and friendly flowers are the first of all the Tulips to come into bloom. Their bright, cheerful colors are fitting heralds of the weeks of Tulip splendor that follow. Their season begins along with the hyacinths and narcissi, and they add to a garden planting the more brilliant colorings lacking in the other seasonable flowers.

The early Tulips are at their best when used in mass effect. Their old fashioned primness and their clear colors make them ideal for all bedding purposes, but they are equally effective when grouped in the borders or clustered before the shrubbery.

Belle Alliance. Fine early scarlet, large, sweet scented.

9 inches.

Brilliant Star. Brilliant vermilion-scarlet. An early variety of fine form and substance. 9 inches...

Couleur Cardinal. Soft, velvety crimson-scarlet, with a flush of plum-purple on the outside. Fine, globular form. Very beautiful. 13 inches .

Vermilion Brilliant. Large, dazzling vermilion-scarlet flower of fine form. 9 inches 
Goldfinch. A splendid deep golden yellow, sweet scented, 14 inches

Mon Tresor. Fine pure yellow of beautiful form. The best yellow for bedding. 13 inches . . . . . . .

Yellow Prince. A desirable yellow, sweet scented. 9 inches

\section{SINGLE WHITE}

Lady Boreel. Syn. Joost van den Vondel White. A long, slender flower of beautiful form. One of the finest early whites for bedding. 14 inches.

L'Immaculee. Pure white. A fine forcing variety. 10 inches

Pelican. Large, pure white, very fine. '10 inches . . .

White Beauty. One of the finest whites, a pure white sport of pink beauty. 12 inches

White Swan. Large pure white of oval form. One of the most graceful early Tulips, desirable for cutting. 5 inches

\section{SINGLE PINK AND ROSE}

Pink Beauty. A large and beautifully formed flower of deep rose pink, shaded lighter at the borders. One of the very best. 12 inches

Flamingo. Very beautiful carmine-rose, with a white stripe through each petal. 13 inches

Le Reve (Hobbema). Beautiful soft rose, with a blending of buff. Handsome for outdoor planting. Late. 13 inches

\section{SINGLE ORANGE AND SCARLET}

Keizerskroon. Very large scarlet-red flower, edged with a broad margin of yellow. A favorite for bright color. 16 inches

De Wet. Beautiful deep orange, with unusual golden salmon shadings produced by scarlet veinings. Very fragrant and one of the finest early Tulips. 15 inches

\section{Special Offers of Single Early Tulips}

SINGLE EARLY TULIP MIXTURE. This is the finest mixture obtainable both in quality of bulbs and variety of flowers. Recommended for quantity planting where a wealth of cheerful color is wanted.

75 cts. per doz.; $\$ 2.50$ for $50 ; \$ 4.50$ for $100 ; \$ 40.00$ for 1000 .

SINGLE EARLY TULIP COLLEGTION A-5. Five bulbs each of 10 varieties ( 50 bulbs in all), each variety packed and labeled separately, selected to give a full range of colors, for $\$ 3.75$.

SINGLE EARLY TULIP COLLEGTION B-12. One dozen bulbs each of 10 varieties ( 120 bulbs in all), each variety packed and labeled separately, selected to give a full range of colors, for $\$ 7.75$. 

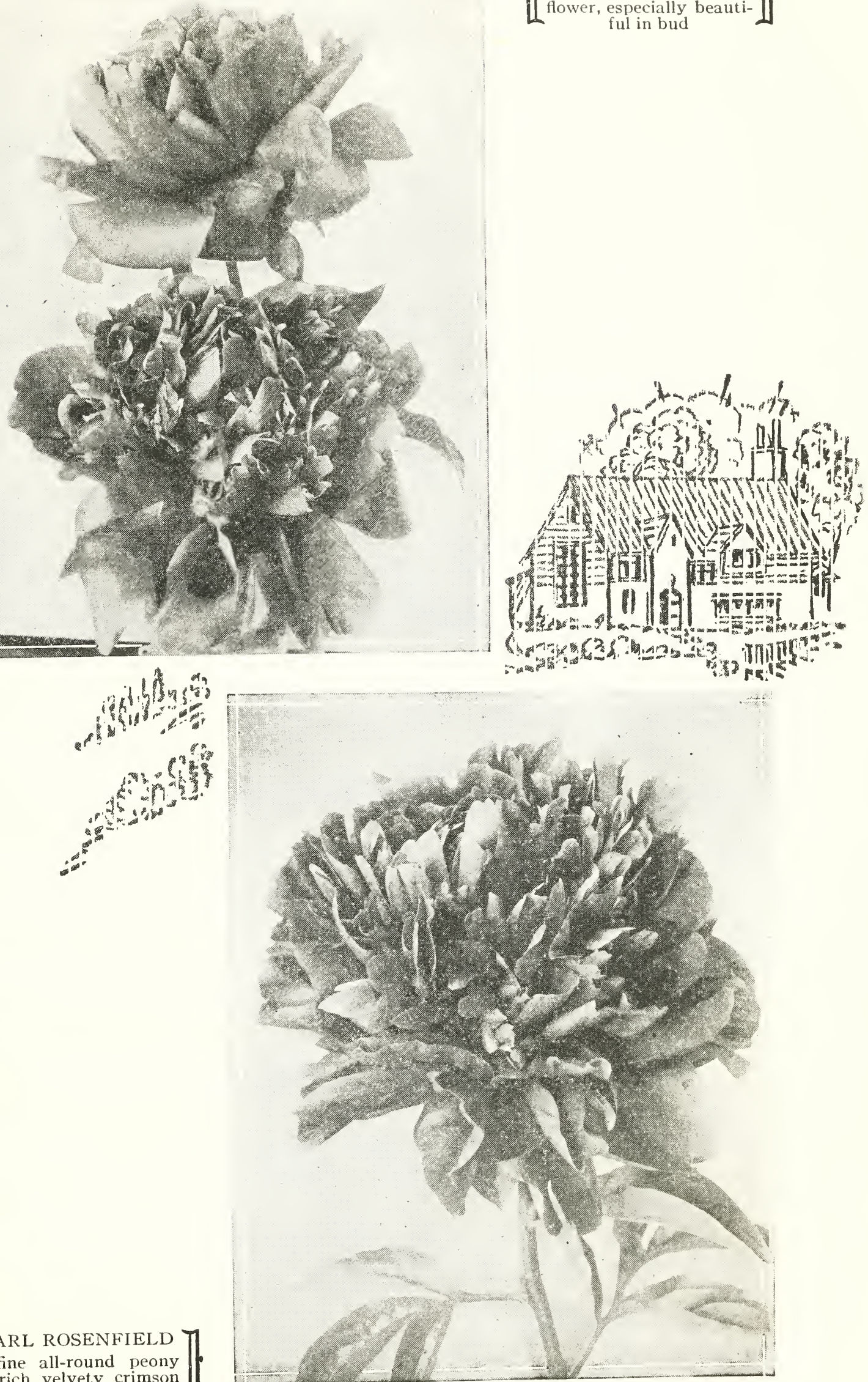


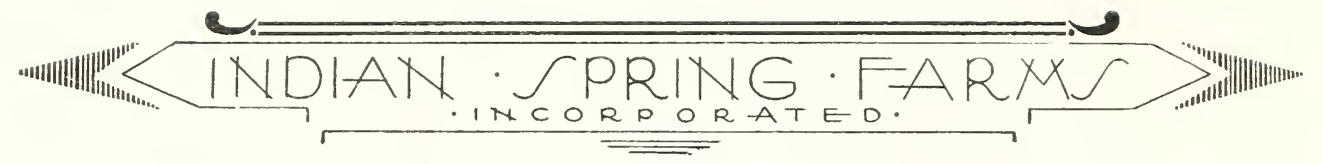

\section{Double Early Tulips}

These charming Double Early Tulips come into bloom with the last of the Single Early varieties and carry on the season until the May-flowering Tulips are ready. They are more robust than the single varieties and last much longer in the garden. Their sturdy, compact growth and their broad, wide-open flowers make them especially desirable for bedding use.

Boule de Neige (White Peony). Large, pure white flower

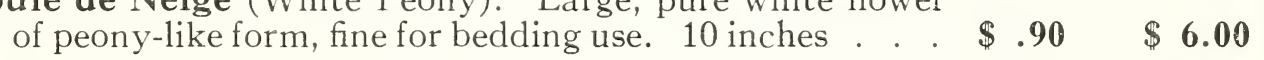

Electra. Beautiful flower of very large size. Bright rosy carmine, feathered violet. One of the best exhibition varieties

Doz.

100

1.359 .00

Mr. Van Der Hoef. A pure yellow sport of the beautiful pink Murillo. Very full double, fine in every way. 10 inches

Peach Blossom. Large, very double, bright pink flower, flushed white, that softens with age to deep rose. A superb variety. 12 inches . . . . . . . . . .

Schoonoord. The finest of the pure white doubles. A large flower of good form. 12 inches . . . . . . . . .

Tea Rose (Brimstone Beauty). A lovely blend of pale yellow and soft rose. Distinct and desirable. 10 inches.

Vuurbaak. Large flowers of bright, fiery scarlet. One of the most brilliant bedders. 10 inches

\subsection{5}

\section{Special Offers of Double Early Tulips}

SPECIAL DOUBLE EARLY TULIP MIXTURE. This is the finest mixture obtainable, and contains a wide color range of the best bedding varieties. Recommended for mass plantings where named varieties are not required. 75 cts. per doz.; $\$ 2.50$ for $50 ; \$ 4.50$ for $100 ; \$ 40.00$ for 1000 .

DOUBLE EARLY TULIP COLLEGTION C-12. One dozen each of five different varieties (60 bulbs in all), each variety packed and labeled separately, selected to give a range of colors, for $\$ 3.75$.

\section{May-Flowering or Cottage Tulips}

These beautiful Tulips bloom just before and along with the Darwins Among them we have some of the most beautiful flowers of the whole Tulip

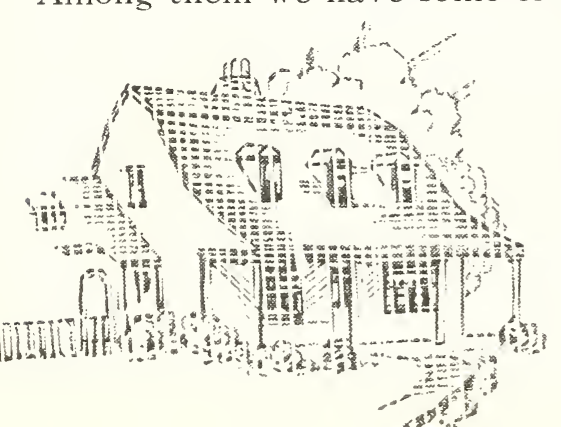
family. They are not quite as tall growing as the Darwins, but they afford a range of colorings and artistic forms not available in that class. The soft clear yellows are especially lovely and should be included in every planting. 


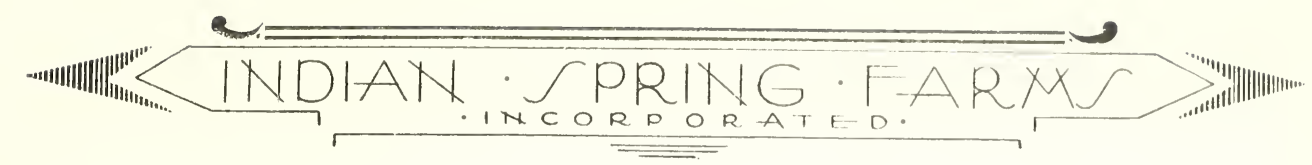

PINK AND ROSE SHADES

Inglescombe Pink. A favorite variety of clear, soft pink, tinted inside with a mber. 24 inches .

Doz. $100 \quad 1000$

$\$ \quad .60 \quad \$ 4.00 \quad \$ 35.00$

Quaintness. A lovely novelty of unusual colorings. Golden brown, overlaid with rose, the interior mahogany brown, with a yellow base. Fine pointed flower. 20 inches.

Sirene. A pink retroflexa of the same lovely shade as Clara Butt, with a shading of pale yellow. One of the Lily-flowering type that is most pleasing to those who admire the artistic. 20 inches

Striped Beauty (Syn. Summer Beauty). Rose, flaked deep crimson and white; very large and strong. 22 inches.

40.00

\section{WHITE, VIOLE'T AND FAWN}

Dora. A clear, pure white of good form. 20 inches.

Maiden's Blush (Picotee). A pure white flower of long, recurved form, beautifully margined with soft rose. A popular cut-flower variety. 20 inches

The Fawn. A fine oval-shaped variety of yellowish fawn, blended with pale rosy lavender. A lovely flower for cutting. 20 inches

Union Jack. Light violet, feathered markings of reddish lilac. A distinct and interesting flower that is beautiful with the yellows. 22 inches

\section{YELLOW SHADES}

Avis Kennicott. Very large, deep chrome yellow flower with striking black base and anthers, corne erect on a strong stem. 25 inches.

Gesneriana Lutea. A beautiful soft yellow flower of charming form that is distinctly fragrant. One of the best all around yellows. 22 inches

Inglescombe Yellow. Rich canary yellow variety of perfect, globular form borne on sturdy stems. An occasional flower shows a crimson edge. Sometimes called the Yellow Darwin. 21 inches

Moonlight. A very long flower of fine oval shape and a delightful pale yellow color. Very lovely in combination with the Darwins La Tristesse or Dream. 25 inches

Mrs. Moon. Long pointed flowers of reflexed form and clear yellow color that blooms late; tall stems. One of the best of all the yellow varieties. 25 inches 


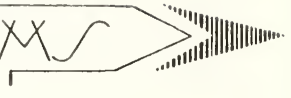

Walter T. Ware. The richest golden yellow of all the Tulips. Beautiful globular form with reflexing petals. A grand variety. 18 inches . .

Doz. $\quad 100$

1000

\section{$\$ 2.75 \$ 22.00$}

Yellow Picotee. A yellow counterpart of the lovely variety Maiden's Blush. The flowers are clear canary yellow, with a narrow border of deep rose. 20 inches

\section{Special May-Flowering Tulip Mixture}

For quantity plantings and for cutting gardens where the names of the varieties are not essential, we offer this balanced mixture of the May-flowering varieties. We recommend it for planting along with the Darwin Mixture to add variety of color and form. 60 cts. per doz.; $\$ 4.00$ for $100 ; \$ 8.00$ for 250 ; $\$ 15.00$ for $500 ; \$ 28.00$ for 1000 .

\section{Darwin Tulips}

Too much cannot be said in praise of this class of Tulips. The Darwins comprise the largest group of all the Tulip species, and are by far the most popular both for garden and indoor planting. They excel in brilliancy of colors and perfection of form, and come on long, strong stems that make them adaptable to all planting schemes. Their self-colored flowers vary from almost jet black, crimson and scarlet through purple and lilacs to mauves, pinks and delicate pastel shades. They are desirable for splendid border effects and group plantings about the shrubbery. As cut flowers, they are very beautiful with their long stems and mammoth size, and they last for many days. Once planted they may remain undisturbed for several years and afford a wealth of bloom each season.

\section{WHITE AND BLUSH SHADES}

La Candeur (White Queen). Delicate, opalescent white with a tinting of pink, and effective black anthers. Fine globular form. 24 inches

Painted Lady. Creamy white, faintly tinged soft heliotrope when opening. 27 inches

\section{PINK AND ROSE SHADES}

Afterglow. A large flower with beautiful blended colorings. Soft apricot orange, tinged with pink and shaded salmon at the edges. 27 inches .

Anton Roosen. Vivid rose pink, shading lighter toward the edges of the petals, base white marked blue. A beautiful variety with large flowers of robust growth. 30 inches . . . . .

Aphrodite. Large flower of soft rose, or silvery pink, deeper within. Regarded as the finest Darwin of its color. 32 inches . 


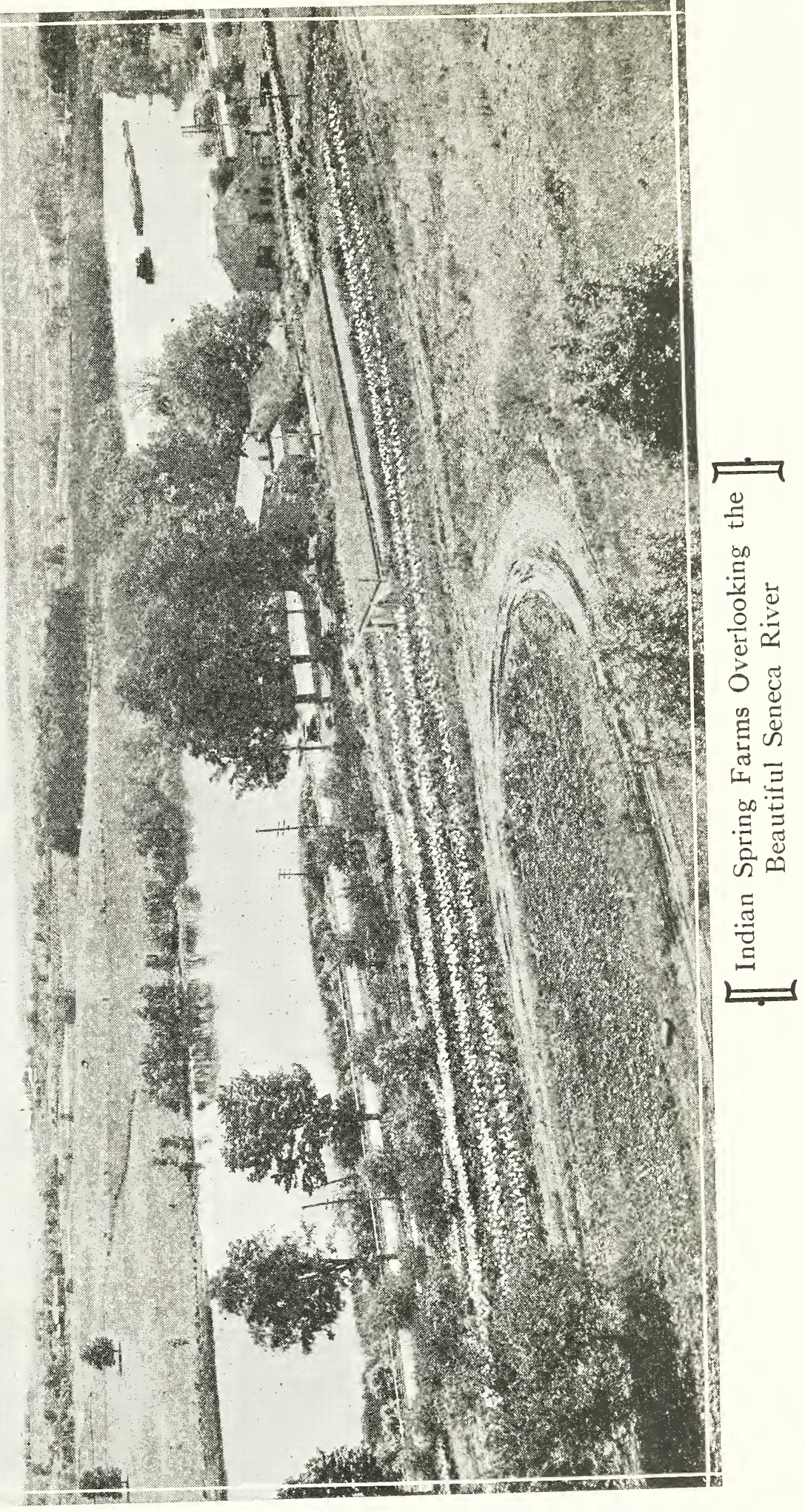




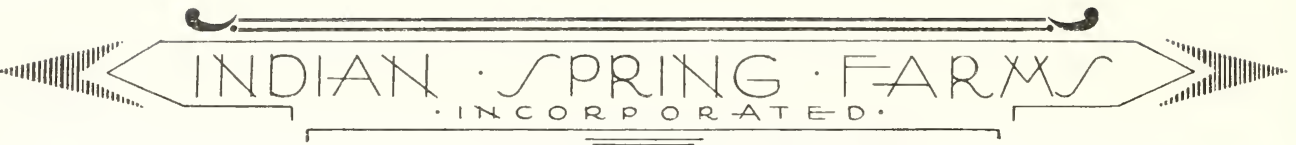

Baronne De La Tonnaye. Syn. Caliope. A large rose pink, with pale shadings towards the edges of the petals. 30 inches

Doz.

100

1000

Centenaire. Rich violet rose with large blue center. Immense flowers of perfect shape. 30 inches

Clara Butt. Perfectly formed flowers of bright, clear shrimp pink. One of the best. 24 inches.

Jefferies (Mr. Thorbecke). Extra large flower of fine form, a pleasing shade of rosy carmine. 30 inches

Le Notre. An extra early variety, soft rose, shaded blush. 27 inches . . . . . . . . . . . .

Madame Krelage. Bright lilac rose, margined pale silvery rose; inside soft rose pink. A large flower of graceful form that is effective in border plantings. 32 inches

Margaret. A very pretty, distinct globular-shaped flower, outside blush-pink, inside rather deeper shade. 27 inches

Nauticus. Glowing, dark cerise-rose, or cherrypink, center dark violet, shaded bronze. Very large and handsome. 32 inches

Princess Elizabeth. Soft, rich rose, shading to silvery rose at the edges; inside deep rose, white at the base. 26 inches

Professor Rauwenhof. Very large flower of magnificent cherry-rose color; base white, marked blue. 28 inches

Sophrosyne. A large flower of perfect form and a blending of delicate shades that is hard to describe. General effect soft rosy pink, suffused with lilac on the outside and shaded to silvery white at the borders; inside pink, with a blue base. 30 inches .

Sieraad Van Flora. An extra large, round flower, bright, rosy pink, shaded with lilac; blue base. 24 inches. Very effective.

\section{SHADES OF RED}

Bartigon. A tall, large, fiery red flower, with base white, edged with blue; very strong and desirable. 24 inches

Gity of Haarlem. A very handsome variety of large size and good substance. Brilliant scarletred, with a deep violet base outlined in white. The largest of the scarlet Darwins. 30 inches. 


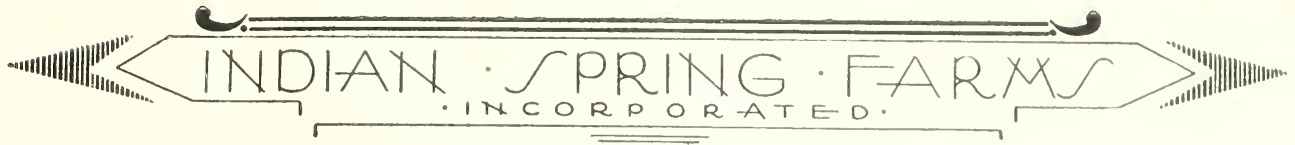

Europe. Glowing salmon-scarlet, shaded rose, Doz.

100

1000 with a white base. Erect growth, distinct and beautiful. 22 inches

Farncombe Sanders. A vivid, rosy scarlet flower of superb form and large size; inside bright cerise-scarlet, with white center marked with blue. One of the very best outdoor varieties

Isis. Bright crimson-scarlet, base blue, margined white. A tall, strong variety for effective bedding . . . . . . . . . . . . .

King George V. Immense flowers of unusual substance carried on strong stems. Brilliant scarlet, or cherry rose, slightly starred blue at the base with a white halo. 28 inches . . . . . . .

King Harold. Deep purple-red with a white base. A sturdy variety for all garden plantings. 24 inches

Loveliness. Soft rosy carmine, shaded blush. Not a large flower but a warm and brilliant color that is truly lovely. 22 inches .....

Pride of Haarlem. Bright rosy carmine, suffused with purple. A large flower of superb form, beautiful both in landscape plantings and for cut blooms. 30 inches . . . . . . .

William Pitt. Large, fine, dark velvety crimson flower with a flush of purple on the outside of the petals. A distinct color, very beautiful in the garden. 24 inches . . . . . . . .

\section{SHADES OF VIOLET AND PURPLE}

Blue Bird. A very handsome variety of a striking mauve blue shade; tall, erect stem. 30 inches

Dream. A beautiful Darwin of soft, light heliotrope tones, suffused toward the edges of the petals with silvery lilac. One of the best lavender varieties. 27 inches . . . . . . .

Faust. A large flower of splendid, long form. Dark, satiny wine purple, with a blue base. Very rich as a cut-flower or in border plantings. 30 inches

Giant. A superb reddish purple Darwin, with a white base, borne on tall, strong stems. 30 inches . . . . . . . . . . . . .

La Tristesse. Tall, slaty violet, shaded to silvery gray at the margins. Medium size and good form. 27 inches . . . . . . . . . .

La Tulipe Noire. Deep maroon black; the darkest color and finest form of the Darwins. 24 inches.

Philippe de Commines. Velvety dark maroon purple. A large flower on a sturdy stem. 26 inches 


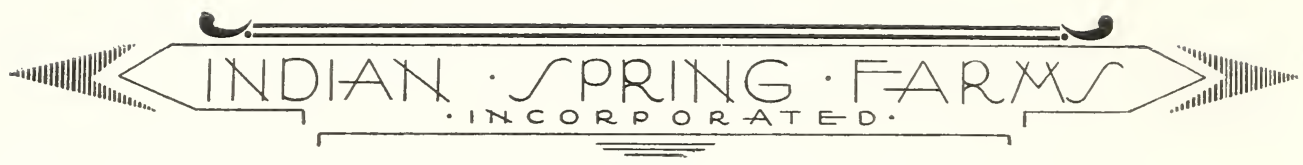

Reverend Ewbank. Lilac-mauve, shading to sil- Doz. 1001000 very heliotrope at the edges; base white. Distinct, spreading flower, lighter in color than Dream. 22 inches .. . . . . . . .

The Bishop. Finest deep violet, with a blue base, bordered white. A beautifully formed flower, very effective in contrast with yellow varieties. 28 inches

$2.50 \quad 20.00$

The Sultan. Rich maroon-black. One of the darkest Tulips. 24 inches . . . . . . . .

$.60 \quad 4.00 \quad 35.00$

Valentin. A very early and desirable variety with large, dark heliotrope-blue flowers of fine form, on very tall stems. 34 inches . . . . . . .

Zulu. Shining blackish purple, with distinct violet edge. A graceful flower with pointed petals. 27 inches

\title{
YELLOW SHADES
}

Yellow Darwin. Clear canary yellow. Not a true Darwin, but nearest in shape to be classed with them and suitable for combination plantings. 21 inches

\section{Special Offers of Darwin Tulips}

SPECIAL DARWIN TULIP MIXTURE. For mass plantings and for cutting gardens where a quantity of fine flowers is wanted without the trouble of keeping a record of named sorts, we offer this mixture. It includes a wide range of the best varieties selected to give a wide range of color and a long period of bloom. $50 \mathrm{cts}$. per doz.; $\$ 3.00$ for $100 ; \$ 7.00$ for $250 ; \$ 13.00$ for $500 ; \$ 25.00$ for 1000 .

DARWIN COLLECTION D-5. Five bulbs each of 10 varieties (50 bulbs in all), each variety packed and labeled separately, selected to give a wide range of colors, for $\$ \mathbf{2 . 5 0}$.

DARWIN GOLLECTION D-12. One dozen each of 10 different varieties (120 bulbs in all), each variety packed and labeled separately, selected to give a wide range of colors, for $\$ 5.00$.

DARWIN COLLECTION 50. Fifty bulbs each of the following eight excellent varieties, suitable for a first planting:

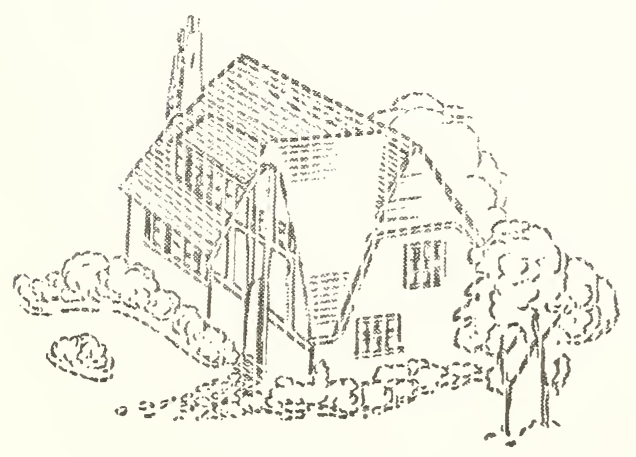

\author{
Baronne de la Tonnaye \\ Bartigon \\ Clara Butt \\ Dream \\ Farncombe Sanders \\ Pride of Haarlem \\ The Sultan \\ Yellow Darwin
}

400 Bulbs in all for $\$ 12.50$ 


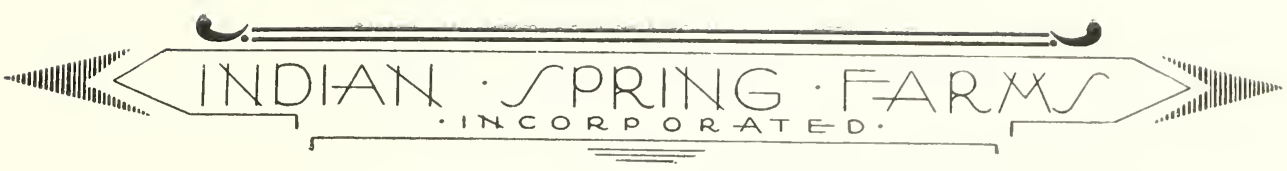

\section{Breeder Tulips}

Breeders are the unbroken or self-colored forms of the old Florist Tulips. The present appreciation of artistic colors has once more brought these old varieties into prominence, and they are now looked upon as the aristocrats of the Tulip race. In them we find wonderful color combinations mostly done in the subdued shades of purples and bronzes, grays and lilacs, yellows and coppers and browns and orange. The flowers are very large and of perfect, globular form, with petals of enduring substance.

Archeron. A very large flower of dull, dark red, borne on tall

Doz. $\quad 100$

stems. 30 inches

$\$ .90 \$ 7.00$

Apricot. A magnificent Breeder of light bronze tones, overlaid with rose; base olive. A large flower of heavy substance well supported on tall, strong stems. 28 inches

Bacchus. A large and very fine flower of rich violet blue, overlaid with a flush of deep plum purple, held erect on sturdy stems. 30 inches

Bronze Queen. Syn. Clio and Biscuit. The charm of the Breeders is well typified in this beautiful variety. The color is soft buff, with a blending of deep yellow and brown and a touch of rose. Not a large flower but very distinct and lovely. 28 inches

Cardinal Manning. Very large, egg-shaped flower with a curious, blended coloring that is lovely. The ground color is soft bishop's purple, overlaid with rosy bronze, changing to almost pure orange at the edges of the petals. 34 inches. .

Chestnut. Rich, dark purplish-maroon flower of medium size and fine form. Reliable and beautiful. 28 inches . . . . .

Copernicus. Dark coppery bronze, flushed old rose; interior warm brown, with yellow base. A splendid large flower and sweet scented. 27 inches

Don Pedro. One of the most distinct and beautiful Breeders. The large flowers are deep coffee-brown, on a cadmiumyellow ground, and flushed with maroon; interior dark reddish mahogany, with base streaked olive. Fragrant. 28 inches

Fairy. Syn. Panorama. Deep orange red, shaded mahogany.

A large flower and very desirable. 26 inches $. . \cdot . \cdot \cdot$.
Godet Parfait. A large flower of rich deep reddish violet. The inside is a shade lighter and brighter than the outside, affording a pleasing blending of tones. Stems tall and graceful. 28 inches

Jaune D'Oeuf. Syn. Sunrise. Large, well-formed flower on a tall stem. Bright, deep lemon-chrome, with a flush of light purple on the outer face of the petals; base pale green. Effective in contrast with the darker varieties. 28 inches.

Klopstock. Beautiful lavender, with shadings of dark helio- 


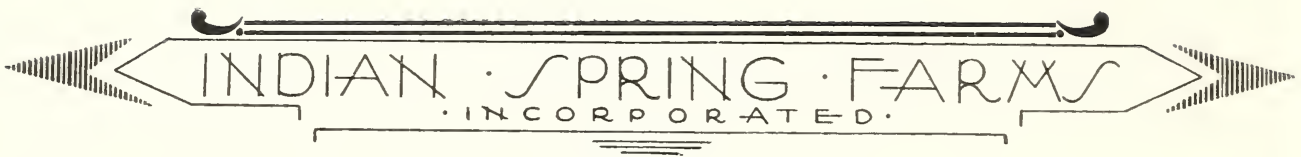

Lord Byron. Very large flower of long form with very pointed Doz. 100 petals. Dark crimson, overlaid with a flush of rose and tinted with blue at the base of the outer petals. Distinct in form and color. 28 inches

Louis XIV. Truly a royal Tulip. An immense flower on a vigorous plant with tall stems. Rich, dull, bluish violet, blended to a broad margin of tawny brown. The color effect is lovely and the blooms are delightfully fragrant. 32 inches

Mabel. Deep rose pink, with a white flush through the center of the petals; white base. A fine flower of unusually clear coloring. 28 inches

Medea. One of the very largest Tulips. Deep salmon-scarlet, with a flush of heliotrope. 28 inches

Plutarchus. A pleasing shade of bronze, flushed with deep rose pink

Turenne. Syn. MacMahon. Fine, large, egg-shaped flower of dull blue violet, intensifying with age

Yellow Perfection. Light bronze-yellow, edged with deeper golden yellow. A variety of unusual beauty. 26 inches . .

\section{Special Breeder Tulip Mixture}

For mass plantings and for cutting gardens where named varieties are not essential, we recommend this special mixture. It includes a wide range of the best Breeder varieties and is sure to give satisfaction. 75 cts. per doz.; $\$ \mathbf{5 . 0 0}$ for $100 ; \$ 10.00$ for $250 ; \$ 38.00$ for 1000 .

\section{Parrot Tulips}

These gorgeously colored flowers are the most striking of all the Tulip race. Their billiant hues and their curiously fringed or laciniated petals, forming blooms of parrot-like form that never fail to attract the admiration of all who see them. The colorings are unique, and they are desirable both for garden plantings and for cut-flowers. Average height 15 inches.

\section{Doz. $\quad 100$}

Admiral de Constantinople. Scarlet, shaded orange $\quad . \quad$. $\$ .75 \$ 5.00$

Cafe Brun. Yellow, striped and feathered reddish-brown $\quad . \quad \begin{array}{rr}\mathbf{7 5} & \mathbf{5 . 0 0}\end{array}$

Cramoisie Brilliant. Rich blood-crimson, with blackish markings . . . . . . . . . . . . . . . . . .75

Lutea Major. Very large, clear bright yellow . . . . . . . $\quad .75 \quad 5.00$

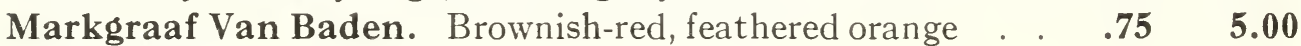

\section{Special Parrot Tulip Mixture}

For those who want a planting of these interesting Parrot Tulips and do not care for the varieties separately named, we offer the better kinds in a mixture. 70 cts. per doz.; $\$ 4.50$ for 100 


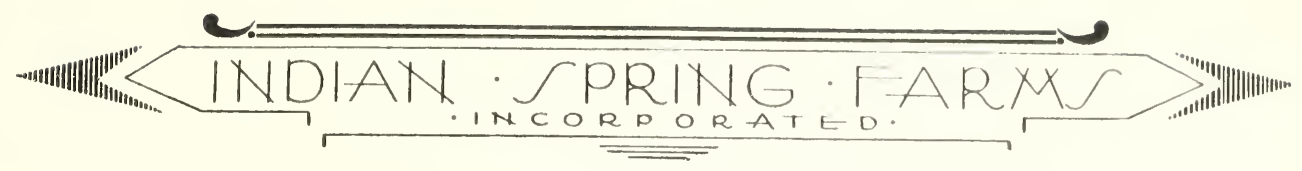

\section{Lily Flowering Tulips}

This is an artistic class of Tulips resulting from a cross between the pointed petaled Tulipa Retroflexa and the Darwins. The flowers are long, with gracefully pointed and recurved petals that open in the typical Lily form.

Adonis. A bright rose pink, or rosy red, one of the most de- Doz. 100

lightful pinks in tulips. A flower of long and graceful form.

20 inches............... \$1.50

$\$ 11.00$

Artemis. A lovely flower of deep, clear rose pink, with a white base, that comes gracefully poised on long, slender stems.

Charming in both habits and color . . . . . . . 1.50

Sirene. A beautiful flower with the same soft pink tones as

Clara Butt. One of the best of this group. 20 inches

1.25

\section{Bunch Flowering Tulips}

This new and novel Tulip comes with several flowers on a stem. They are very showy and beautiful.

Monsieur le Mottet. Creamy white; usually coming three to Doz. $\quad 100$

five flowers on a stem

$\$ 12.00$

\section{How to Plant Tulips}

Tulips of all kinds should be planted after the leaves on the trees begin to drop in the fall. October or November are the best months.

The ground should be prepared well in advance. Dig the soil deeplyeighteen inches if possible-and pulverize fine. Do not plant where the drainage is poor or where water stands during any part of the year. Do not use barnyard manure unless it can be spaded in the ground the spring before bulbs are to be planted. Bonemeal is the only safe fertilizer to use about Tulips, and it should be mixed with the soil freely.

Set the bulbs 4 to 8 inches apart in rows or in groups. Plant early tulips 4 to 5 inches deep, and the larger late varieties 5 to 6 inches below the level of the ground. In heavy soils, a little sand under the bulb to insure drainage is beneficial. Always see that the bulb is firmly imbedded in the soil and not left hanging in the hole with an air space beneath.

After planting, mulch the beds lightly with leaves or clean straw as a protection against heaving by the frosts. The mulch should be carefully removed when spring growth starts.

Tulips may be dug each season, if desired, as soon after the blooming season as the tips of the leaves begin to die back, or they may be left in the ground two or more years, until they become crowded and throw small blooms.

Store the bulbs in a cool, dry place during the summer months and replant again in a new location in the fall. 


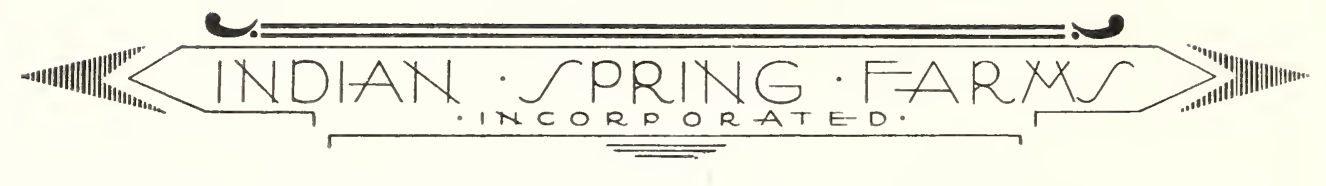

\section{Hardy Lilies}

There is no genus of plants better fitted for any garden than the Lily. They can truly be called the noblest of garden flowers. Their conspicuous blooms, striking colors, and stately forms appeal to the eye, and their delightful fragrance is most pleasing.

The Lilies here offered are easy to grow, perfectly hardy, and will do well in any garden. Our bulbs are grown on our own farms in our rigorous Northern climate and are the best obtainable.

Order now for freshly dug bulbs to be shipped prepaid in October.

\section{How to Grow Lilies}

Select a well drained location for your Lily planting. The ground should be prepared well in advance by digging deep, 16 inches or more. If drainage is not perfect, arrange for drainage by an underbed of stones or porous materials. On top of this should be at least 2 feet of good loam mixed with leaf-mold and sand in liberal proportions. If fertilization is necessary, use bone-meal. Do not use stable manure of any kind. In their natural state, Lilies thrive in what might be termed "poor soil," and they should not be over fertilized. Plant Lily bulbs deep so they will be covered with a depth of soil at least twice the diameter of the bulbs-eight to ten inches is not too deep. They should not be planted alone but do better where there is a protective ground-cover and where they are not subjected to frequent cultivation. Most Lilies may be planted in either spring or fall. They are best planted when fresh dug bulbs are obtainable.

LILIUM REGALE (Regal Lily). Without question this wonderful, new, hardy Lily from China is the most satisfactory white Lily grown in our American gardens. Discovered growing wild in the poor volcanic soil high up in the mountains by Mr. E. H. Wilson of the Arnold Arboretum, Boston, it has readily adapted itself to cultivation, and is fast replacing all older varieties for garden planting and for florists' forcing. The flowers are large and trumpetshaped, ivory-white, shaded pink and tinged yellow at the base of the petals. They open in July in clusters of two to six or more on rigid stems 2 to 4 feet high. In favorable locations, they reach a height of 6 feet and produce flowers of immense size and wondrous beauty.

Small Bulbs, blooming size, 25 cts. each; 65 cts. for $3 ; \$ 2.50$ per doz. Large Bulbs, 50 cts. each; $\$ 1.35$ for $3 ; \$ 5.00$ per doz. Mammoth Bulbs, selected, 75 cts. each; $\$ 2.00$ for $3 ; \$ 7.50$ per doz.

L. TIGRINUM SPLENDENS (Giant Tiger Lily). This improved form of the native single Tiger Lily is of tall, imposing growth, reaching a height of 4 to 6 feet. The latest of all the Lilies, blooming in late August and September. The large flowers are orange-red, richly spotted purple on reflexed petals, and are borne on long, well spaced panicles on the stiff stems. Extra large bulbs, 35 cts. each; 90 cts. for $3 ; \$ 3.00$ per doz.

L. UMBELLATUM (Western Orange-cup Lily). A thoroughly hardy Lily that is desirable for its bright color early in the season. The trumpetshaped flowers are dark orange-red and are borne in clusters on strong stems of 3 feet. Open with the Peonies in June.

Extra large bulbs, 35 cts. each; 85 cts. for $3 ; \$ 2.50$ per doz. 


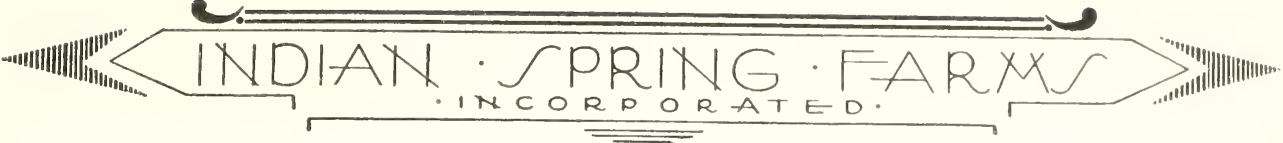

\section{Lily of The Valley}

LILY OF THE VALLEY (Convallaria Majalis). This delightful flower of the old-fashioned garden thrives best in a shady, moist location and when once planted needs but little attention. The delicate little bell-shaped flowers, arranged on comparatively long spikes, rarely stand over 9 inches high, and are pleasingly fragrant. For outdoor plantings, clumps of a dozen or more pips are most satisfactory and give quicker effect.

Large clumps, 65 cts. each; $\$ 1.50$ for 3

\section{Hemerocallis (Yellow Day Lily)}

HEMEROGALLIS FULVA. The Brown Day Lily. This popular hardy plant has long been a favorite in our gardens, and is useful in filling in difficult places under trees and shady corners. The flowers are coppery orange, with a shade of crimson, and are borne in profusion in July on tall, slender stems 3 feet high. The tall, graceful, grass-like foliage is very decorative, and is particularly effective when massed along streams or on moist banks, where it sets off the colorful blooms in charming contrast.

Strong plants, 35 cts. each; $\$ 1.00$ for $3 ; \$ 2.50$ per doz.

\section{Hardy Phlox}

The Perennial Phlox might well be called the flower of summer. Blooming as they do at the between-season time when spring has past and before the fall flowers come, they fill in the border plantings and furnish color during the trying months of July and August when all else fails. The fragrant flowers cover a wide range of colors, and are borne in huge heads, or trusses, on stout stems above a bank of rich green foliage. Their desirable habits and massive blooms afford many possibilities for mass plantings and garden effects. By clipping off the bloom trusses before they go to seed, a second crop of flowers may be had which will often prolong their season late into the fall and until the frosts come.

CULTURE. Phlox are gross feeders and are at their best in a rich soil and where they do not lack for moisture during the bloom season. Plant in the full sun if possible, but they will do well in partial shade, provided they are not robbed by roots of the trees or shrubbery. Set eighteen inches to two feet apart and cultivate frequently. Destroy all chance seedlings that may appear, as they revert to the old magenta types and may eventually choke out your parent plants. Divide the old clumps and reset every third year, or replace with new roots, if you would have strong, thrifty plants.

\section{General List of Phlox}

ALBION. White, faintly marked mallow-purple at the eye. Florets large with the segments overlapping. Trusses large and flat, borne on stalks 27 inches tall. Midseason.

35 cts. each; 90 cts. for $3 ; \$ 3.00$ per doz.

AUSTRALIA. Rich rhodamine-purple, shading to an indistinct amaranthpurple eye. Florets large with segments separately spaced. Medium tall with loosely formed trusses of medium size. 36 inches. Late.

35 cts. each; $\$ 1.00$ for $3 ; \$ 3.00$ per doz. 


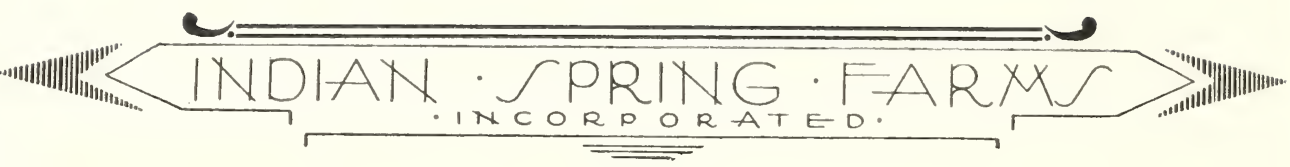

BRIDESMAID. A beautiful variety with large, rounded trusses of perfect form. White, delicately flushed pale amaranth-pink and blending to a large center of bright Tyrian rose. 36 inches. Midseason.

35 cts. each; $\$ 1.00$ for $3 ; \$ 3.00$ per doz.

COQUELICOT. Medium sized florets, bright scarlet-red, blending to amaranth-purple at the eye. Trusses large and loosely spreading. 30 inches. Midseason. A clear, brilliant color that does not fade.

50 cts. each; $\$ 1.25$ for $3 ; \$ 4.00$ per doz.

ELIZABETH CAMPBELL. A handsome variety in every way and the best of the light pinks. The florets are very large and evenly rounded with broad, overlapping segments. The color is clear, bright rose-pink suffused on a white ground, shading to clear white at the center. Trusses are medium size and conical in form. Foliage rich, dark green. 24 inches. Midseason.

50 cts. each; $\$ 1.35$ for $3 ; \$ 4.00$ per doz.

ENCHANTRESS. A beautiful variety similar to Elizabeth Campbell but more vigorous in growth and having a dark center instead of white. The florets are very large and round with broad segments that overlap. Soft rose-pink, overlaid with rose-red toward the borders, surrounding a center of Tyrian-pink. Trusses large. 30 to 36 inches. Late midseason.

50 cts. each; $\$ 1.35$ for $3 ; \$ 4.00$ per doz.

ETNA. Bright scarlet-red with a small amaranth-purple eye. Florets small to medium with close set segments. Semi-dwarf growth, 18 to 24 inches, with large, loose trusses.

35 cts. each; 90 cts. for $3 ; \$ 2.75$ per doz.

EUROPE. A strong, sturdy and distinct variety with large, evenly formed trusses. The florets are large with segments slightly overlapping. Pure white with a distinct bright a maranth-purple eye. Midseason.

30 cts. each; 75 cts. for $3 ; \$ 2.75$ per doz.

FERDINAND CORTEZ. Very large florets of bright Tyrian-rose, flushed deeper at the borders and shading lighter Tyrian-pink around the deeper amaranth-purple eye. Heavy, branched trusses; rich, dark green foliage. 24 to 27 inches. Midseason. Similar to Sir Edwin Landseer but with larger florets and slightly deeper color tone.

\section{0 cts. each; $\$ 1.00$ for $3 ; \$ 3.50$ per doz.}

FRAULEIN VON LASSBURG. Pure white. Florets medium size with round segments overlapping. Fine large trusses. Medium height. Midseason.

35 cts. each; 90 cts. for $3 ; \$ 3.00$ per doz.

ISABEY. A tall variety with loose and widely branched trusses. Medium to small florets of soft rose-red, shading lighter around a distinct a maranthpurple eye. Similar in color to R. P. Struthers but has smaller florets and distinctly different growth.

35 cts. each; 90 cts. for $3 ; \$ 2.75$ per doz.

LA VAGUE. Very tall, 36 to 40 inches, with large, conical trusses of fine form. Florets medium size with segments overlapping. Soft amaranth-pink, shadinglighter, with a conspicuous eye of bright Tyrian-rose. The strong lilac color and the profusion of bloom make this a very desirable variety.

30 cts. each; 75 cts. for $3 ; \$ 2.50$ per doz. 


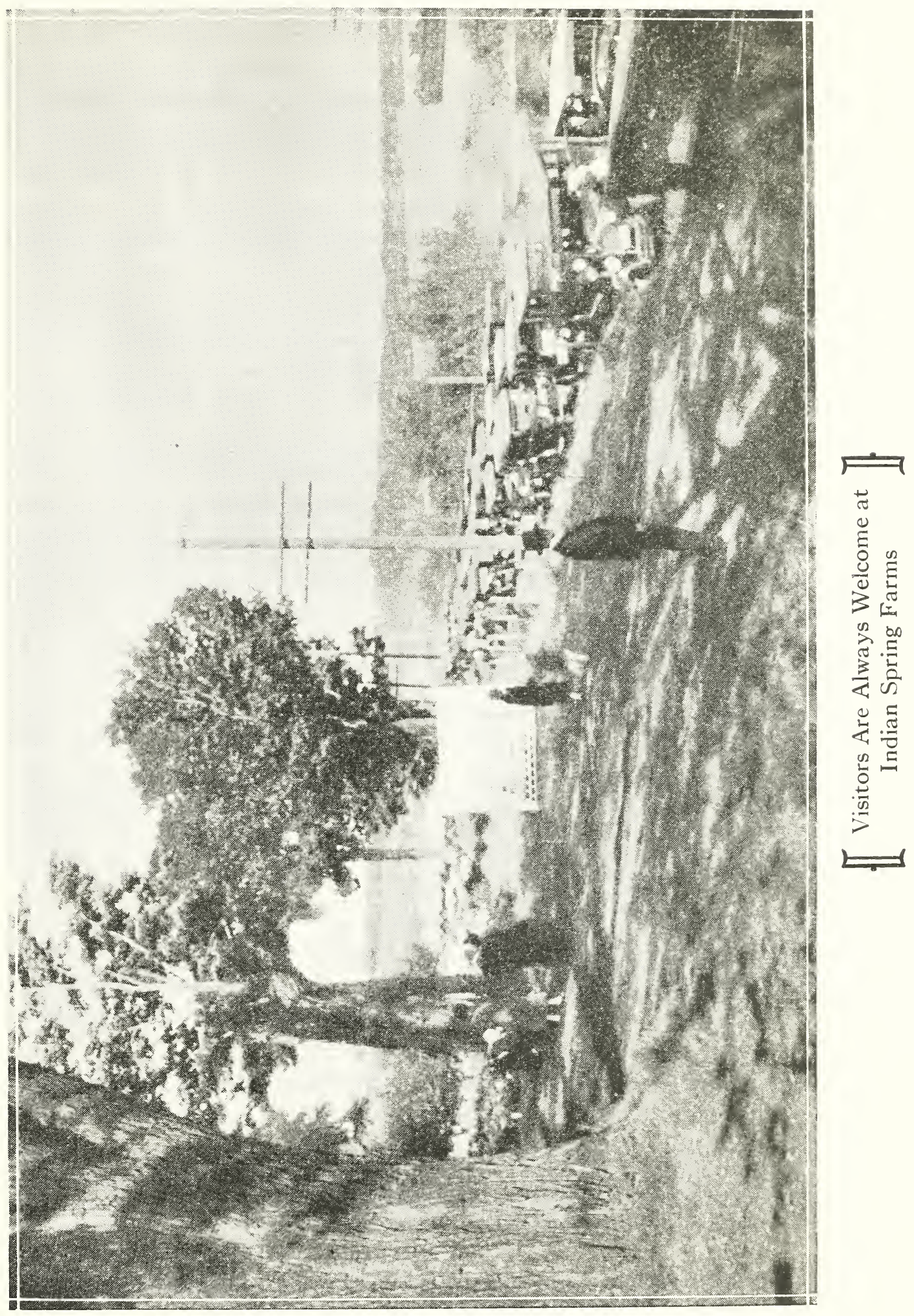




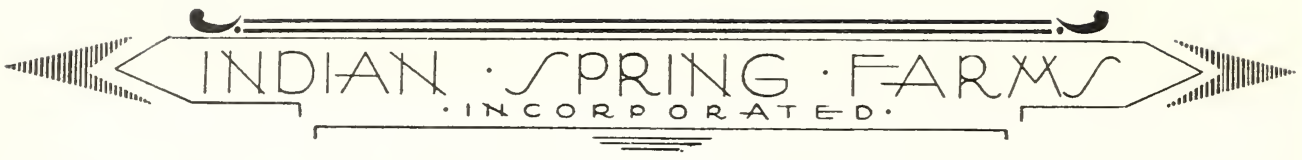

LE SOLEIL. Soft, deep rose-pink, shading lighter at the center, with faint amaranth-purple markings at the eye. The large florets with overlapping segments are borne in very compact trusses. Dwarf to medium height. 18 to 24 inches.

35 cts. each; $\$ 1.00$ for $3 ; \$ 3.00$ per doz.

LOTHAIR. Small, rounded florets with overlapping segments. Uniform Tyrian-rose with a distinct eye of amaranth-purple. A tall, strong grower. A good "red" variety for landscape effect.

30 cts. each; 75 cts. for $3 ; \$ 2.50$ per doz.

LUMINEUX. Medium to large florets with spaced segments. Soft Tyrianpink, shading lighter to pale amaranth around a small Tyrian-rose eye. Medium height with globular, compact trusses.

30 cts. each; 75 cts. for $3 ; \$ 2.50$ per doz.

MME. PROSPER LANGIER. A fine, dark red variety. The florets are medium size with the segments partially overlapping. Uniform bright aster-purple, shading to pomegranate-purple at the eye.

35 cts. each; $\$ 1.00$ for $3 ; \$ 3.00$ per doz.

MICHAEL BUCHNER. Medium sized florets with overlapping segments. Dull mallow-purple, with a star-shaped center of light pomegranate-purple. a good deep lavender variety. 30 cts. each; 75 cts. for $3 ; \$ 2.50$ per doz.

MISS LINGARD. One of the earliest flowering tall varieties belonging to the Suffructicosa group and one of the most satisfactory to grow because of its pleasing light green foliage that is free from attacks of red spider. The florets of medium size have the segments slightly overlapping and are pure white with a faint tint of rose-pink about the eye. Long, compact trusses. Height 30 inches.

35 cts. each; 85 cts. for $3 ; \$ 2.75$ per doz.

MISS MILLY VON HOBOKEN. This variety has the largest individual florets of any Phlox in our collection. They are evenly rounded with segments spaced. The color is a soft deep rose-pink, blended to Tyrian-rose about the eye. Compact, flat trusses of medium size on stems of 24 to 27 inches. Midseason to late. 50 cts. each; $\$ 1.25$ for $3 ; \mathbf{\$ 4 . 0 0}$ per doz.

MRS. CHARLES DORR. Tall growing variety with long, compact, globular trusses. Individual florets small with spaced segments. Color clear light mallow-purple, shading to mallow-pink, with faint star markings of Tyrian-pink at the center. A desirable lavender for landscape effect. 36 to 40 inches.

35 cts. each; $\$ 1.00$ for $3 ; \$ 3.00$ per doz.

MRS. JENKINS. A very free flowering early variety producing large trusses of clear, pure white flowers. The individual florets are large with segments overlapping. 27 inches. $\quad 30$ cts each; 75 cts. for $3 ; \mathbf{\$ 2 . 5 0}$ per doz.

RIJNSTROOM. A very beautiful variety of brilliant pink color, vigorous in growth, with heavy trusses. The florets are large and rounded, with overlapping segments, bright rose color lighted with a flush of rose-red, blending to amaranth-pink at the center. 30 inches.

35 cts. each; $\$ 1.00$ for $3 ; \$ 3.00$ per doz.

R. P. STRUTHERS. The large round florets are soft, light rose-red surrounding a distinct amaranth-purple eye. Large trusses of loose form. 24 to 27 inches. Lighter in color than Sir Edwin Landseer.

35 cts. each; 85 cts. for $3 ; \$ 2.50$ per doz. 


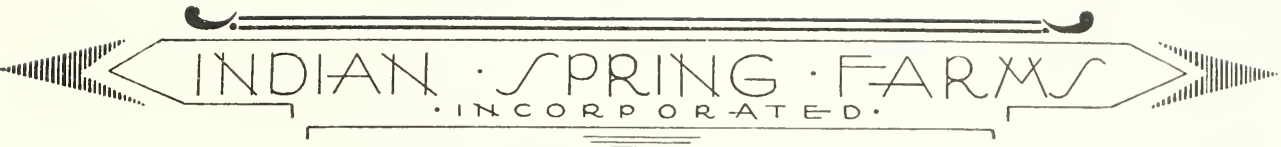

SIR EDWIN LANDSEER. A good, tall growing red that is effective for landscape planting. Large, conical trusses with individual florets medium to large, rounded, with close set segments. The color is uniform Tyrianrose, slightly shaded lighter rose around the eye of amaranth-purple. 30 inches.

35 cts. each; $\$ 1.00$ for $3 ; \$ 3.00$ per doz.

SUNSET. Large, loose trusses of small, uniform, round florets with overlapping segments. A pleasing shade of bright Tyrian-pink, shading to an inconspicuous eye of darker Tyrian-rose. 24 to 27 inches.

30 cts. each; 75 cts. for $3 ; \$ 2.50$ per doz.

THOR. A splendid Phlox of bright and pleasing color. The large florets, with segments slightly overlapping, are bright rose color, flushed rose-red, with a distinct eye of Tyrian-rose. Large, compact trusses on stems 24 to 27 inches high. Late. 35 cts. each; 85 cts. for $3 ; \$ 2.50$ per doz.

\section{The "Choice Ten" Phlox Collection}

These ten good varieties will make a beautiful show of bloom throughout the summer when other flowers are lacking.

Elizabeth Campbell. Light pink . . . . . . . . . . . . . . . \$.50

Europe. White with red eye . . . . . . . . . . . . . . . . 30

La Vague. Lilac with red eye . . . . . . . . . . . . . . . . . 30

Lothair. Salmon-red with carmine eye . . . . . . . . . . . . . $\quad .30$

Michael Buchner. Deep lavender . . . . . . . . . . . . . . . 30

Miss Lingard. Finest white . . . . . . . . . . . . . . . . . . ${ }_{35}$

Miss Milly von Hoboken. Soft pink . . . . . . . . . . . . . . $\quad .50$

Mrs. Jenkins. Clear white . . . . . . . . . . . . . . . . . . 30

Sir Edwin Landseer. Rosy-red . . . . . . . . . . . . . . . . $\quad .35$

Sunset. Dark rosy-pink . . . . . . . . . . . . . . . . . . . . $\frac{.30}{\$ 3}$

Total $\$ 3.50$

This "Choice Ten" Phlox Collection, $\$ 3.00$

PHLOX OFFER "A". Twenty fine named Phlox, our selection of varieties from our catalog list, each separately labeled, in a good range of colors, for $\$ 5.00$ 


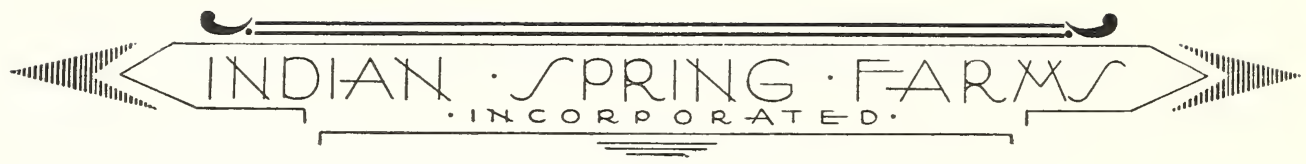

\section{Business Terms and Information}

\section{Please Read Carefully Before Ordering}

Terms. Full remittances should accompany all orders, unless satisfactory credit arrangements have been previously arranged.

C.O.D. shipments frequently cause delay in delivery and result in consequent damage to plants and loss to ourselves or to our customers. We will only ship C.O.D. on special request and when 25 per cent of the amount of the order is paid in advance.

Retail prices are net. We prepay transportation charges on all retail orders paid for before shipment, but not ot herwise. Special quantity prices to the trade quoted on special request. Early orders to reserve stock and shipping preference may be paid 10 per cent with order and balance before September 1.

Strict compliance with these terms will save correspondence at shipping time and consequent delay in deliveries.

How to Order. To avoid delay, use the order sheet received with this catalogue. Write, or print your name very plainly, exactly as it should appear on the label of your shipment.

Order as early as possible for later shipment to be sure of getting all the varieties wanted.

Acknowledgments. You will receive from us a prompt acknowledgment of your order-a yellow sheet, showing all items exactly as we have them recorded for shipment, the total amount of the order and the amount of your remittance received. If this is not correct in every detail, or if you wish any changes or additions made, please notify us at once. If for any reason we are unable to fill any item on your order with good stock, you will be promptly notified, and that part of your money paid will be refunded.

Transportation. We prepay transportation charges on all orders paid for in advance to all points within the United States, shipment by parcel post or express at our discretion. Orders sold at wholesale, or on special quotations, will be shipped collect. Transportation to foreign countries must be paid by the purchaser.

How to Remit. Make remittances by Post Office Money Order, Bank Draft, or by Personal Check, payable to Indian Spring Farms, Inc., and not to individuals. Do not send currency or silver except by registered letter.

Substitutions. No substitutions will be made unless your order so requests. With your permission, we are glad to send as a substitute a similar variety of equal or higher value, when possible, for any item we are unable to fill.

Shipments. Peony shipments begin as soon after September 1 as roots are matured, depend. ing on the season. Bulbs, October 1 , or as soon as imports are received. For spring shipment of Peonies, see page 9.

Advance orders will be filled as far as possible in rotation as received, and have precedence over later orders. As we start the shipping season with several thousands of advance orders for which it is not possible to prepare stock until growth is mature, it is obvious that late purchasers can not expect immediate shipments.

Size of Roots. See "About Approved Peony Roots," page 9.

Claims. We guaraniee the safe arrival of shipments to all points within the United States, but can not be responsible for losses occurring during transportation on shipments to foreign countries. All claims must be made promptly on receipt of goods.

Guarantee. A.ll plants shipped are guaranteed to be true to name, vigorous and healthy when received. Should any error occur in labeling, or otherwise, and any stock shipped eventually prove untrue, we will replace it with true stock, and you may keep the plants first sent.

\section{What We Do Not Guarantee}

We do not guarantee our plants to grow in your garden. All guarantee ceases when shipments reach the purchaser in good condition, and we assume no responsibility for what may happen to them thereafter. We can not insure the life of plants, and we make no guarantee, expressed or implied, covering their successful culture after they have passed beyond our control. Examine shipment promptly on arrival and report at once any item that is not acceptable. We will gladly make quick and satisfactory adjustment at that time. When shipment is not acceptable on these terms, there is no sale. 
MASON PRINTING CORPORATION SYRACUSE AND NEW YORK 



\section{ORDER FORM \\ INDIAN SPRING FARMS, Inc. BALDWINSVILLE, N. Y.}

\section{Date}

Send to

P. O. Box, Street,

Write Name and Address Plainly or Rural Route

Post Office

Seni by

When

Cash Enclosed \$

VARIETIES

PRICE

AMOUNT 


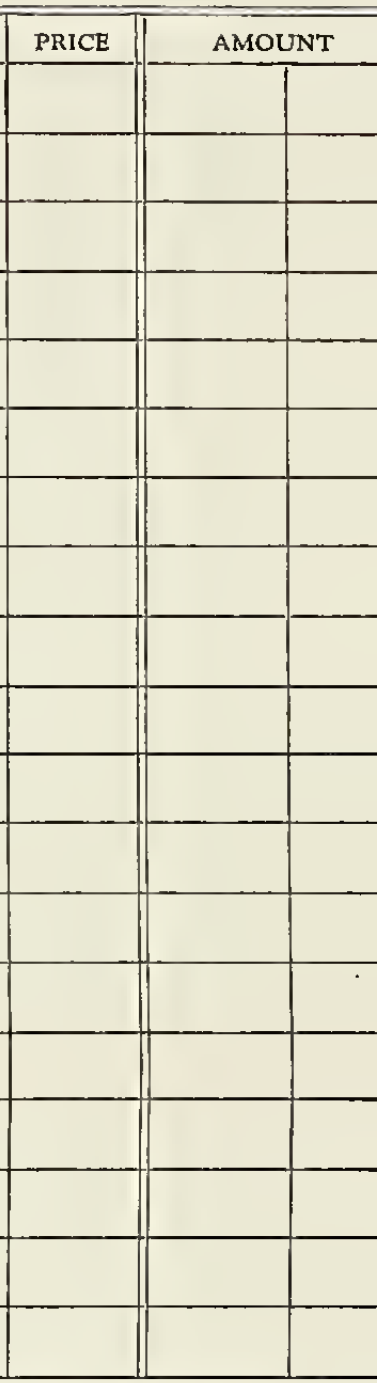

Shall we substitute, if for any reason we cannot deliver a variety as ordered. A REQUEST:- We shall esteem it a great favor if you will give us beiow the names of your 


\section{INDIAN SPRING FARMS, Inc.}

\section{BALDWINSVILLE,}

NEW YORK 



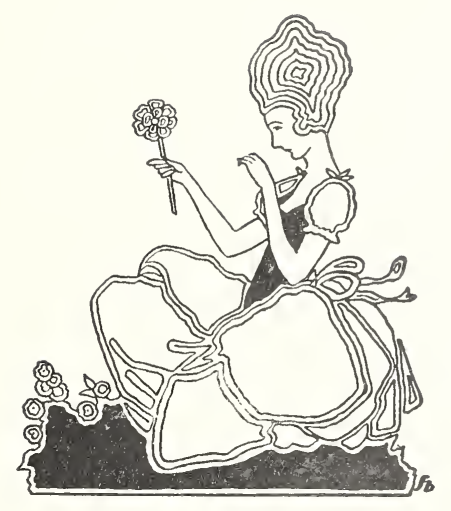

"ONCE. ON A. TIME. LONG yeARS AGO.

WHEN - GRANDMA WAS A. GIRLSSO TINY THEY DID - NOT P PUT ON AIRS WITH ME

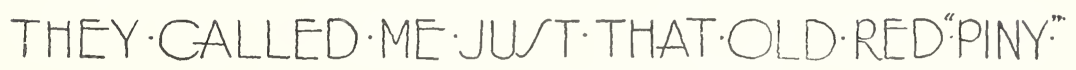

I GREW.BESIDE-THE·RIBBON-GRASS.

AND VERY NEAR THE.BLEEDING HEART.

BUT NOW'A. "PEONY"AM I AND PLAY

A.MOST IMPORTANT PART"

FRANCES CAMPBELL. 

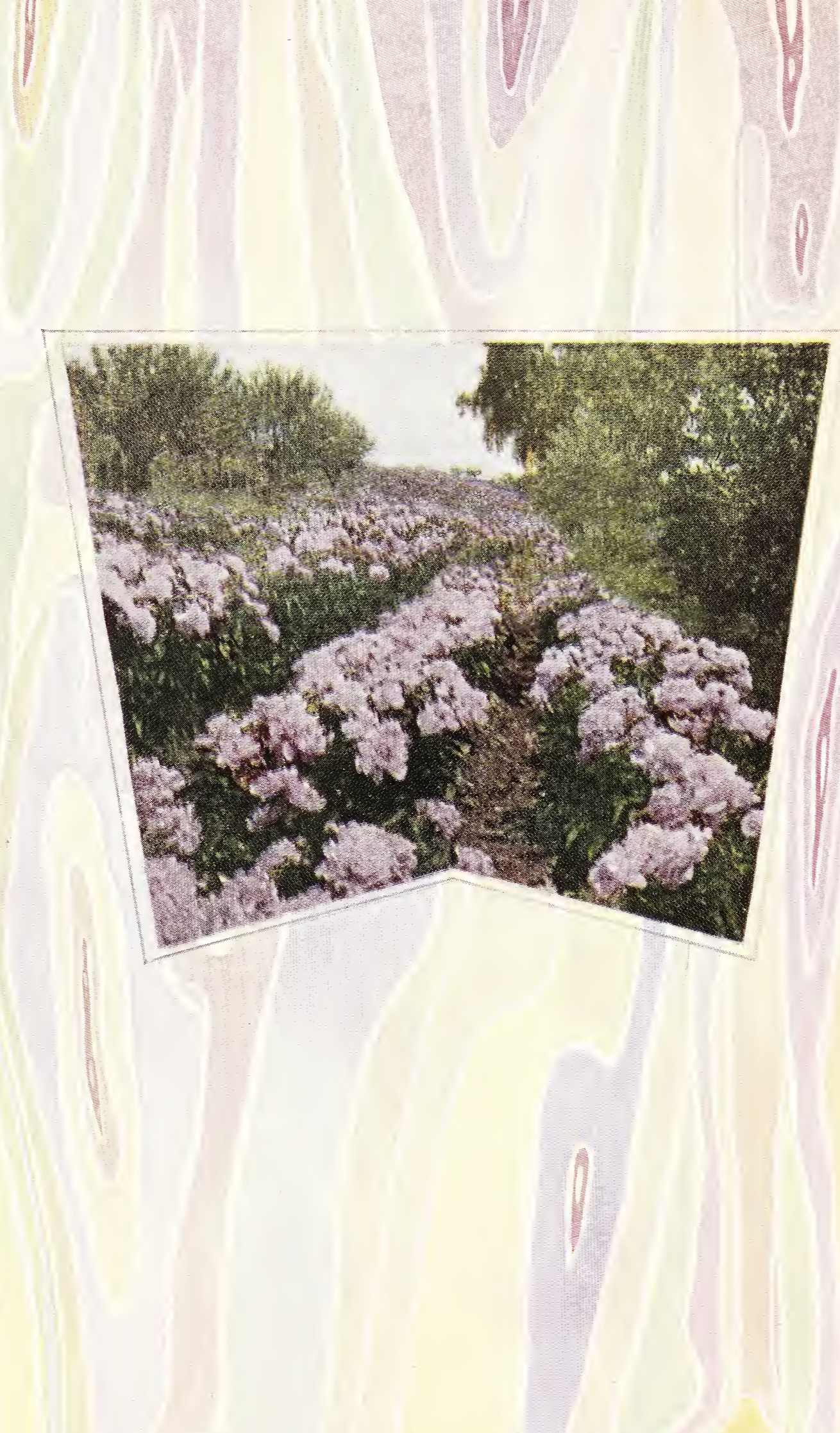